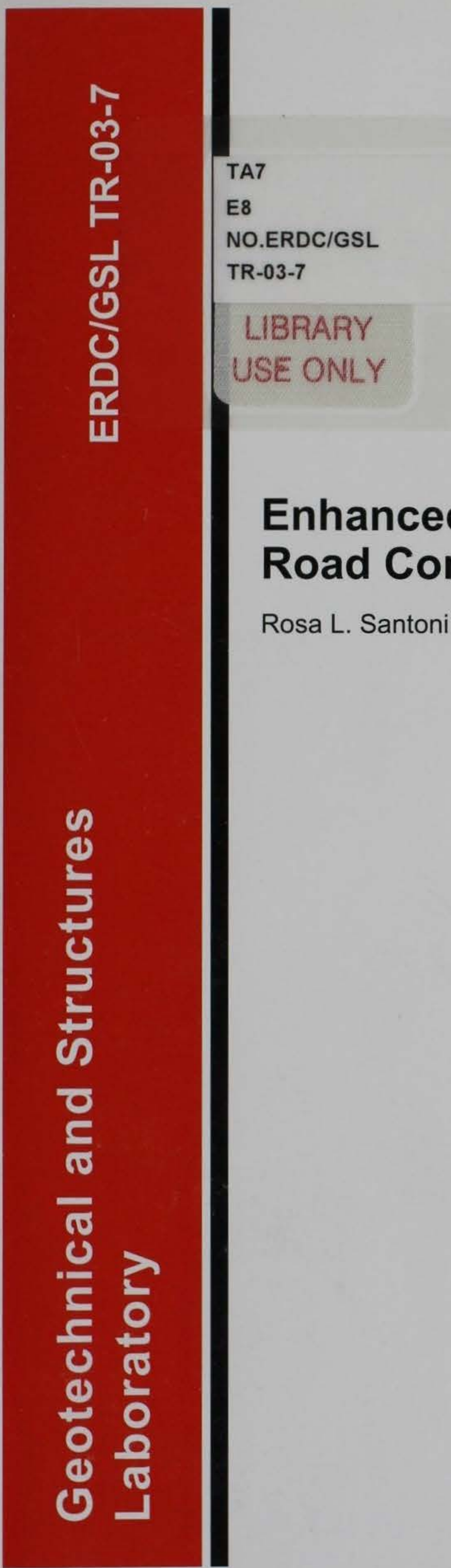

US Army Corps of Engineers ${ }_{\circledast}$

Engineer Research and Development Center

Enhanced Coastal Trafficability: Road Construction Over Sandy Soils

Rosa L. Santoni

July 2003 


\section{CS=CEm $\mathrm{C}$ Property of the Unilod States Government}

\section{Enhanced Coastal Trafficability: Road Construction Over Sandy Soils}

Rosa L. Santoni

Geotechnical and Structures Laboratory

U.S. Army Engineer Research and Development Center 3909 Halls Ferry Road

Vicksburg, MS 39180-6199

Final report

Approved for public release; distribution is unlimited
ERDC/GSL TR-03-7

July 2003

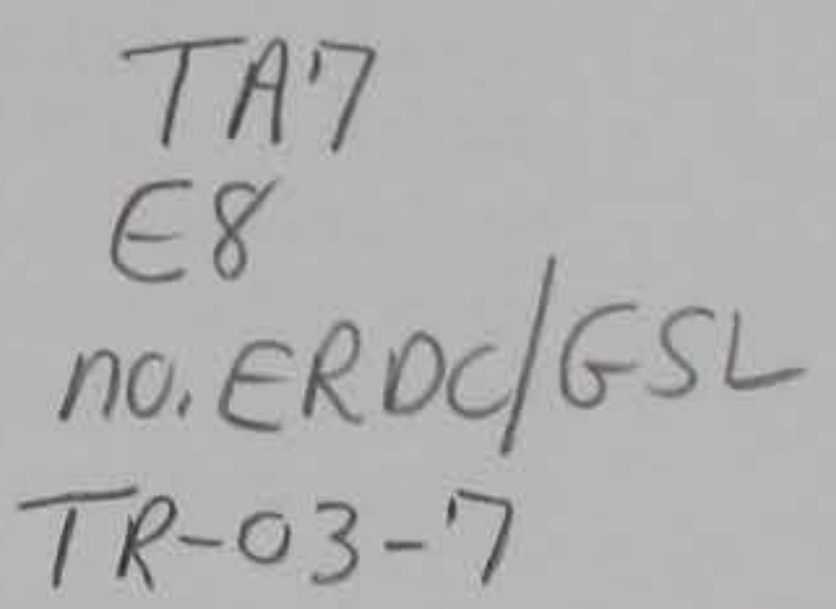




\begin{abstract}
This report describes field experiments conducted using Multi-Purpose (MP) mats, hexagonal plastic mats (Allround and Special), and sand-geofiber stabilization for expedient road construction over sandy soils. Field sections were constructed and trafficked to evaluate construction procedures, design parameters, and their performance over loose sand conditions. Experiment items were trafficked with 500 passes of a 41,600-lb, 5-ton military truck. Field experiment results indicated that MP mats and sand-geofiber stabilization are capable of providing structural support to military traffic over sandy soil conditions on straight and curved sections. The Allround and Special hexagonal plastic mats are capable of withstanding limited traffic, but they are unsuitable for supporting substantial amounts of military traffic on curved sections over the very loose sand conditions used in this experiment.
\end{abstract}

DISCLAIMER: The contents of this report are not to be used for advertising, publication, or promotional purposes. Citation of trade names does not constitute an official endorsement or approval of the use of such commercial products. All product names and trademarks cited are the property of their respective owners. The findings of this report are not to be construed as an official Department of the Army position unless so designated by other authorized documents. 


\section{Contents}

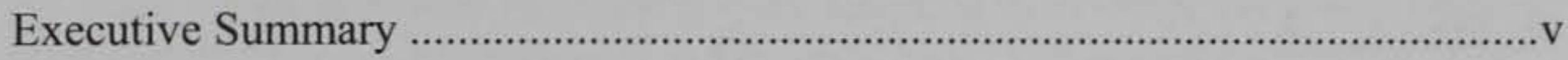

Conversion Factors, Non-SI to SI Units of Measurement.................................. vii

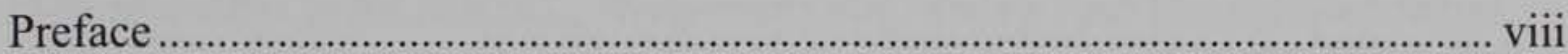

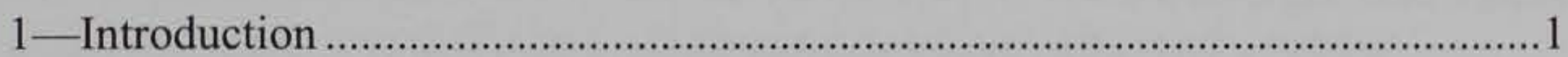

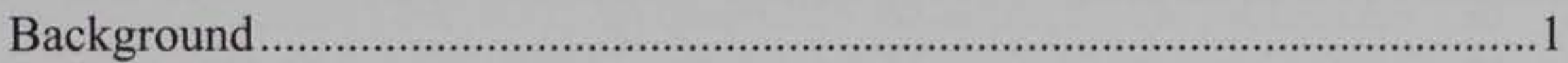

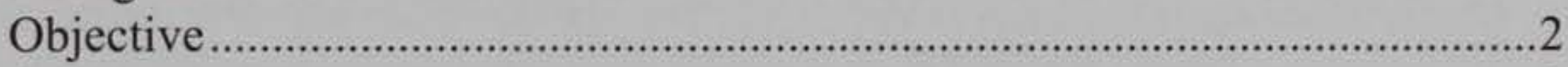

Scope

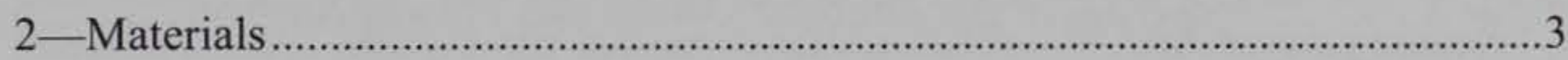

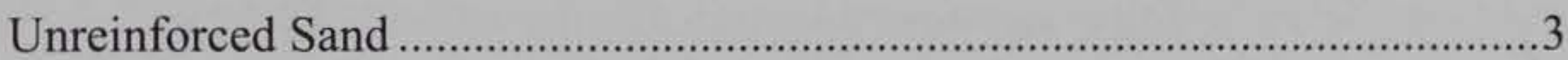

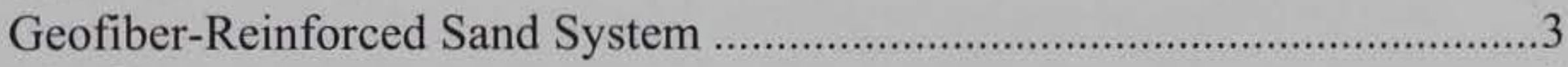

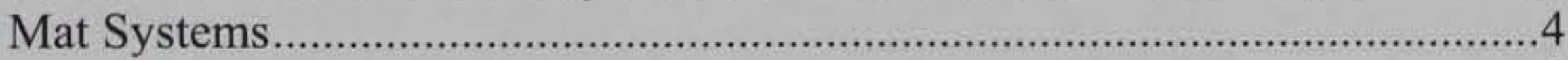

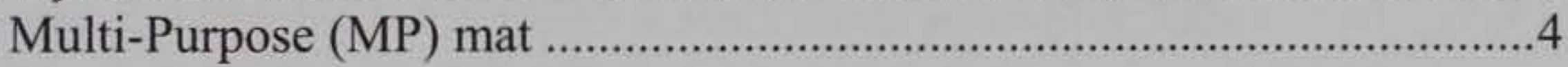

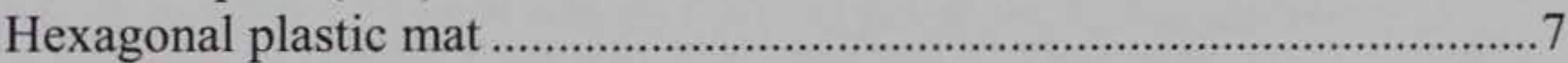

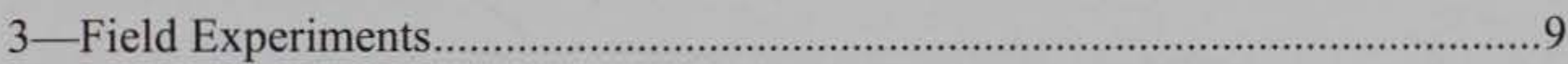

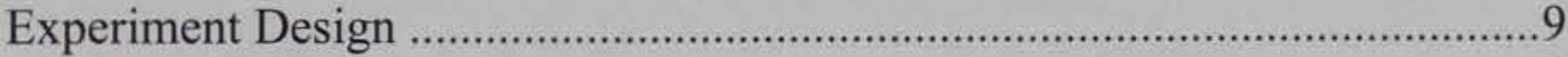

Description …

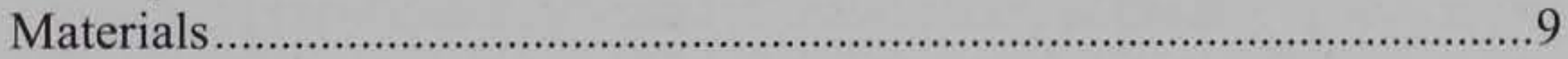

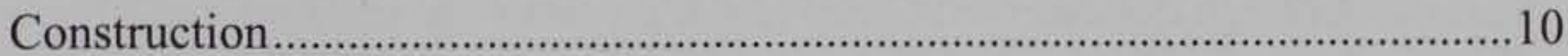

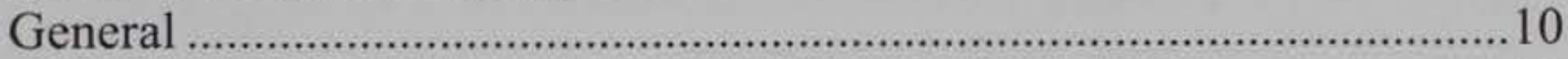

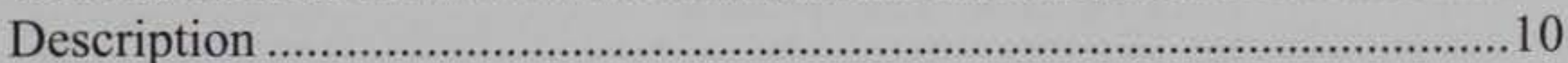

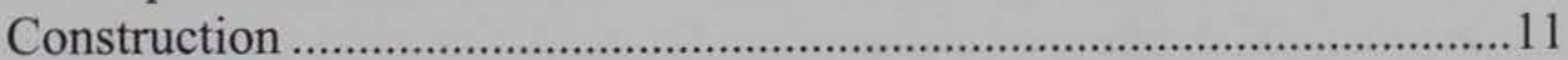

Behavior of Experimental Items Under Traffic ...........................................14

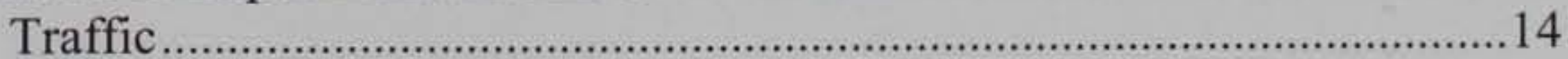

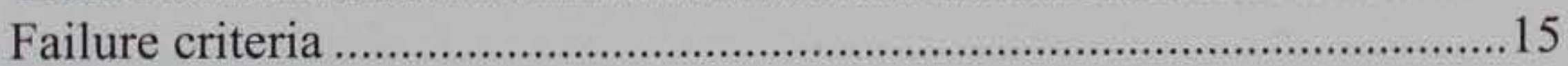

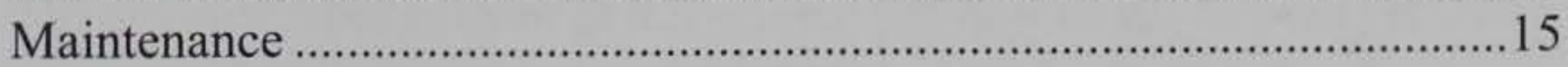

Rut depth measurements .................................................................15

Moisture and density measurements ....................................................16

Dynamic cone penetrometer (DCP) measurements................................16

Cross section measurements...............................................................17

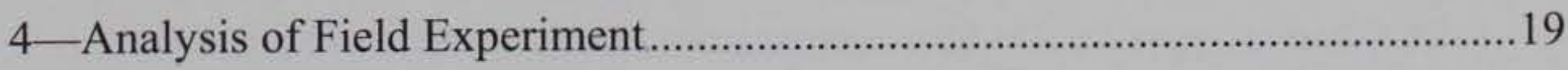

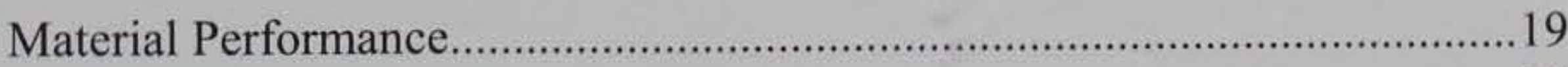

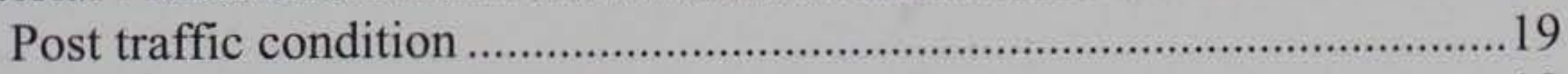

Item 1: Multi-Purpose Mats .............................................................19

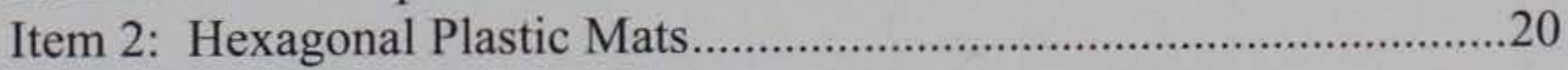


Item 3: Sand-Geofiber Stabilized Sections................................................21

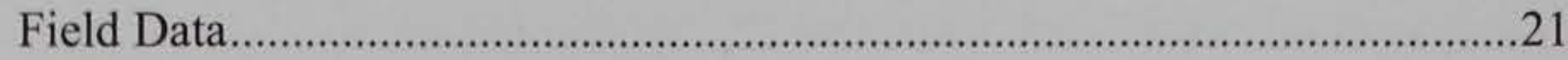

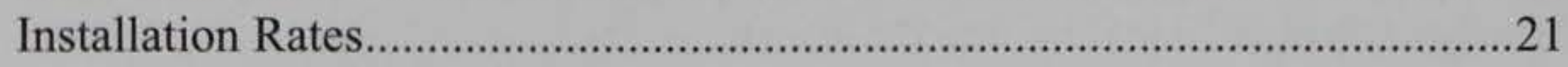

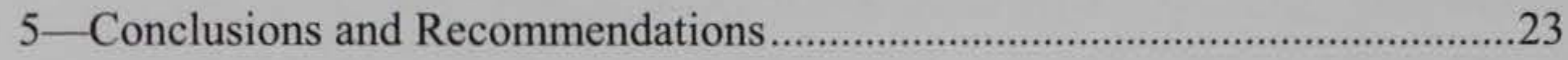

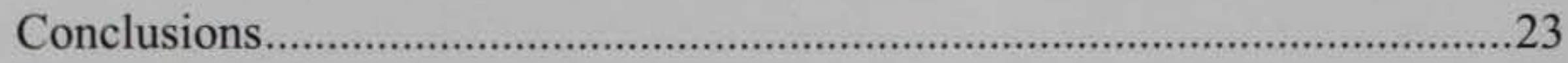

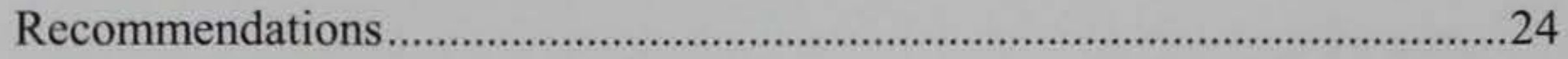

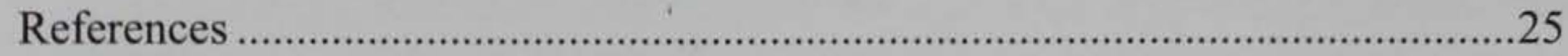

Figures 1-29

Photos 1-94

SF 298

\section{List of Tables}

Table 1. Sand Properties............................................................................

Table 2. Properties of the Aluminum Connector Pin and Anchors .............6

Table 3. MP Mat and Pin Connector Results (Modified ASTM

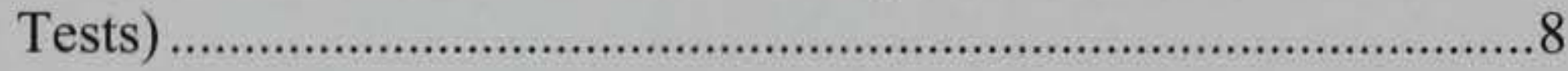

Table 4. MP Mat and Pin Connector Results (ASTM Tests) ………….......8

Table 5. Summary of the Rut Depth Measurements ..................................16

Table 6. Summary of Moisture and Density Measurements ......................17

Table 7. DCP Results Summary for the Full-Scaled Field Test

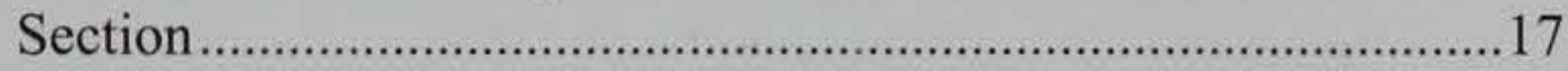

Table 8. Permanent Deformation Measurement for the FullScaled Field Test Section ................................................................18

Table 9. Performance Summary ……………………………………..... 


\section{Executive Summary}

This report describes an investigation designed to evaluate various expedient road construction techniques over sandy soils under full-scaled test traffic. The investigation was conducted at the U.S. Army Engineer Research and Development Center (ERDC), Vicksburg, MS, during June through December 2001. The objectives of this investigation were to (a) evaluate the performance of the multi-purpose (MP) mat, hexagonal plastic mat, and sand-geofiber stabilization on curved sections; (b) determine the construction procedures and construction rates for each system; and (c) prepare expedient road construction guidelines that will support military operations such as the Joint-Logistics-OverThe-Shore (JLOTS). Traffic was applied to the mat sections and the sandgeofiber section with a 5-ton military truck loaded to a 41,600-lb gross vehicle weight. ${ }^{1}$ The wheeled military traffic testing was conducted to evaluate the potential of each mat section and sand-geofiber section as an expedient road when placed over sandy subgrades. An analysis of the field data was conducted to determine the potential of these expedient pavements under actual loading conditions. A summary of each material investigated and its performance is presented in this report.

The results and observations of the field experiment revealed the following:

a. The control experiment indicated immobilization of the test vehicle after 25 passes when the loose sand was trafficked without any reinforcement or surfacing.

$b$. Sand-geofiber stabilization is adequate for straight and curved roadway sections. The $50-\mathrm{ft}$ and $75-\mathrm{ft}$ radius curved sand-geofiber sections were adequate to sustain 500 military truck passes over a 16-in. layer of loose sand.

c. The selected fiber content of 0.8 percent per dry weight of sand provided adequate support under the applied traffic.

d. The 8-in. stabilized sand layer provided adequate support for 500 passes of the 5-ton military truck.

e. Overall, the Allround hexagonal plastic mats provided poor load support for the 5-ton truck traffic and extremely poor load support in the $50-\mathrm{ft}$ radius curved section.

1 A table for converting non-SI units of measurement to SI units is presented on page vii. 
f. The Special hexagonal plastic mats provided adequate support for 500 passes of a 5-ton military truck in a straight section of the roadway, but the mats disconnected at the centerline of the lane and at the upheaval areas creating unstable structural support in the wheel paths after 500 passes.

g. The MP mats are adequate for straight and curved roadway sections. A 50 - $\mathrm{ft}$ radius section provided adequate structural support to sustain 500 passes of the 5-ton military truck.

$h$. The aluminum connector pins withstood flexures of the mat in excess of 3 in. The alignment tools were useful to align the mat holes and to install the connector pins. The anchors helped to stabilize the mats during turning maneuvers.

$i$. The MP mats, hexagonal plastic mats, and sand-geofiber stabilized technologies were confirmed as adequate alternatives to traditional road construction technologies for sand subgrades. These technologies were exposed to heavy rains, humidity, winds, and high and low temperatures for a period of 6 months. They were durable and low maintenance.

$j$. For the MP mat item, the installation rate was $253 \mathrm{ft}^{2}$ per man-hour. The installation time for the Allround hexagonal plastic mat was $585 \mathrm{ft}^{2}$ per man-hour. The installation rate for the Special hexagonal plastic mat was $786 \mathrm{ft}^{2}$ per man-hour. The installation rate for the sand-geofiber item was $209 \mathrm{ft}^{2}$ per man-hour.

Detailed information concerning the MP mat, hexagonal plastic mat, and geofiber sections is presented in this report. Chapter 1 consists of an introduction including background related to the research. Detailed material information is provided in Chapter 2 of this report. Chapter 3 presents the field experiments and their results. Chapter 4 presents an analysis based on performance under traffic. Finally, conclusions and recommendations are presented in Chapter 5. 


\section{Conversion Factors, Non-SI to SI Units of Measurement}

Non-SI units of measurement used in this report can be converted to SI units as follows:

\begin{tabular}{||l|l|l||}
\hline Multiply & By & To Obtain \\
\hline \hline angle (degree) & 0.01745329 & radians \\
\hline cubic feet & 0.02832 & cubic meters \\
\hline feet & 0.3048 & meters \\
\hline gallons & 3.785 & liters \\
\hline gallons per square yard & 4.5273149 & liters per square meter \\
\hline inches & 2.54 & centimeters \\
\hline kilosecond-feet & 28.32 & cubic meters per second \\
\hline kips, (1,000 lb) & 0.4535924 & 1,000 kilograms \\
\hline miles & 1.609347 & kilometer \\
\hline ounces & 0.02957353 & liters \\
\hline pounds (force) per square inch & $6.894757 \times 10^{-3}$ & megaPascals \\
\hline pounds (force) per square foot & 47.88026 & Pascals \\
\hline pounds (mass) & 0.4535924 & kilograms \\
\hline pounds (mass) per cubic foot & 0.157 & kilonewtons per cubic meter \\
\hline square feet & 0.09290 & square meters \\
\hline square inches & $6.4516 \times 10^{-4}$ & square meters \\
\hline square meters & 2.59 & square kilometers \\
\hline square yards & 0.8361 & square meters \\
\hline tons & 907.1 & kilograms \\
\hline \hline
\end{tabular}




\section{Preface}

The investigation described in this report was sponsored by Headquarters, U.S. Army Corps of Engineers, under the project: DT08, "Enhanced Coastal Trafficability/Sea State Mitigation ATD." The Army technical monitor was Dr. Paul Mlakar.

This publication was prepared by the U.S. Army Engineer Research and Development Center (ERDC), Geotechnical and Structures Laboratory (GSL), Vicksburg, MS, based upon experiments conducted during the period June through December 2001. Staff members actively engaged in the planning and implementation of the investigation were Ms. Rosa L. Santoni, Messrs. Carroll J. Smith, Jeb S. Tingle, Steve L. Webster, Travis Mann, Patrick McCaffrey, Timothy McCaffrey, and Louis W. Mason, Airfields and Pavements Branch (APB), GSL. Technical assistance was also provided by Messrs. Dennis J. Beausoliel, Timothy Conrad, and Charles Wilson, Directorate of Public Works. This publication was prepared by Ms. Santoni under the general supervision of Dr. David W. Pittman, Acting Director, GSL, and under the direct supervision of Dr. Albert J. Bush III, Chief, Engineering Systems and Materials Division, and Mr. Don R. Alexander, Chief, APB.

Commander and Executive Director of ERDC was COL James R. Rowan, EN. Dr. James R. Houston was Director. 


\section{Introduction}

\section{Background}

A Logistics-Over-The-Shore (LOTS) operation is the process of discharging cargo from vessels anchored off-shore or in-the-stream, transporting it to the shore and/or pier, and marshalling it for movement inland (Joint Tactics, Techniques, and Procedures for Joint Logistics Over-the-Shore, Joint Pub 4-01.6). LOTS operations are conducted over unimproved shorelines, through fixed ports not accessible to deep-draft shipping, and through fixed ports that are inadequate without using LOTS capabilities. Joint-Logistics-Over-theShore (JLOTS) operations are defined as operations in which Navy and Army forces conduct LOTS operations together under a joint force commander. These exercises test and evaluate the capabilities of the services to deliver logistics support from ships to forces ashore in areas where there are no usable port facilities or transportation infrastructure. Frequently, the unimproved shorelines and inland soils do not possess adequate strength to support trafficability of heavy military vehicle and equipment.

Poor soil conditions can delay military operations due to reduced mobility or immobilization of vehicles and/or equipment. Excessive fuel and maintenance costs can also be expected when poor soil conditions are encountered. The U.S. Army Engineer Research and Development Center (ERDC) has been developing expedient road systems to overcome poor soil conditions encountered along shorelines since the 1960s. ERDC developed aluminum and steel mats for military airfields. These mats were classified as a light-duty steel mat, a medium-duty aluminum mat, and a heavy-duty truss web aluminum mat. They were developed to withstand various types of aircraft operations on a 4-CBR subgrade. Mo-Mat, M8A1 steel mat, and Uni-Mat were also used to construct expedient roads in sandy soil conditions. These systems are no longer available on the commercial market; only limited supplies of these mats exist in inventory. These mats designs have significant limitations such as poor transportability, extremely bulky and heavy, and require significant maintenance when used in curved roadway sections.

In October 1995, ERDC advertised request for proposals (RFP) in the Commerce Business Daily for lightweight surfacing to satisfy aircraft and truck load requirements. Six companies responded to the RFP and after evaluations, the ERDC purchased test mat quantities from four of the companies. Limited field evaluations of the four mats revealed that all mats were not capable of sustained aircraft traffic. However, the fiberglass mats demonstrated significant 
potential for supporting military truck traffic in evaluations conducted during 1997. This original mat evaluation also showed poor installation characteristics. Consequently, ERDC researchers developed a new mat configuration and pin connector using the same material as reported in TR GL-98-10. The hexagonal plastic mats also demonstrated significant potential for supporting military truck traffic.

Therefore, ERDC was tasked to develop new expedient road systems to overcome poor sandy soil conditions with a reduced logistics footprint (i.e., less volume and weight). Sand-geofiber stabilization, multi-purpose mat (fiberglass mat), and hexagonal plastic mat are three new expedient road systems evaluated by ERDC. These systems are light, easy to install, and have low logistics requirements.

\section{Objective}

The objective of this investigation was to evaluate sand-geofiber stabilization, multi-purpose (MP) mat, and hexagonal plastic mat as expedient road system over loose sand.

\section{Scope}

The objective of this investigation was accomplished by the construction and testing of a specially designed test section as described herein. The test road that contained three test items composed of each system was subjected to accelerated traffic of a 5-ton military truck. This report describes the materials used in the test section, construction techniques, and behavior of each material under traffic. A summary of findings and recommendations is also presented. 


\section{Materials}

The materials used in the experiment were divided into three categories: unreinforced sand, geofiber-reinforced sand, and mat systems. Properties of each material are provided in the text and complemented with tables.

\section{Unreinforced Sand}

The sand used for the experiment was a sand local to Vicksburg, MS, normally used as fine aggregate in concrete. The sand was a pit-run washed sand containing approximately 4 percent gravel sizes and 2 percent minus No. 200 U.S. standard sieve size material. It was classified as a poorly graded (SP) sand, American Society for Testing and Materials (ASTM) D 2487 (ASTM 1992). Additional material properties for the sand are provided in Table 1 (dry unit weights were determined according to ASTM D 4253 (ASTM 1993)).

\begin{tabular}{|c|c|}
\hline $\begin{array}{l}\text { Table } 1 \\
\text { Sand Properties }\end{array}$ & \\
\hline Property & Value \\
\hline Specific gravity & 2.65 \\
\hline Laboratory maximum, dry unit weight, $\mathrm{lb} / \mathrm{ft}^{3}$ & 117.70 \\
\hline Laboratory minimum, dry unit weight, $\mathrm{lb} / \mathrm{ft}^{3}$ & 98.20 \\
\hline Coefficient of uniformity, $\mathrm{C}_{u}$ & 2.00 \\
\hline Coefficient of curvature, $\mathrm{C}_{\mathrm{c}}$ & 1.23 \\
\hline Plasticity index & Nonplastic \\
\hline Percent finer that no. 200 sieve & 2.00 \\
\hline Grain size & Medium \\
\hline Mean diameter, $\mathrm{D}_{50}$ (in.) & 0.02 \\
\hline Fineness modulus & 2.31 \\
\hline
\end{tabular}

\section{Geofiber-Reinforced Sand System}

Geofiber. The sand described previously was reinforced with hair-like 2-in.-long monofilament geofibers at a rate of 0.8 percent by dry weight of sand. The geofibers were mixed into moist sand using a self-propelled rotary mixer. These 2-in. polypropylene geofibers have a specific gravity of $0.91 \mathrm{lb} / \mathrm{ft}$, a tensile strength of 75,000 psi, and a Young's modulus of 500,000 psi. The 20 -denier monofilament geofibers were used in this investigation. A denier is the mass in 
grams of a 27,528-ft length of a geofiber, and it is used as a measure of fineness as developed by the textile industry. The sand-geofiber mix can withstand an unconfined compressive strength of 21 to $27 \mathrm{psi}$ for a 0.5 - and 1 -in. deformation, respectively. The cost of the fiber is $\$ 1.60$ per pound (Tingle et al. 1999 and Webster and Santoni 1997).

Road Oyl. Road Oyl was used to stabilize the wearing surface. Road Oyl is a resin-modified emulsion that is nonwater soluble and has a high bonding strength. It was developed specifically for use in pavement applications, dust control treatment, soil stabilization, and erosion control. It contains selected fractions of natural tree resins combined with a strong bonding agent. It can be field mixed with premoistened materials or diluted with water and sprayed on for surface penetration. It is petroleum-free and can be cold-applied. The boiling, freezing, and flash points of the Road Oyl are $212^{\circ} \mathrm{F}, 33^{\circ} \mathrm{F}$, and $400^{\circ} \mathrm{F}$, respectively. Road Oyl is environmentally friendly and available for bulk shipments, 55-gal drums, and 275-gal pelletized bulk container packaging. The Road Oyl used in the field experiments was purchased in 55-gal drums for $\$ 4.20$ per gallon. The bulk price was approximately $\$ 1.79$ per gallon plus $\$ 2.00$ per mile per 6,000-gal truck load.

\section{Mat Systems}

Two mats were selected for this study based on a literature review and recent studies conducted at ERDC (Santoni et al. 2001 and Tingle and Webster 1998). These mat systems are described below.

\section{Multi-Purpose (MP) mat}

Description. The MP mat dimensions are $6 \mathrm{ft}, 8$ in. by $6 \mathrm{ft}, 8$ in. by approximately 0.35 in. thick (Figure 1). Each MP mat panel has a flat surface area with downward fold sides on two panel edges. The downward fold sides provide a bottom ledge for connecting with adjacent mat panels. Each panel edge contains three rectangular holes for connecting adjacent panels. The holes on the upper panel edges are slightly larger than the connector holes on the downward fold edges. Figure 2 illustrates the top and bottom rectangular hole dimensions. The mat surface has a skid resistant texture defined by the woven roving weave pattern of the top ply of fiberglass material, which is not smoothed over by the use of excess resin. The usable surface area when installed is approximately $36 \mathrm{ft}^{2}$. The weight of a panel is approximately $115 \mathrm{lb}$ with a unit weight of $2.59 \mathrm{lb} / \mathrm{ft}^{2}$. The cost for each MP mat panel is $\$ 320$. The MP mat was fabricated by GFI, Inc., Harrison, AR (www.GFIinc.us). The geometric configuration of the mat was designed by ERDC to optimize structural performance, installation rate, and deployability. The MP mat has a pending patent.

Materials. The mat is constructed of fiberglass-reinforced polyester composite. It consists of a polyester resin reinforced with four plies of woven chopped fiberglass (GFI 1996). The resin is known as CoRezyn 105-58, and it is both corrosion and chemical resistant. This resin meets the requirements of the Navy Military Specification MIL-R-21607. The resin is a low-pressure 
thermosetting polyester, laminating type, which contains a styrene suppressant that will not adversely affect secondary bonding or environmental stability of the mat. Ultra-violet (UV) inhibitors are added for product protection. The polyester resin-to-fiberglass ratio is approximately $11: 9$ by weight.

The fiberglass reinforcement is a fiberglass fabric mat reinforcement composite type E (Navy Military Specification MIL-M-43248). This composite is made of a plain-weave pattern of roving bonded to a chopped fiberglass mat. One ply is defined as the combination of the woven roving bonded to the chopped fiber layer. The woven roving is constructed by weaving, in a plain wave, 113 linear yards per pound fiberglass roving into a pattern consisting of four roving per inch in the warp by two roving per inch in the fill directions, respectively. The woven roving consists of continuous filament yarns and has an average weight of $40.8 \pm 2.4$ ounces per square yard. The chopped fiber layer consists of randomly oriented fibers of 1.5 to $2.5 \mathrm{in}$. long. The fibers are designed as type $\mathrm{K}$ fibers with an average diameter of 0.00051 in., or type $\mathrm{H}$ fibers having an average diameter of 0.0004 in. The chopped fiber weighs $2.0 \pm$ 0.2 ounces per square foot (GFI 1996).

Aluminum drop-in pin connectors. The MP mat panels are connected together by using aluminum pin connectors (Figure 3 ). These connectors were designed at ERDC. The pin connector is comprised of top and bottom aluminum plates along with a hexagonal button head cap screw with an internal tooth washer (Figures 4 and 5). The cap screw is recessed into the top pin connector plate and the edges of the top plate are rounded to present a low pin connector profile on the surface of the connected mat panels (Figures 3 and 5). A service removable medium strength thread locker (Loctite ${ }^{\circledR}$ type 242) was applied to the cap screw threads before assembly with the bottom plate. The thread locker provides sufficient strength for the bottom plate to rotate 90 degrees below the bottom mat panel (Figures 3 and 5).

A cam on the bottom pin plate stops rotation of the bottom plate at 90 degrees to the holes in the mat panels. The rotated bottom plate below the bottom mat panel then allows the pin connector to be tightened and lock the two mat panels together. During tightening, the thread locker breaks under medium torque to allow the cap screw to be fully tightened. During disassembly, the thread locker again breaks under moderate torque allowing the cap screw to be loosened. As the pin is loosened, the thread locker retains sufficient locking strength to force the bottom plate to rotate back 90 degrees. After rotating 90 degrees, the cam on the bottom pin plate stops the rotation to align the bottom plate with holes in the mat panels. The aluminum drop-in pin connectors are then removed.

The drop-in pin connectors were fabricated with aluminum type 6061-T6. Table 2 shows the aluminum mechanical properties and its chemical analysis. The pin connectors were fabricated using 868-lb extruded QQ A 200/8 aluminum bars. These bars have a rectangular cross section and are $12 \mathrm{ft}$ long. 
Anchoring system. The MP mat item was anchored using a multi purpose Duckbill anchor system to prevent excessive movement caused by shear and centrifugal forces acting on curved sections. The anchor was driven into the ground using a hammer and a steel drive rod. The Duckbill anchor worked as a toggle bolt when rotate in undisturbed soil (Figure 6). For this investigation, the selected model was the 68-DB1. The anchor's manufacturer provided the engineering properties (www.earthanchor.com). The anchor holding power in normal soil is $1,100 \mathrm{lb}$. The wire rope breaking strength is $1,700 \mathrm{lb}$, and its length is $2.5 \mathrm{ft}$. The anchor weight is 4.5 ounces. The steel drive rod diameter is 0.5 in. The anchor's material properties are as follows: casting method - die cast, aluminum alloy $-\mathrm{k}-9$, tensile yield strength $-20,700 \mathrm{psi}$, ultimate tensile strength $-26,500 \mathrm{psi}$, and elongation -3.5 percent. Anchors were shipped in boxes of twenty-four with a total weight of $2 \mathrm{lb}$ per box. Basic dimensions of the anchor and steel drive rod are shown in Figures 7 and 8, respectively. A total of 960 anchors and 2 steel drive rods were purchased for this experiment. The cost of the anchor and driven steel rod was $\$ 4.40$ and $\$ 28.50$, respectively.

\begin{tabular}{|c|c|}
\hline \multicolumn{2}{|c|}{$\begin{array}{l}\text { Table } 2 \\
\text { Properties of the Aluminum Connector Pin and Anchors }\end{array}$} \\
\hline Mechanical Property & Value \\
\hline \multicolumn{2}{|c|}{ Aluminum Connector Pin } \\
\hline Yield Stress, ksi & 40.4 \\
\hline Ultimate Tensile Stress, ksi & 43.4 \\
\hline Percent of Elongation & 98.2 \\
\hline \multicolumn{2}{|c|}{ Anchor } \\
\hline Casting Method & Die cast \\
\hline Aluminum alloy & k-9 \\
\hline Tensile Yield Strength, psi & 20700 \\
\hline Ultimate Tensile Strength, psi & 26500 \\
\hline Elongation, percent & 3.5 \\
\hline \multicolumn{2}{|c|}{ Steel Drive Rod } \\
\hline Production Method & Cold formed \\
\hline Tensile Yield Strength, psi & 85000 \\
\hline Ultimate Tensile Strength, psi & 74000 \\
\hline Elongation, percent & 18 \\
\hline
\end{tabular}

Laboratory tests. The MP mat samples and pin connectors were tested to determine their performance under both compression and tension loads. Samples of an MP mat were taken from a panel that was part of the 350 panels purchased for the field test. Figure 9 shows the samples' location on the MP mat panel. Different sample sizes as well as downward fold samples were tested. The aluminum drop-in pin connectors used during these laboratory tests were fabricated at ERDC. The 3-point beam test was used to evaluate the load carrying capacity of the mat and pin connector under compressive loads. A direct tension test was used to determine the mat and pin connector performance under tensile load. The flexural strength was evaluated to determine if a difference in the 9-in. and 6-in. spans would make a difference in the flexural strength (ASTM D 6272). The tensile strength test was used to determine the ultimate tensile strength according to ASTM D 3039. Figure 10 and Photos 1 through 6 show the test set up. Tables 3 and 4 show the test results. The beam 
and tension tests were conducted using an Instron $(4208$ testing system. The Instron ${ }^{\circledR}$ system consists of the test loading instrument and a computer for loadtime recording of results. The load was applied to each MP mat samples at a constant crosshead rate of 0.25 in. per minute. Results were recorded every 0.02 in.

The results showed that the MP mat was stronger in the traffic direction (Figure 9 and 19) or suggested placement. The MP mat connection area was the weakest area of the mat. The MP mat downward fold sides were weaker than the center section of the mat. The aluminum pin connector performed excellent during the tests. Finally, the results were directly proportional to the sample size and span. The larger MP mat samples and span provided higher load.

\section{Hexagonal plastic mat}

Description. This mat was produced by UmTech - Ecological Technology Company, Inc., Munich, Germany. Test panels were purchased from the U.S. distributor, Grid Tech of Newport, Rhode Island. These lightweight interlocking mat panels were designed for quick installation to create parking areas and access roadways. The panels are ultraviolet (UV) stable and made from recycled HDPE.

Each panel weighs $7.05 \mathrm{lb}$ and has a surface area of approximately $2.9 \mathrm{sq} \mathrm{ft}$, resulting in a unit weight of $2.43 \mathrm{psf}$. The factory recommended maximum wheel load is $13,000 \mathrm{lb}$ per panel when installed over a gravel base. The hexagonal form permits road angles of 30,60 , and 90 degrees to be created. The cost of test quantities of the mat was $\$ 7.25$ per sq $\mathrm{ft}$.

Two types of the hexagonal plastic mats were used in this field experiment: Allround and Special. The Allround hexagonal plastic mat is shown in Photos 7 and 8. The Special hexagonal plastic mat is shown in Photos 9 and 10. Both mats can support 13,000 lb per panel. Both mats have skid resistance texture to improve tire traction. The Allround mat has handles that ease its installation (Photo 11). The Allround and Special mats have 12 and 18 reinforcement ribs, respectively (Photo 12). 


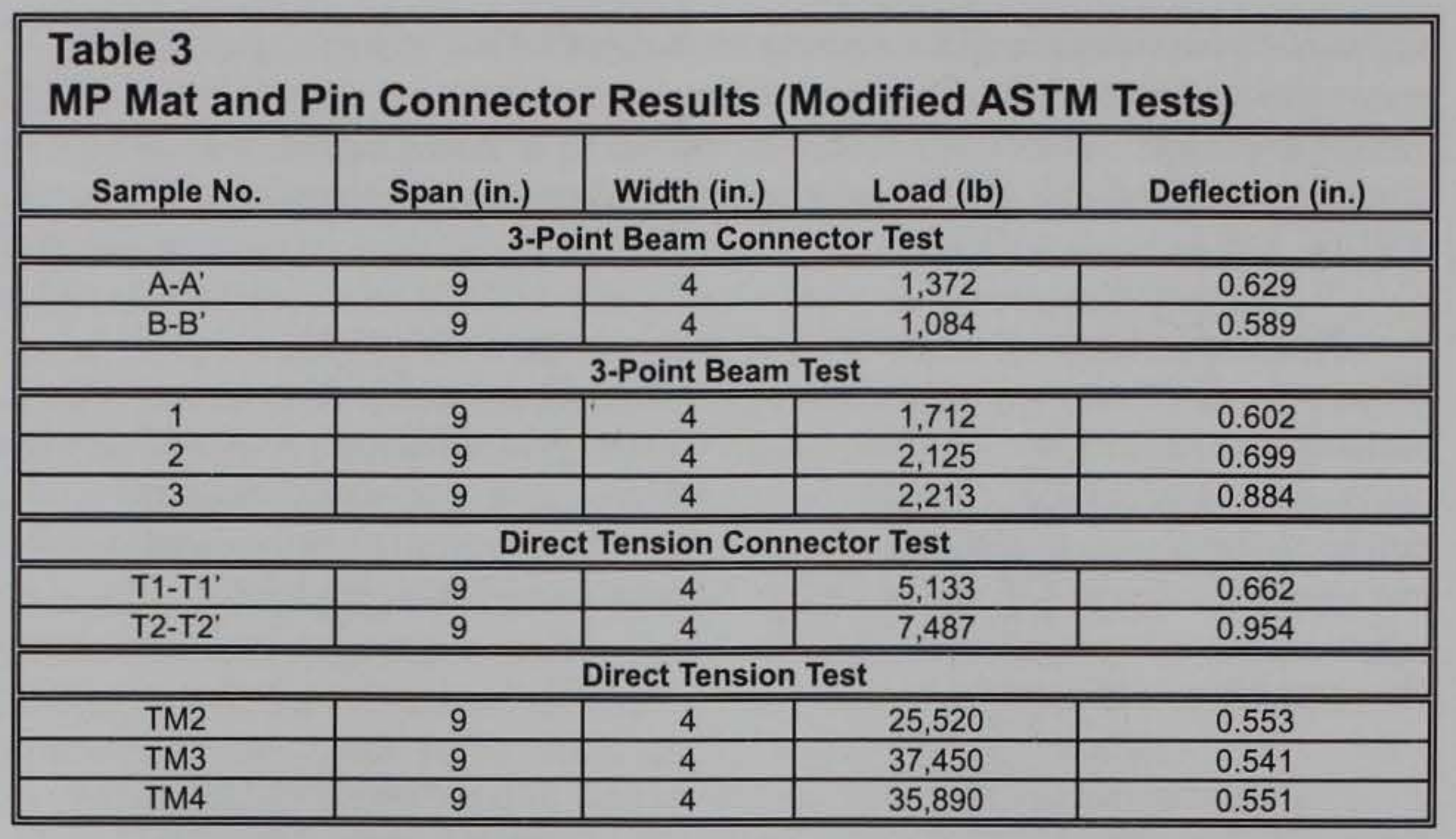

\begin{tabular}{|c|c|c|c|c|c|c|}
\hline \multicolumn{7}{|c|}{$\begin{array}{l}\text { Table } 4 \\
\text { MP Mat and Pin Connector Results (ASTM Tests) }\end{array}$} \\
\hline Sample No. ${ }^{1}$ & $\begin{array}{l}\text { Span } \\
\text { (in.) }\end{array}$ & $\begin{array}{l}\text { Width } \\
\text { (in.) }\end{array}$ & $\begin{array}{l}\text { Depth } \\
\text { (in.) }\end{array}$ & $\begin{array}{l}\text { Load } \\
\text { (lb) }\end{array}$ & $\begin{array}{l}\text { Deflection } \\
\text { (in.) }\end{array}$ & $\begin{array}{l}\text { Strength } \\
\text { (psi) }\end{array}$ \\
\hline \multicolumn{7}{|c|}{ Beam Test (9 in. span) ${ }^{2}$} \\
\hline $\mathrm{A} 1$ & 9 & 2.00 & 0.375 & 1,182 & 0.739 & 37,824 \\
\hline $\mathrm{A} 2$ & 9 & 2.00 & 0.385 & 1,421 & 0.873 & 43,140 \\
\hline $\mathrm{A} 3$ & 9 & 1.90 & 0.383 & 1,514 & 0.888 & 48,890 \\
\hline B1 & 9 & 1.98 & 0.365 & 478 & 0.483 & 16,310 \\
\hline B2 & 9 & 1.98 & 0.360 & 1,020 & 1.070 & 35,710 \\
\hline B3 & 9 & 1.95 & 0.366 & 409 & 0.410 & 14,090 \\
\hline \multicolumn{7}{|c|}{ Beam Test (6 in. span) ${ }^{2}$} \\
\hline A5 & 6 & 1.375 & 0.360 & 970 & 0.273 & 32,660 \\
\hline A6 & 6 & 1.375 & 0.370 & 1,024 & 0.285 & 32,640 \\
\hline A7 & 6 & 1.374 & 0.360 & 1,073 & 0.309 & 36,150 \\
\hline $\mathrm{B} 5$ & 6 & 1.375 & 0.345 & 475 & 0.217 & 17,410 \\
\hline $\mathrm{B} 6$ & 6 & 1.375 & 0.345 & 960 & 0.418 & 33,620 \\
\hline B7 & 6 & 1.375 & 0.353 & 743 & 0.364 & 26,470 \\
\hline B8 & 6 & 1.375 & 0.350 & 982 & 0.479 & 35,020 \\
\hline \multicolumn{7}{|c|}{$\begin{array}{c}\text { Tensile Strength Test } \\
{ }^{3} \\
\end{array}$} \\
\hline T1 & - & 1.10 & 0.343 & 9,555 & 0.331 & 25,330 \\
\hline T2 & -- & 1.01 & 0.345 & 9,635 & 0.327 & 27,650 \\
\hline T3 & -- & 1.00 & 0.350 & 9,735 & 0.338 & 27,810 \\
\hline S1 & - & 1.00 & 0.370 & 6,388 & 0.389 & 17,270 \\
\hline S2 & -- & 0.99 & 0.375 & 7,973 & 0.319 & 21,480 \\
\hline S3 & -- & 0.99 & 0.365 & 6,568 & 0.355 & 18,180 \\
\hline \multicolumn{7}{|c|}{$\begin{array}{l}\text { A1 and A3 (downward fold) and A2, and A4 (center) }-2 \text { in. } \times 12 \text { in. samples. } \\
\text { A5 and A7 (downward fold) and A7 (center) }-13 / 8 \text { in. } \times 12 \text { in. samples. } \\
\text { B1 and B3 (downward fold) and B2 and B4 (center) }-2 \text { in. } \times 12 \text { in. samples. } \\
\text { B5 and B7 (downward fold) and B6 and B8 (center) }-13 / 8 \text { in. } \times 12 \text { in. samples. } \\
\text { T1 and T3 (downward fold) and T2 (center) }-1 \text { in. } \times 12 \text { in. samples. } \\
\text { S1 and S3 (downward fold) and S2 (center) }-1 \text { in. } \times 12 \text { in. samples. } \\
\text { ASTM D6272. } \\
\text { ASTM D3039. }\end{array}$} \\
\hline
\end{tabular}




\section{Field Experiments}

\section{Experiment Design}

\section{Description}

The field experiment for this investigation was conducted in an outdoor environment on the ERDC reservation. The site of the experiment was located on the northeast end of Brown's Lake within a dredge fill containment area, which is encircled by a gravel-surfaced road (Susquehana Circle). Plan and profile drawings of the loose sand experiment site are shown in Figures 11 and 12, respectively. Item 1 was constructed using the MP mats, Item 2 was constructed using the hexagonal plastic mats (Allround and Special), and Item 3 was constructed using sand-geofiber stabilization. The experiments were designed to evaluate the load-carrying capabilities of the various expedient roadway systems under military truck traffic when installed as roadway sections over the sandy soils. Construction procedures and design parameters were also validated. The road sections were designed for single-lane traffic.

\section{Materials}

The subgrade for this experiment was the poorly-graded loose sand (SP) described in Chapter 2. The loose sand was the subgrade underlain by the dredged material that was composed of soils dredged from Brown's Lake and dumped in the fill containment area. These dredged soils have been contained in this area since the 1980's. Local soils in the Vicksburg, MS, area are loess deposits, and subgrade sediments in the containment are classified as a lowplasticity silt (ML). Classification data for the subgrade material are shown in Figure 13. The mats, unreinforced sand, and geofibers used in the experiment are those described in Chapter 2. All materials except the connecting pins for the Multi-Purpose mats were commercially available products. The connector pins were under development at the time of the experiment and were fabricated according to ERDC specifications. 


\section{Construction}

\section{General}

The test section was constructed and evaluated during the period June through December 2001. All construction work was accomplished by ERDC personnel using conventional construction equipment. Items 1 through 3 were arranged in an oval configuration so continuous truck traffic could be applied over the items. The existing dredge material (ML soil) had an average CBR of 9 percent. The existing material was not disturbed, but two sections at the edge of the gravel-surfaced road were cut to fit the oval section with the boundary conditions (Photos 13 and 14). At the outside and inside edge of shoulders, flags and strings lines were placed. The flags were placed every $5 \mathrm{ft}$. Over the existing dredge material, 12 - to 28 -in. sand layer was delivered by dump truck and leveled with a D4 bulldozer (Photos 15 through 17). The difference in the sand layer thickness was to overcome the irregular topographic ground contour (Figure 14). To replicate the loose conditions of beach sand, the $36-\mathrm{ft}-$ wide sandy base course layer was not compacted. Two pipes were placed in the sandy base's toe so that the water level could flow naturally within all experiment areas (Photos 18 and 19). An aerial view of the experiment site prior to items installation is shown in Photo 20. Figure 14 shows the elevations and field test section location. The roadway's loose sand condition was demonstrated by a 5-ton military truck loaded to $41,600 \mathrm{lb}$ becoming immobilized after 25 passes. Photos 21 and 22 show the 10 -in. rut depth after 25 passes of the 5-ton military truck.

\section{Description}

Multi-Purpose mat (Item 1). Item 1 was constructed using the MP mats. It was divided into two sections consisting of a straight section and a 50 - $\mathrm{ft}$ radius curved section (Figures 11 and 12). A total of $146 \mathrm{MP}$ mats and 510 connector pins were used for this item. The connector pins used for Item 1 were assembled prior to construction as shown in Photos 23 and 24. Figure 16 shows the pin assembly procedure. A 0.25 -in. gap between the pin top and bottom plates was set using the spacer guide tool (Figure 17). An MP mat access ramp was installed as a patch and then connected to the main Item 1 sections (Photo 25). The MP mat ramp was $24-\mathrm{ft}$ wide by 42 - $\mathrm{ft}$ long. A ramp was constructed to provide access to the three items (Photo 27). Item 1's straight section was approximately $54 \mathrm{ft}$ long and $24 \mathrm{ft}$ wide (Photo 26). Item 1 's $50-\mathrm{ft}$ radius curve section had an inside radius of $50 \mathrm{ft}$ and an outside radius of $74 \mathrm{ft}$ (Photo 27). The section width was $24 \mathrm{ft}$. A plan and profile of the sections are shown in Figures 11 and 12, respectively.

Hexagonal plastic mat (Item 2). Item 2 was constructed using two types of hexagonal plastic mats. The hexagonal plastic mat properties were described in Chapter 2. Item 2 was divided into two sections consisting of the Allround and Special hexagonal plastic mat sections (Figure 15). The Allround section had an inside radius of $50 \mathrm{ft}$ and an outside radius of $74 \mathrm{ft}$ (Photo 28). This section was approximately $24 \mathrm{ft}$ wide. A plan and profile are shown in Figures 11 and 12. 
The Special section was a straight section, and it was approximately $50 \mathrm{ft}$ long by $24 \mathrm{ft}$ wide (Photo 29).

Sand-geofiber stabilization (Item 3). Item 3 was constructed using the geofiber stabilization technique. The geofiber and sand properties were described in Chapter 2. Item 3 was divided into three sections: a 75 - $\mathrm{ft}$ radius curved section, a $50-\mathrm{ft}$ radius curved section, and a straight section (Figure 15). The two curved sections were approximately $24 \mathrm{ft}$ wide (Photos 30 and 31 ). The straight section was approximately $25 \mathrm{ft}$ long by $24 \mathrm{ft}$ wide (Photo 32). Plan and profile drawings of Item 3 are shown in Figures 11 and 12, respectively.

\section{Construction}

Transition zones. Three transition zones were located between MP mat $50-\mathrm{ft}$ radius curve section and Allround hexagonal plastic mat (Photo 33), Special hexagonal plastic mat and 75- $\mathrm{ft}$ radius curve sand-geofiber section (Photo 34), and 50 - $\mathrm{ft}$ radius curve sand-geofiber section and MP mat straight section (Photo 35). The first transition zone, MP mat 50-ft radius curve section and Allround hexagonal plastic mat, consisted of placing two rows of hexagonal plastic mats underneath the MP mat section. This transition zone was approximately $3 \mathrm{ft}$ long by $24 \mathrm{ft}$ wide. The second transition zone, Special hexagonal plastic mat and 75 - $\mathrm{ft}$ radius curve sand-geofiber section, consisted of placing the sand-geofibers then three rows of Special hexagonal mats were place on top of the stabilized zone. This second transition zone was approximately $5 \mathrm{ft}$ long by $24 \mathrm{ft}$ wide. The third transition zone, 50 - $\mathrm{ft}$ radius curve sand-geofiber section and MP mat straight section, consisted of placing sand-geofiber then two rows of the MP mats were installed over the stabilized zone. This transition zone was approximately $12 \mathrm{ft}$ long by $24 \mathrm{ft}$ wide.

Multi-Purpose mat (Item 1) installation. String lines and flags were used as a construction guide to outline the boundaries of the section. Construction began by delivering the banded MP mat pallets to the installation site using a forklift (Photos 36 and 37). Each pallet had 15 MP mats. The MP mats for the 50 - $\mathrm{ft}$ radius curve section were placed over six rows of previously installed Allround hexagonal plastic mats (Photo 33). The first row of MP mat was placed with the downwarp fold sides facing north and west. The MP mat roadway consisted of four panels wide and centered on the item. The downwarp mat edges were meshed together, holes in the panel edges were aligned, and connector pins were inserted through the holes and tightened to secure the individual panels. Photos 38 to 40 show the alignment tool designed to ease installation of the MP mats and connector pins. The alignment tools were designed and produced at ERDC. Figure 18 shows the basic dimensions of the alignment tools used in this investigation. The alignment tools were used to guide the mats into position and to align mat holes during connector pin placement (Photos 41 to 43). Once the MP mat holes were aligned, the connector pins were installed and pre-tightened by turning the hex-bolt 360 degrees (one turn). The pins were pre-tightened to rotate the pin bottom plate 90 degrees and lock the pin in-place. Since the connector pins of in-place MP mats were loose, the mats to be installed and holes were easily aligned with the alignment tools. The pin pre-tightening was done with a hand tool as shown in Photo 44. The final pin tightening was done with an impact drill with a hexagonal bit 
(Photo 45). The installation procedure for the MP mat is illustrated in Figure 19. The MP mat item was anchored to prevent any movement due to shear forces in the curved sections. MP mats were anchored using Duckbill anchors (Photo 46). A total of 16 anchors were placed in the inside edge of the MP mat section (Figures 11 and 12). The anchor cable was inserted throughout the MP mat holes (Photo 47). Then the anchor was passed throughout the cable's eye to loop the anchor and fasten the mat to the ground (Photo 48). Finally, the anchor was driven into the soil using a hammer and steel drive rod as shown Photos 49 and 50. Some anchor cables had small cable's eyes; therefore, the anchors were not able to pass throughout the loop. These irregular anchors were discarded.

Hexagonal plastic mat (Item 2) installation. The edges of Item 2 edges were lined up with flags and string lines. Construction began by delivering the banded Allround hexagonal plastic mat pallets to the installation site using a small forklift (Photos 51 and 52). This method provided a continuous supply of panels to the laborers during placement. Each pallet had 80 hexagonal plastic mats. The installation procedure is illustrated in Figure 20. The installation procedure consisted of three main steps. In Step 1, the Allround mats were laid down starting at the right corner of the section as shown Figure 20 and Photo 53. The mat was then released in Step 2 (Photo 54). Finally, the mat was set in-place by stepping on it (Photo 55). Once the first row of mats (mat 1 through 16) was placed, rows 17-32, 33-48, and following, were then connected by hanging the hook into the handle and by connecting the mat to the two remaining free hooks. The Allround hexagonal plastic mat roadway consisted of 16 mats wide and centered on the item to create a 50 -ft-radius curve road. Photos 56 and 57 show the installation progress of the Allround hexagonal plastic mat section. Photo 58 shows the final section.

The Special hexagonal plastic mat installation was similar to the Allround mat installation (Photos 59 and 60). The Special hexagonal mats were delivered on banded pallets using a forklift. Each pallet had 80 hexagonal plastic mats. The installation procedure is illustrated in Figure 21. The first Special hexagonal mat was laid down starting at the left corner of the Special section Figure 21. Once the first row of Special mats (mats 1 through 14) was placed, rows 15-28, 29-32, and following, were then connected by hanging the hook into the mat. The installation of both mats required no specialized tools or skills. The Special hexagonal plastic mats were directly connected to the Allround hexagonal plastic mats (Figure 22 and Photos 61 and 62).

After installation, the Allround and Special hexagonal plastic mat sections were compacted using a steel-wheel vibratory compactor (Photo 63) to embed the mat in the sand. The compaction equipment pushed the mats into the sand. The mat radial ribs (Photos 8, 10, and 12) increased the friction between the mat and sand and served as an anchor system. When the steel-wheel roller was moving from the MP mat item to the sand-geofiber item, it compacted the mats with vibration (forward). The compactor did not provide any vibration when it moved backward. Item 2 was compacted using six overlapping passes of a steel-wheel vibratory roller. 
Sand-geofiber stabilization (Item 3) installation. Item 3 consisted of the in-place stabilization of the sand using synthetic geofibers. All work was accomplished using conventional U.S. Army construction equipment. The item was divided into three sections (i.e., a 75 - $\mathrm{ft}$ radius curve section, a $50-\mathrm{ft}$ radius curve section, and a straight section) as shown in Figure 15. The test sections were constructed in a 28 -in.-thick by 36 -ft-wide concrete sand layer. Since the difference between the three sections were geometrical dimensions, they were constructed at the same time. The sections of Item 3 were stabilized in-place. Moisture content samples were taken from the sand layer to calculate its dry weight using a nuclear gage device. The average moisture content was 2.3 percent. The average dry density for the item was $108.5 \mathrm{pcf}$. The target moisture content for the concrete sand was approximately 8 percent. Therefore, the water required to obtain the target moisture content was added prior to placing the geofibers on the sand. The appropriate amount of geofibers was calculated based upon the dry density and dry weight of the sand.

A 2 -in.-long monofilament geofiber was selected for this experiment. The amount of geofiber was set to 0.8 percent per dry weight of sand. Using the dry density of sand of $108.5 \mathrm{pcf}$, an approximate item area of $4,539 \mathrm{ft}^{3}$, and a thickness of $8 \mathrm{in}$., the calculated amount of geofibers was 3,932 lb. The geofibers were shipped in boxes (Photo 64). Each box had 15 bags, and each bag weighed $20 \mathrm{lb}$. The number of bags used in this experiment was 206 representing $4,120 \mathrm{lb}$. Due to the variation in moisture and irregular item area, the additional $188 \mathrm{lb}$ was minimal considering that it represented 0.04 percent of geofiber.

The sections were outlined using string lines and flags. Within each test section, marks were placed to outline the curved section radius. Marks were painted every $5 \mathrm{ft}$ to place 20 -lb geofiber bags (Photo 65). Four parallel lines were marked (Figures 11 and 12), and bags were placed (Photos 65 and 66). The parallel lines were spaced every $6 \mathrm{ft}$ between each other and $3 \mathrm{ft}$ from the outside and inside edges (Figures 11 and 12). Once the bags were placed over the marks, the plastic bags were removed, and geofibers were dumped over the marks. The piled geofibers were spread across the surface of the sand manually (Photo 67). Photo 68 shows the geofiber over the sand prior mixing. A self-propelled rotary mixer was used to mix the geofibers into the sand. The rotary mixer made four coverages ( 4 passes $=1$ coverage) across the sand-geofiber sections. The outside and inside edges were mixed first, followed by the inner section of the lane. Photos 69 and 70 illustrate the mixing process.

After the mixing process, a D4 dozer was used to level/smooth the sandgeofiber (Photo 71). Due to high temperatures and evaporation of the sandgeofiber moisture, water was sprayed using a water truck hose (Photo 72). Water was added to the Item 3 for about $25 \mathrm{~min}$. After the watering process, the sandgeofiber layer was compacted with five coverages $(5$ passes $=1$ coverage $)$ with the smooth drum vibratory compactor to form an 8-in.-thick base layer (Photo 73). The outside and inside edges of the lane were compacted first, followed by the inner section of the lane. Several areas in the sand-geofiber item depressed after compaction was completed. These areas were patched after the Road Oyl application. 
Following the compaction of Item 3, a total of 825 gallons of Road Oyl was applied to the sand-geofiber item using an asphalt distributor truck. It was applied at a rate of 1 gallon per square yard. This spray-on surfacing material was shipped in 55 gal drums. Each drum was shaken by rolling the drum backward and forward on the ground for about $15 \mathrm{ft}$ (Photo 74). The operation of the asphalt distributor truck was tested at the test sections using water to verify the nozzles, spray bar range, speed, and pressure gauges prior to applying the Road Oyl. Then, 15 drums were pumped into the asphalt distributor tank at a rate of $150 \mathrm{gal} / \mathrm{min}$ (Photo 75 ). The tank capacity was $1,500 \mathrm{gal}$. The spray bar width was $12 \mathrm{ft}$, containing 12 nozzles, and it was $12 \mathrm{in}$. above the ground. The Road Oyl was pumped through spray bar nozzles at a rate of $150 \mathrm{gal} / \mathrm{min}$ (Photo 76). The spray-on surfacing was allowed to cure for $24 \mathrm{hr}$.

As mentioned previously, several locations in the sand-geofiber item were patched to repair densified areas. The patching was done after the Road Oyl application and before final compaction. The sand-geofiber mix for the patching was prepared in a staging area. The moisture content of the sand stockpile was 8 percent. The total amounts of sand and geofibers used for this patch mixing were $25,000 \mathrm{lb}$ and $200 \mathrm{lb}$, respectively. The sand was weighed out using the difference in weight of an empty and loaded front-end loader. The sand was placed in the staging area where it was leveled to a depth of approximately $1 \mathrm{ft}$ using a D4 bulldozer. The amount of geofibers was weighed and uniformly spread across the surface of the moist sand. A self-propelled rotary mixer was used to mix the geofibers into the sand. The rotary mixer made four initial passes across the sand-geofiber mix. Then, the mix was piled and releveled with a front-end loader. Following the releveling, four additional passes of the rotary mixer were made. The sand-geofiber was then piled and ready for installation at the site. The depressed areas were patched by using the Bob-Cat equipment and two pitch forks (Photo 77).

Finally, four passes of the vibratory steel-wheel roller were applied to seal the surface (Photo 78). The outside and inside edges of the lane were compacted first, then the center section of the lane. In the patched areas, the sand-geofiber pealed off with compaction due to the adhesion of the Road Oyl. Several lessons were learned during the patching of the sand-geofiber item. First, the depressed areas need scarification before placing the patching sand-geofiber material. Second, Road Oyl should be mixed into the sand-geofiber mix to be used for repairs. Finally, the steel-wheel roller should be used but without vibration.

\section{Behavior of Experimental Items Under Traffic}

\section{Traffic}

Traffic was applied using a M923 5-ton military truck loaded to a gross vehicle weight of $41,600 \mathrm{lb}$ (Photo 79). The individual truck tires were inflated to a 75-psi tire pressure with a contact area of approximately $55.5 \mathrm{in}^{2}$. A total of 500 channelized truck passes were applied to Items 1, 2, and 3. Traffic was 
applied by driving the traffic vehicle (approximately 5 to $10 \mathrm{mph}$ ) over the items, which were oriented in an oval configuration.

\section{Failure criteria}

The failure criteria used in the experiment were based primarily on the development of roughness and excessive mat breakage resulting from subgrade deformation. When the cross section measurements exceeded 3 in., the item was considered failed because of permanent deformation. Failure, as a result of mat breakage, was defined as sufficient breakage to pose a tire hazard during operations. For the purposes of the experiment, mat breakage in excess of 20 percent indicated item failure. It was determined that normal maintenance procedures would include up to 10 percent mat replacement.

\section{Maintenance}

No maintenance was performed on Item 1(MP mats) with the exception of the sand shoulders. The inside shoulder of the MP mat item was eroded due to heavy rains (Photo 80). The eroded shoulder was repaired with sand-geofiber mix (Photo 81). After 25 passes on Item 2, 2- to 3-in. ruts were measured in the Allround hexagonal plastic mats section and 1-in. ruts had developed in the Special hexagonal plastic mat section. After 165 passes, the Allround hexagonal plastic mats were removed due to the severe rutting (4 in.) and disconnection of mats. Once the Allround hexagonal plastic mats were removed, the top 6 in. of the sand layer was pushed from the outside edges to the inside of the section using a D4 dozer. The sand layer was then re-leveled, and a 6-in.-thick layer of crushed limestone (about 100 tons) was placed on top of the sand. The crushed limestone was wet and contaminated with fines. A front-end loader was used to place the crushed limestone in a 20 - $\mathrm{ft}$-wide center section of the roadway. The spreading of the limestone started at the edge of the MP mat item and worked toward the Special hexagonal plastic mat section. After the limestone was placed and spread, it was compacted with 3 coverages of a vibratory steel-wheel roller. After 300 truck passes, the wheel path area in the transition between Special hexagonal mat and $75-\mathrm{ft}$ radius curve section of the sand-geofiber item developed rut depth of 3 in. The deterioration of the transition was filled with geofiberstabilized material from stockpiles (Photo 82). During the traffic period, the outside and inside shoulders of the entire oval field test section were eroded several times due heavy rains. In all case, they were repaired using sandgeofiber.

\section{Rut depth measurements}

Rut depth measurements were recorded at 21 stations throughout the traffic test period. Measurements were made at three locations in each station by placing a metal straightedge across the traffic lane. The maximum rut depth was measured using a folding ruler. The measured rut depth included both the permanent deformation and the upheaval within the traffic lane. Photo 83 shows the straight edge across the ruts in the Allround hexagonal plastic mat section. The average rut depth of each location consisted of the average of the maximum rut depth values from each wheel path. The average of the three locations within each item was recorded as the average rut depth for a given traffic pass level for 
the entire item. The cross section data were normalized (each subsequent measurement was subtracted from baseline data taken at zero passes) to clearly identify the damage due to the applied traffic. Figure 22 presents the average rut depth measurements for Items 1, 2, and 3 at various traffic levels. Table 5 summarizes the detailed rut depth data.

\begin{tabular}{|c|c|c|c|c|c|c|c|}
\hline \multicolumn{8}{|c|}{$\begin{array}{l}\text { Table } 5 \\
\text { Summary of the Rut Depth Measurements }\end{array}$} \\
\hline \multirow{2}{*}{$\begin{array}{c}\text { Number } \\
\text { of } \\
\text { Passes }\end{array}$} & \multicolumn{2}{|c|}{ Hexagonal Mats } & \multicolumn{2}{|c|}{ Multi-Purpose Mats } & \multicolumn{3}{|c|}{ Sand-Fiber Section } \\
\hline & Allround & Special & Straight & $\begin{array}{c}50 \mathrm{ft} \\
\text { Radius }\end{array}$ & $\begin{array}{c}75 \mathrm{ft} \\
\text { Radius }\end{array}$ & $\begin{array}{c}50 \mathrm{ft} \\
\text { Radius }\end{array}$ & Straight \\
\hline 0 & 0.00 & 0.00 & 0.00 & 0.00 & 0.00 & 0.00 & 0.00 \\
\hline 25 & 1.22 & 0.85 & 0.56 & 0.79 & 0.63 & 0.68 & 0.64 \\
\hline 50 & 1.77 & 1.19 & & & & & \\
\hline 75 & 2.29 & 1.40 & & & & & \\
\hline 100 & 2.36 & 1.47 & 0.81 & 0.96 & 1.09 & 1.00 & 0.92 \\
\hline 135 & & & & & & & \\
\hline 165 & 4.79 & 1.36 & & & & & \\
\hline 215 & & 1.99 & & & & & \\
\hline 300 & & 2.36 & 1.36 & 1.41 & 3.08 & 3.27 & 1.90 \\
\hline 335 & & & & & & & \\
\hline 500 & & 5.87 & 1.76 & 1.57 & 4.99 & 5.07 & 3.38 \\
\hline
\end{tabular}

\section{Moisture and density measurements}

Moisture and density measurements were recorded for experiment sections before traffic and following the termination of the traffic test period. Measurements were made using a Troxler 3430 nuclear gage according to the manufacturer's recommendations by certified personnel. Tests were conducted by using the scraper plate to level the test area, hammering the drill rod into the ground, removing the scraper plate, positioning the gauge over the rod hole, and extending the probe to various depths. A 6-in. probe depth was selected for reporting the material properties of experiment sections. The moisture and density data for sections before and after traffic are presented in Table 6 for comparison. A discussion of these results is presented in the Chapter 4 of this report.

\section{Dynamic cone penetrometer (DCP) measurements}

DCP measurements were conducted in experiment sections according to the procedure described in Webster et al. (1992). Three DCP measurements were conducted in each item before traffic was applied. After the termination of traffic, a DCP test was conducted at each station. The test procedure involved placing the DCP cone point on the surface and driving the cone into the ground until the base of the cone was flush with the surface. Then, a baseline measurement was recorded to the nearest $5 \mathrm{~mm}$. The 17.6-lb hammer was then raised and dropped 22.6 in. onto an anvil, which drove the penetrometer rod and cone into the soil. Measurements of the cone's penetration and the corresponding number of hammer blows were recorded approximately every inch $(25 \mathrm{~mm})$ or whenever any noticeable change in penetration rate occurred. A DCP strength index in terms of penetration per hammer blow was calculated for each measurement interval. The DCP index was then converted to CBR percentage using the 
correlation: $\mathrm{CBR}=292 / \mathrm{DCP} 1.12$ where DCP is in $\mathrm{mm} /$ blow. Table 7 summarizes the results of the DCP readings taken from experiment sections. The representative sand subgrade strength for experiment sections ranged from 2 to 12 percent CBR before construction and from 5 to 50 CBR after 500 truck passes. The sand-geofiber strength was approximately a $10 \mathrm{CBR}$ both before and after traffic. A discussion of the DCP test results is presented in the Chapter 4 of this report.

\begin{tabular}{|c|c|c|c|c|c|}
\hline \multicolumn{6}{|c|}{$\begin{array}{l}\text { Table } 6 \\
\text { Summary of Moisture and Density Measurements }\end{array}$} \\
\hline \multicolumn{6}{|c|}{\begin{tabular}{|c|} 
Nuclear Gauge Readings \\
\end{tabular}} \\
\hline \multicolumn{6}{|c|}{ Before Traffic } \\
\hline Location & Section & $\begin{array}{c}\text { Wet } \\
\text { Density } \\
{\mathrm{Ib} / \mathrm{ft}^{3}}^{3}\end{array}$ & $\begin{array}{l}\text { Dry } \\
\text { Density } \\
\text { lb/ft }^{3}\end{array}$ & $\begin{array}{c}\text { Moisture } \\
\mathrm{lb} / \mathrm{ft}^{3}\end{array}$ & $\begin{array}{c}\text { Moisture } \\
\%\end{array}$ \\
\hline 1 & Sand-Fiber & 112.7 & \begin{tabular}{l|l}
109.0 \\
\end{tabular} & 3.7 & 3.4 \\
\hline 2 & Crushed Limestone & 132.3 & 129.5 & 2.7 & 2.1 \\
\hline 3 & Hexagonal Mat & 111.2 & 109.2 & 2.0 & 1.8 \\
\hline 4 & MP Mat & 109.0 & 107.3 & 1.7 & 1.6 \\
\hline \multicolumn{6}{|c|}{ After Traffic } \\
\hline 1 & Sand-Fiber & \begin{tabular}{l|l} 
& 109.6 \\
\end{tabular} & 104.8 & 5.0 & 4.7 \\
\hline 2 & Crushed Limestone & 139.3 & 135.9 & 3.4 & 2.5 \\
\hline 3 & Hexagonal Mat & 122.8 & 112.9 & 8.9 & 7.9 \\
\hline 4 & MP Mat & 122.2 & 116.0 & 6.2 & 5.4 \\
\hline \multicolumn{6}{|c|}{$\begin{array}{l}\text { Notes: } \\
\text { Crushed limestone was constructed after the Allround hexagonal plastic mat failed (165 passes). } \\
\text { The corresponding density and moisture for the Allround hexagonal mat after traffic are as follows: } \\
\text { wet density }=118.4 \mathrm{lb} / \mathrm{ft}^{3} \text {, dry density }=110.4 \mathrm{lb} / \mathrm{ft}^{3} \text {, moisture }=8.0 \mathrm{lb} / \mathrm{ft}^{3} \text {, and moisture }=7.3 \% \text {. }\end{array}$} \\
\hline
\end{tabular}

\begin{tabular}{|c|c|c|c|}
\hline \multicolumn{4}{|c|}{\begin{tabular}{|l} 
Table 7 \\
DCP Results Summary for the Full-Scaled Field Test Section
\end{tabular}} \\
\hline \multicolumn{4}{|c|}{ Average CBR - Before Traffic } \\
\hline Section & Surface Layer & Sand & Dredge \\
\hline Hexagonal Mat & ב... & 4.3 & 10.3 \\
\hline MP Mat & $\ldots$ & 2.9 & 9.0 \\
\hline Sand-Geofiber & 10.2 & 4.5 & 2.2 \\
\hline \multicolumn{4}{|c|}{ Average CBR - After Traffic } \\
\hline Allround Hexagonal Mat & $\ldots$ & 5.7 & 7.5 \\
\hline Special Hexagonal Mat & $\ldots$ & 8.8 & 50.0 \\
\hline MP Mat & $\ldots$ & 9.8 & 20.0 \\
\hline Sand-Geofiber & 10.2 & 10.0 & 4.5 \\
\hline
\end{tabular}

\section{Cross section measurements}

Surface cross sections were recorded at traffic pass intervals throughout the testing period. Rod and level measurements of the cross section were recorded at 1 - $\mathrm{ft}$ intervals across the traffic lane at three locations in each section. These measurements provide an accurate measure of the average maximum permanent deformation. The cross section data were also normalized for analysis purposes. Typical cross section plots for various sections were useful in describing the performance of each section. Figures 23 to 29 show the deformation of each 
section. Table 8 summarizes the permanent surface deformation data for this full-scaled field experiment.

\begin{tabular}{|c|c|c|c|c|c|c|c|}
\hline \multicolumn{8}{|c|}{$\begin{array}{l}\text { Table } 8 \\
\text { Permanent Deformation Measurements for the Full-Scaled Field Test Section }\end{array}$} \\
\hline \multirow[b]{2}{*}{$\begin{array}{l}\text { Number } \\
\text { of Passes }\end{array}$} & \multicolumn{2}{|c|}{ Hexagonal Mats } & \multicolumn{2}{|c|}{ Multi-Purpose Mats } & \multicolumn{3}{|c|}{ Sand-Geofiber Section } \\
\hline & Allround & Special & Straight & $\begin{array}{c}50 \mathrm{ft} \\
\text { Radius }\end{array}$ & $\begin{array}{c}75 \mathrm{ft} \\
\text { Radius }\end{array}$ & $\begin{array}{c}50 \mathrm{ft} \\
\text { Radius }\end{array}$ & Straight \\
\hline 0 & 0.00 & 0.00 & 0.00 & 0.00 & 0.00 & 0.00 & 0.00 \\
\hline 25 & 0.54 & 0.76 & 0.08 & 0.04 & 0.12 & 0.04 & 0.12 \\
\hline 50 & 0.93 & 1.20 & & & & & \\
\hline 75 & 1.20 & 0.92 & & & & & \\
\hline 100 & 1.08 & 0.96 & 0.40 & 0.32 & 0.48 & 0.20 & 0.54 \\
\hline 135 & & & & & & & \\
\hline 165 & 2.49 & 0.96 & & & & & \\
\hline 215 & & 1.52 & & & & & \\
\hline 300 & & 1.92 & 0.84 & 0.56 & 1.16 & 1.64 & 1.26 \\
\hline 335 & & & & & & & \\
\hline 500 & & 3.12 & 1.28 & 1.32 & 1.64 & 2.04 & 1.92 \\
\hline
\end{tabular}




\section{Analysis of Field Experiment}

The following analysis is based solely on the performance of the roadway systems under the test conditions presented in this report. The tests did not include braking traffic conditions.

\section{Material Performance}

A summary of the performance of Items 1, 2, and 3 is presented in Table 9.

\section{Post traffic condition}

The sand-geofiber and MP mat items provided adequate structural support to withstand the application of 500 truck passes with no maintenance. In summary, all of the experiment sections performed adequately with the exception of the Allround hexagonal plastic mat. Photos 83 and 84 show the post traffic condition of Allround hexagonal plastic mat section of Item 2. This section was designed to evaluate the performance of the Allround hexagonal plastic mats in a 50 - $\mathrm{ft}$ radius curve. After 165 passes, it was in poor condition, and the mats separated at several locations. Mats were hitting the truck's rear end differential as it moved across the section. At station $1+05$, the rut depth was 12 in.

\section{Item 1: Multi-Purpose Mats}

Straight section. This section reached an average permanent deformation of 1.28 in. after 500 truck passes. The mat and connector pins performed well. One panel was slightly damaged, and one pin was loose. After 300 truck passes, the section moved about 8 in toward traffic direction. Photo 85 shows a total displacement of $12 \mathrm{in}$. on the straight section after 500 truck passes. One connector pin was not properly tightened and became disconnected after 500 passes (Photo 86). One MP mat delaminated at the downward fold edge as shown Photo 87. The anchor performed well once it locked itself as shown in Photo 88.

50-ft radius curve. This section had an outside and inside radius of $74 \mathrm{ft}$ and $50 \mathrm{ft}$, respectively. The section provided excellent structural support throughout the traffic period. The permanent deformation for this section was 
1.32 in. after 500 truck passes. The section moved approximately 2 in. laterally after the test traffic (Photo 89). Mats, connector pins, and anchors were in excellent conditions after the 500 passes.

\begin{tabular}{|c|c|c|c|c|}
\hline \multicolumn{5}{|c|}{$\begin{array}{l}\text { Table } 9 \\
\text { Performance Summary }\end{array}$} \\
\hline Roadway System & $\begin{array}{l}\text { Traffic } \\
\text { Passes }\end{array}$ & $\begin{array}{l}\text { Permanent } \\
\text { Deformation } \\
\text { in. }\end{array}$ & Performance & Comments \\
\hline $\begin{array}{l}\text { Item } 1 \text { (Multi-Purpose } \\
\text { Mats Straight Section) }\end{array}$ & 500 & 1.28 & Excellent & $\begin{array}{l}\text { Suitable for } 5 \text {-ton military truck traffic } \\
\text { over loose sand }\end{array}$ \\
\hline $\begin{array}{l}\text { Item } 1 \text { (Multi-Purpose } \\
\text { Mats } 50 \text {-ft Radius Curve } \\
\text { Section) }\end{array}$ & 500 & 1.32 & Excellent & $\begin{array}{l}\text { Suitable for } 5 \text {-ton military truck traffic } \\
\text { over loose sand. }\end{array}$ \\
\hline $\begin{array}{l}\text { Item } 2 \text { (Allround } \\
\text { Hexagonal Plastic Mat) }\end{array}$ & 165 & 2.49 & Poor & $\begin{array}{l}\text { In previous studied, the Allround mats } \\
\text { performed good in straight section. } \\
\text { This section had a } 50-\mathrm{ft} \text { radius curve } \\
\text { and mats disconnected. }\end{array}$ \\
\hline $\begin{array}{l}\text { Item } 2 \text { (Special } \\
\text { Hexagonal Plastic Mat) }\end{array}$ & 500 & 3.12 & Poor & $\begin{array}{l}\text { The Special mats performed poor in } \\
\text { straight section but extensive ruts were } \\
\text { observed. }\end{array}$ \\
\hline $\begin{array}{l}\text { Item } 3 \text { (Sand-Geofiber } \\
70 \text {-ft Radius Curve } \\
\text { Section) }\end{array}$ & 500 & 1.64 & Excellent & $\begin{array}{l}\text { Suitable for } 5 \text {-ton military truck traffic } \\
\text { over loose sand with maintenance after } \\
500 \text { passes. }\end{array}$ \\
\hline $\begin{array}{l}\text { Item } 3 \text { (Sand-Geofiber } \\
50 \text { - } \mathrm{ft} \text { Radius Curve } \\
\text { Section) }\end{array}$ & 500 & 2.04 & Excellent & $\begin{array}{l}\text { Suitable for } 5 \text {-ton military truck traffic } \\
\text { over loose sand with maintenance after } \\
500 \text { passes. }\end{array}$ \\
\hline $\begin{array}{l}\text { Item } 3 \text { (Sand-Geofiber } \\
\text { Straight Section) }\end{array}$ & 500 & 1.92 & Excellent & $\begin{array}{l}\text { Suitable for } 5 \text {-ton military truck traffic } \\
\text { over loose sand. }\end{array}$ \\
\hline
\end{tabular}

\section{Item 2: Hexagonal Plastic Mats}

Allround hexagonal plastic mat section. The Allround hexagonal plastic mats section had an outside and inside radius of $74-\mathrm{ft}$ and $50-\mathrm{ft}$, respectively. These mats were previously tested on straight sections and performed excellent. The performance of this mat under $50-\mathrm{ft}$ radius curves was poor as indicated by 2.49 in. average permanent deformation after 165 truck passes. The maximum permanent deformation was 12 in., therefore, the traffic was discontinued and item was replaced. The mats were removed since the mats were hitting the truck's axles. Forty-two mats were damaged as shown Photos 90 and 91. The mats disconnected at the upheaval and center lane areas. The poor bearing capacity of the loose sand, shear forces caused by truck tires, and poor mat connection mechanisms unzipped the mats in these areas (Photo 92). To maintain trafficability of the field test section, the Allround hexagonal mat section was replaced with a 6 in. layer of crushed limestone.

Special hexagonal plastic mat section. This mat was tested for the first time in this experiment on a straight section. This section supported 500 truck passes with a 3.12-in. average permanent deformation. The special hexagonal mats section moved approximately $7 \mathrm{in}$. toward the direction of traffic after the Allround hexagonal mat section was removed (Photo 93). Mats became 
disconnected in the wheel path. Since the truck axles were hitting the mats, several mats broke as shown Photo 94.

\section{Item 3: Sand-Geofiber Stabilized Sections}

75-ft radius curved section. This section had an inside and outside radius of $75 \mathrm{ft}$ and $99 \mathrm{ft}$, respectively. The performance of this section was excellent as indicated the 1.64 in. of average permanent deformation after 500 truck passes.

50-ft radius curved section. This curved section had an inside and outside radius of $50 \mathrm{ft}$ and $74 \mathrm{ft}$, respectively. The performance of this curve was good as indicated the 2.04 in. of permanent deformation after 500 truck passes.

Straight section. The sand-geofiber was tested in straight sections in previous studies and performed excellent. The performance of this section was excellent as indicated by the $1.92 \mathrm{in}$. of average permanent deformation after 500 truck passes.

\section{Field Data}

Moisture and density data. Moisture and density data were collected from the centerline and the wheel paths. A summary of the data is presented in Table 6. A comparison of the densities measured before traffic to those measured after traffic indicates that the sand and crushed limestone layers experienced significant densification under the applied traffic. The densities of the sand layer were consistent along three items. The sand-geofiber showed less density due the loss of geofiber reinforcement at the wheel paths. The moisture content measurements were higher after traffic due to heavy rains. The sandgeofiber moisture content was higher before traffic but lower after traffic.

DCP data. DCP measurements were made in several locations along the sections. These data were converted to CBR as described previously, and the average CBRs for selected pavement layers are presented in Table 7. A comparison of the DCP values before and after traffic also indicates that strength increases after traffic. This could be attributed to sand-geofiber layer densification.

\section{Installation Rates}

During the construction of the oval field test section, temperatures ranged from 78 to 95 degrees Fahrenheit, the humidity ranged from 50 to 87 percent, and heat index ranged from 80 to 105 degrees Fahrenheit. For the MP mat item, the construction crew consisted of six men including an equipment operator. The total roadway area and construction time were $5,148 \mathrm{ft}^{2}$ and $203 \mathrm{~min}$, respectively. The installation rate for the MP mat item was $253 \mathrm{ft}^{2}$ per man-hour. For the Allround hexagonal plastic mat section, eight men installed the mats. The 
section area was $2,340 \mathrm{ft}^{2}$. The construction time was $30 \mathrm{~min}$. The installation time for the Allround hexagonal plastic mat was $585 \mathrm{ft}^{2}$ per man-hour. For the Special hexagonal plastic mat section, eight men installed the mats. The section area was $1,259 \mathrm{ft}^{2}$. The construction time was $12 \mathrm{~min}$. The installation time for the Special hexagonal plastic mat was $786 \mathrm{ft}^{2}$ per man-hour. For the sandgeofiber item, an average of 5 men constructed the item. The item area was $6,800 \mathrm{ft}^{2}$. The construction time was $6.5 \mathrm{hr}$. The installation time for the sandgeofiber item was $209 \mathrm{ft}^{2}$ per man-hour. 


\section{Conclusions and Recommendations}

\section{Conclusions}

The following conclusions were noted:

a. Item 1: The MP mats provided adequate structural support to sustain 500 passes of the 5-ton military truck in both the straight and 50- $\mathrm{ft}$ radius curved section.

$b$. Item 1: The aluminum connector pins withstood flexures of the mat in excess of 3 in. The alignment tools were useful to align the mat holes and to install the connector pins. The anchors helped to stabilize the mats during turning maneuvers once the cable stressed.

c. Item 2: The Allround hexagonal plastic mats provided poor load support for 5-ton truck traffic. The Allround hexagonal mats performed extremely poor under a 50 - $\mathrm{ft}$ radius curved section. The mats disconnected creating a dangerous roadway for the truck.

d. Item 2: The Special hexagonal plastic mats provided adequate support for 500 truck passes in a straight section, but the mats disconnected at the centerline of the lane and at the upheaval areas at the edge of the wheel paths.

e. Item 3: Sand-geofiber stabilization is adequate for straight and curved roadway sections. The $75-\mathrm{ft}$ and $50-\mathrm{ft}$ radius curved sand-geofiber sections were adequate to sustain 500 military truck passes over 24-in. layer of loose sand.

$f$. Item 3: The selected fiber content of 0.8 percent per dry weight of sand provided adequate support to withstand the applied traffic.

g. Item 3: The 8 in. stabilized sand layer provided adequate support for 500 passes of the 5 -ton military truck.

$h$. The MP mats, hexagonal plastic mats (in straight section), and sandgeofiber stabilized technologies were confirmed as adequate alternatives to traditional road construction technologies. These technologies were exposed to heavy rains, humidity, winds, and high and low temperatures for a period of 6 months. 
i. For the MP mat item, the installation rate was $253 \mathrm{ft}^{2}$ per man-hour. The installation time for the Allround hexagonal plastic mat was $585 \mathrm{ft}^{2}$ per man-hour. The installation time for the Special hexagonal plastic mat was $786 \mathrm{ft}^{2}$ per man-hour. The installation time for the sand-geofiber item was $209 \mathrm{ft}^{2}$ per man-hour.

\section{Recommendations}

The performance of MP mats and sand-geofiber stabilization during traffic testing indicate the potential for excellent field performance when used over loose sand conditions. However, the tests conducted did not include the effects of braking. A field demonstration is required to transfer the technology from the field investigation to the warfighter while monitoring materials performance under actual field conditions.

The MP mats and sand-geofiber stabilization technology are recommended for roadway construction because they are not logistic intensive, and cheaper than other potential mat surfacings. The Allround and Special hexagonal plastic mats are recommended for parking, storage, walkways, tent flooring, and lowdensity traffic areas.

The results of this study demonstrated great potential for military road applications using the MP mats and sand-geofiber technologies. The effect of tracked vehicles on mat deterioration requires additional investigation. 


\section{References}

American Society for Testing and Materials. (1992). "Standard classification of soils for engineering purposes (Unified Soil Classification System),"

Designation: D 2487, Philadelphia, PA.

(1993). "Standard test methods for maximum index density and unit weight of soils using a vibratory table," Designation: D 4253, Philadelphia, PA.

(1998). "Standard test method for flexural properties of unreinforced and reinforced Plastics and electrical insulating materials by four-point bending," Designation: D 6272, Philadelphia, PA.

. (1998). "Standard test method for tensile properties of polymer matrix composite materials," Designation: D 3039, Philadelphia, PA.

Department of Defense. (1988). Joint Chiefs of Staff. (1998). "Joint Tactics, Techniques, and Procedures for Joint Logistics Over-the-Shore (JLOTS)," JP 4-01.6, Washington, DC.

Geotechnical Fabrics Report, GFR. (1998). "Specifier's guide 1999," GFR, Industrial Fabrics Association International, Roseville, MN.

GFI. (1996). "Technical Proposal - Solicitation Number DACA 39-96-R0003," GFR, Industrial Fabrics Association International, Roseville, MN.

Tingle, Jeb S., Webster, Steve L., and Santoni, Rosa L. (1999). "Discrete fiber reinforcement of sands for expedient road construction," Technical Report GL-99-3, U.S. Army Engineer Waterways Experiment Station, Vicksburg, MS.

Tingle, Jeb S. and Webster, Steve L. (1998). "Expedient Road Construction Over Sands Using Lightweight Mats," Technical Report GL-98-3, U.S. Army Engineer Waterways Experiment Station, Vicksburg, MS.

Webster, Steve L. (1986). "Sand-grid demonstration roads constructed for JLOTS II tests at Fort Story, Virginia," Technical Report GL-86-19, U.S. Army Engineer Waterways Experiment Station, Vicksburg, MS. 
Webster, Steve L., and Santoni, Rosa L. (1997). "Contingency airfield and road construction using geosynthetic fiber stabilization of sands," Technical Report GL-97-4, U.S. Army Engineer Waterways Experiment Station, Vicksburg, MS.

$\underline{\text { www.GFIinc.us }}$

www.earthanchor.com 


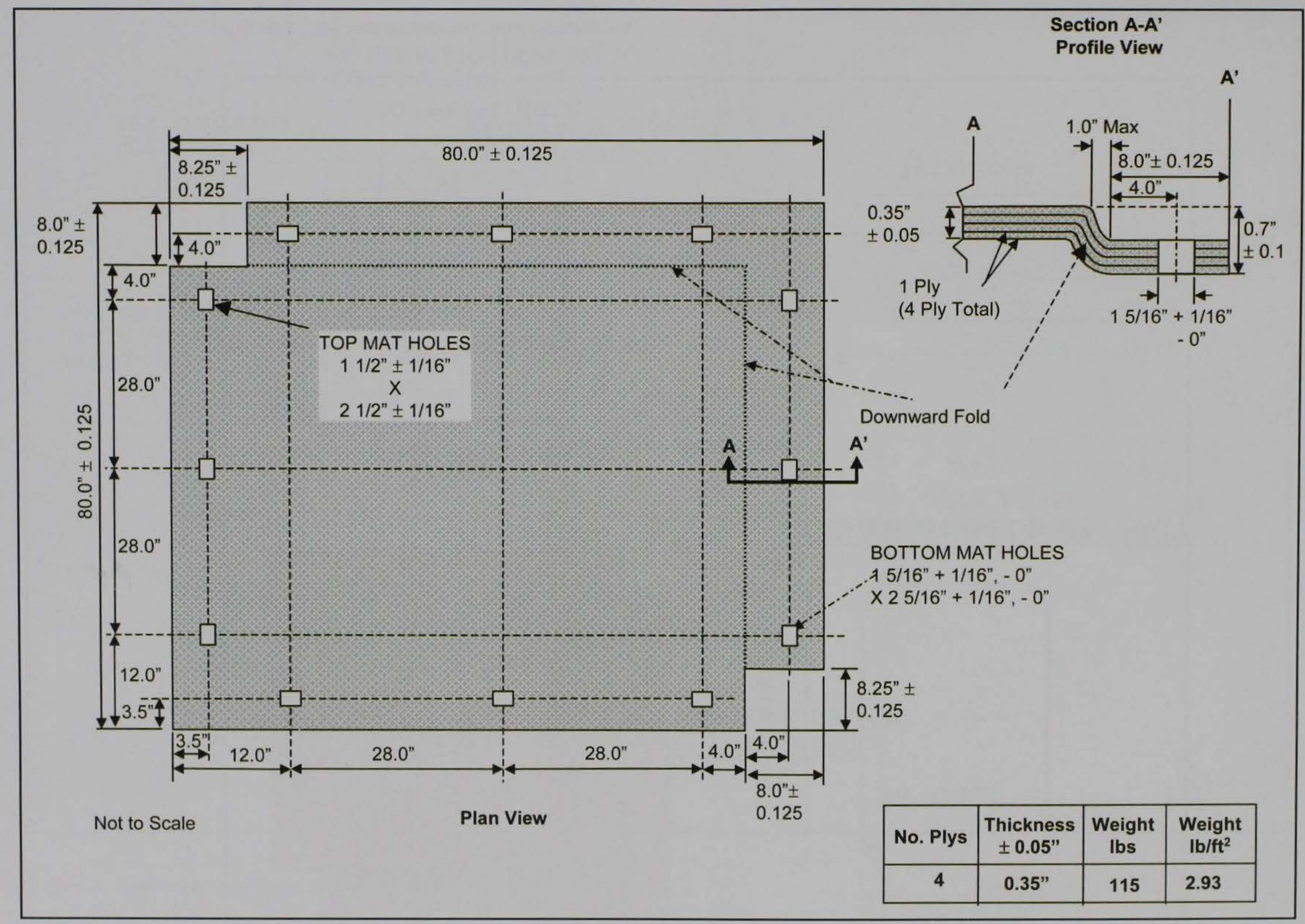

Figure 1. MP mat dimensions 


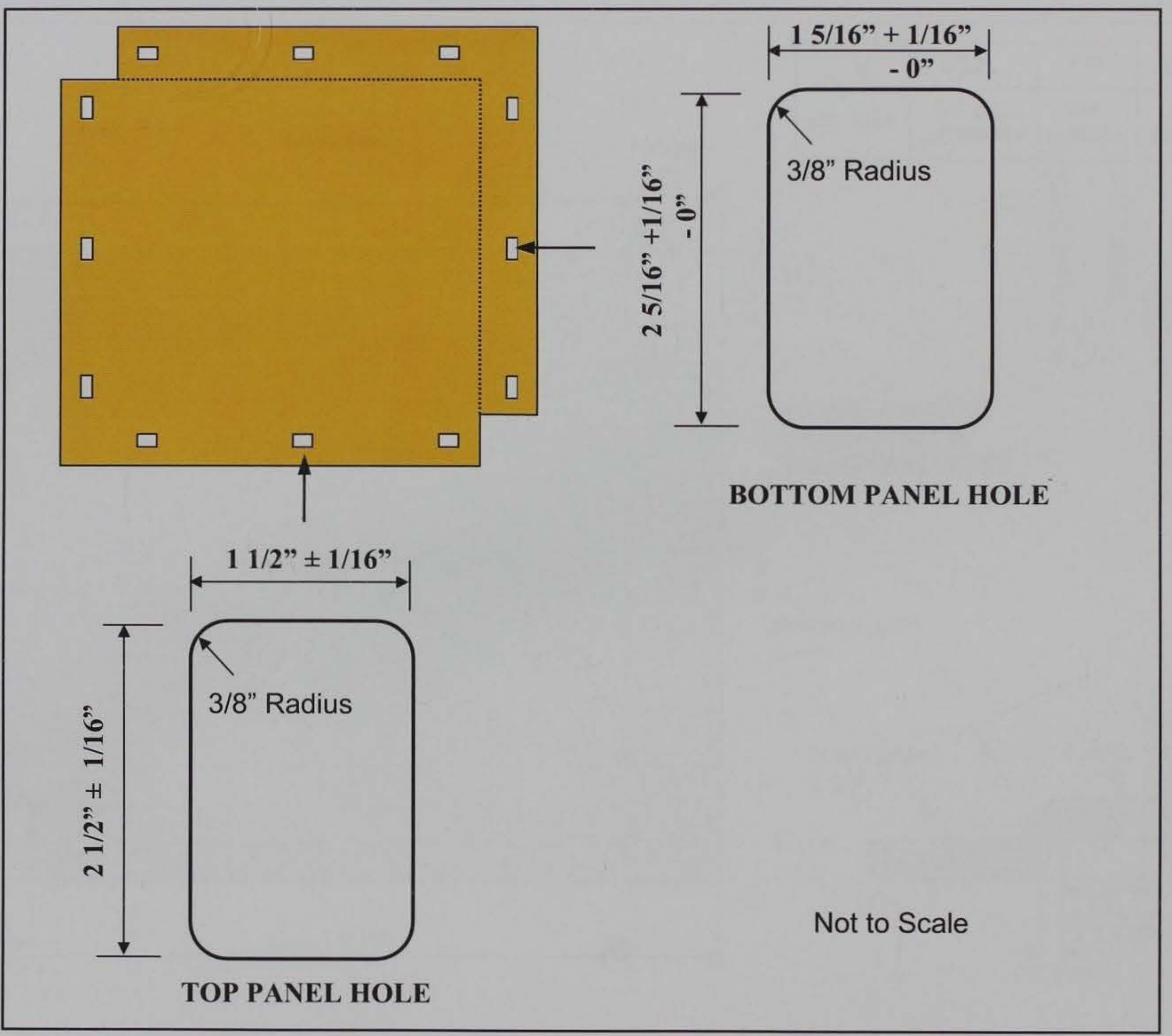

Figure 2. MP mat rectangular hole dimensions 


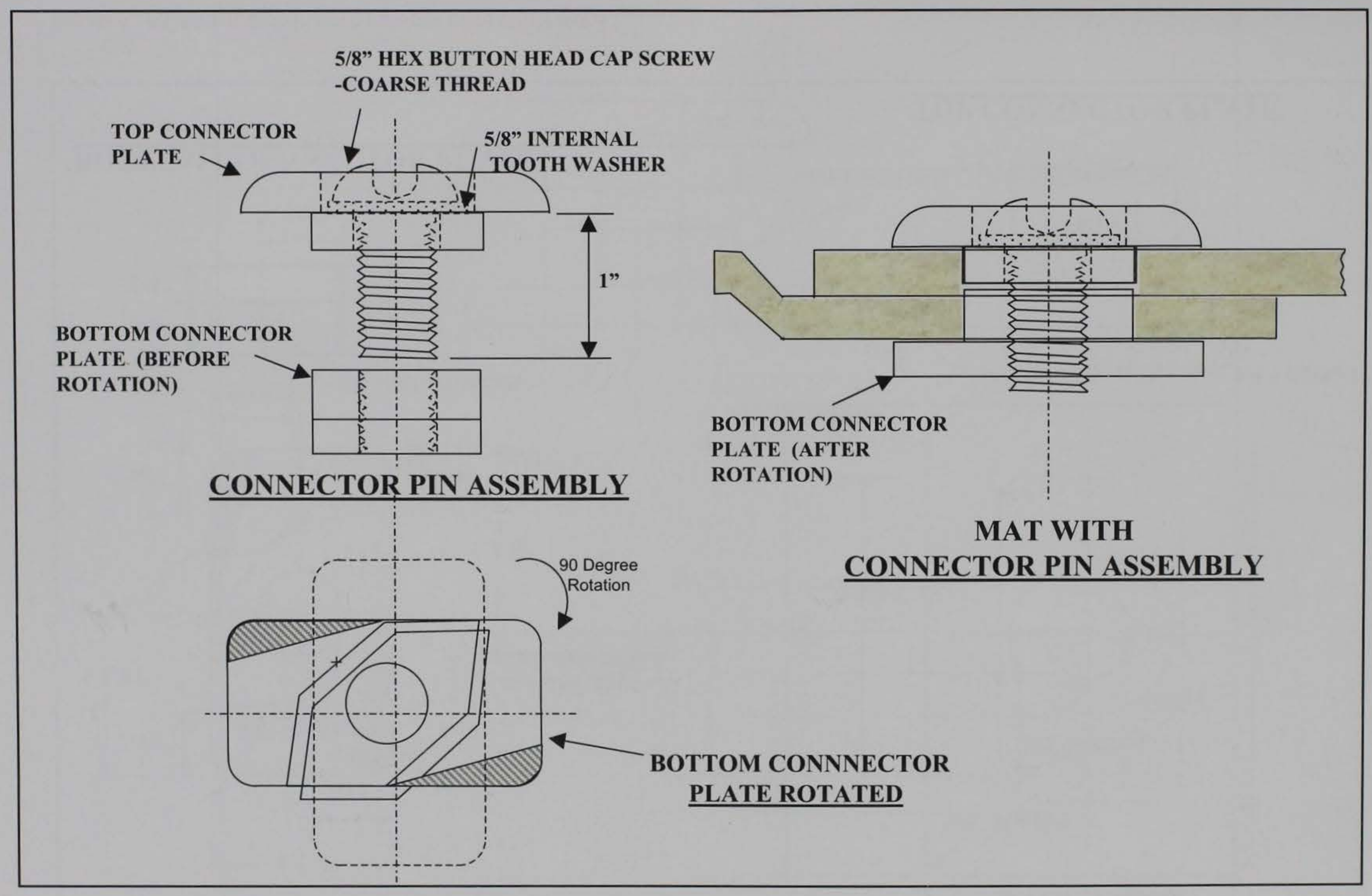

Figure 3. Aluminum drop-in pin connector assembly 


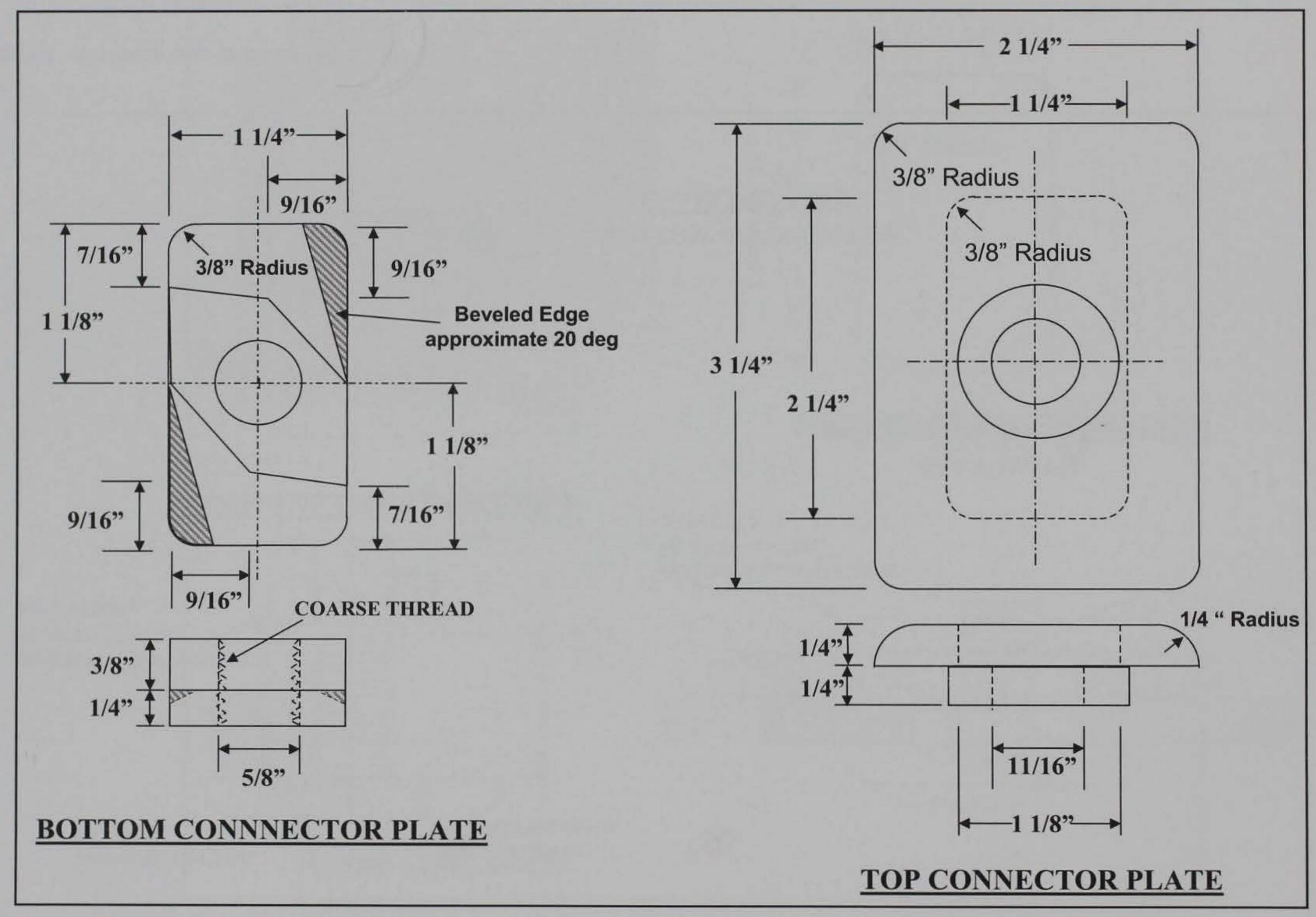

Figure 4. Aluminum drop-in pin connector plate dimensions 


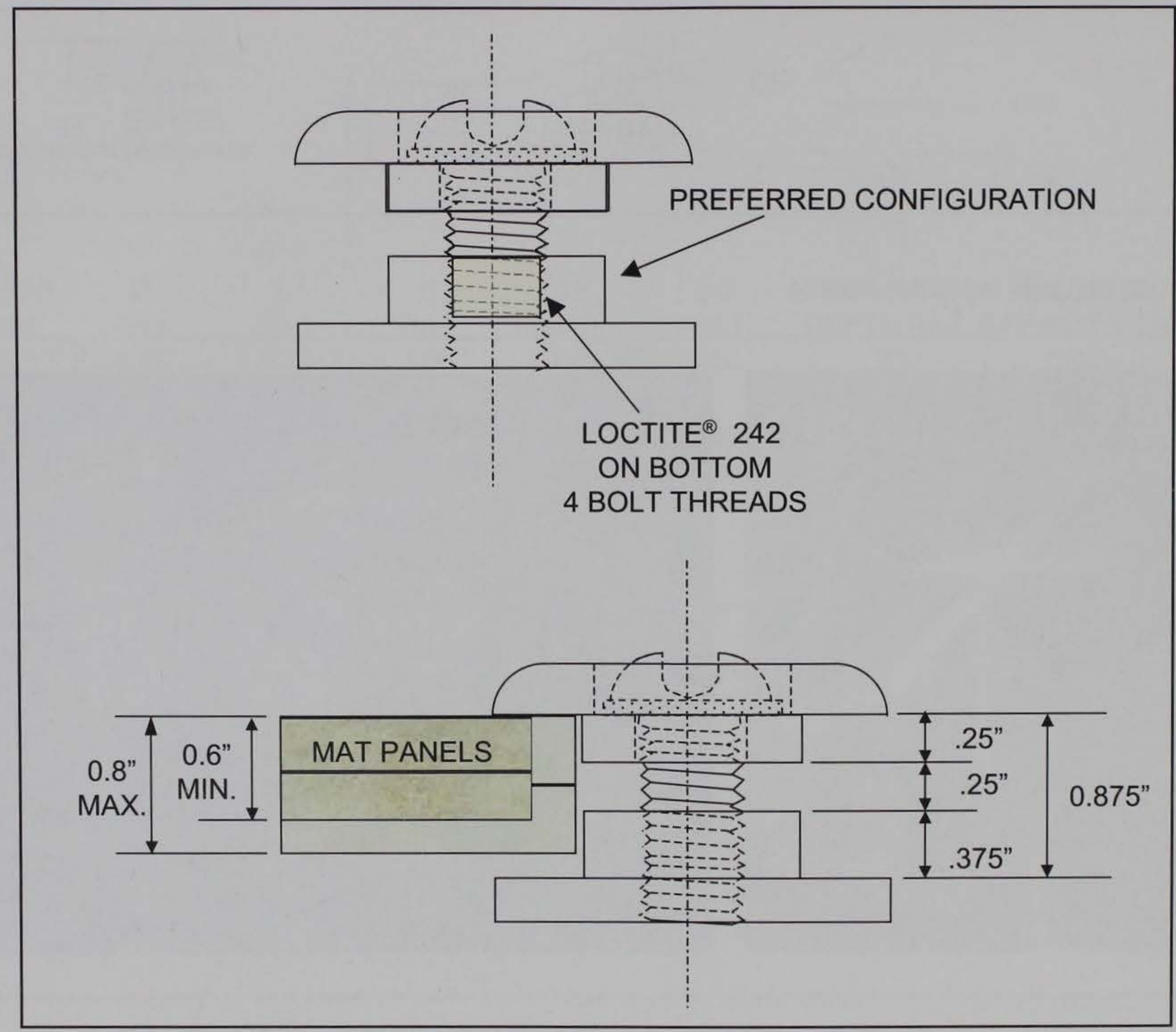

Figure 5. Aluminum drop-in pin connector configurations for locking bottom connector plate to cap screw and tolerance ranges 


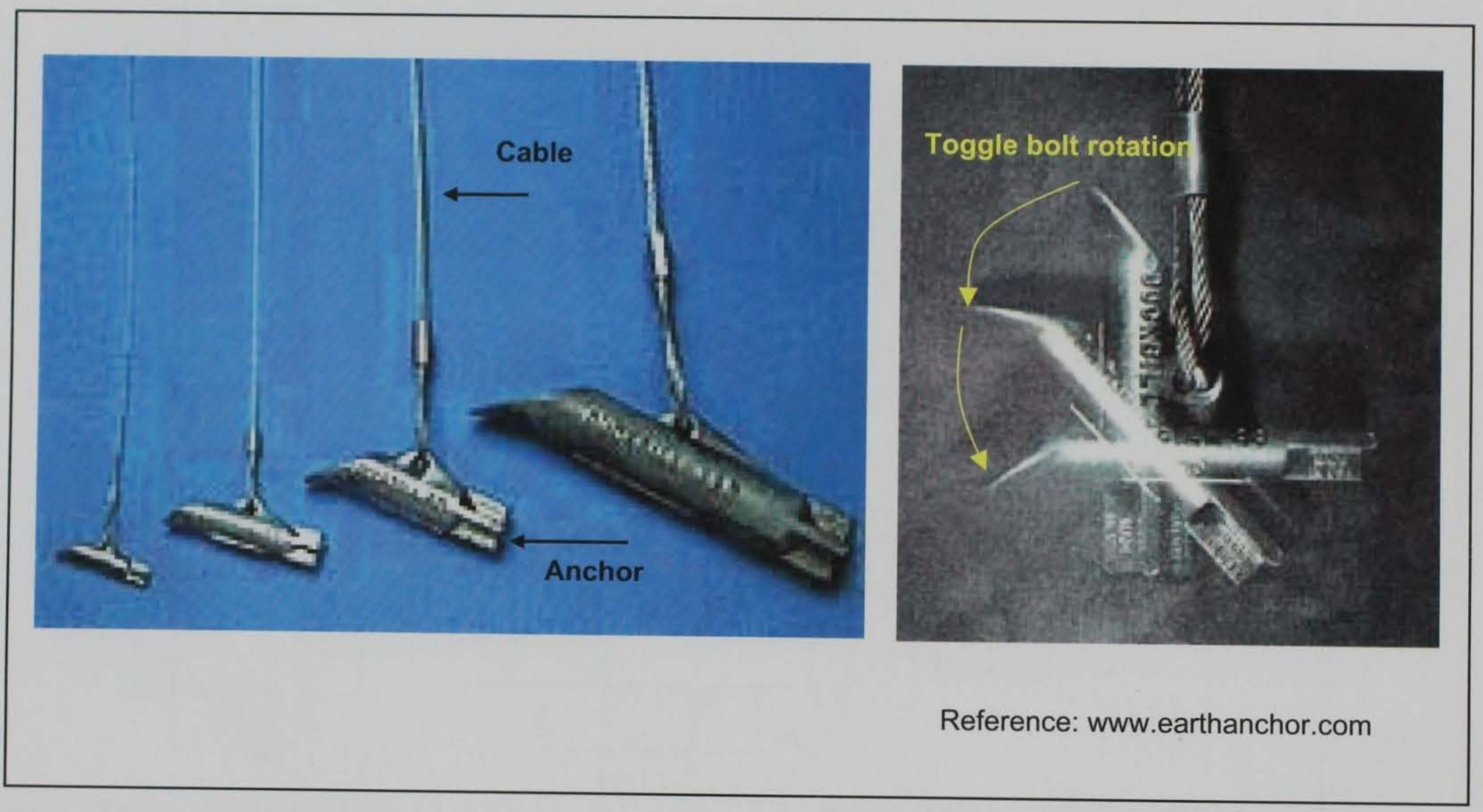

Figure 6. Duckbill anchor components 


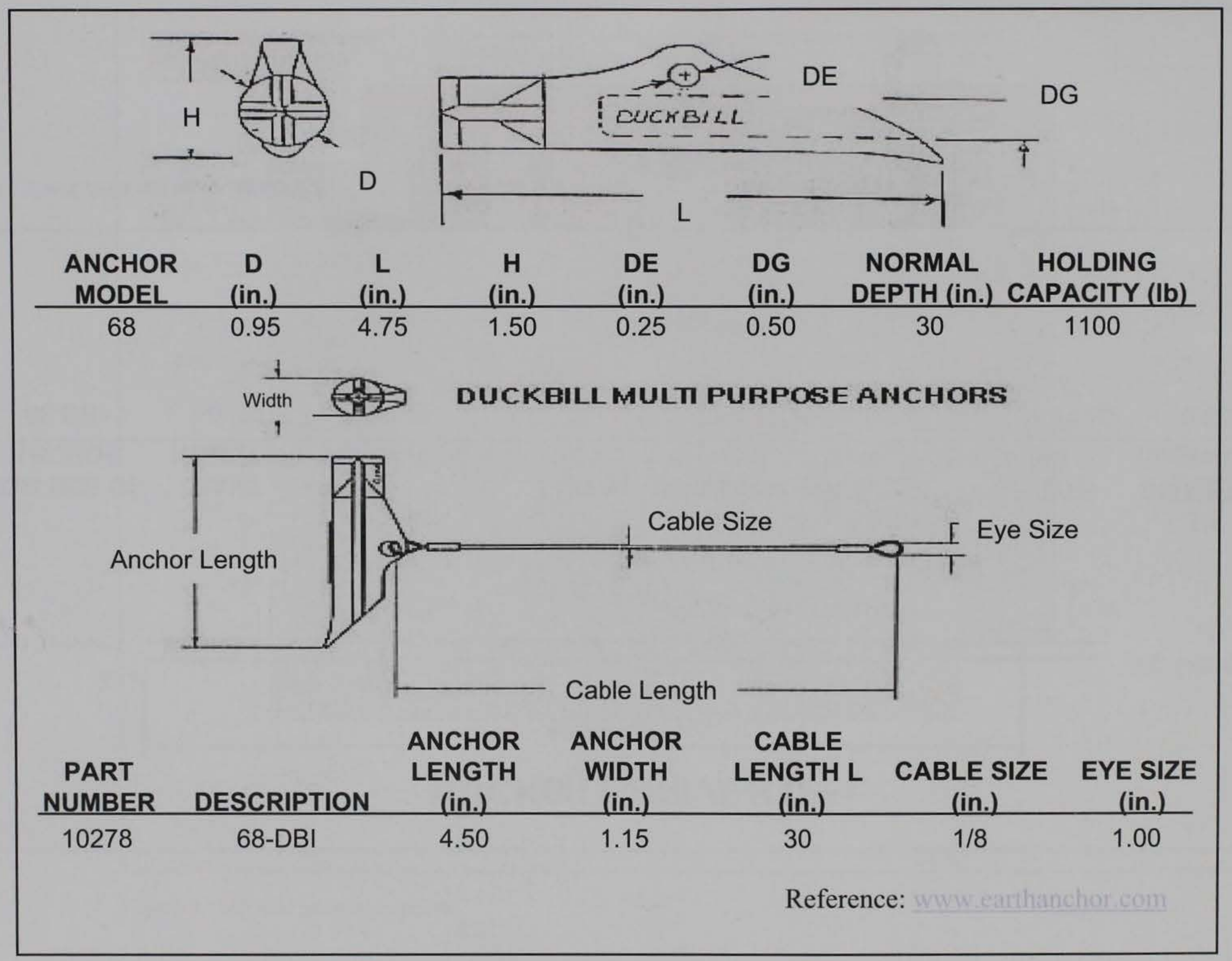

Figure 7. Duckbill anchor dimensions 


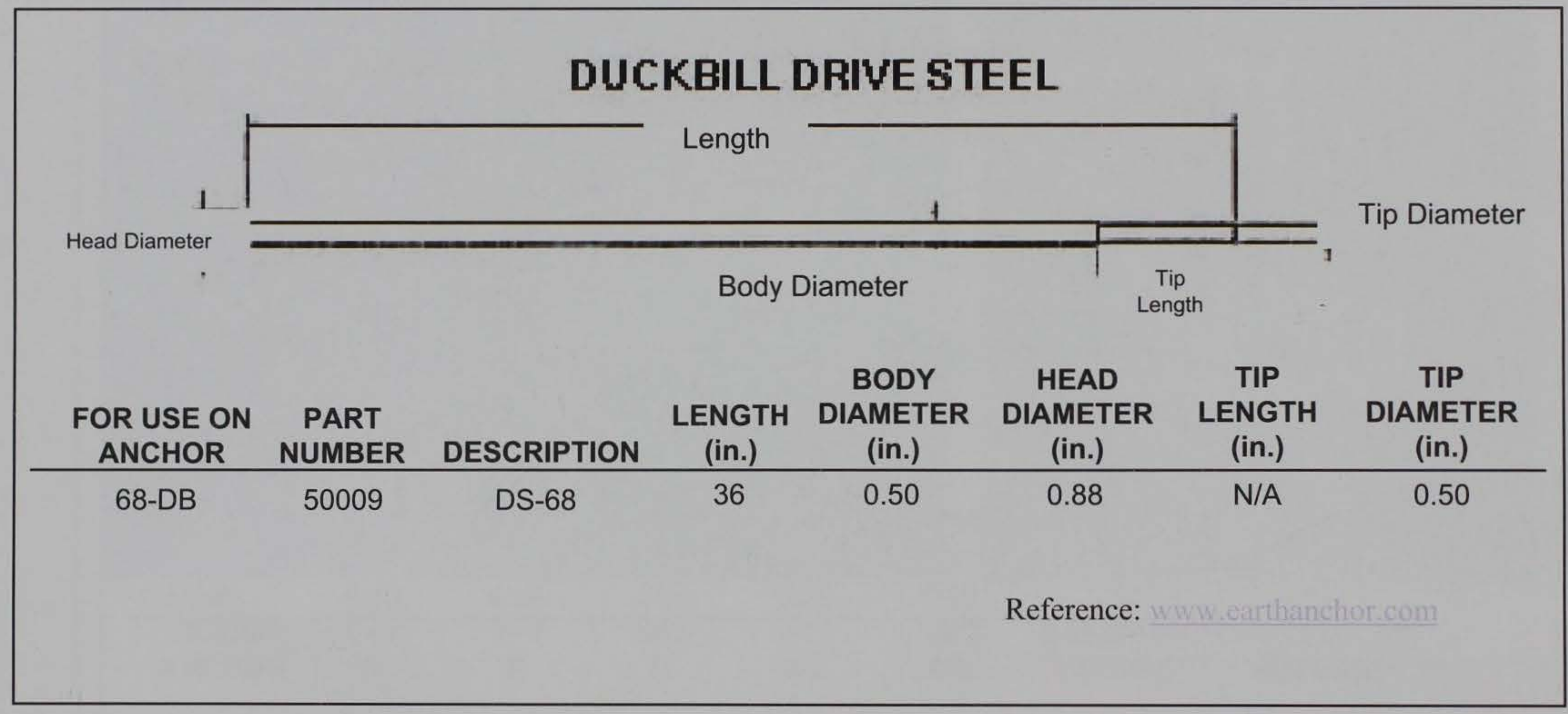

Figure 8. Steel drive rod basic dimensions 


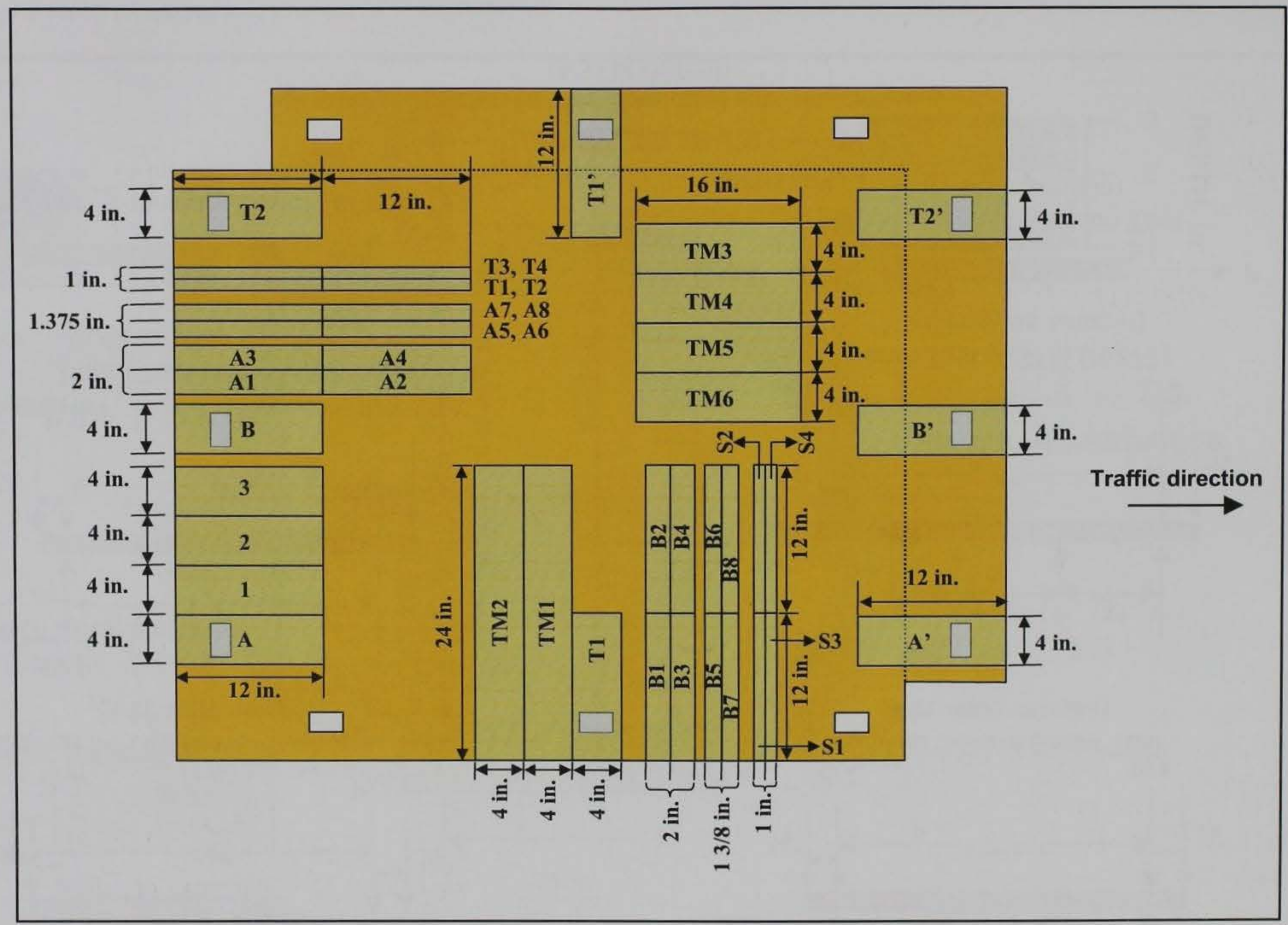

Figure 9. MP mat sample locations 


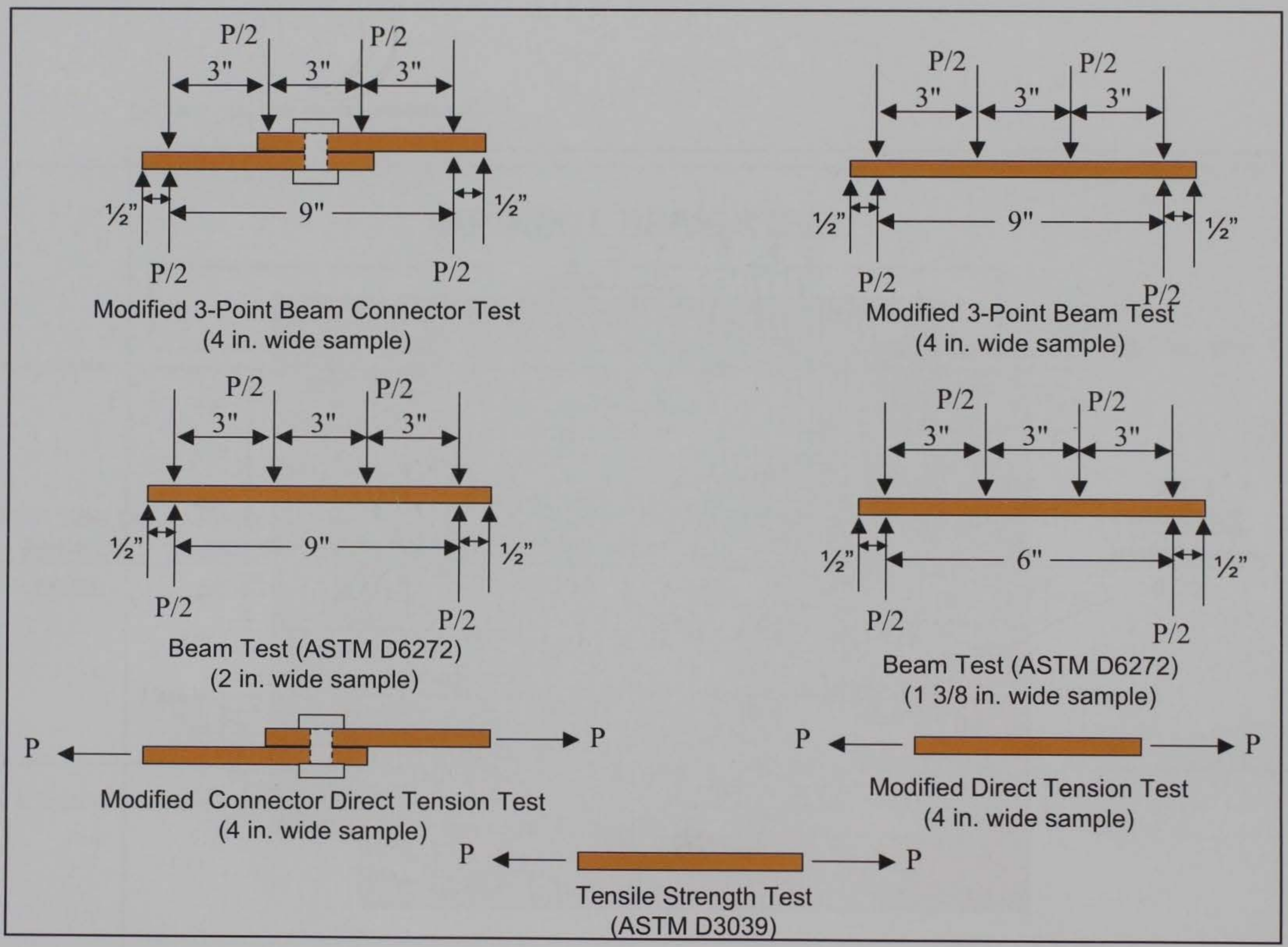

Figure 10. Test set up for the MP mat samples 


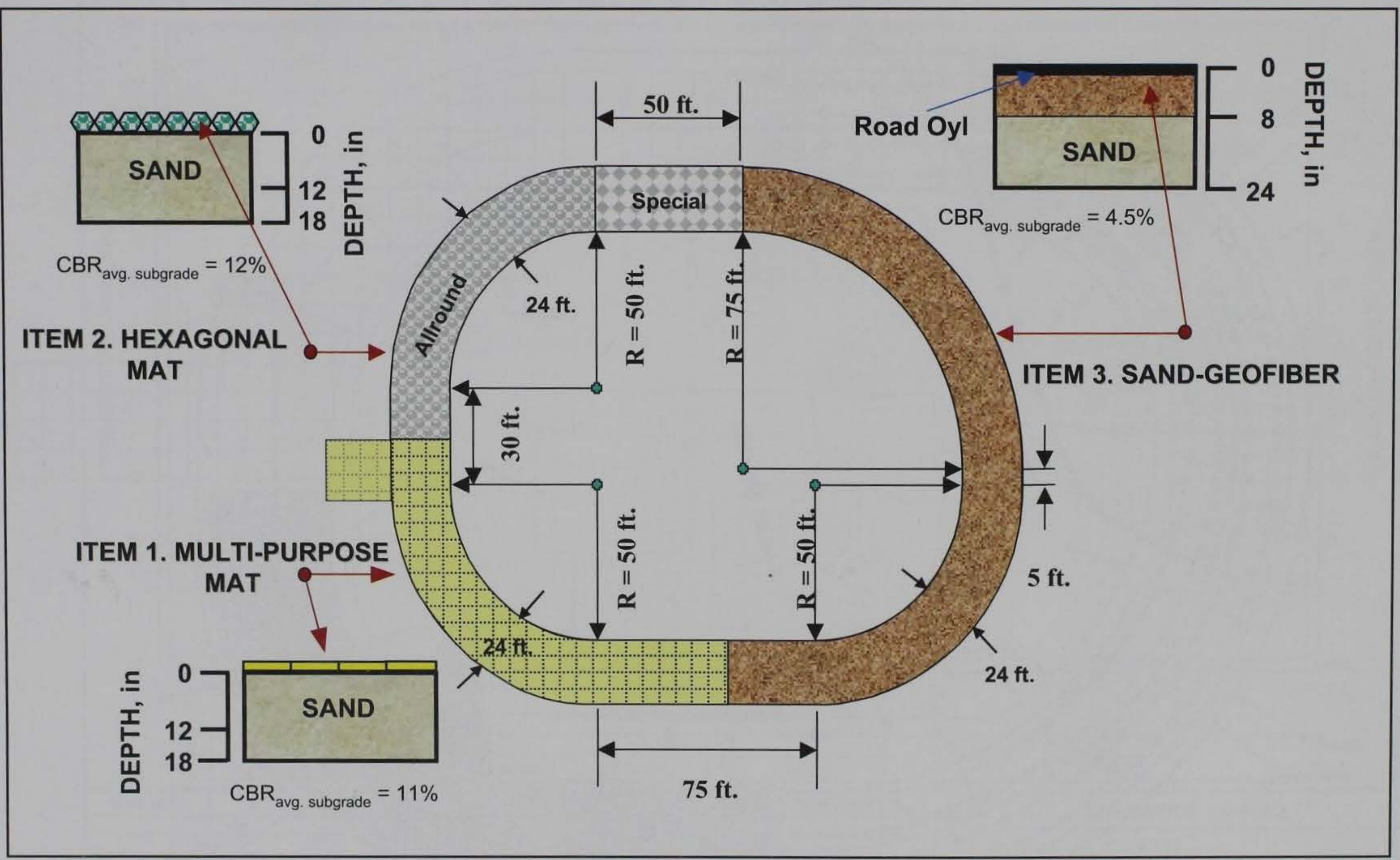

Figure 11. Full-scale field test section plan and profile view 


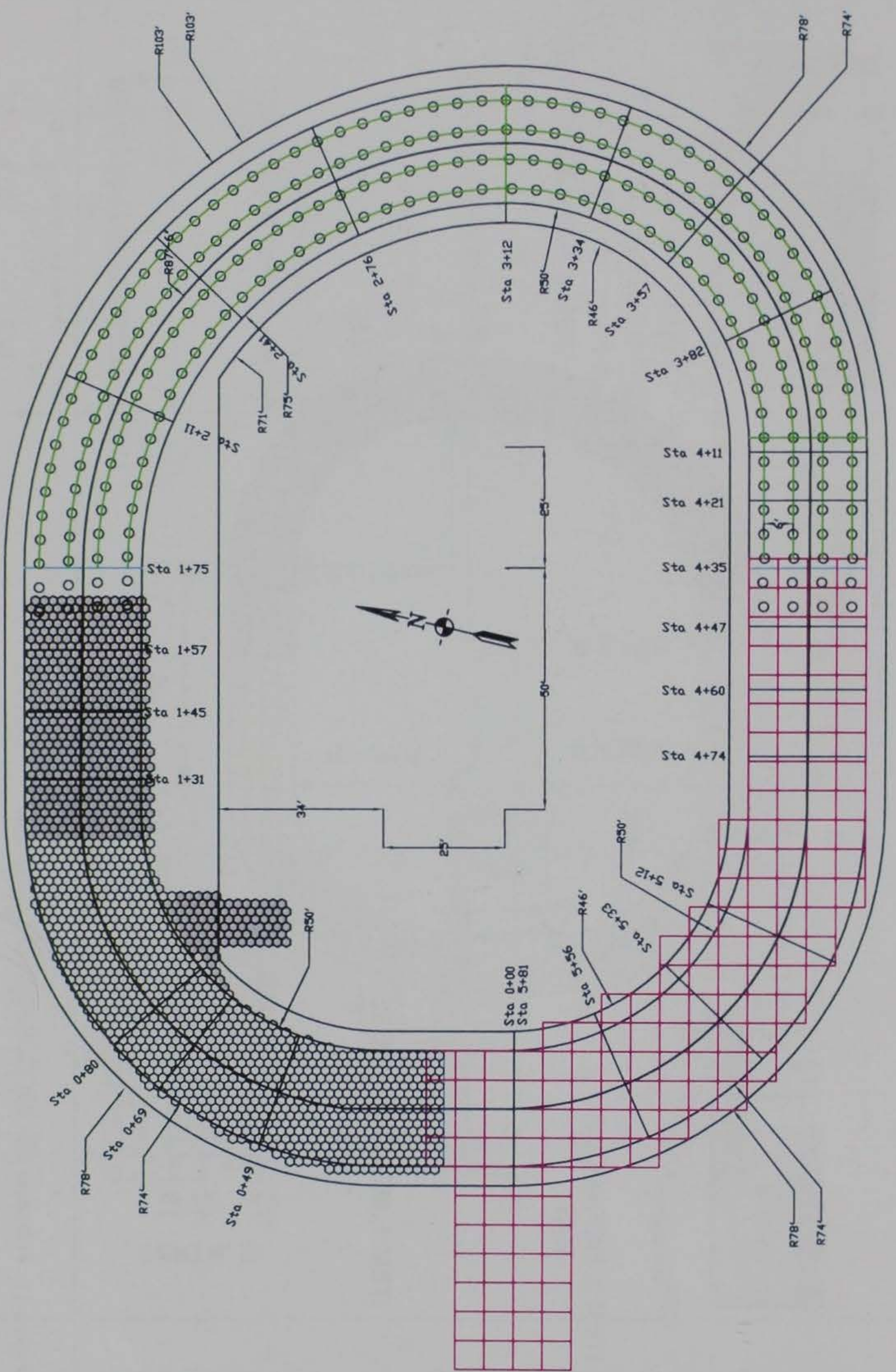

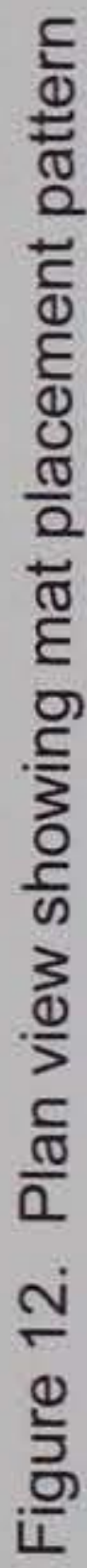




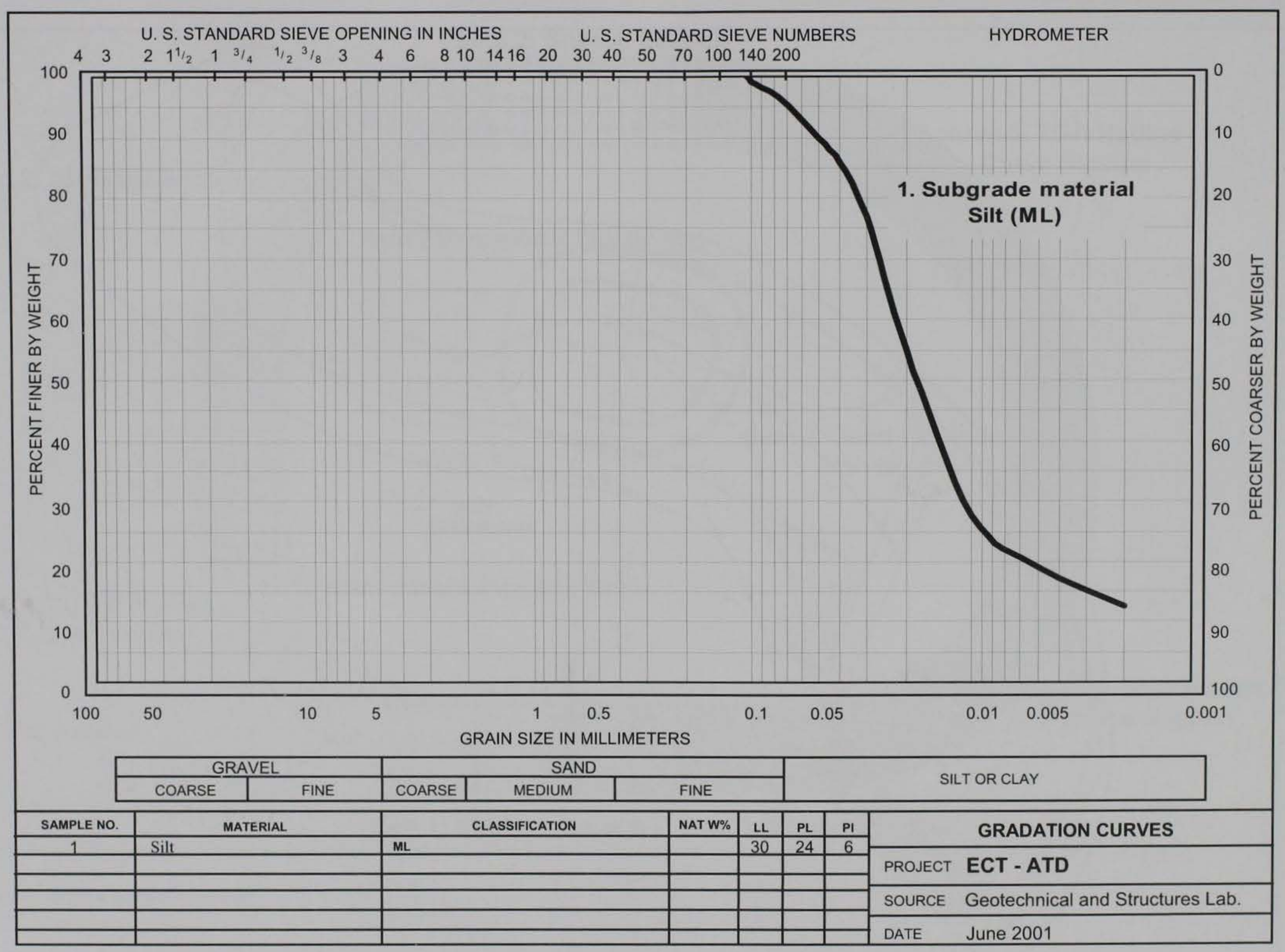

Figure 13. Classification data and gradation curve for dredge material 


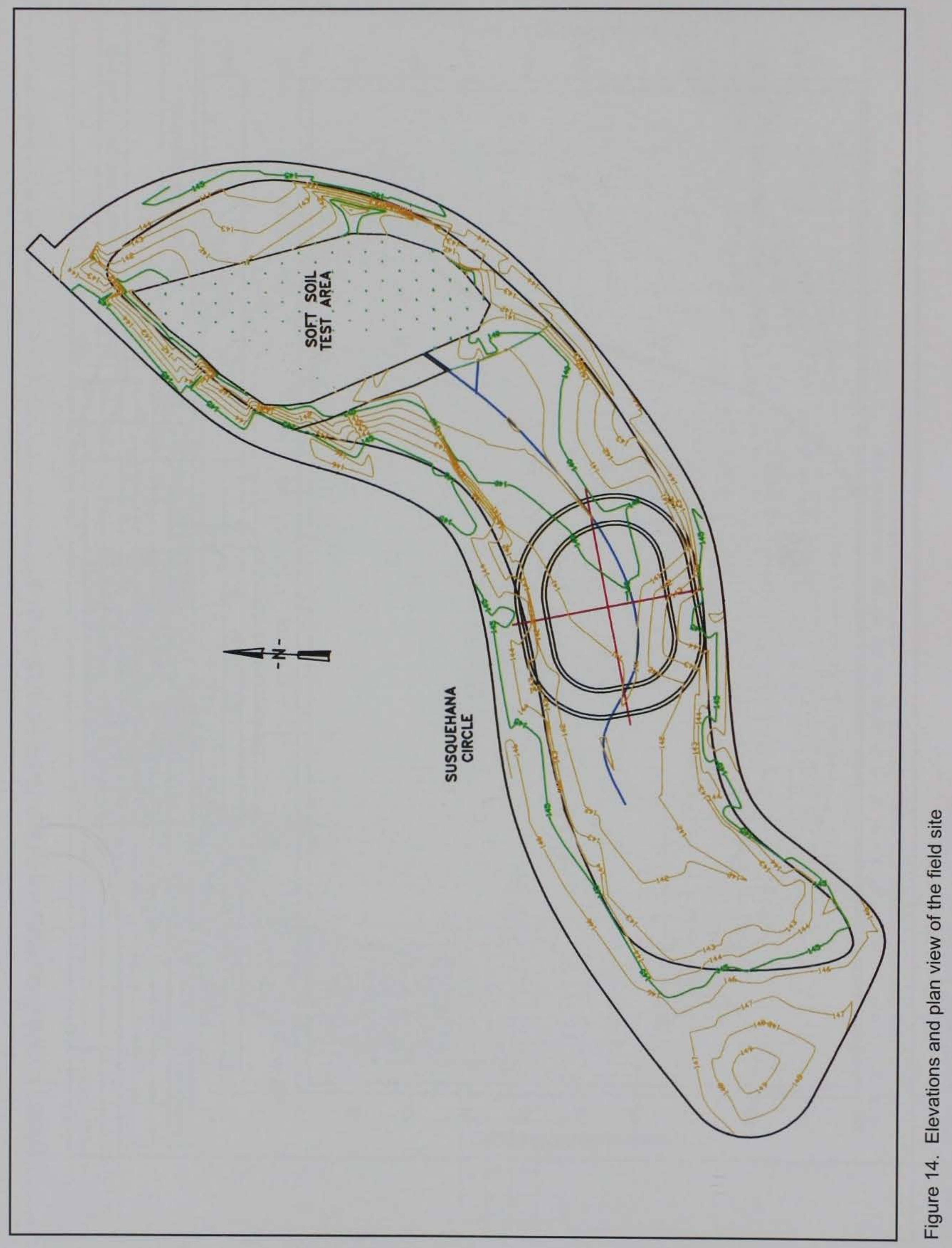




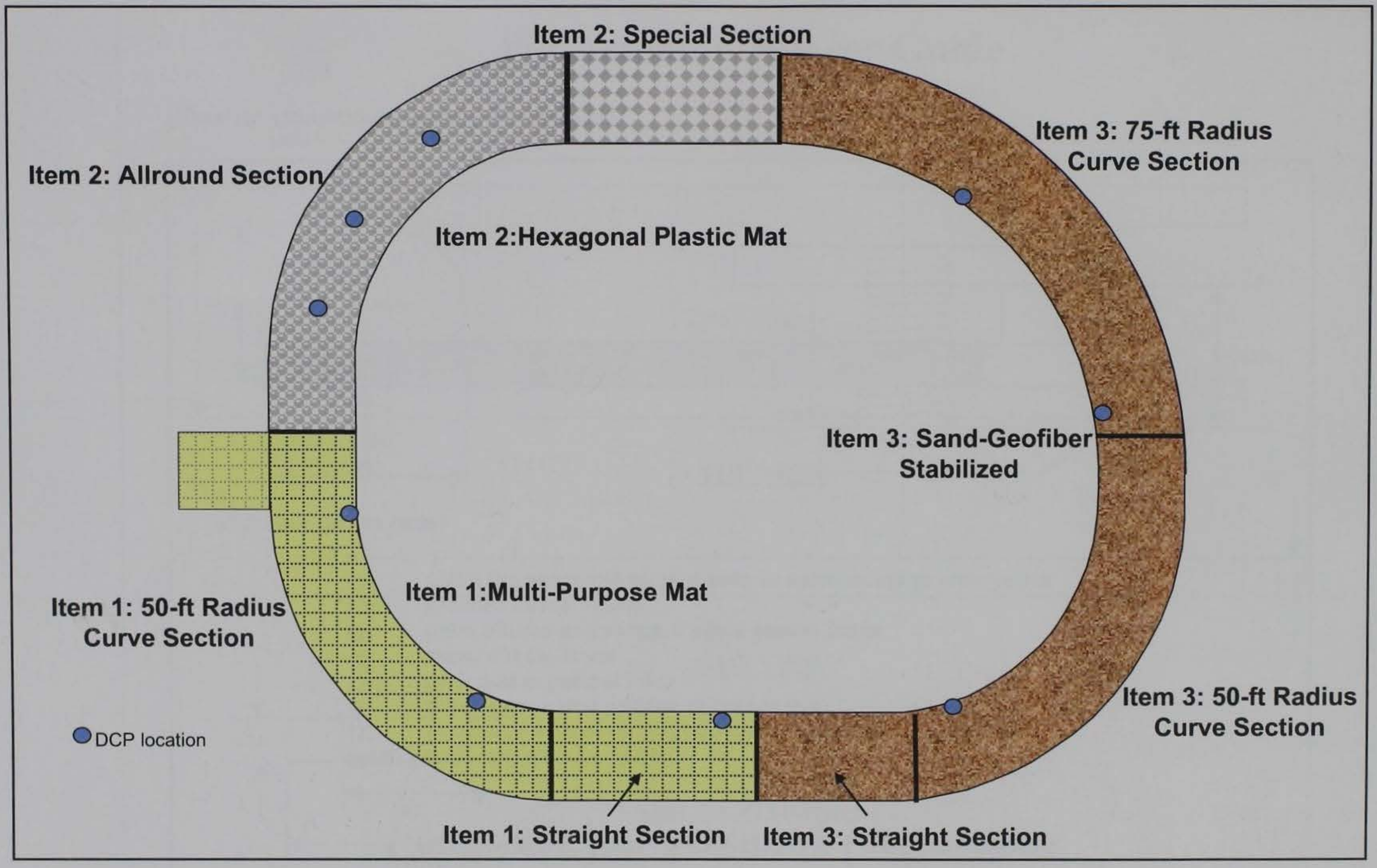

Figure 15. Item's sections layout 


\section{Connector Pin Assembly Instructions}

Note: To assemble connector pin

(1) Assemble washer on bolt and insert bolt thru top plate

(2) Dip bottom 4 bolt threads in Loctite 242

(3) Start bolt in bottom plate

(4) Insert spacer guide

(5) Hand tighten bolt to .25-in.-thick spacer guide

(6) Remove spacer guide

(7) Stand pin assembly on bolt head to allow loctite to cure $24 \mathrm{hrs}$.

0.25 " thick Spacer Guide

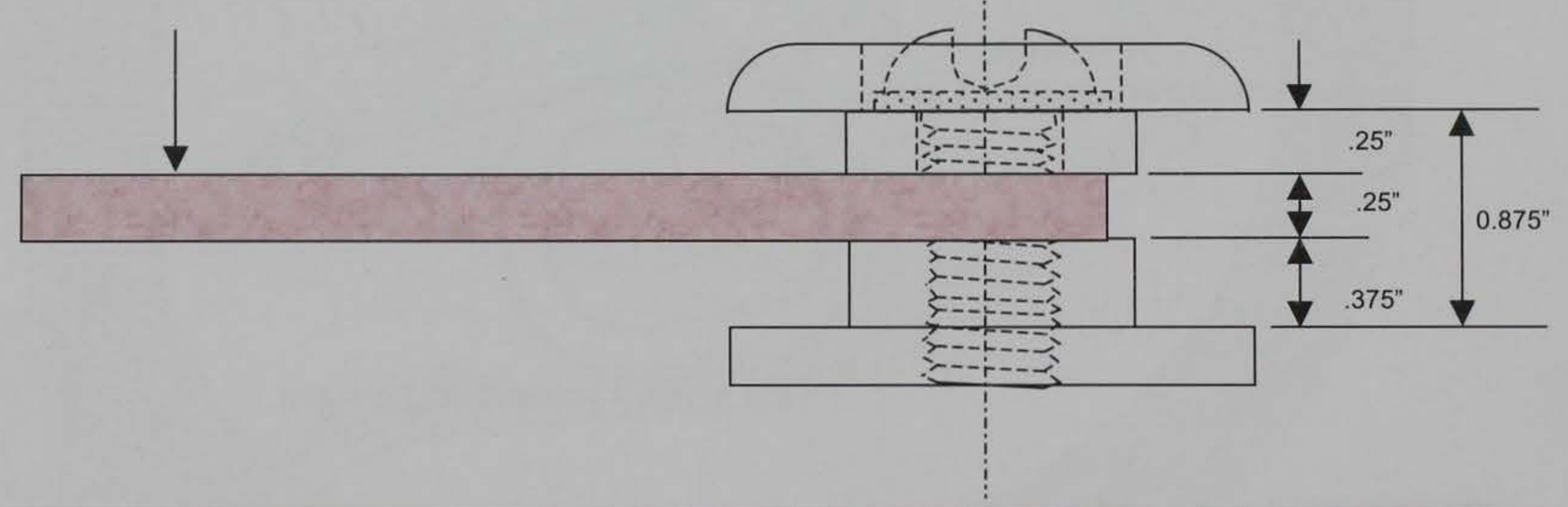

Figure 16. Connector pin assembly instructions 


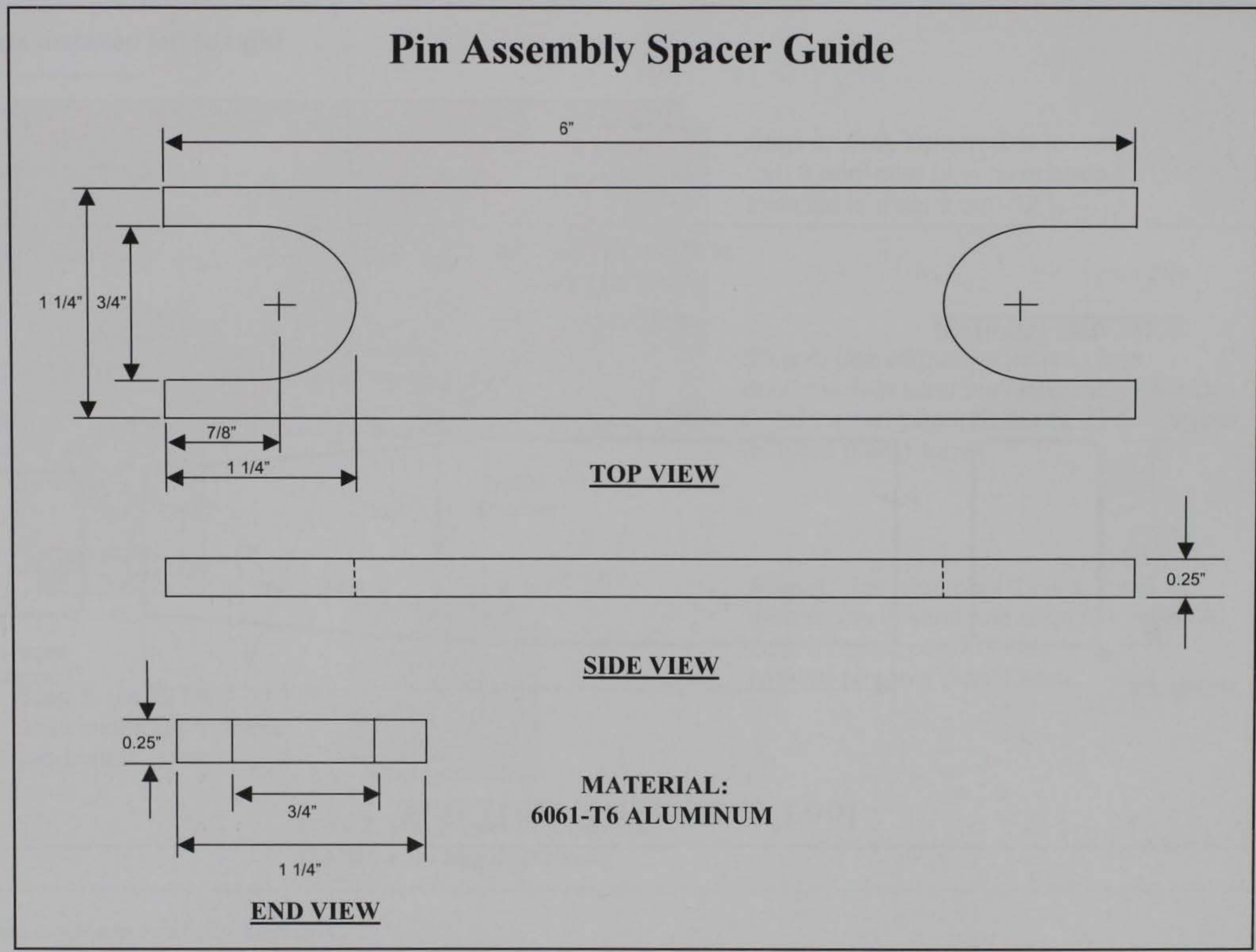

Figure 17. Spacer guide dimensions 


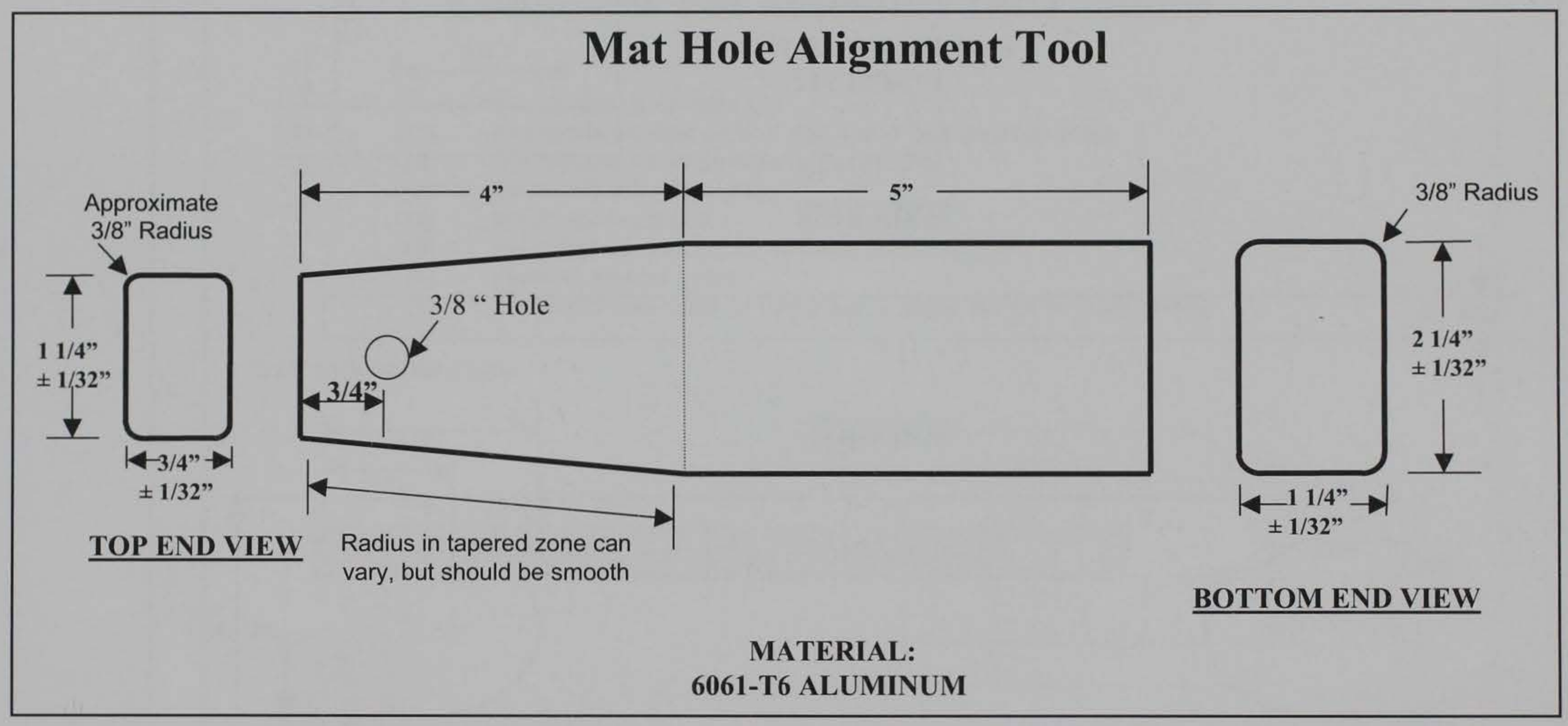

Figure 18. Alignment tool dimensions 


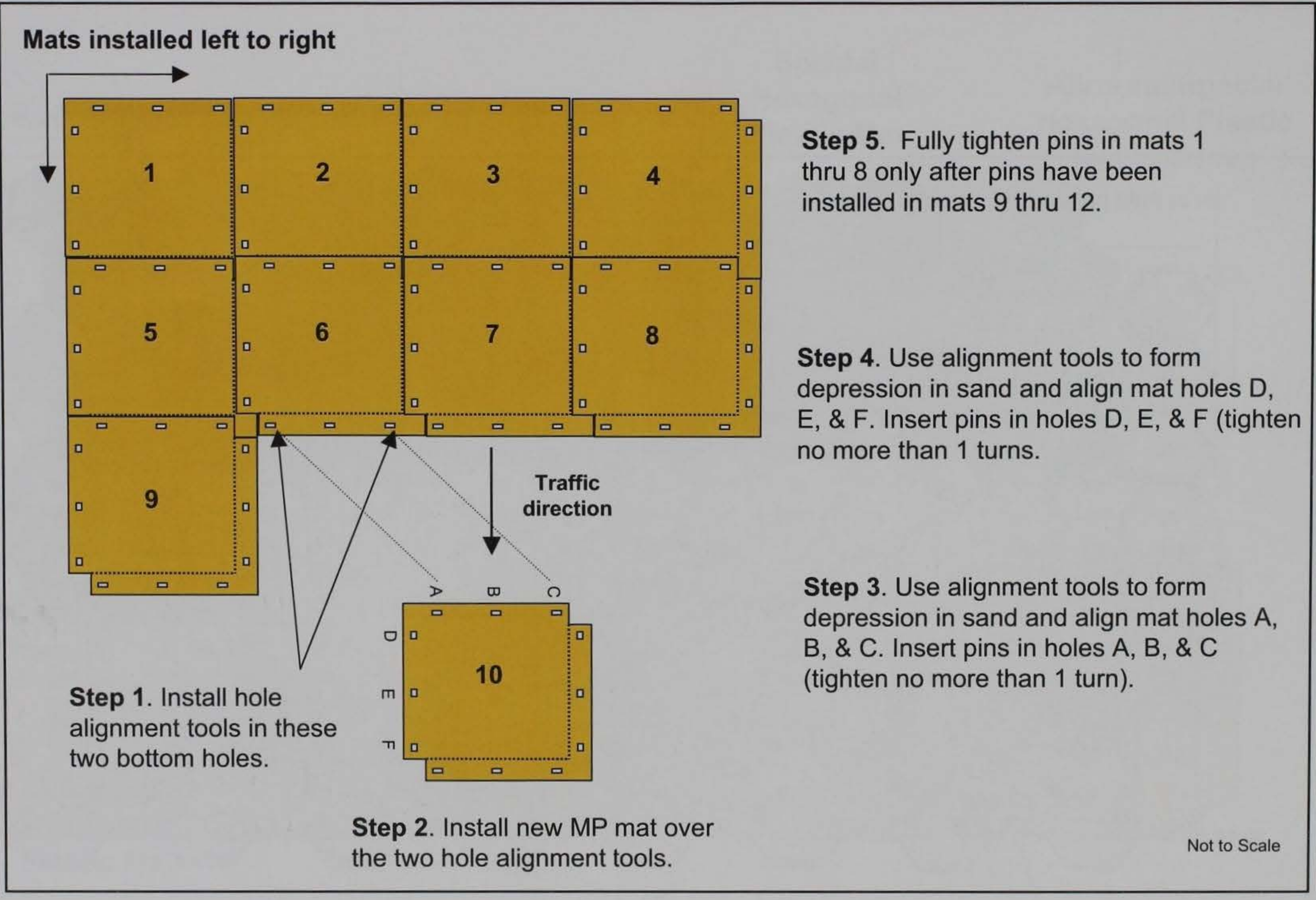

Figure 19. MP mat installation procedure 


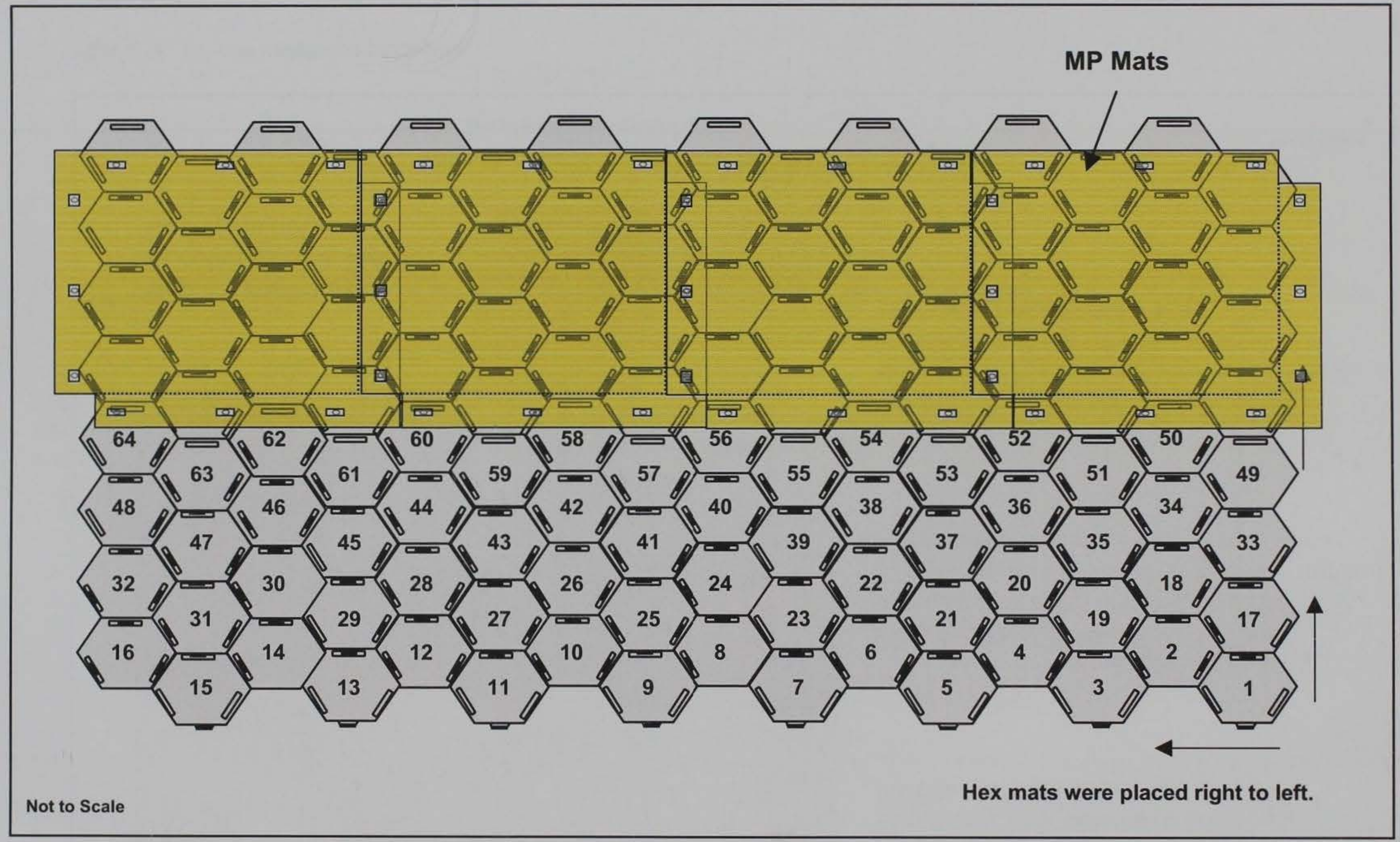

Figure 20. Placement pattern for Allround hexagonal plastic mat 


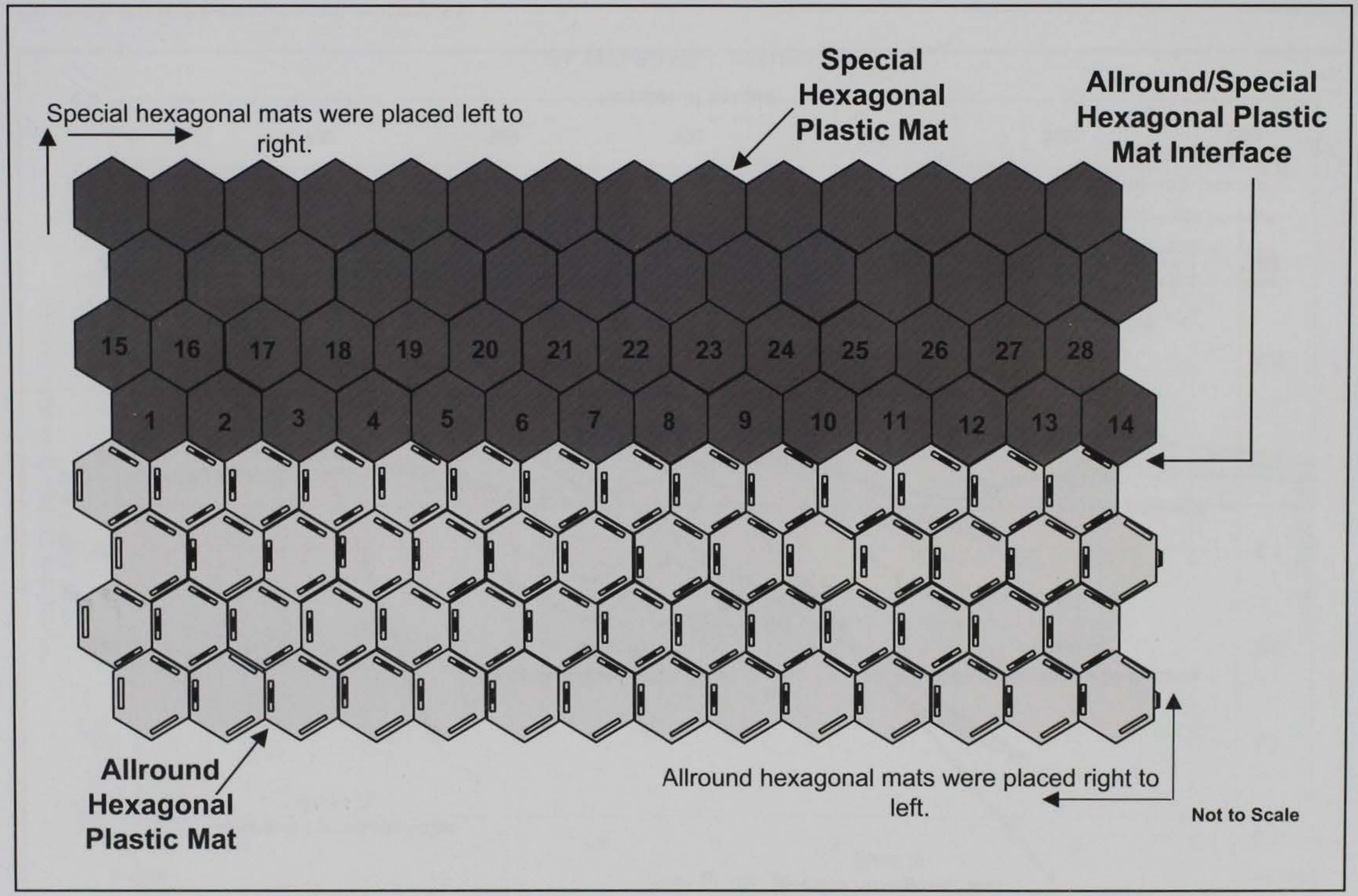

Figure 21. Placement pattern for Special hexagonal plastic mat and transition zone between mats 


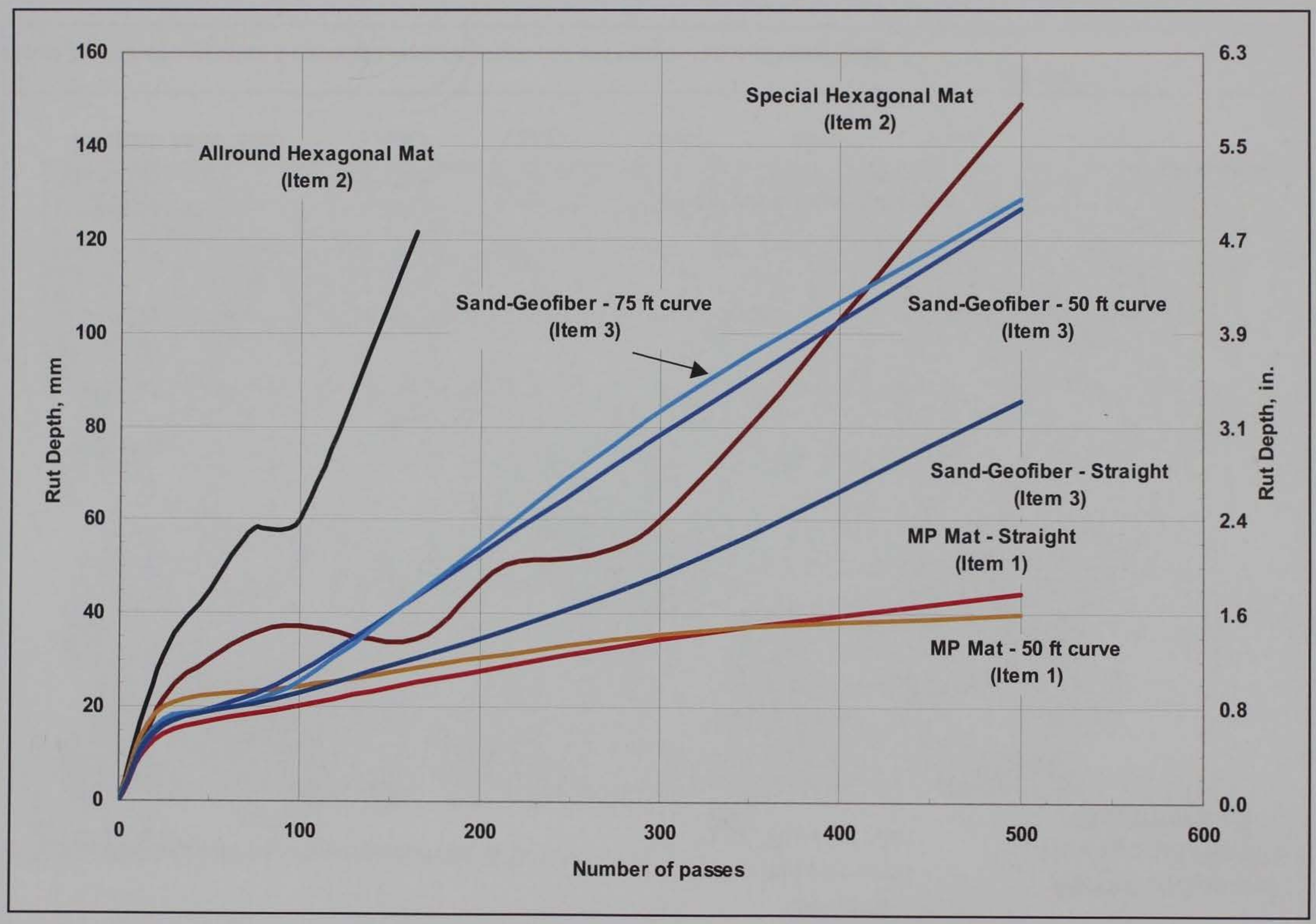

Figure 22. Rut depth measurement for Items 1 to 3 


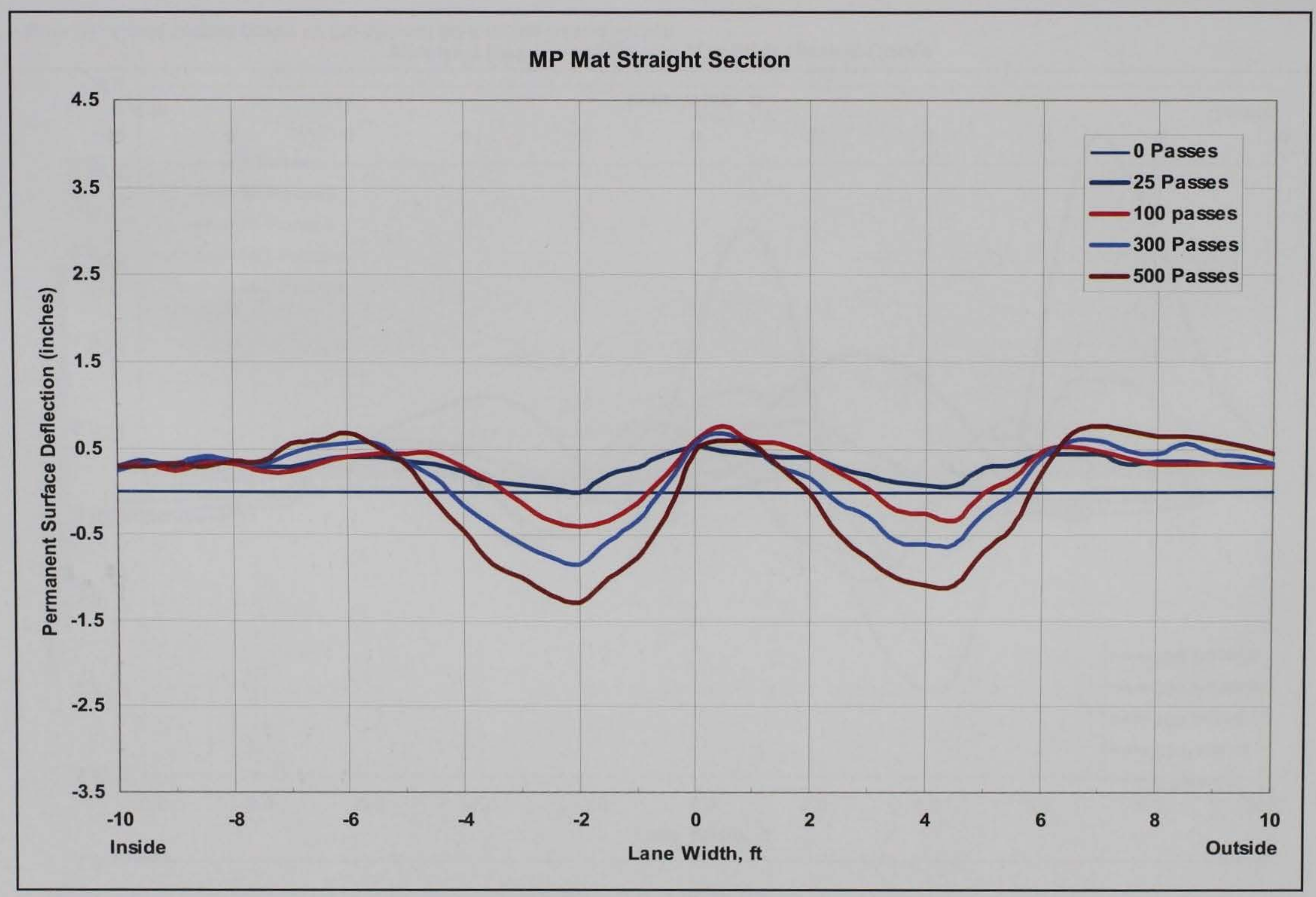

Figure 23. Cross section profile for the MP mat straight section 


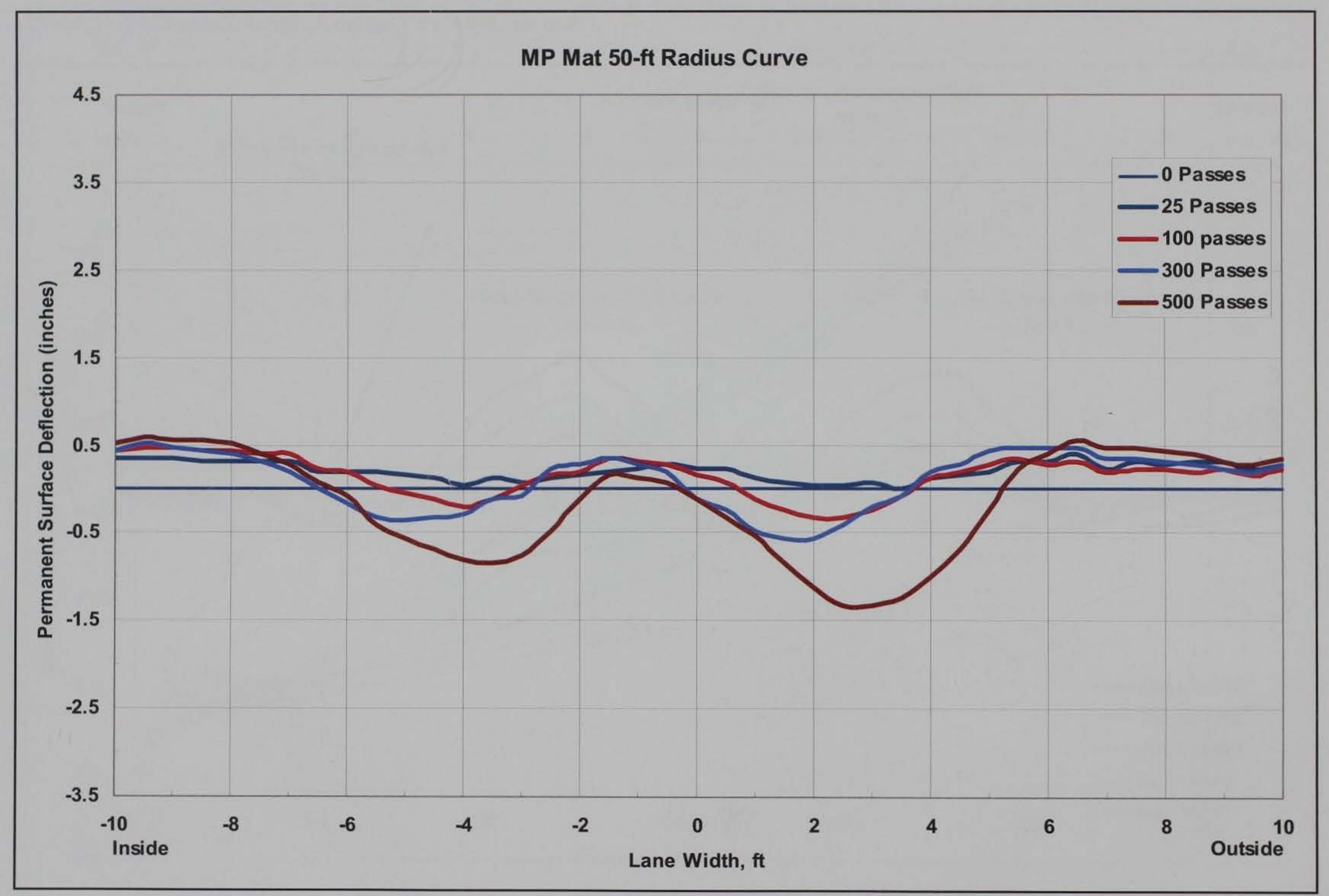

Figure 24. Cross section profile for the MP mat 50-ft radius curved section 


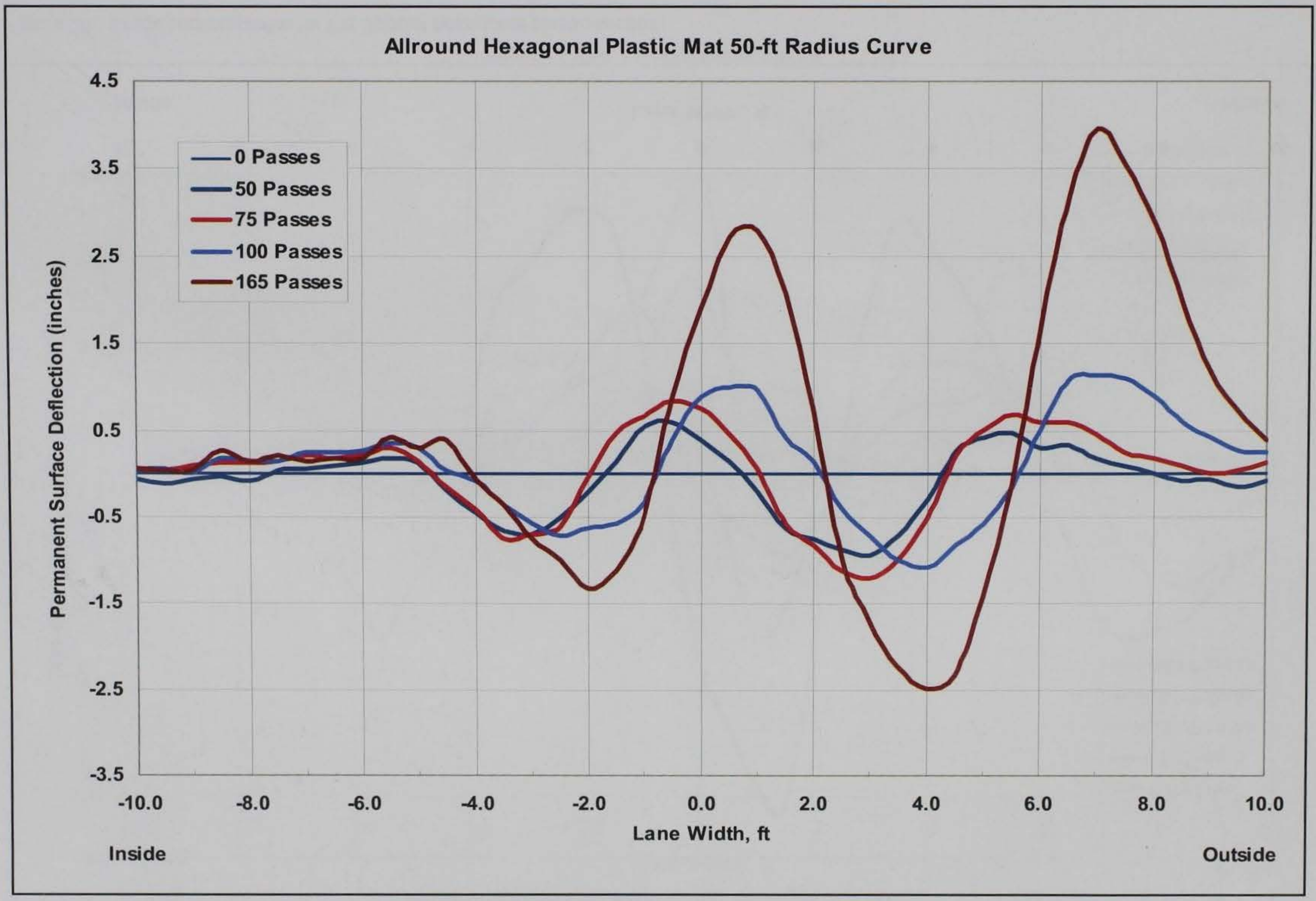

Figure 25. Cross section profile for the Allround hexagonal plastic section 


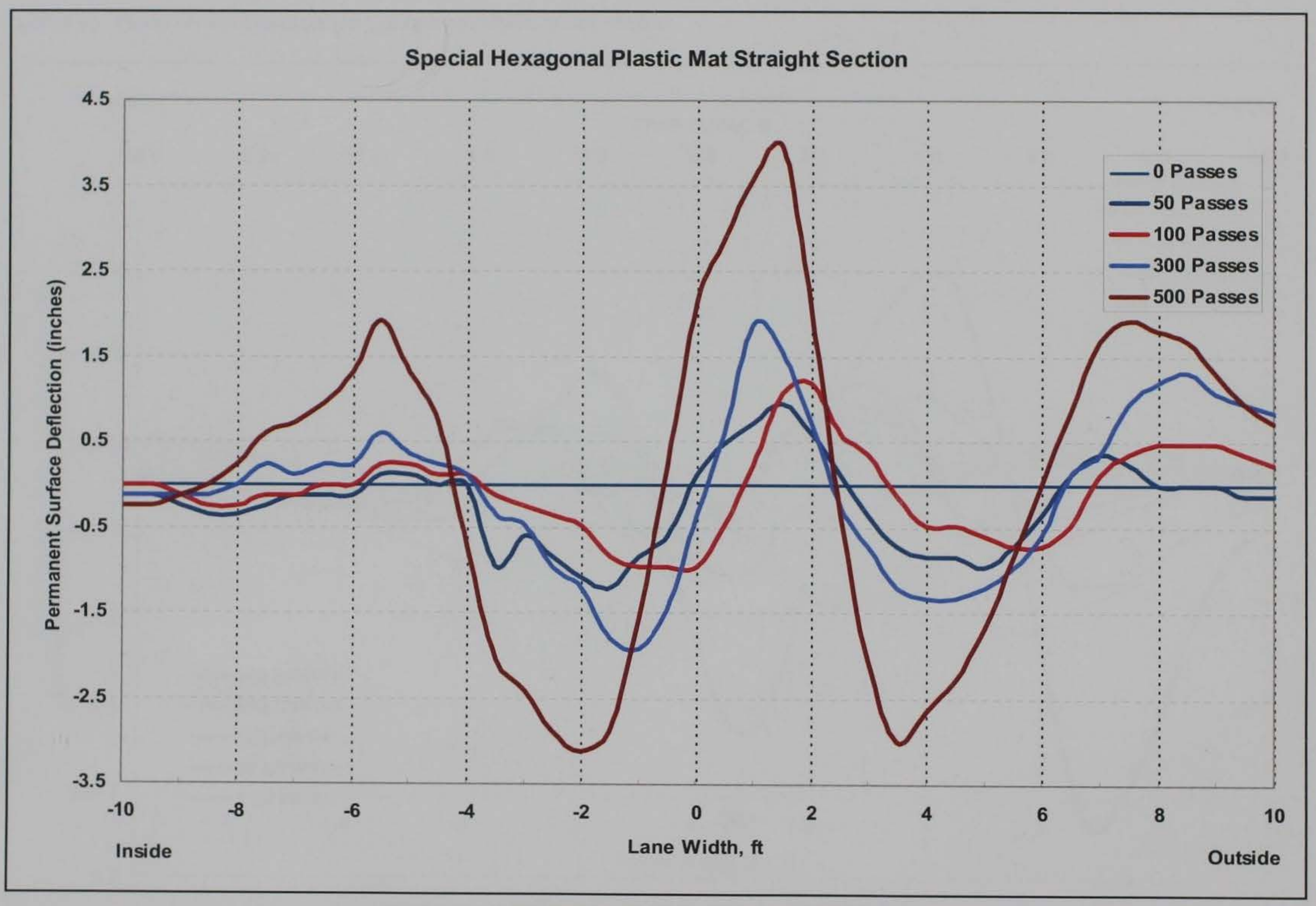

Figure 26. Cross section profile for the Special hexagonal plastic section 


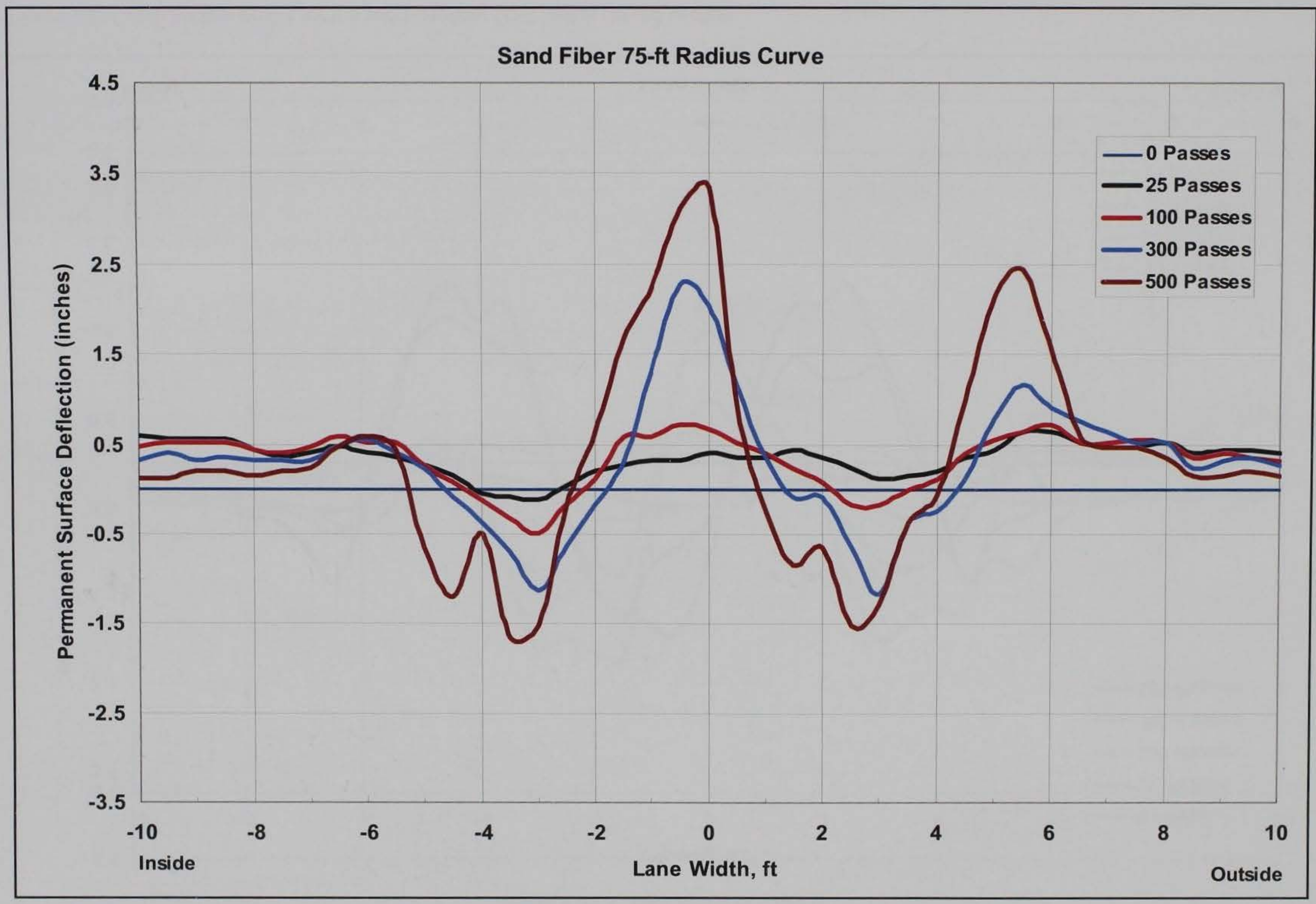

Figure 27. Cross section profile for the sand-geofiber 75 -ft radius curved section 


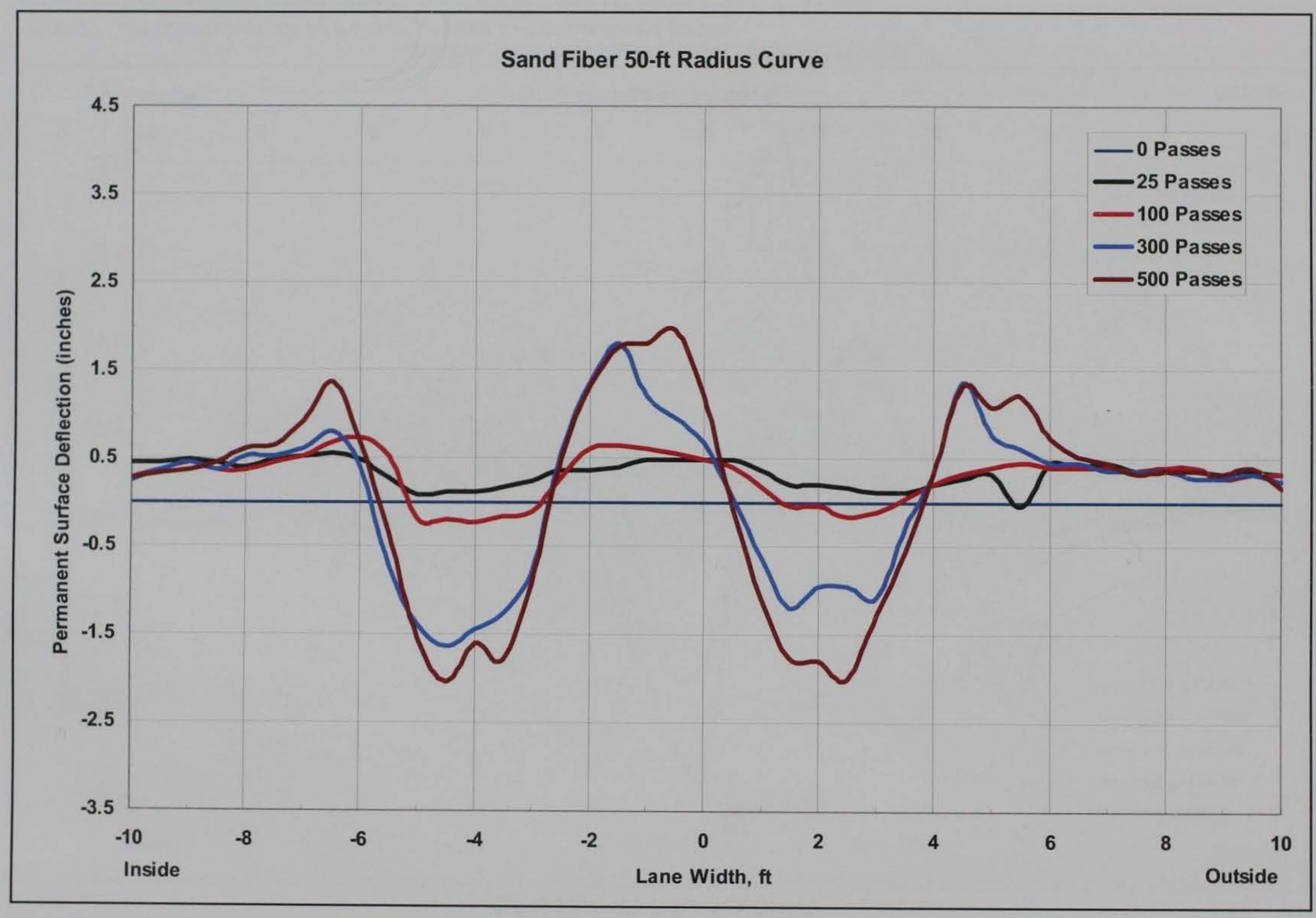

Figure 28. Cross section profile for the sand-geofiber 50 -ft radius curved section 


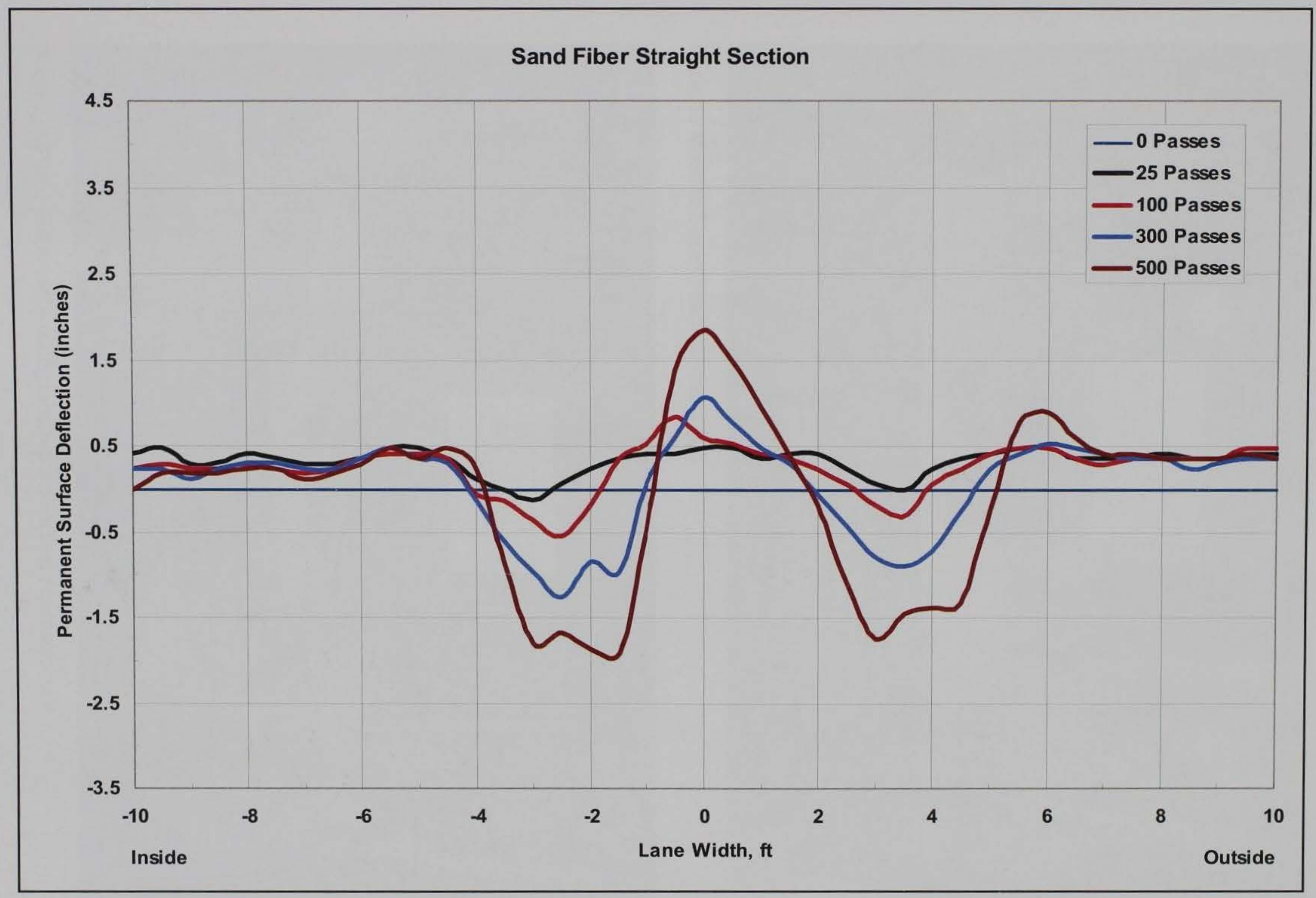

Figure 29. Cross section profile for the sand-geofiber straight section 


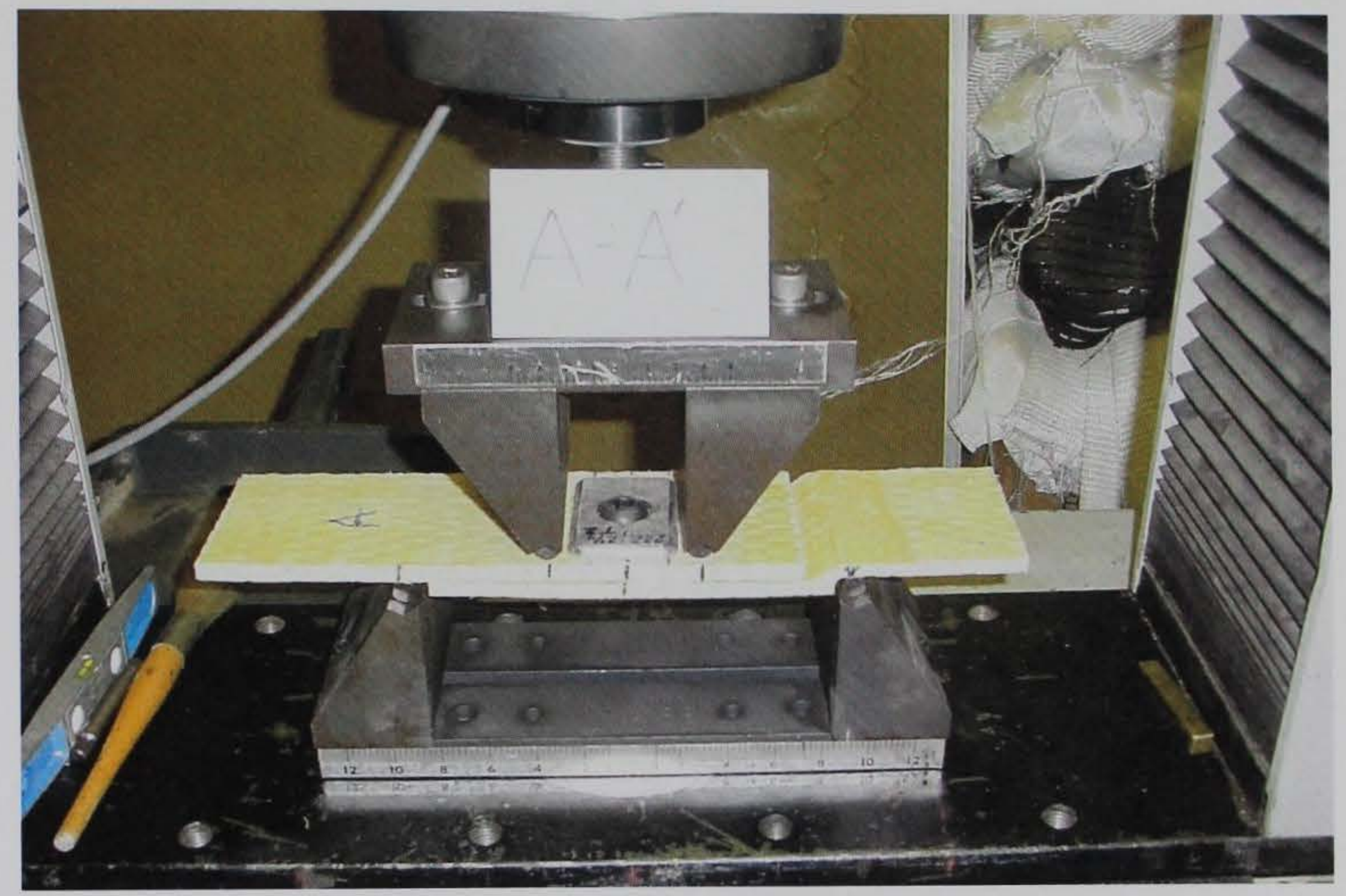

Photo 1. Modified 3-point beam connector test

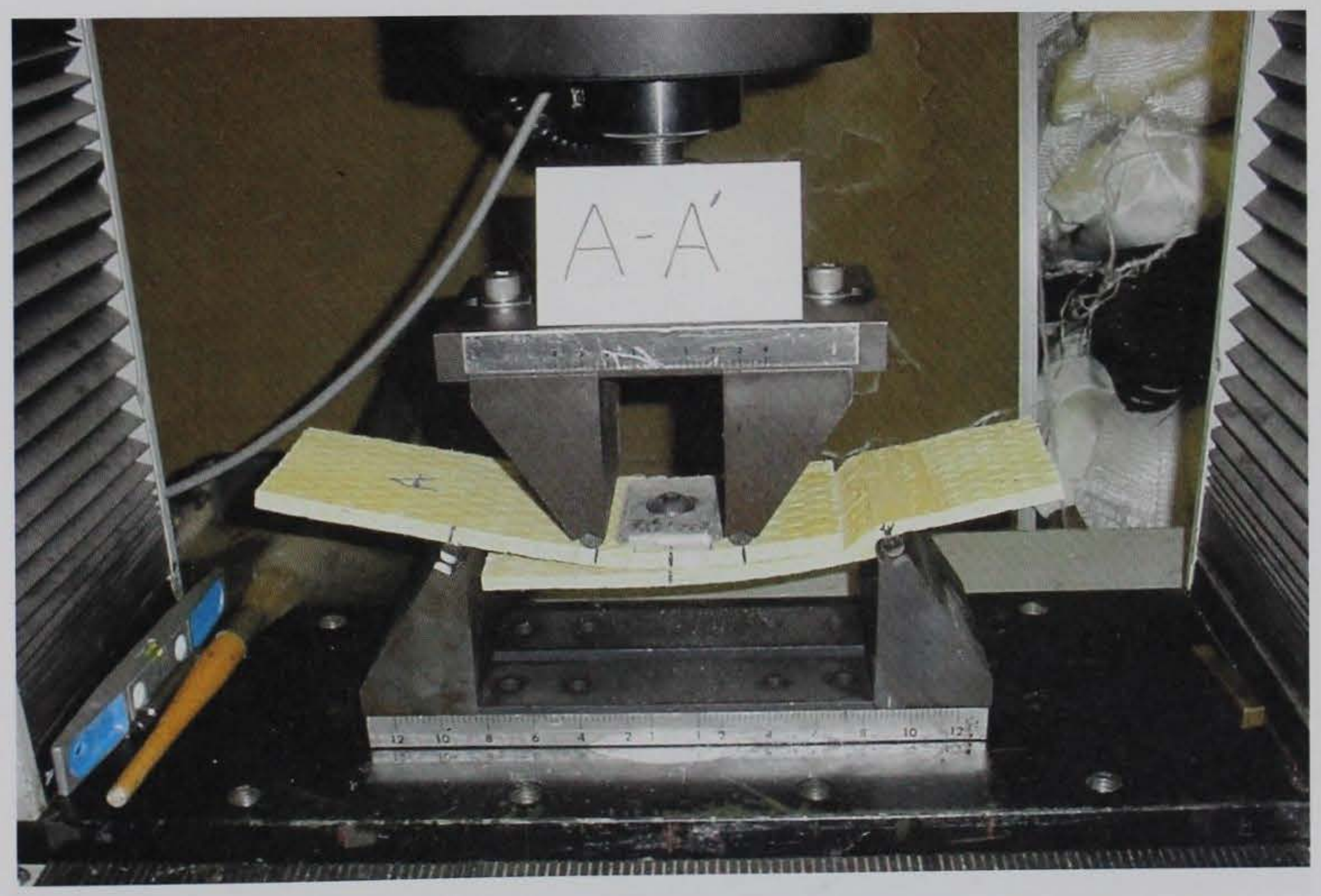

Photo 2. MP mat performance during modified 3-point beam connector test 


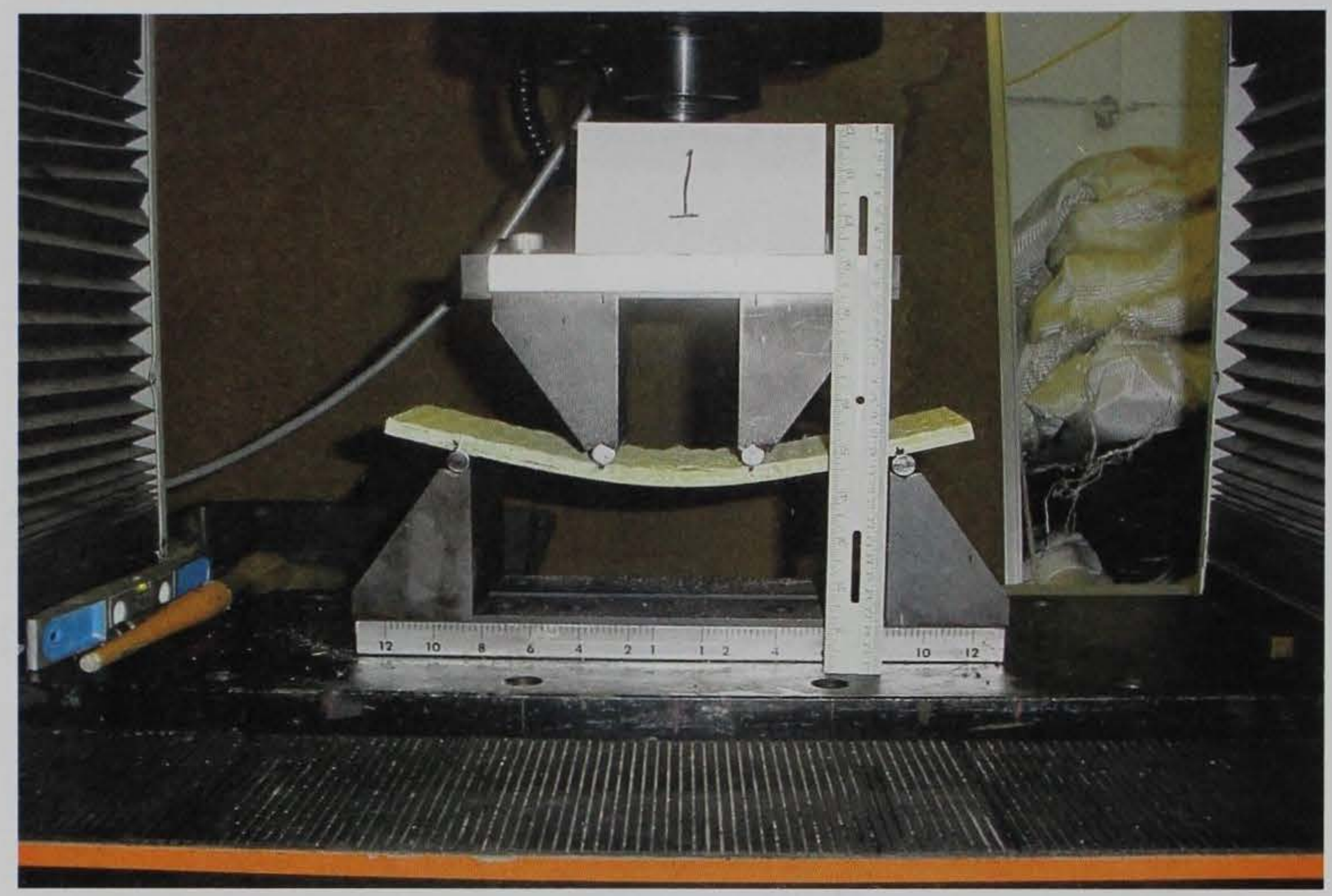

Photo 3. Modified 3-point beam test

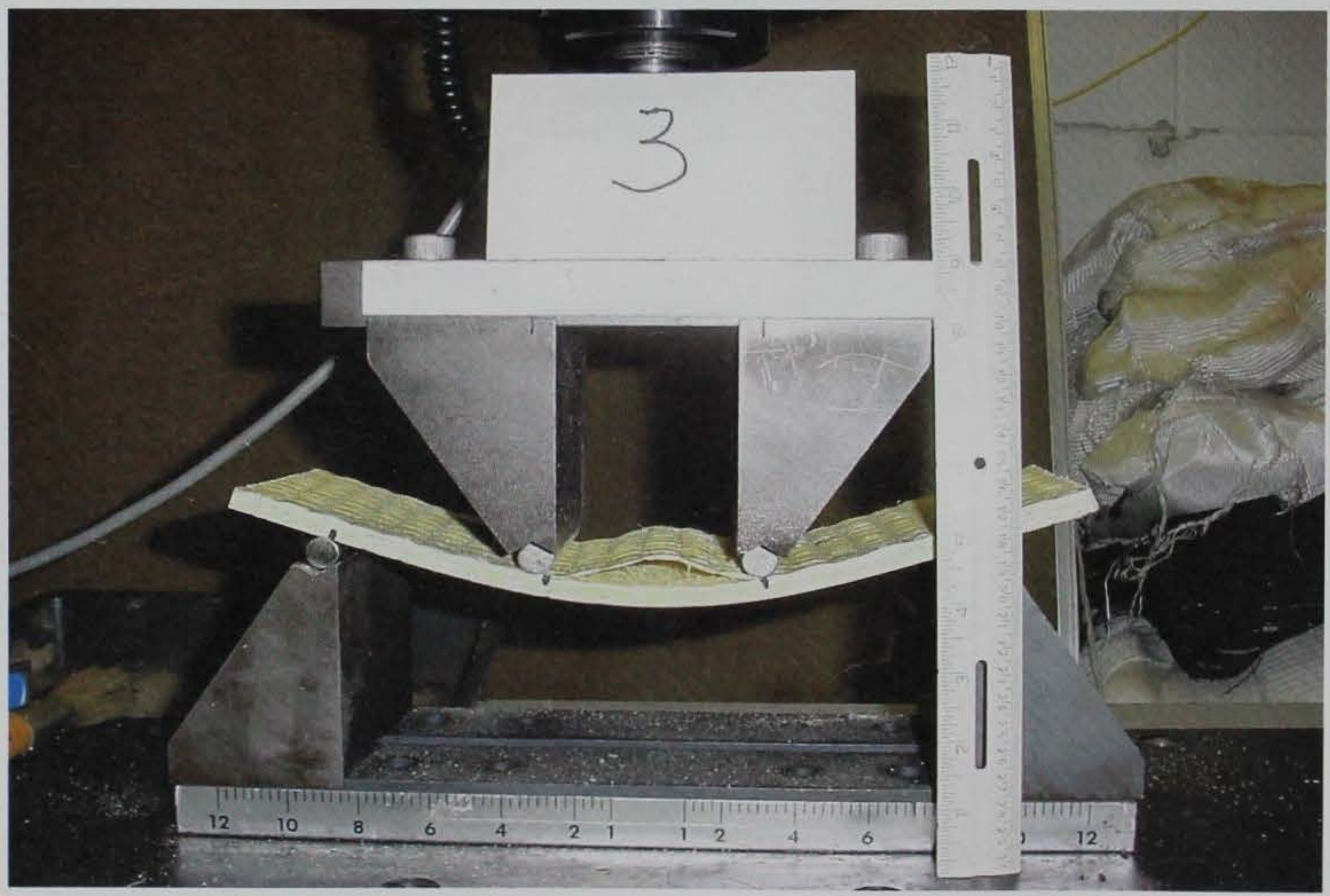

Photo 4. MP mat performance modified 3-point beam test 


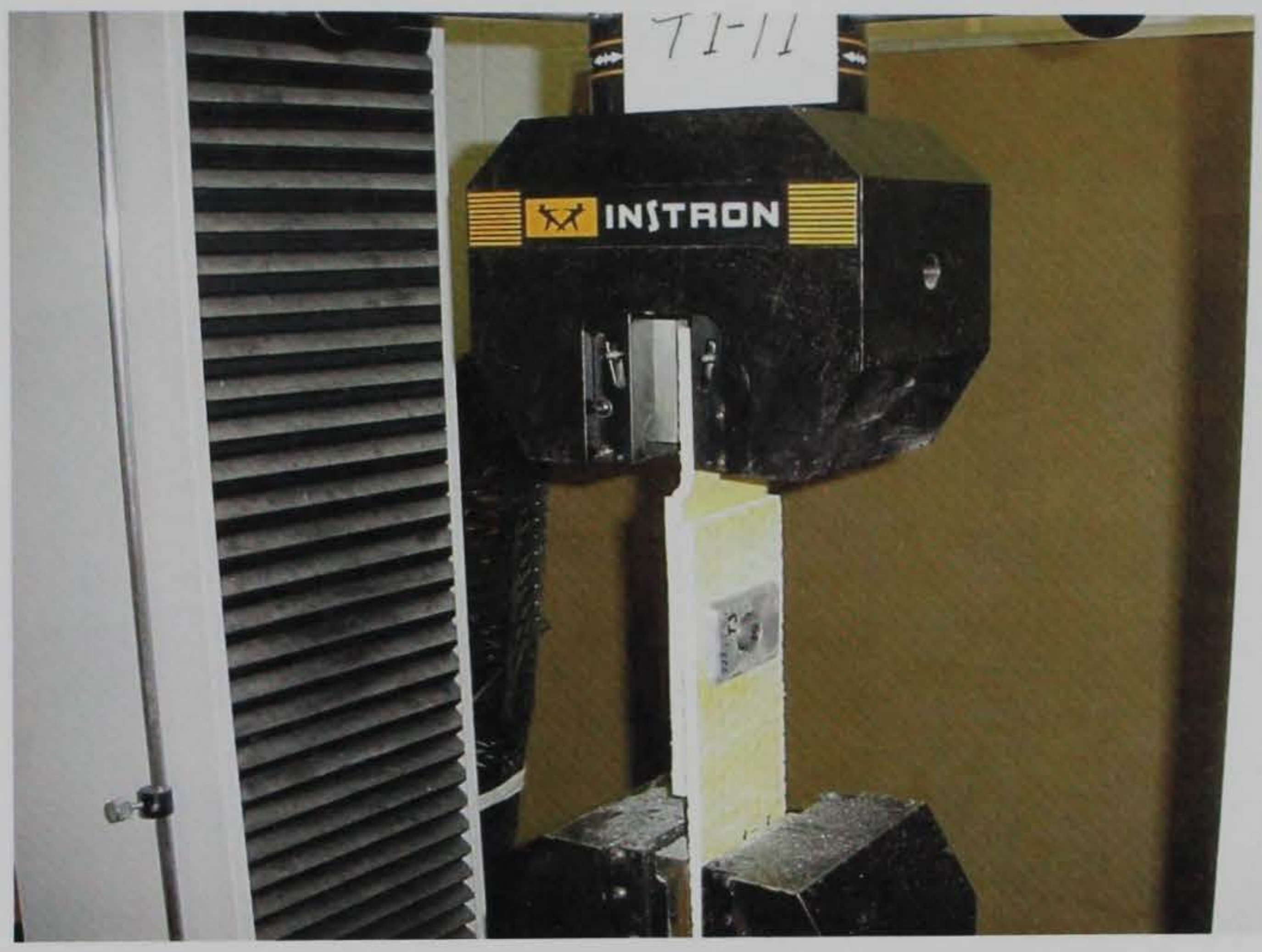

Photo 5. Modified direct connector tension test

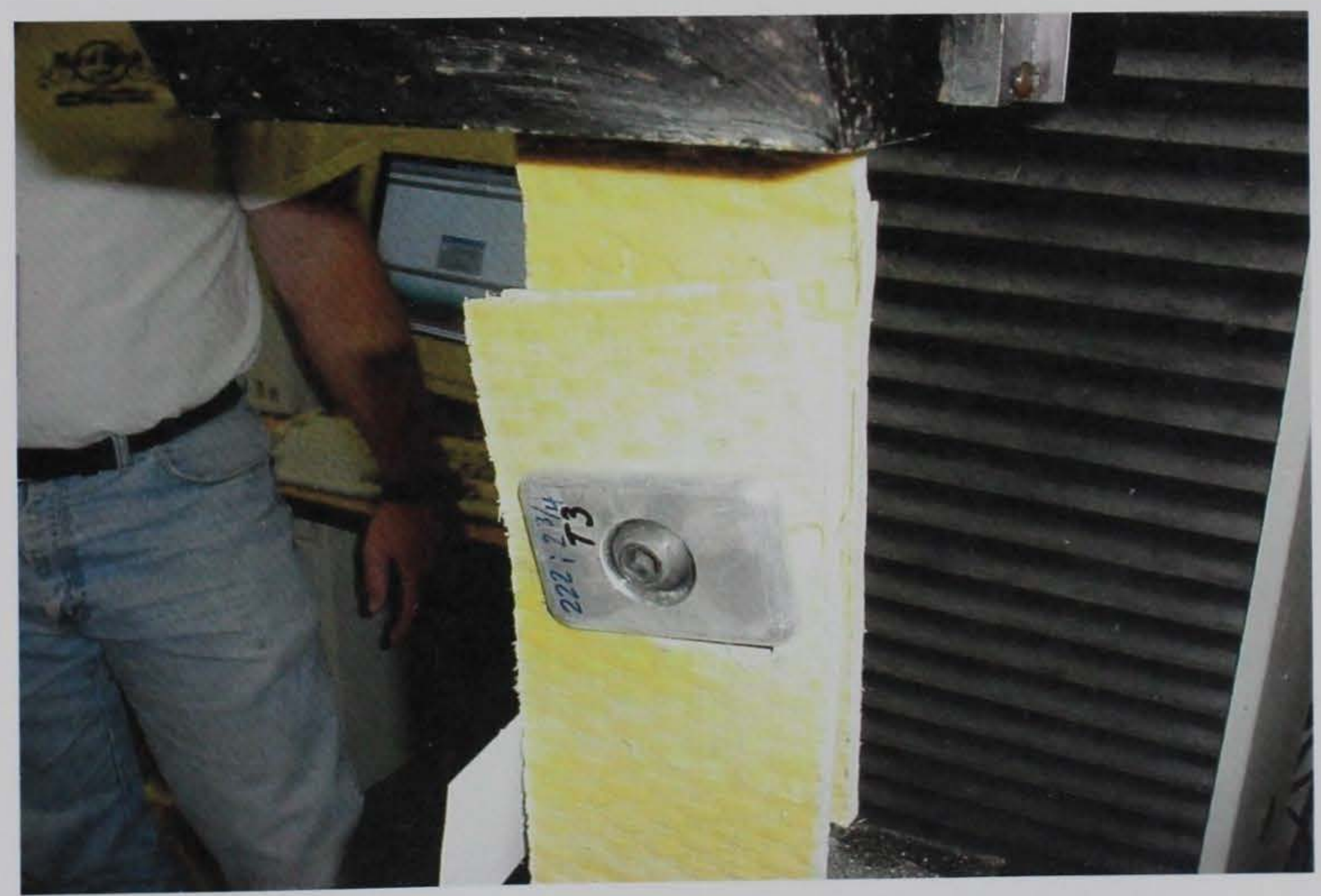

Photo 6. MP mat performance during modified direct tension test 


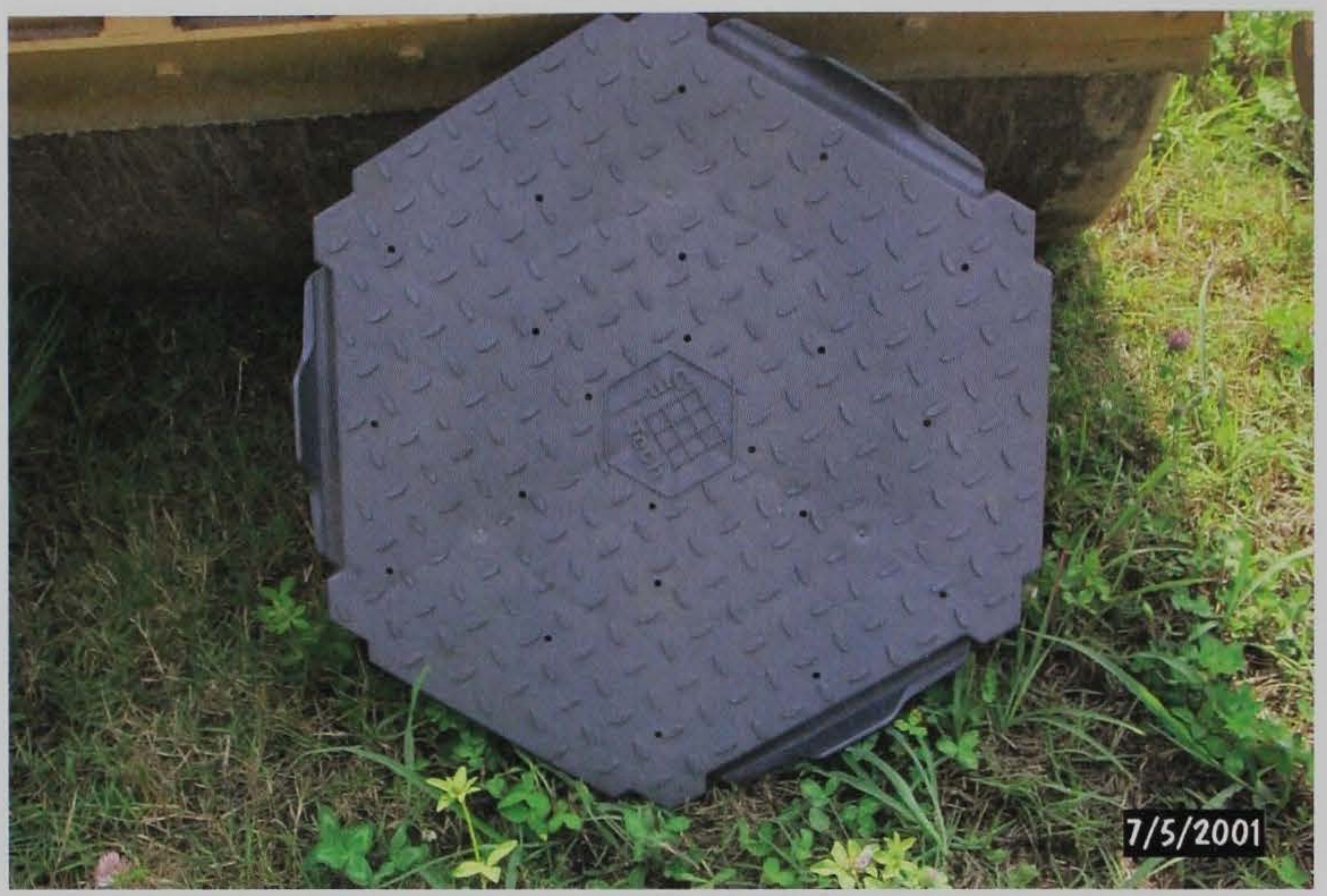

Photo 7. Hexagonal plastic mat - Special top view

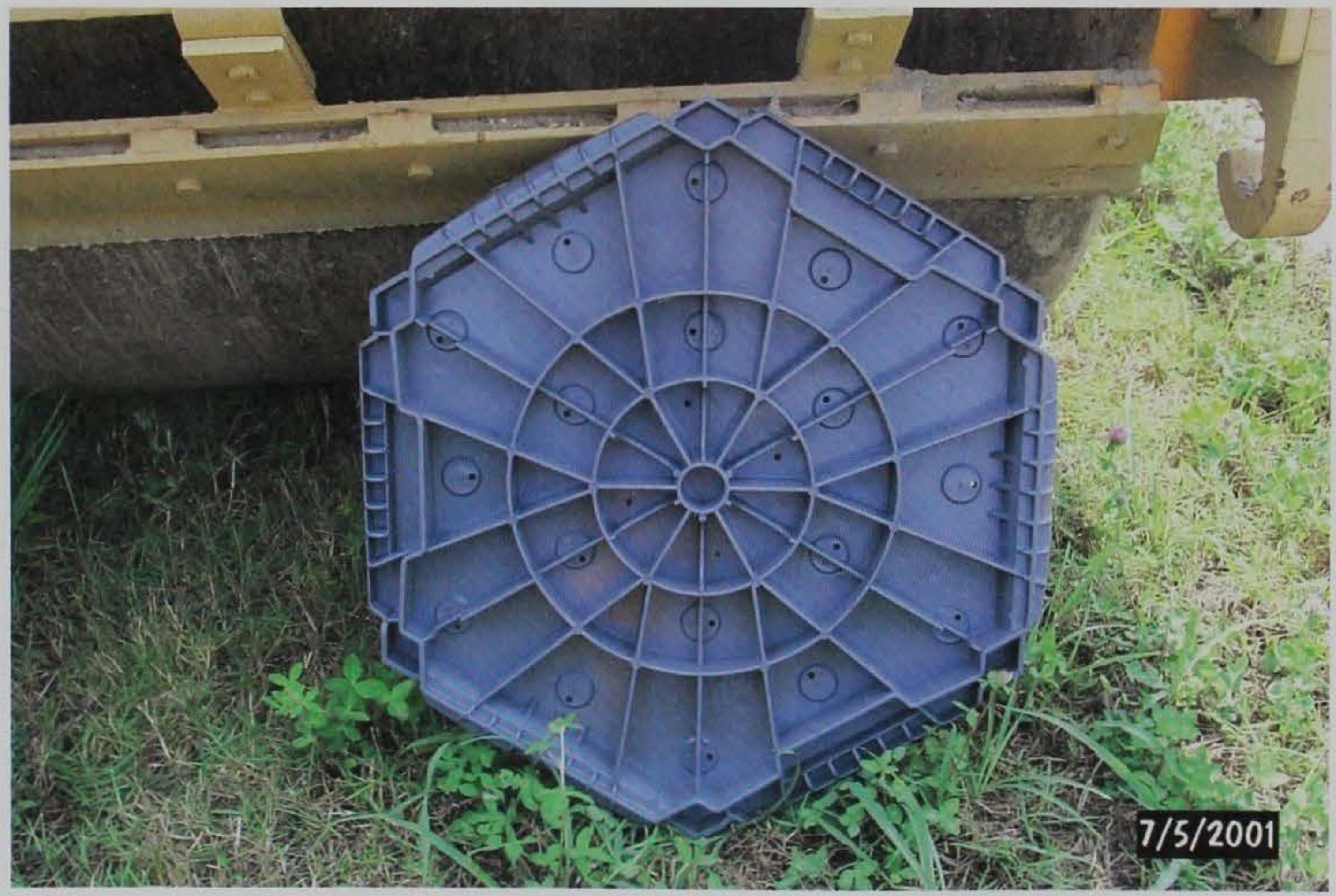

Photo 8. Hexagonal plastic mat - Special bottom view 


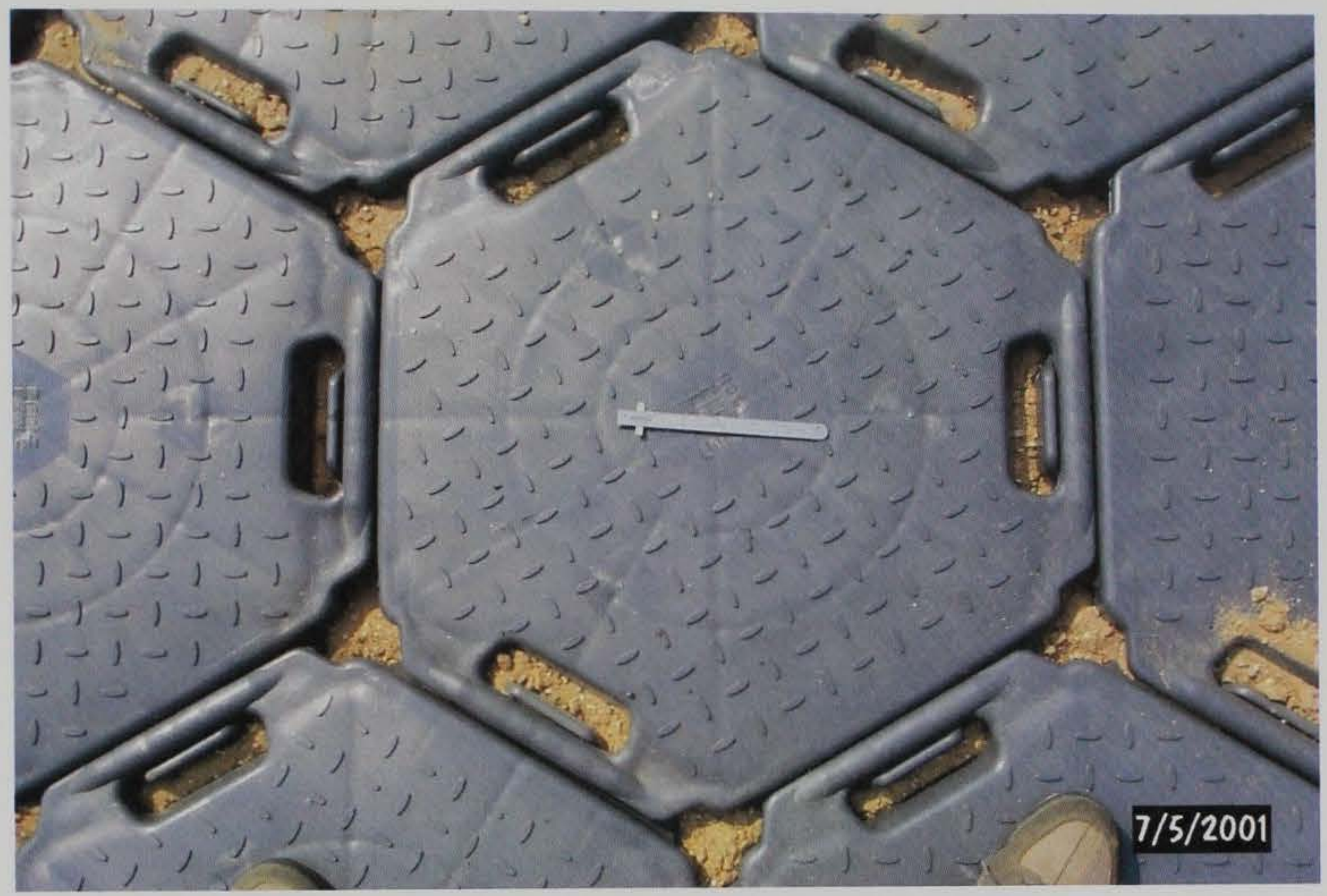

Photo 9. Hexagonal plastic mat - Allround top view

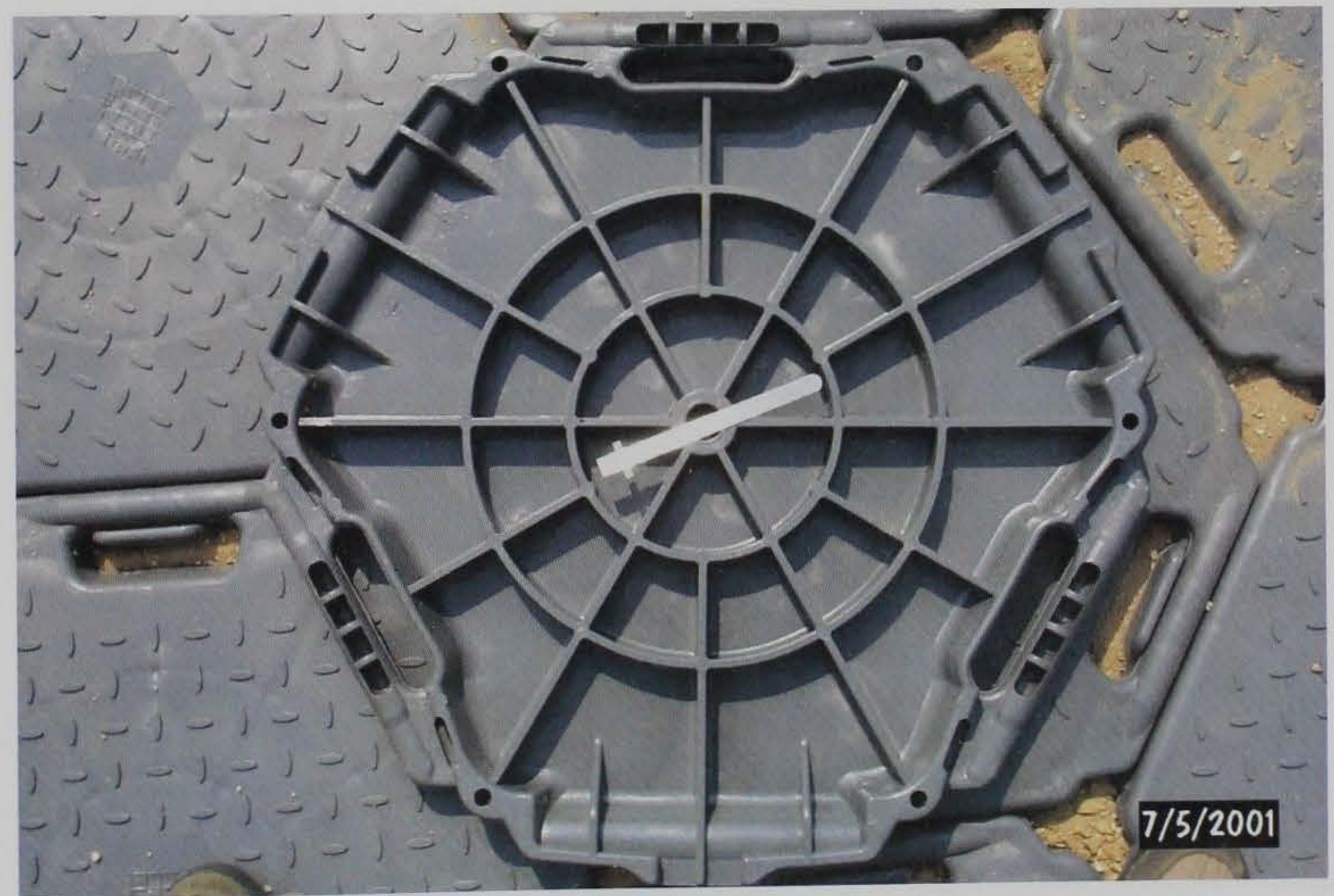

Photo 10. Hexagonal plastic mat - Allround bottom view 


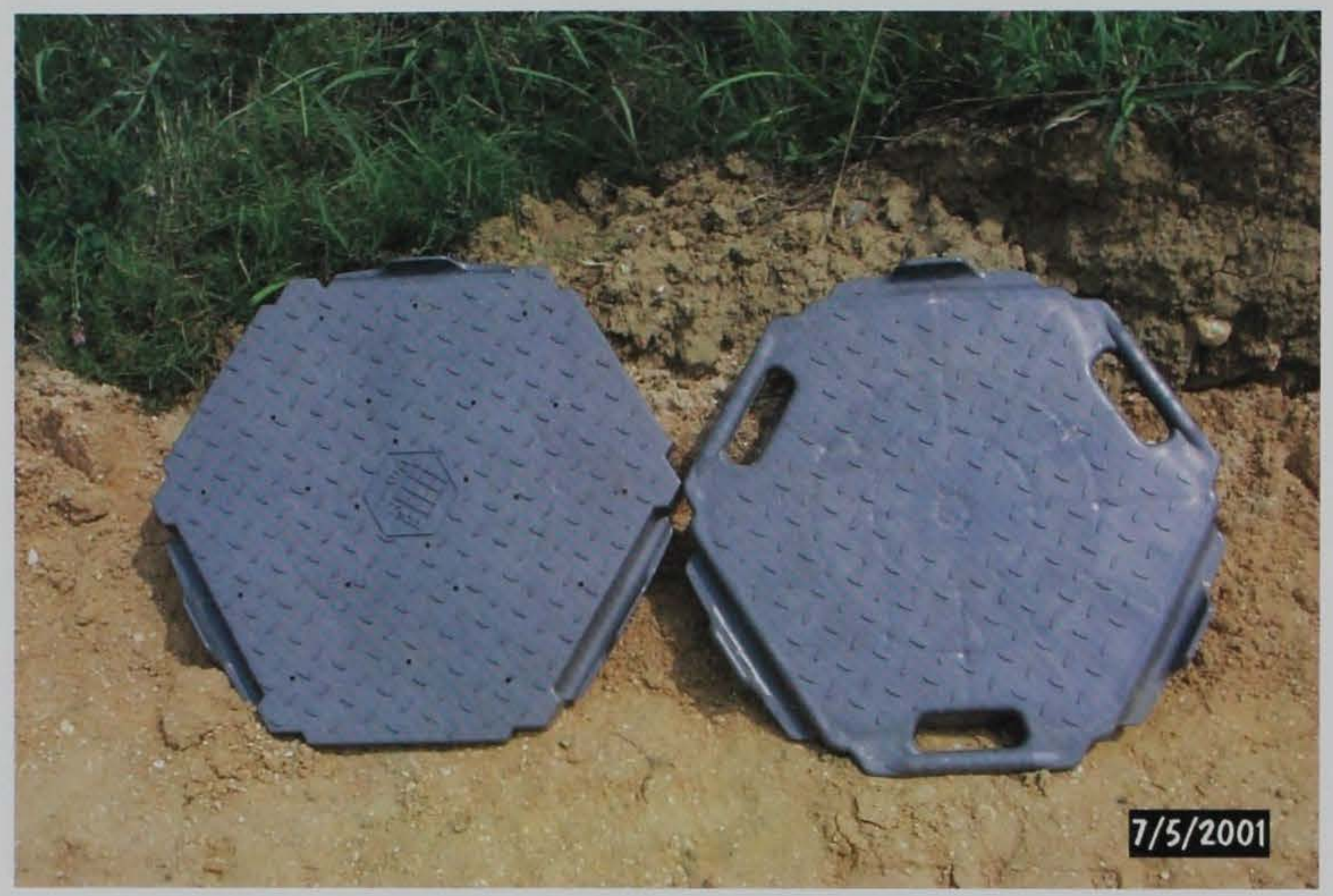

Photo 11. Hexagonal plastic mat -Special (left) and Allround (right), top view

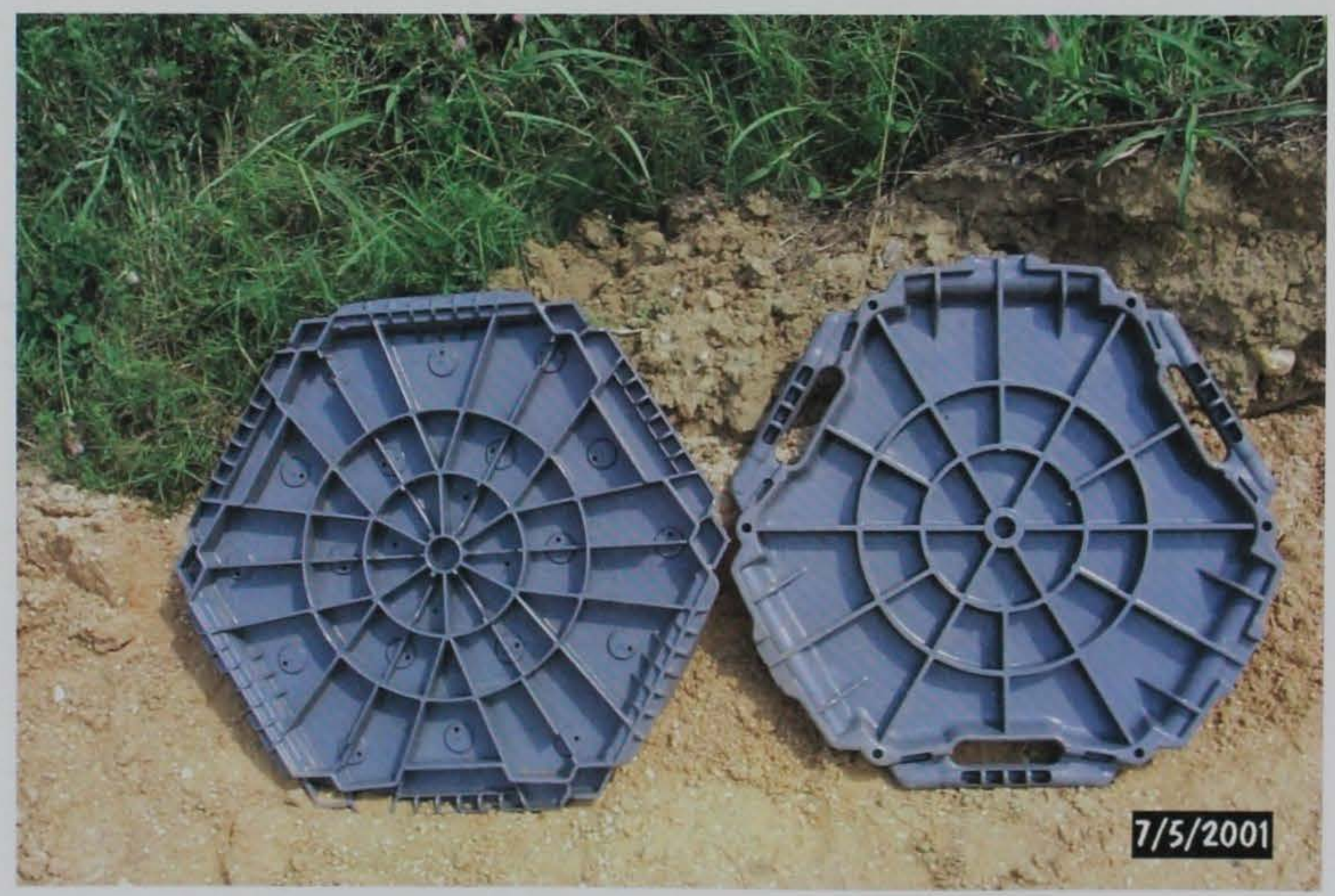

Photo 12. Hexagonal plastic mat - Special (left) and Allround (right), bottom view 


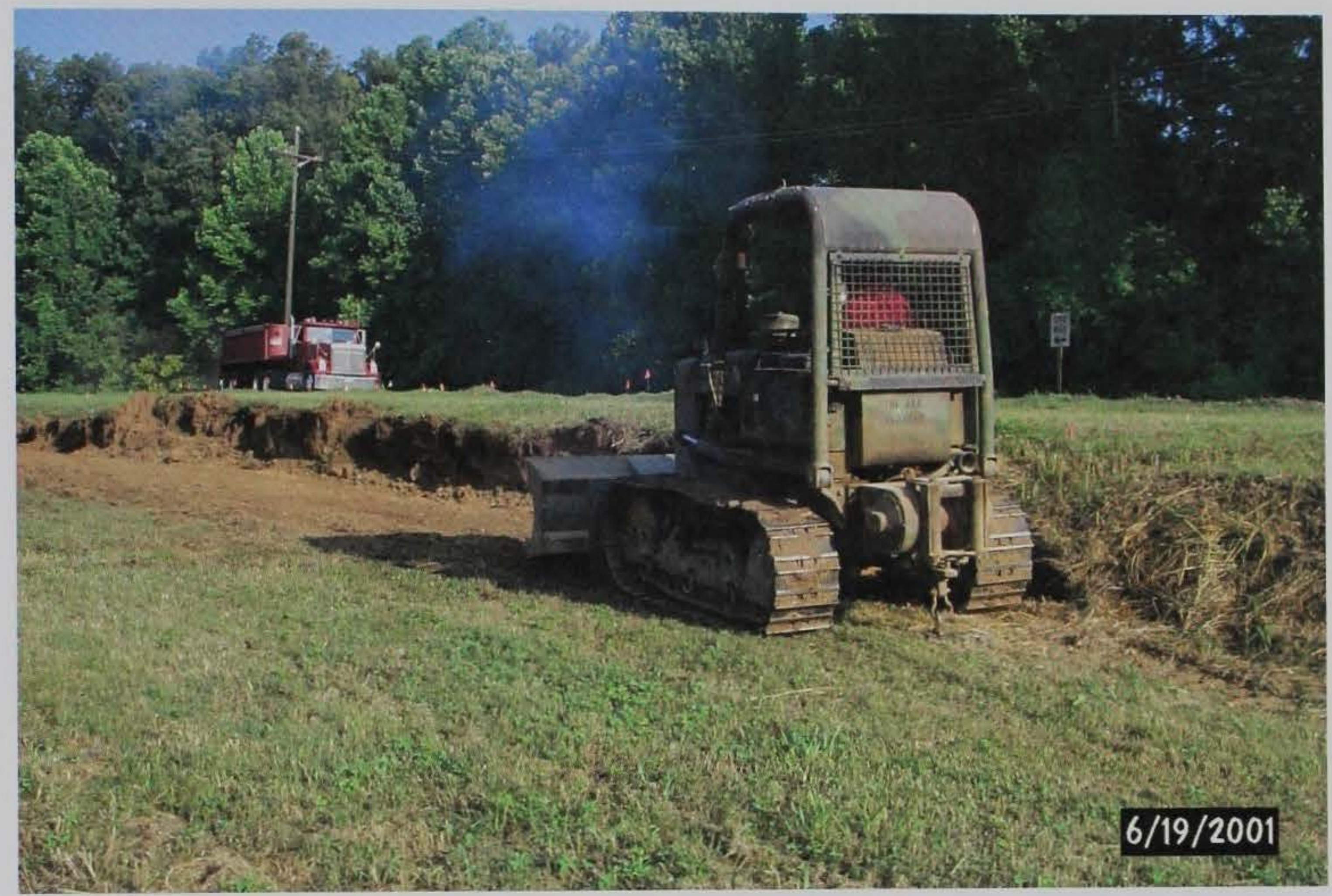

Photo 13. South edge cut at the Susquehana Circle gravel road

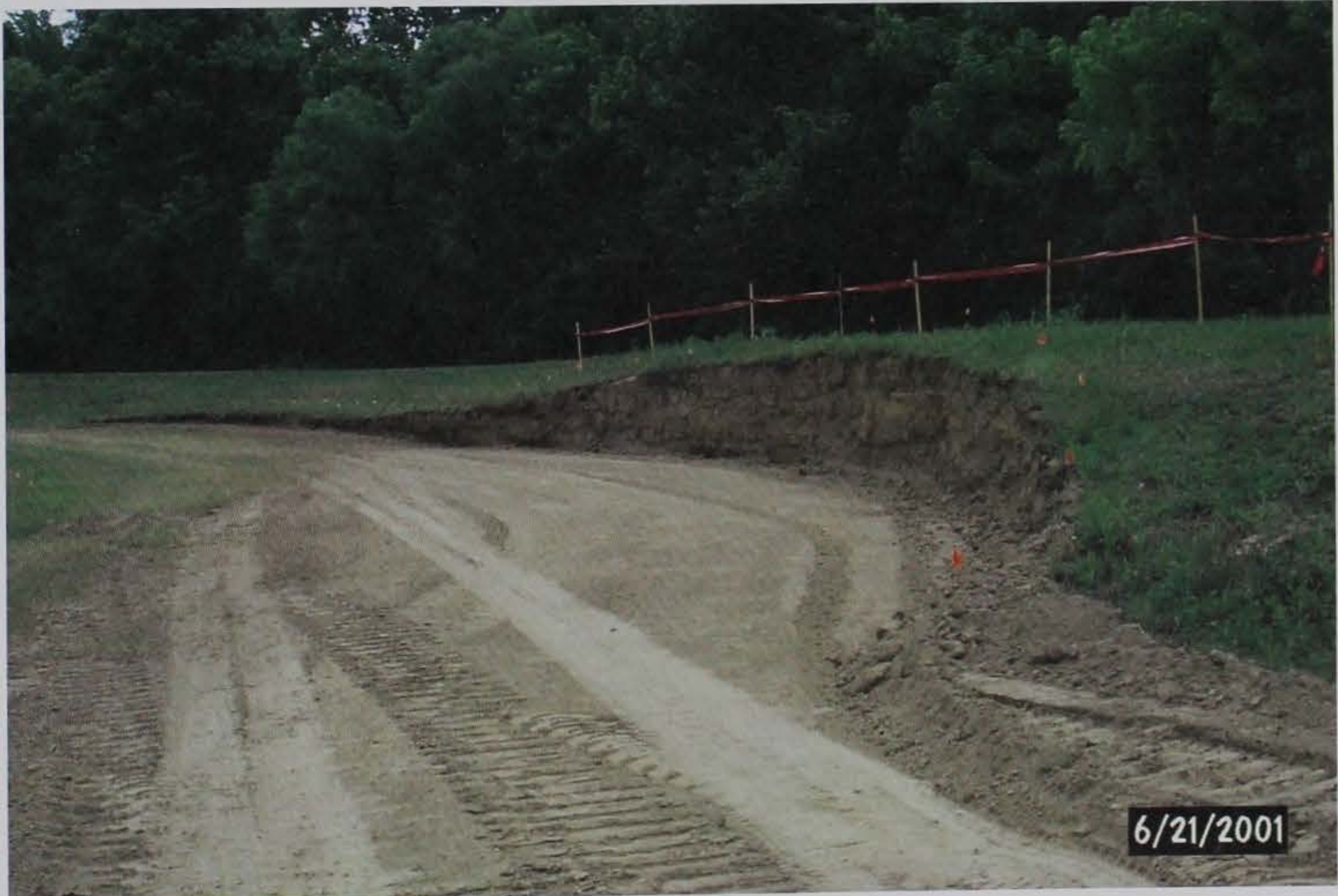

Photo 14. North edge cut at the Susquehana Circle gravel road 


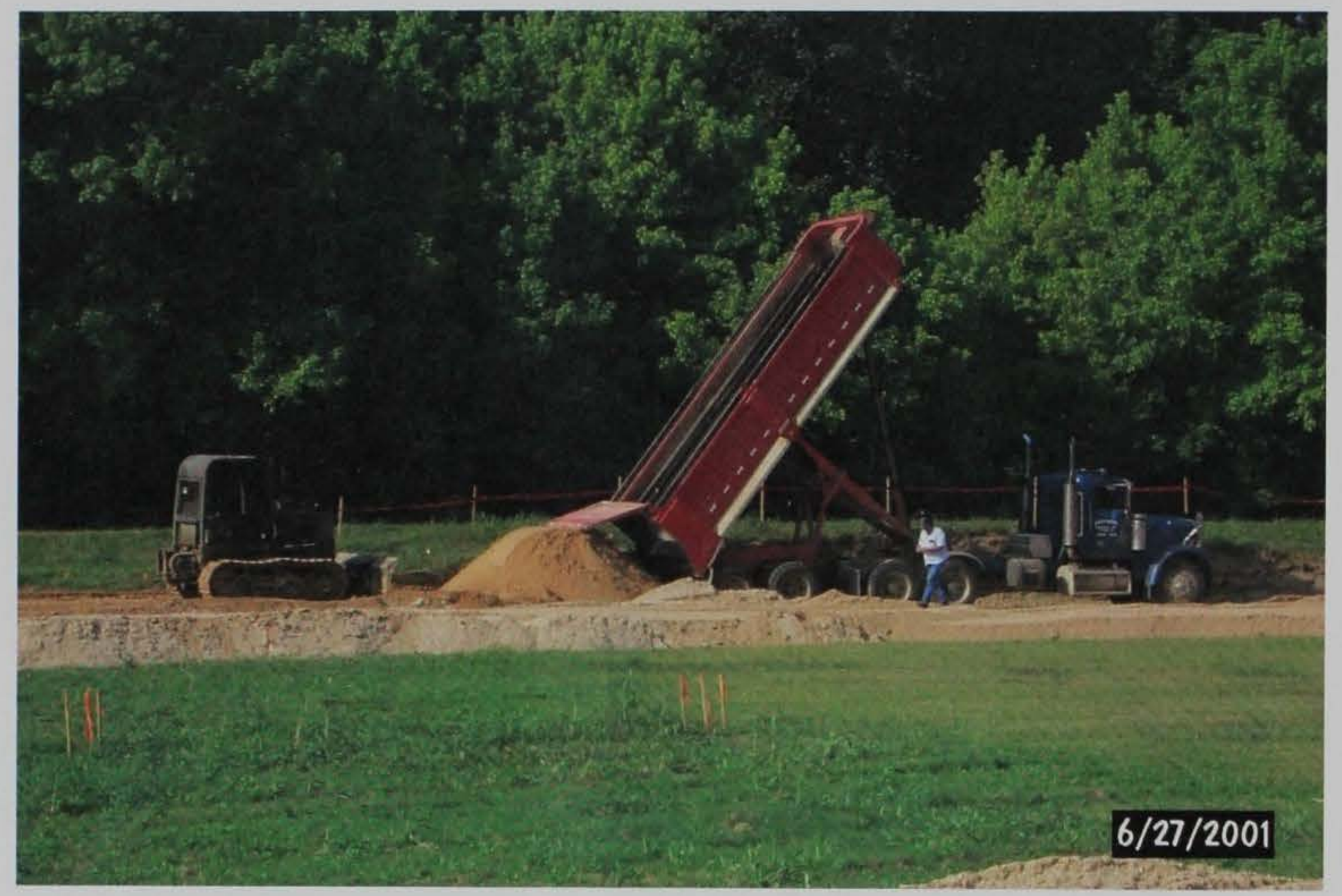

Photo 15. Placement of the sand layer

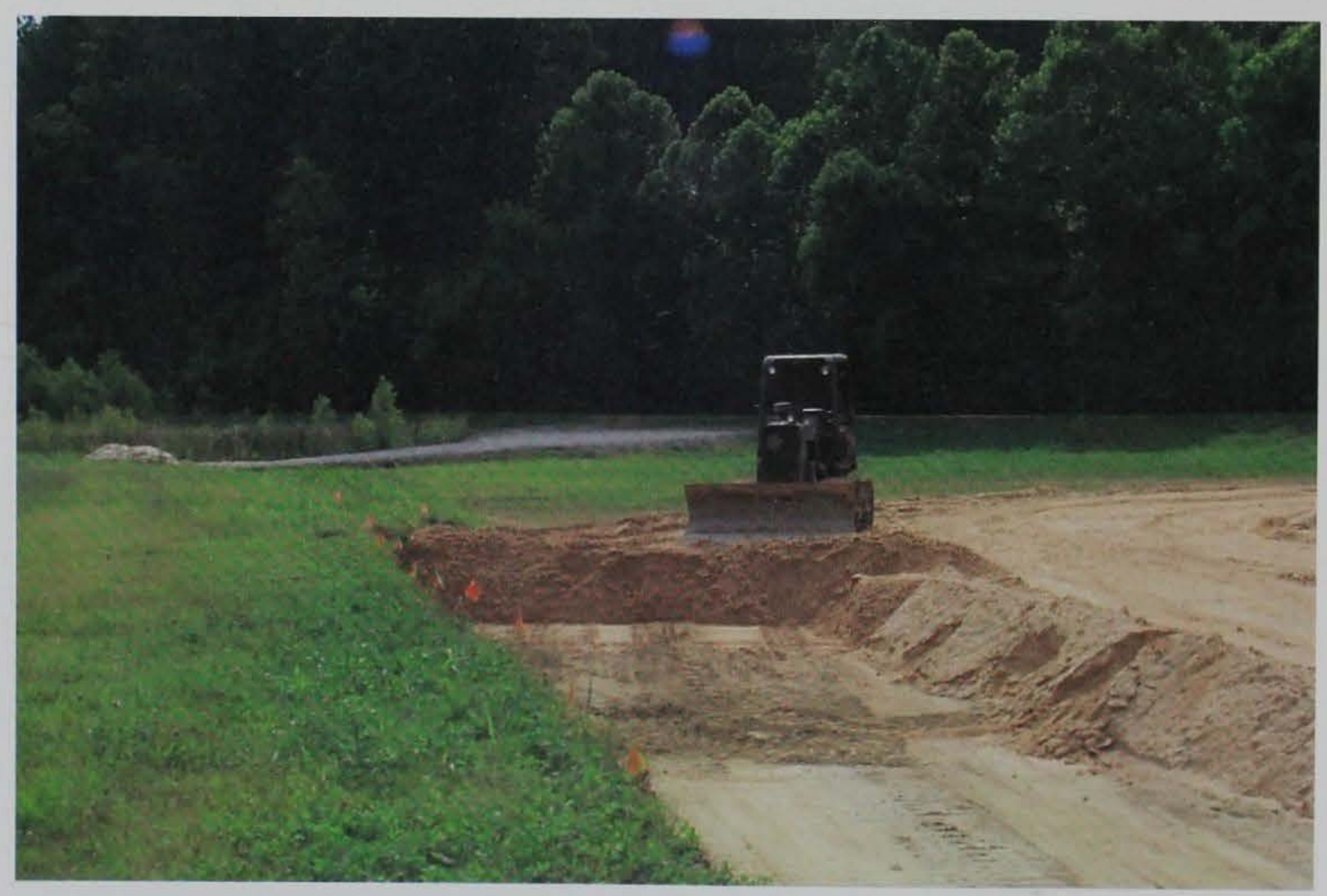

Photo 16. Back blading sand layer 


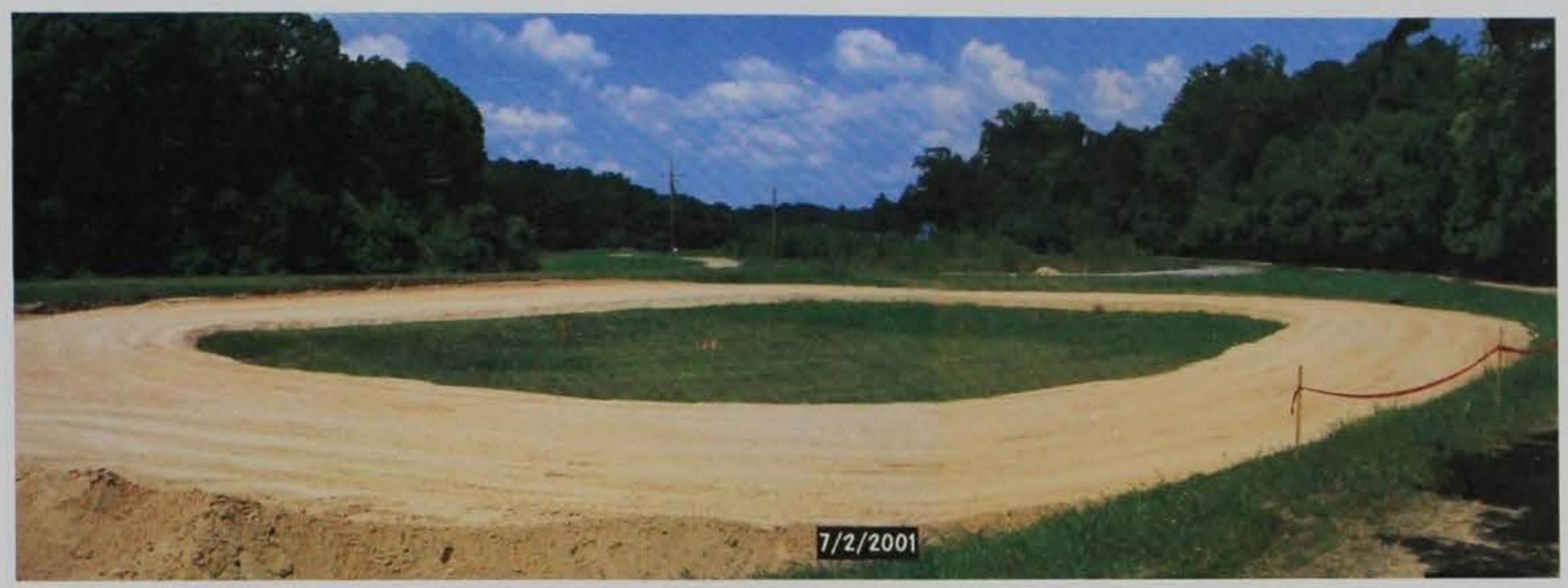

Photo 17. Overall view of the sand layer

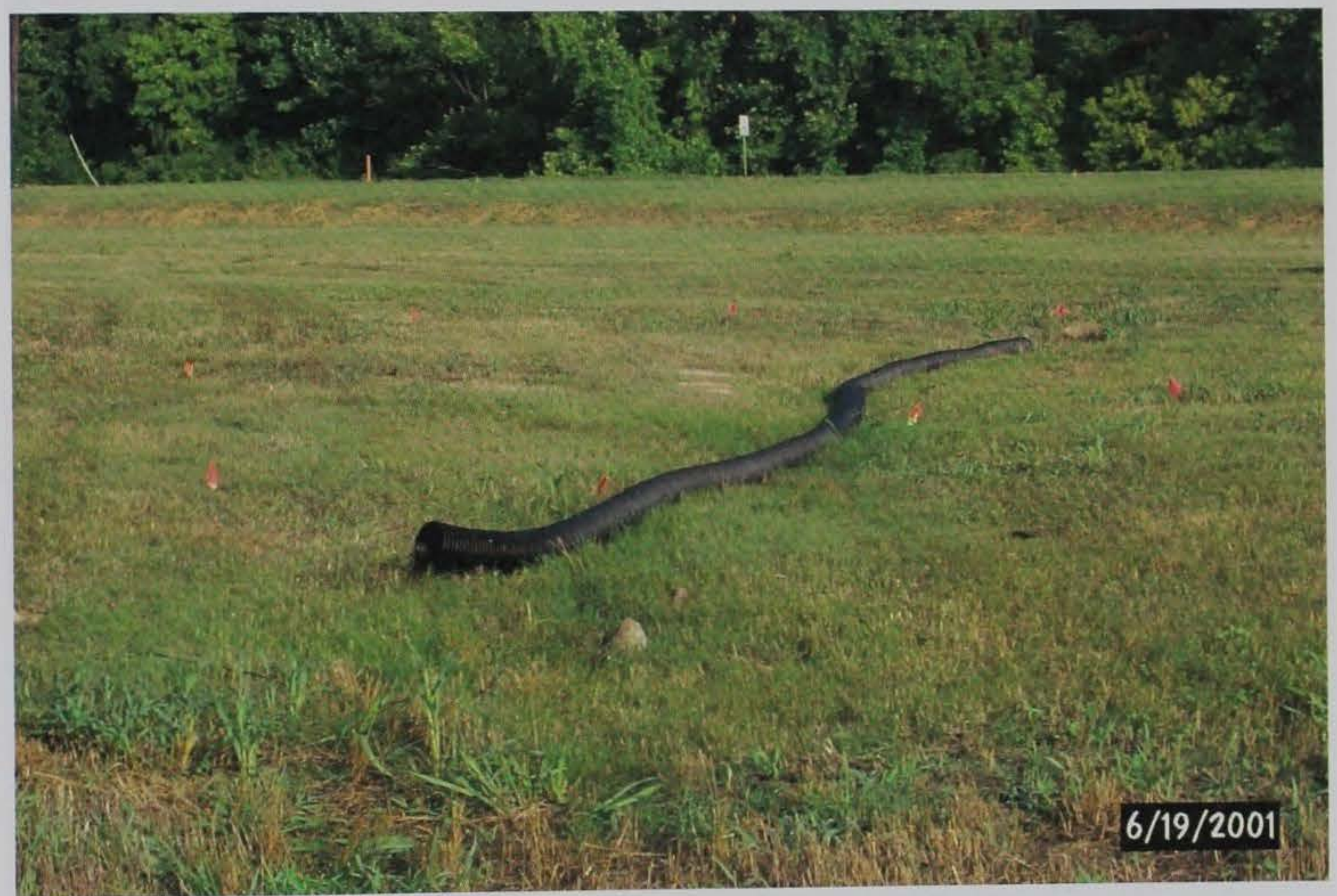

Photo 18. Placement of the drainage pipe 


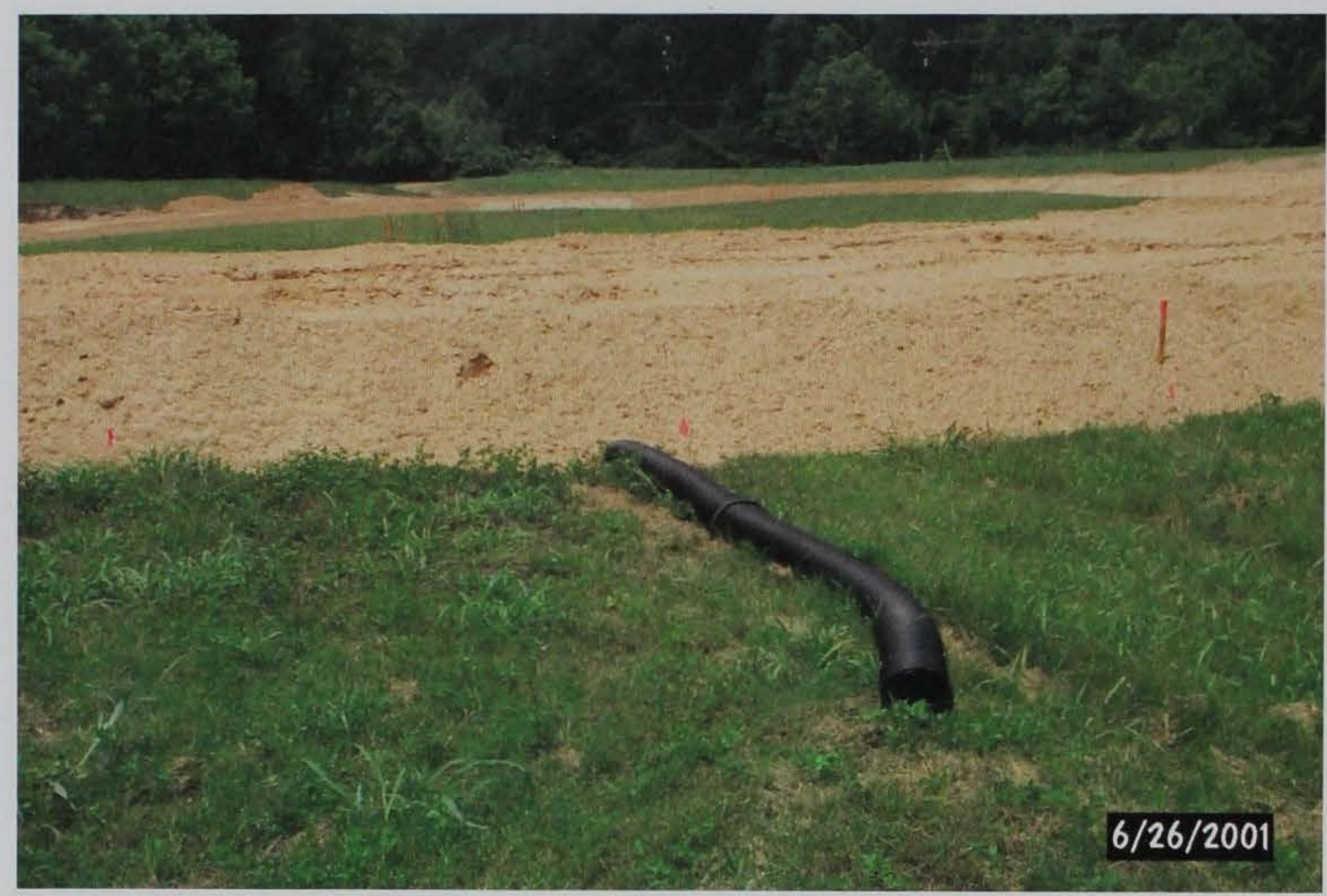

Photo 19. Pipe under the sand layer

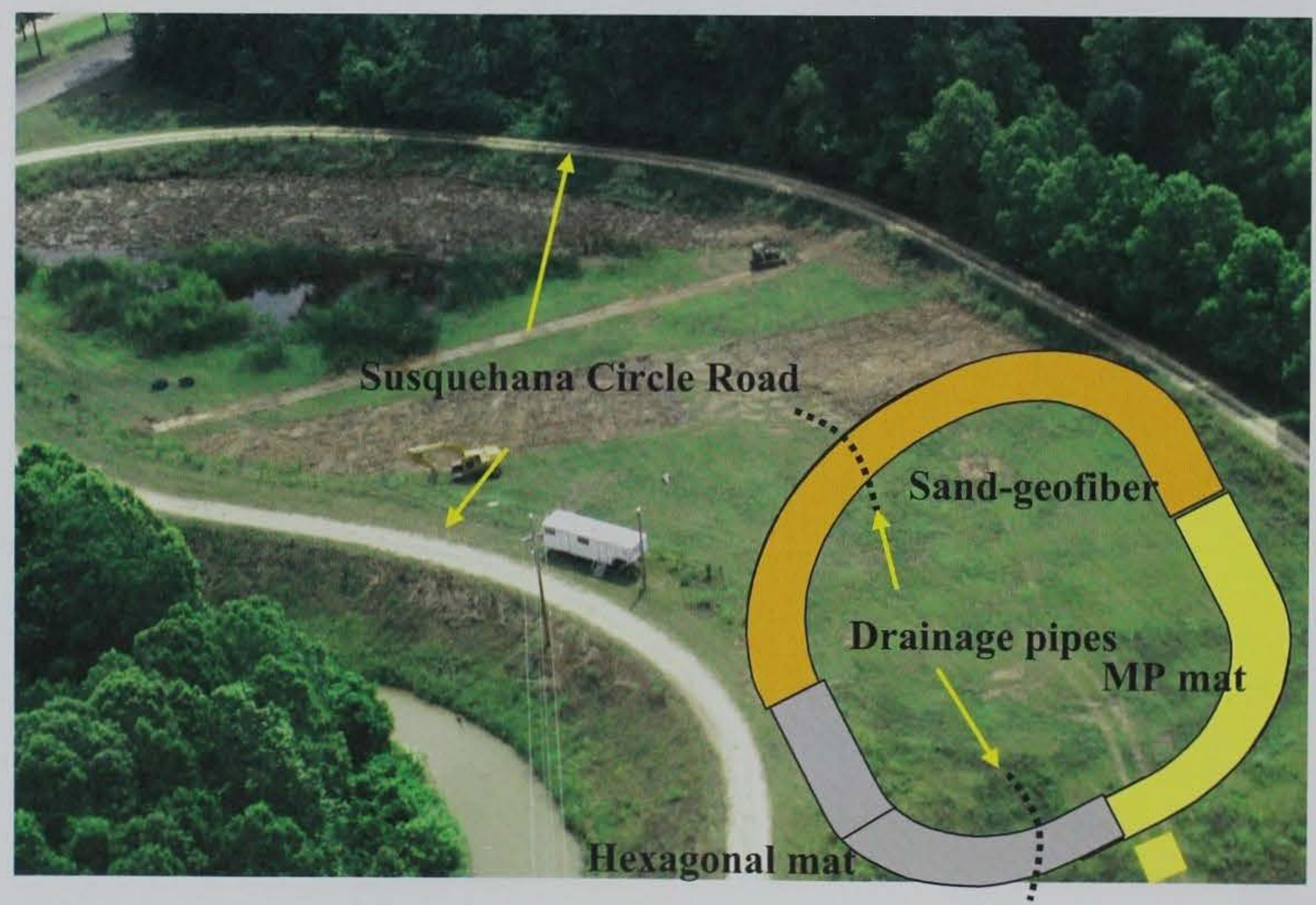

Photo 20. Aerial view of experiment site 


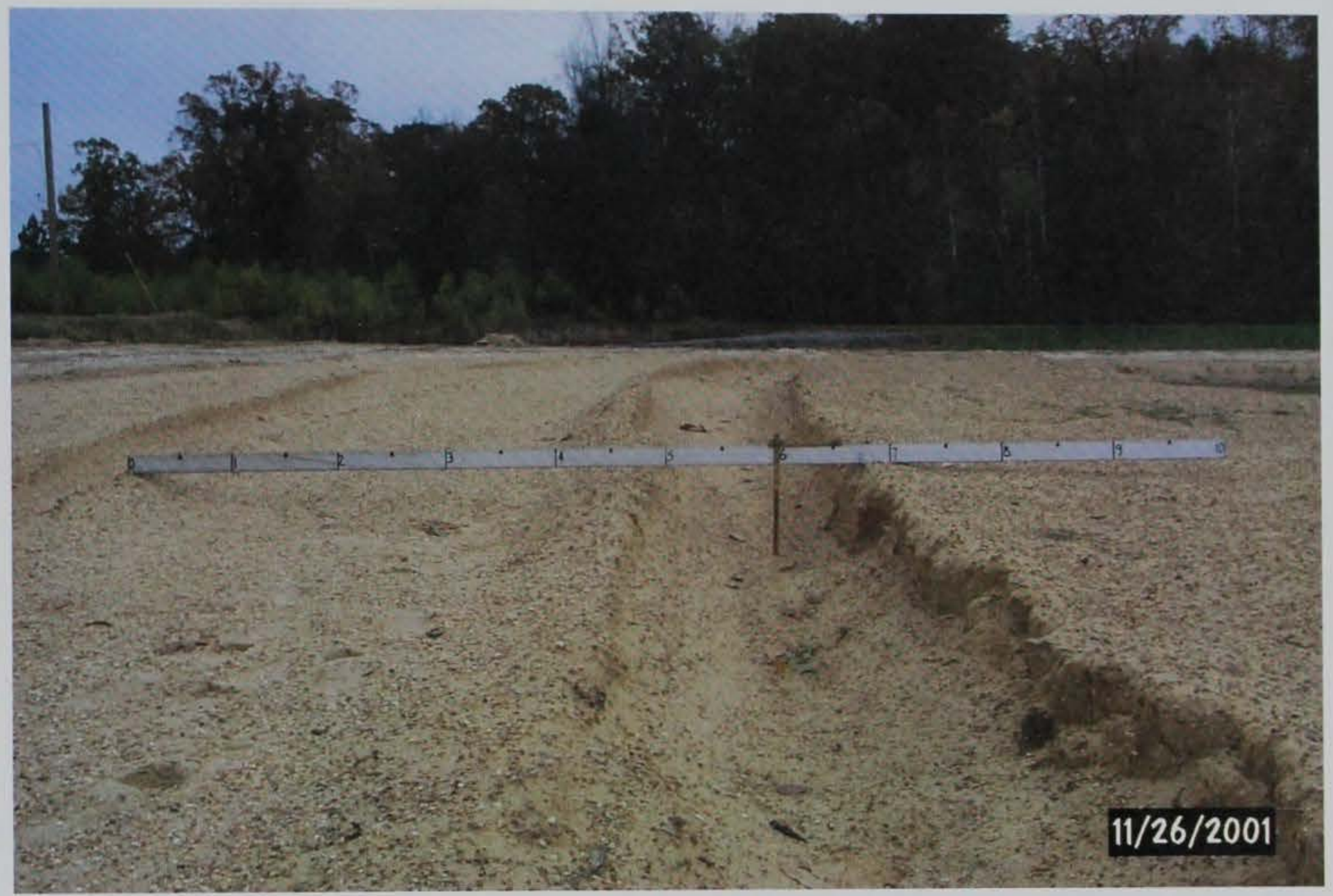

Photo 21. Loose sand layer after 10 passes of 5-ton military truck

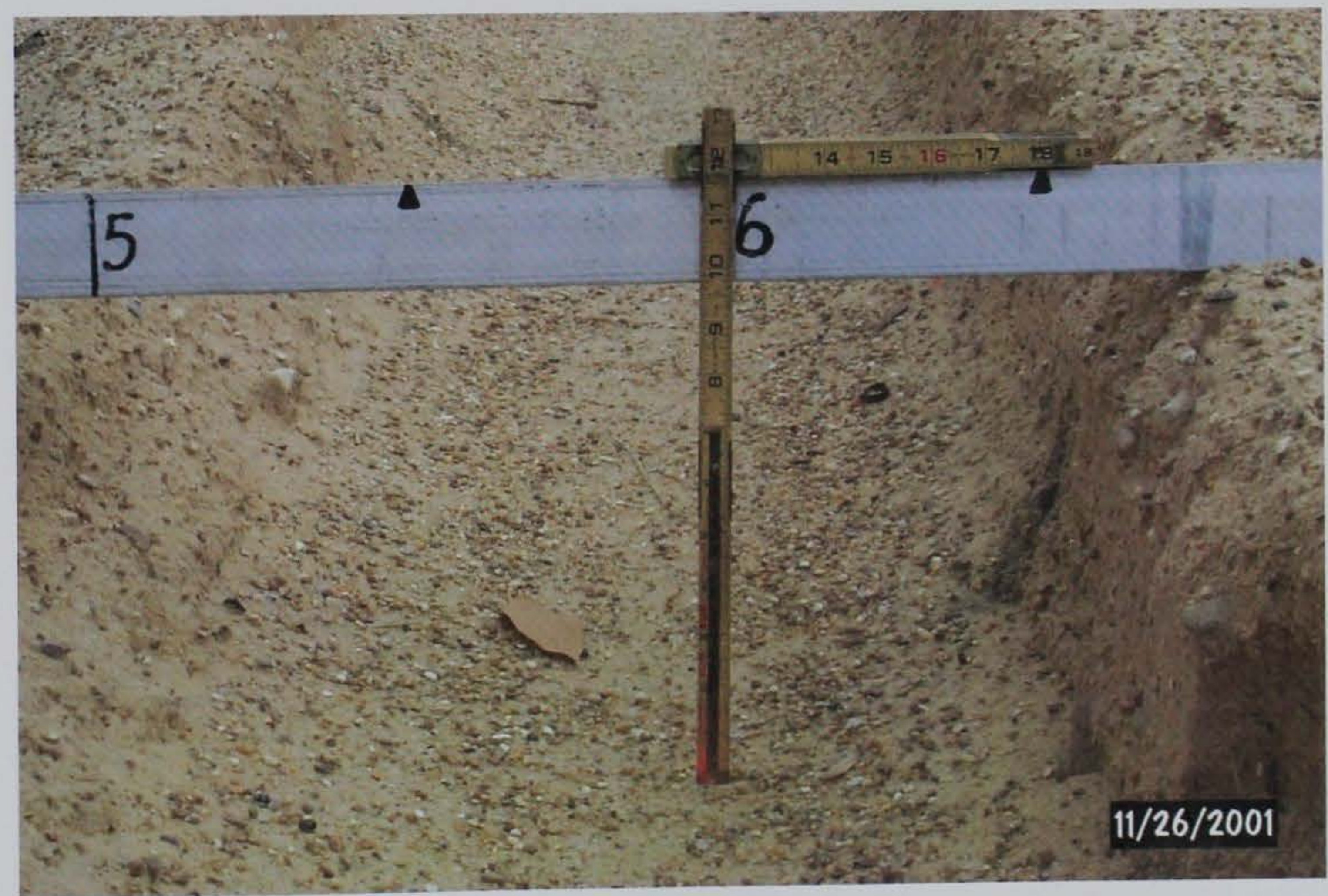

Photo 22. Close up 10 in. rut depth after 10 passes of 5 -ton military truck 


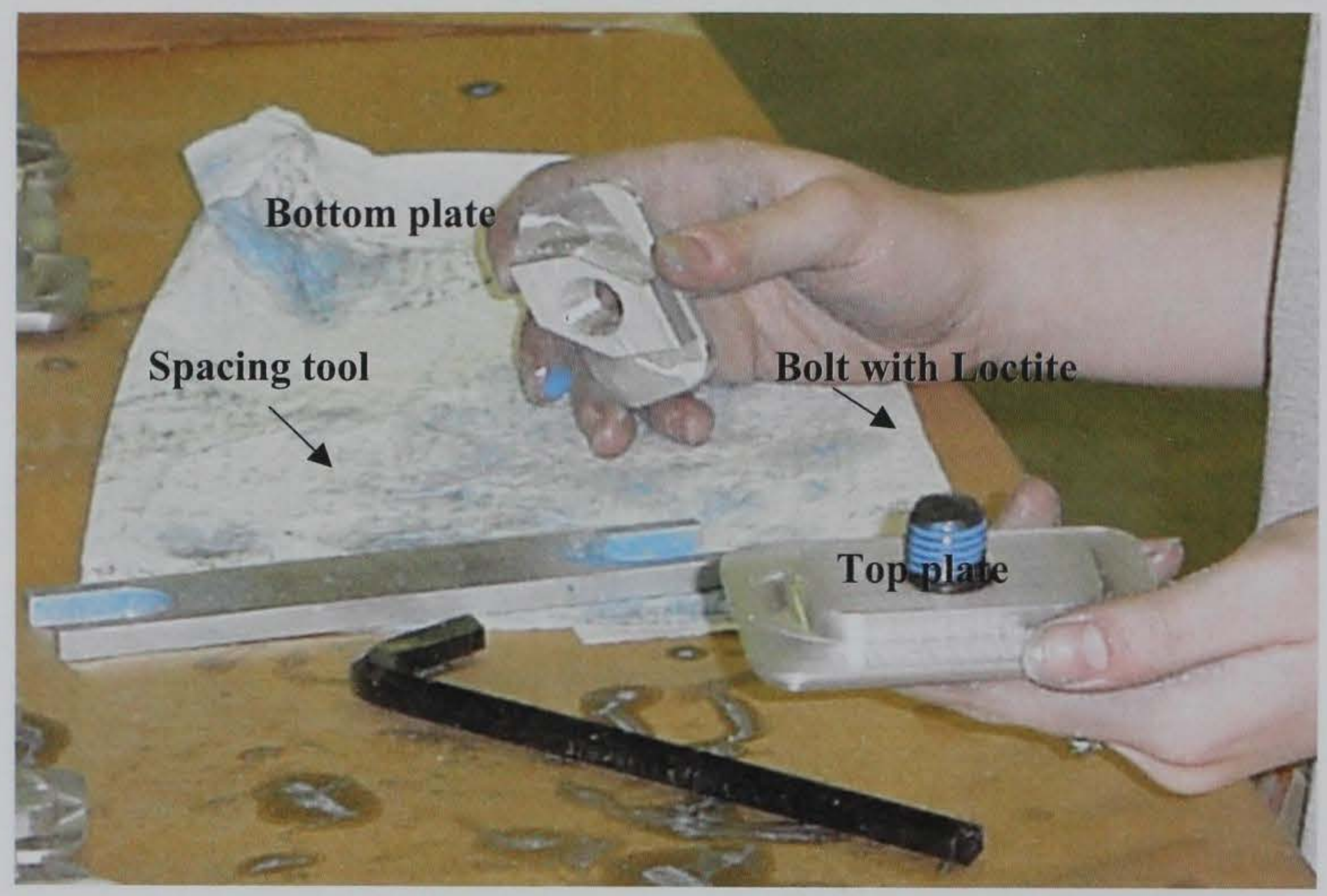

Photo 23. Assembling top and bottom plates of the connector pin

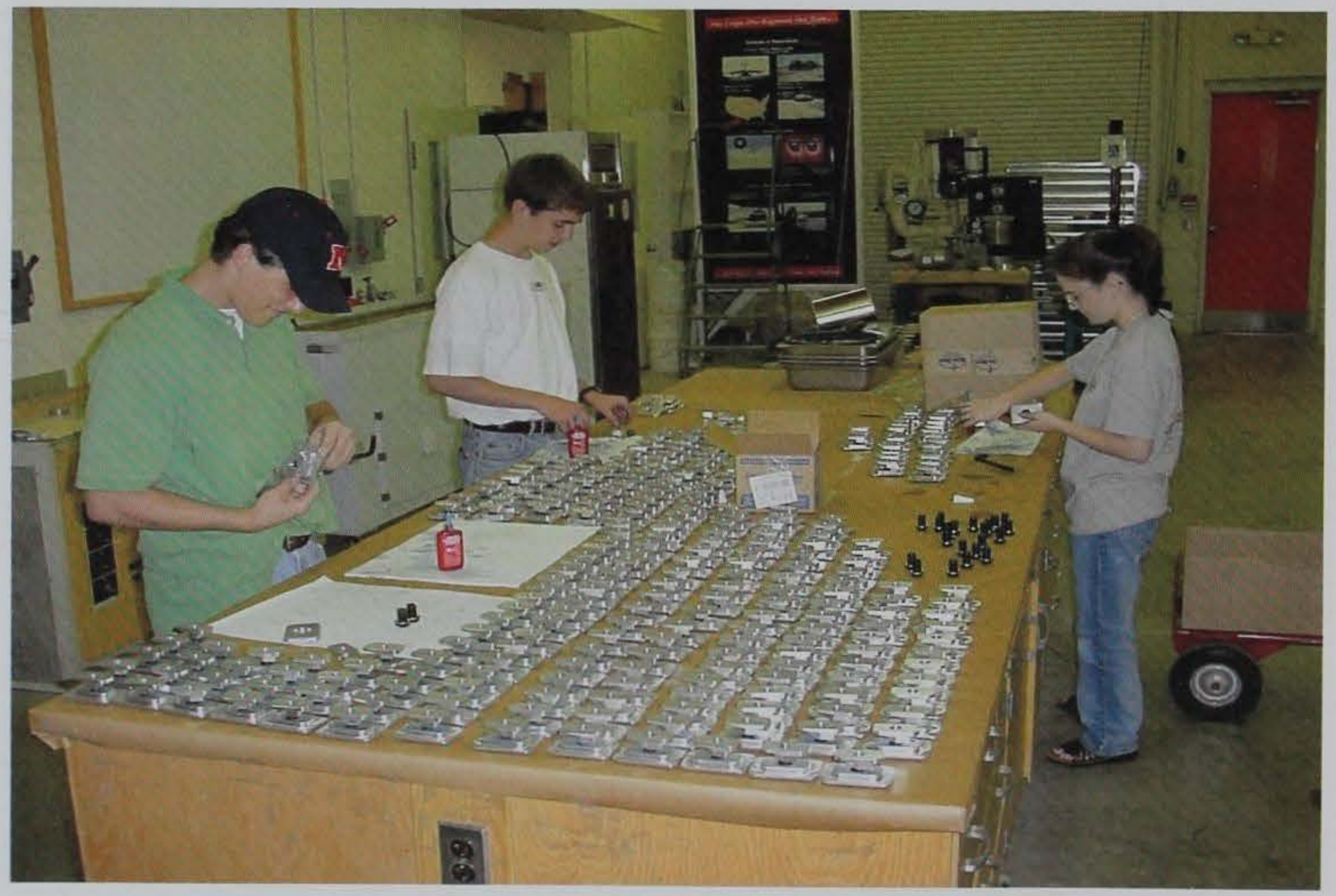

Photo 24. Connector pin assembly line 


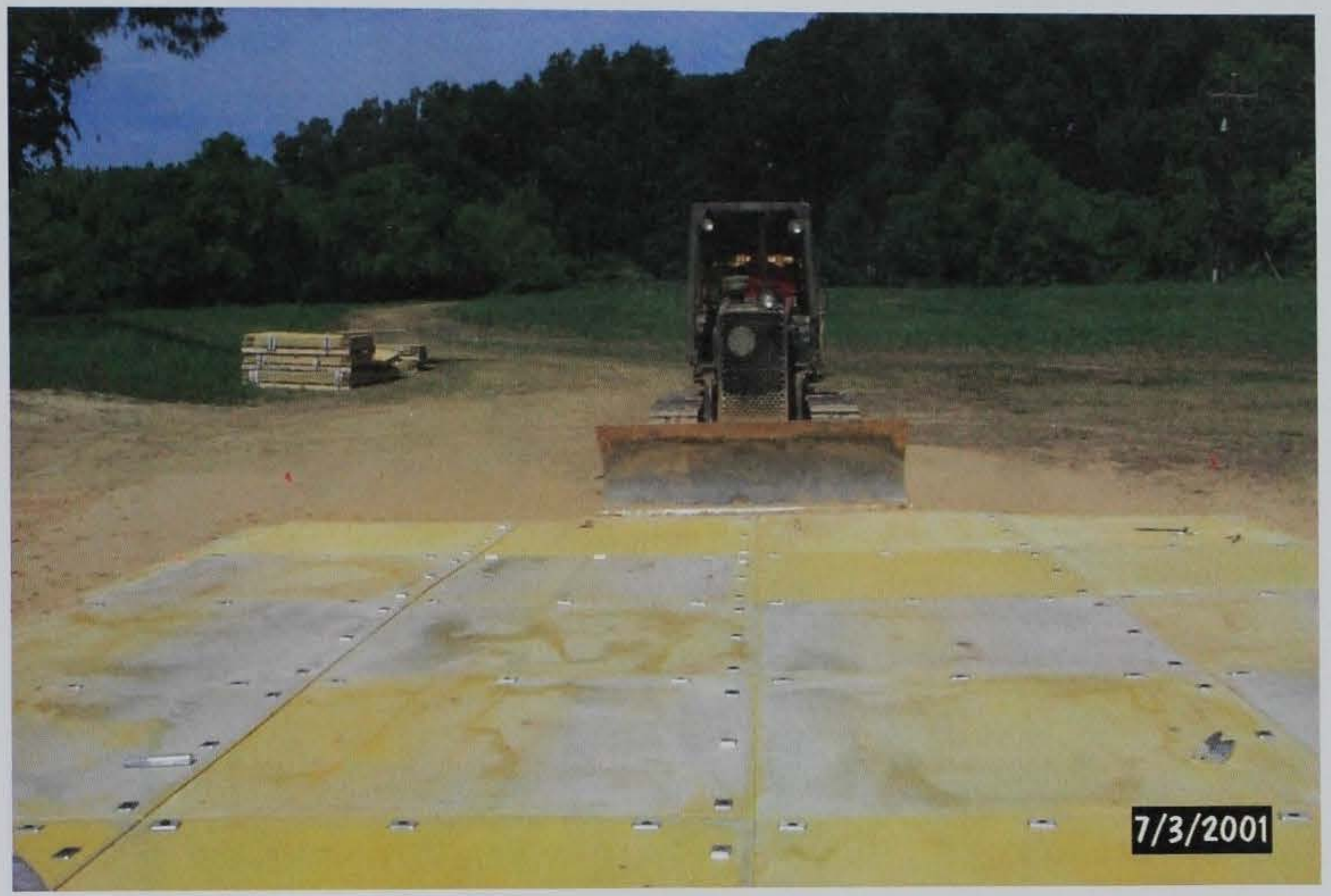

Photo 25. MP mat access ramp connection to the main Item 1 sections

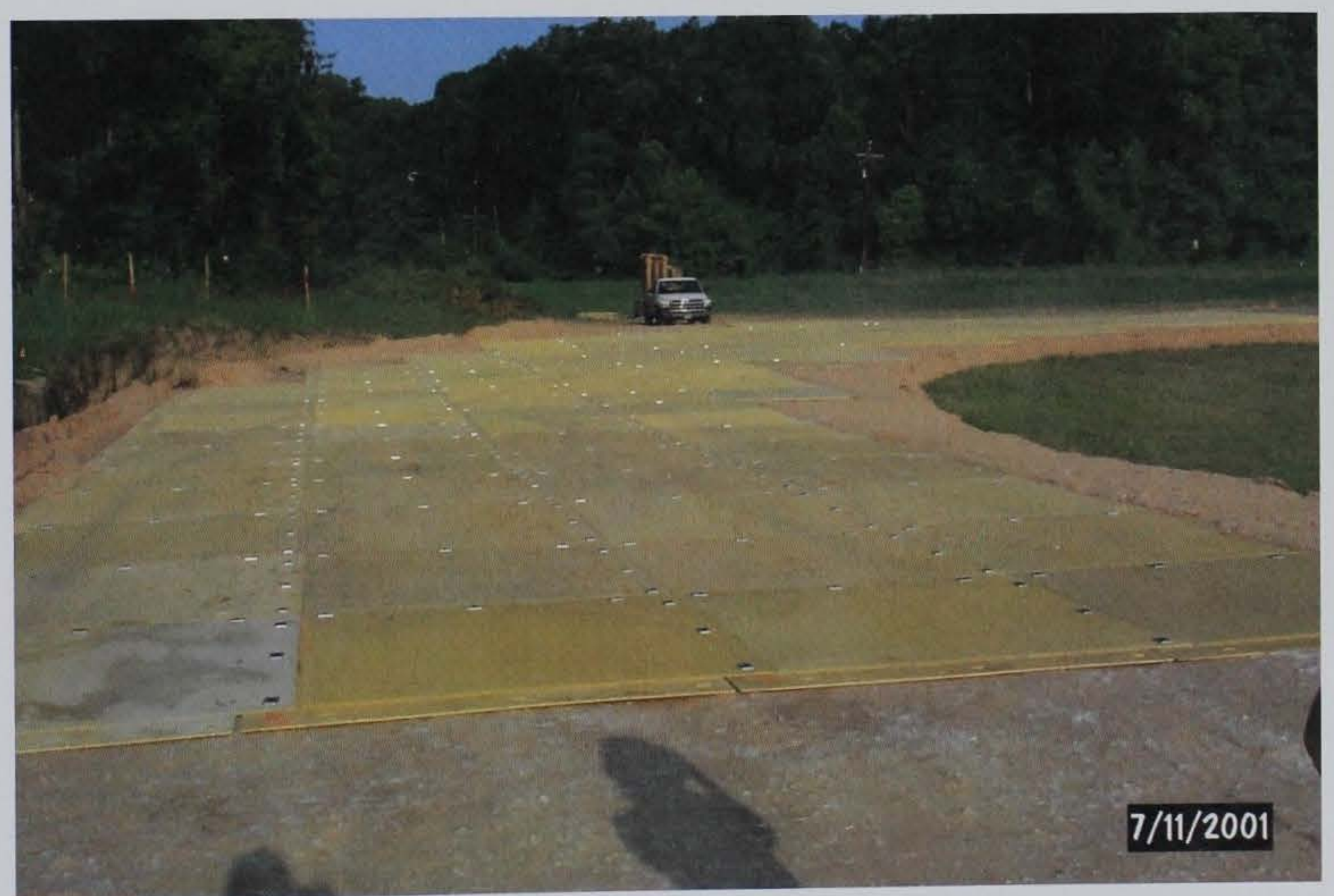

Photo 26. Item 1 straight section 


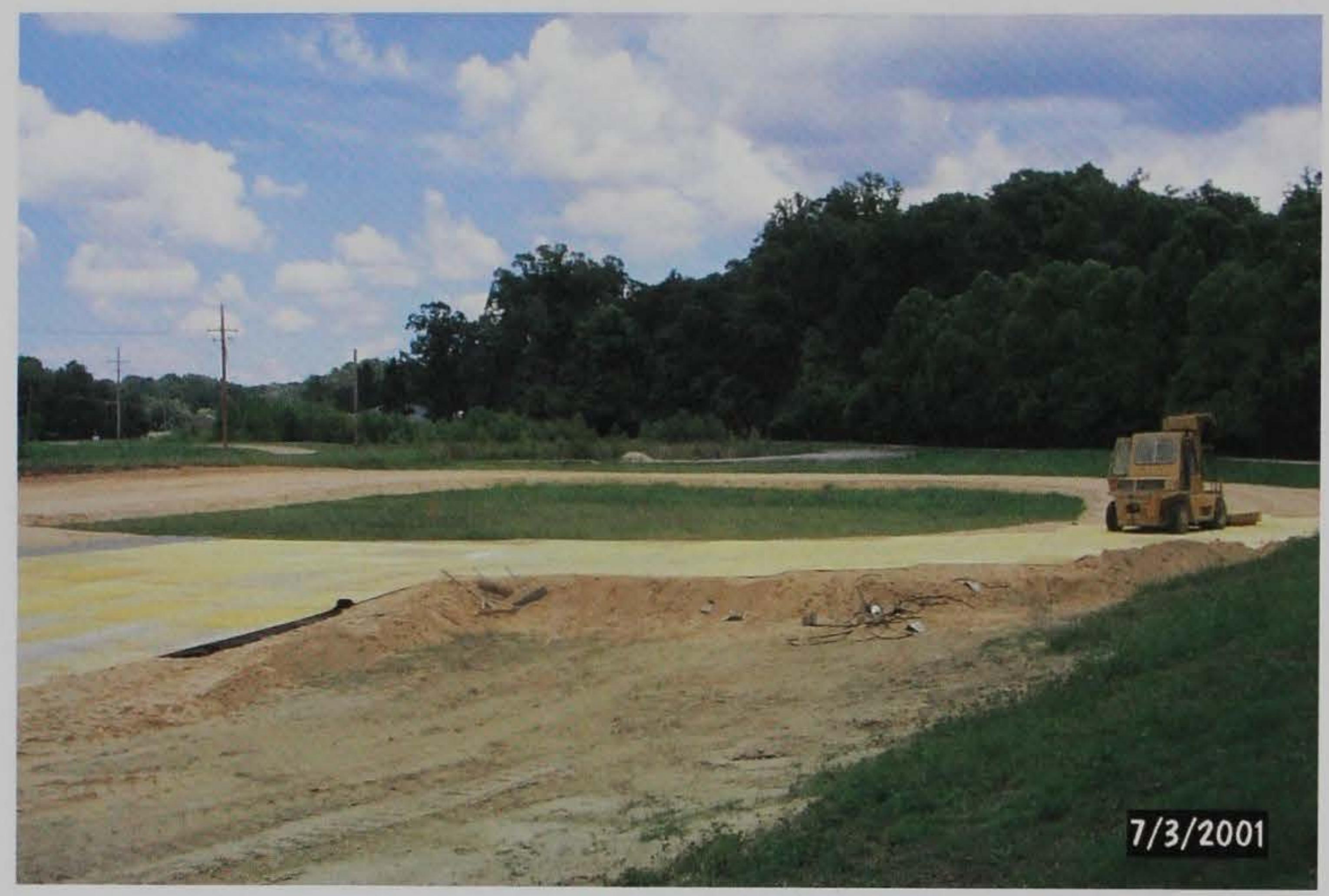

Photo 27 . Item $150-\mathrm{ft}$ radius curve section

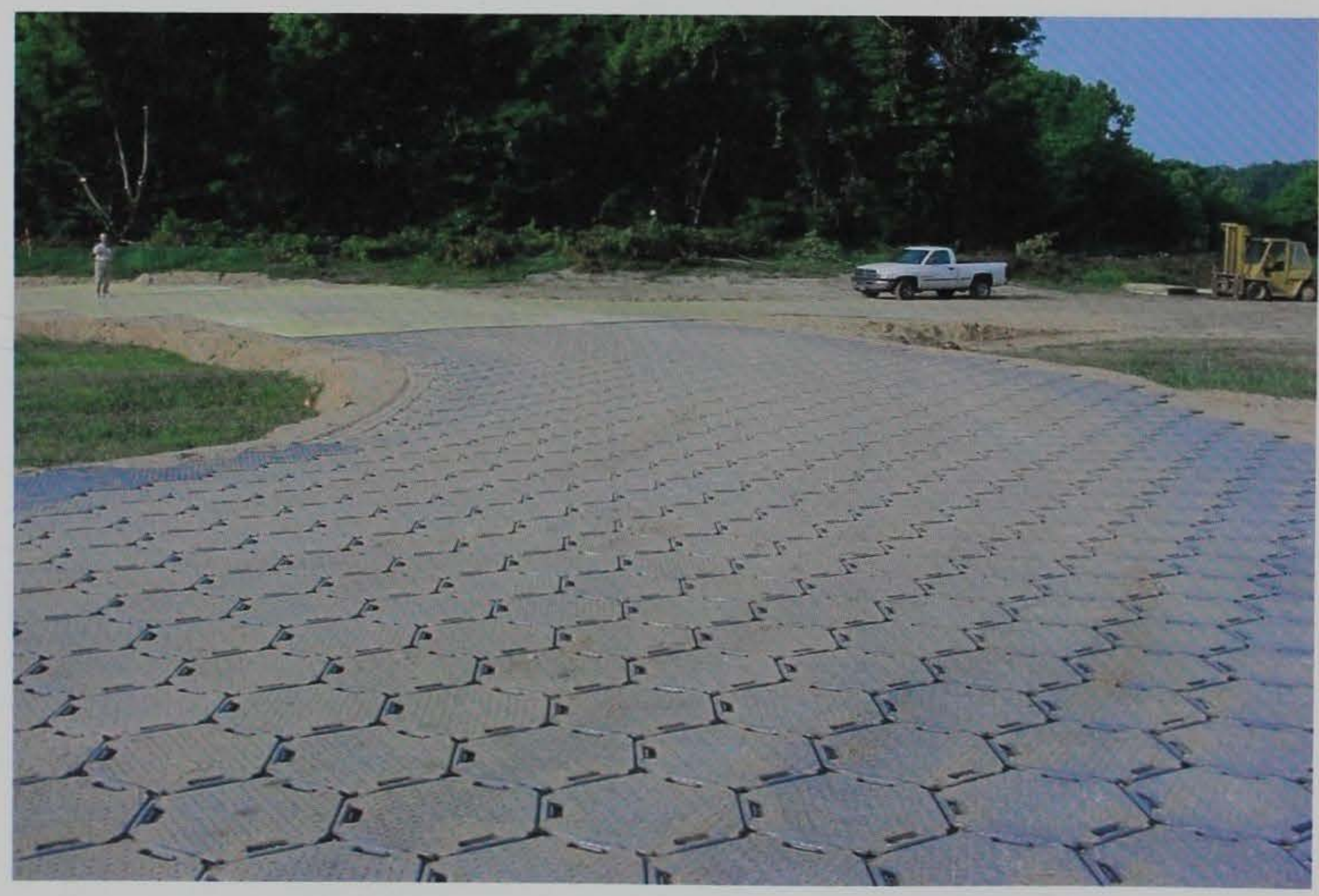

Photo 28. Item 250 -ft radius curve section 


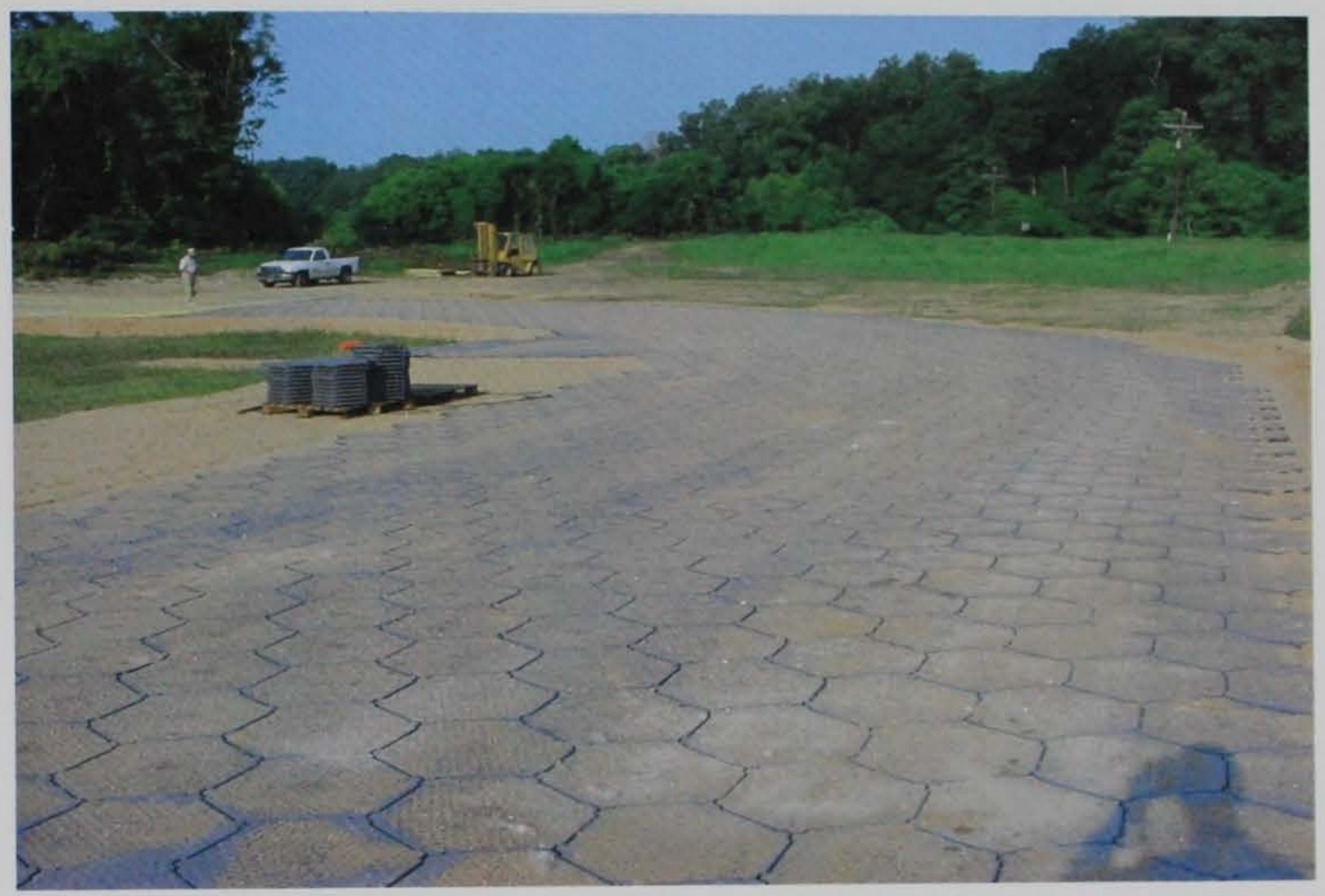

Photo 29. Item 2 Special hexagonal plastic mat section

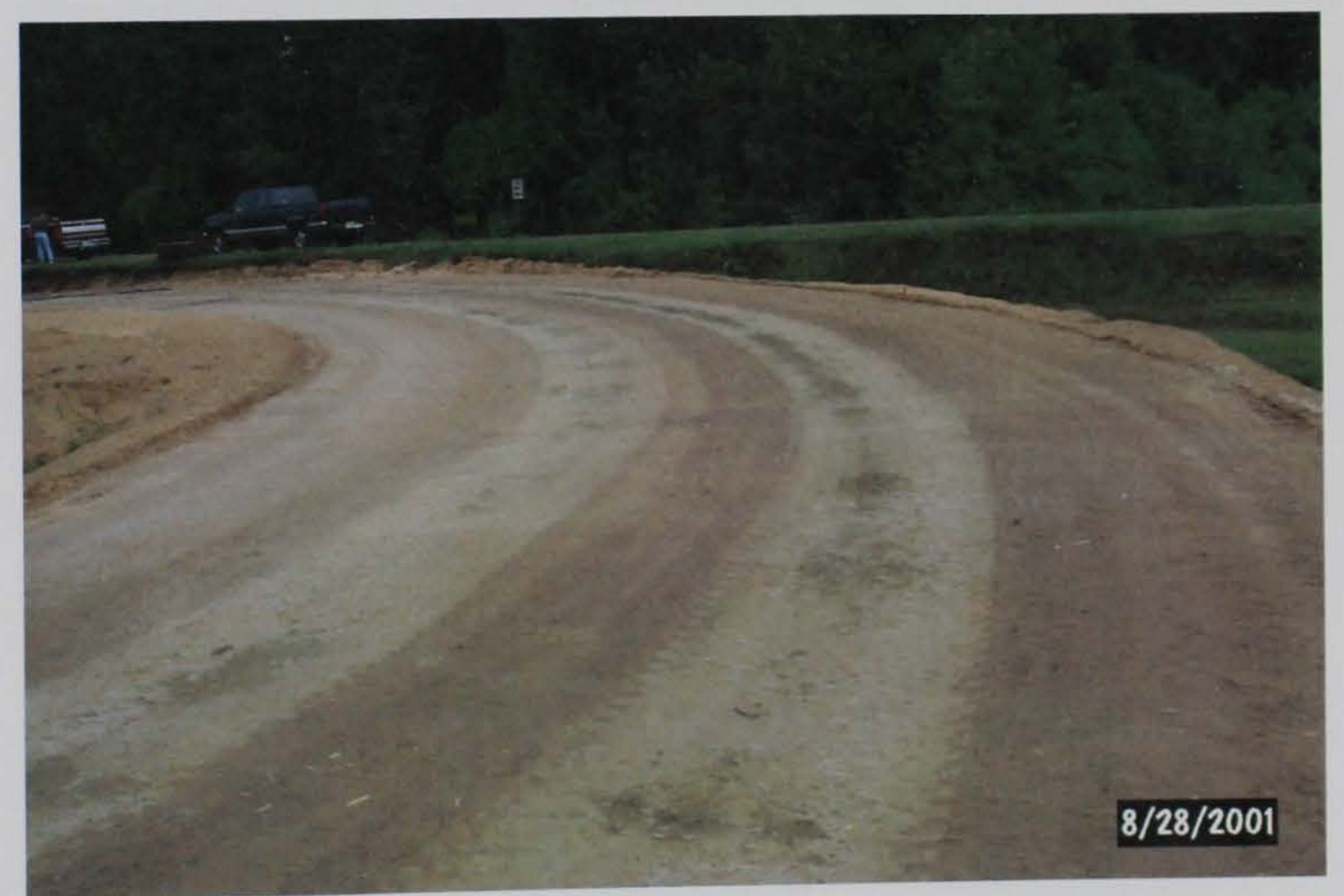

Photo 30 . Item 375 - $\mathrm{ft}$ radius curve section 


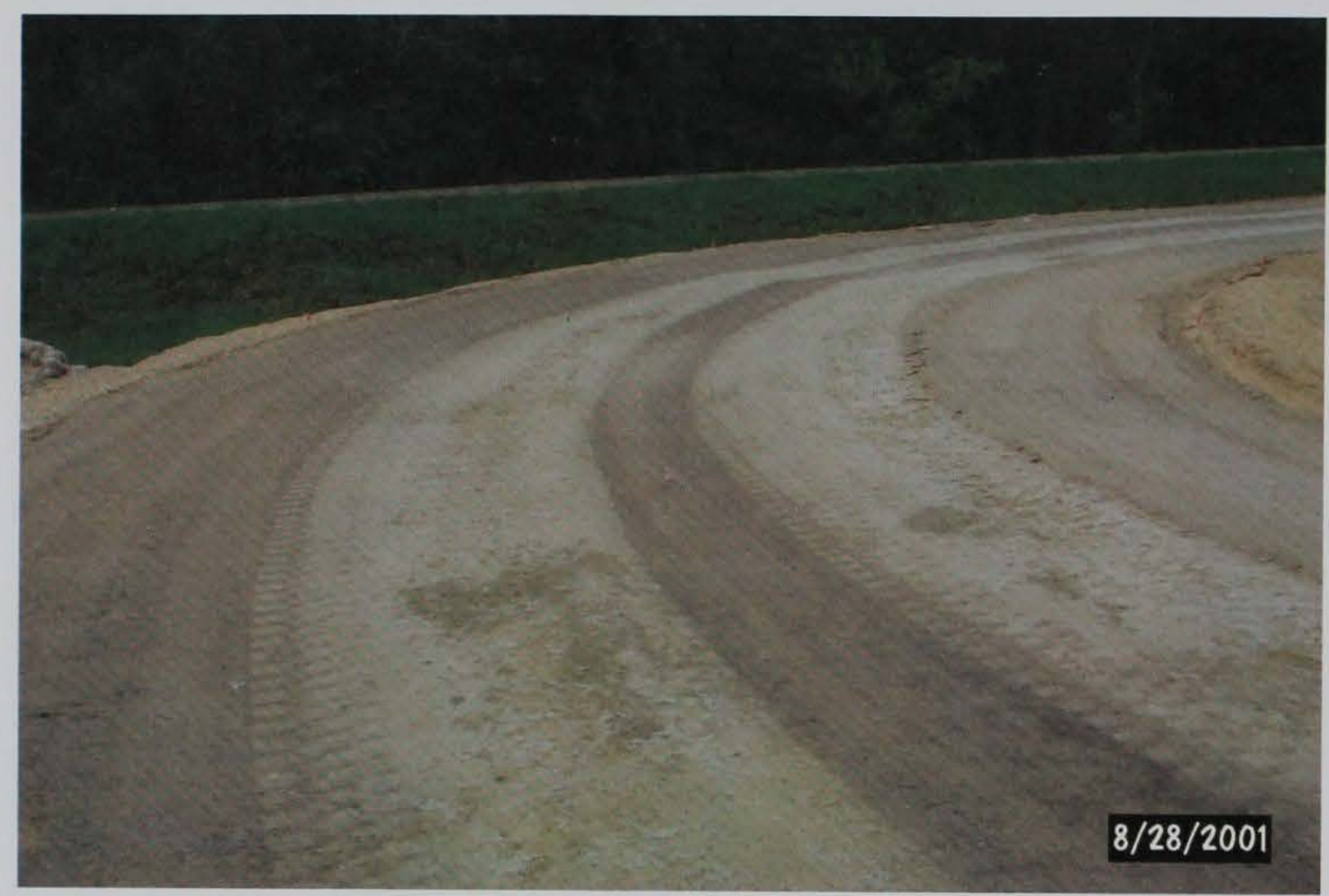

Photo 31 . Item $350-\mathrm{ft}$ radius curve section

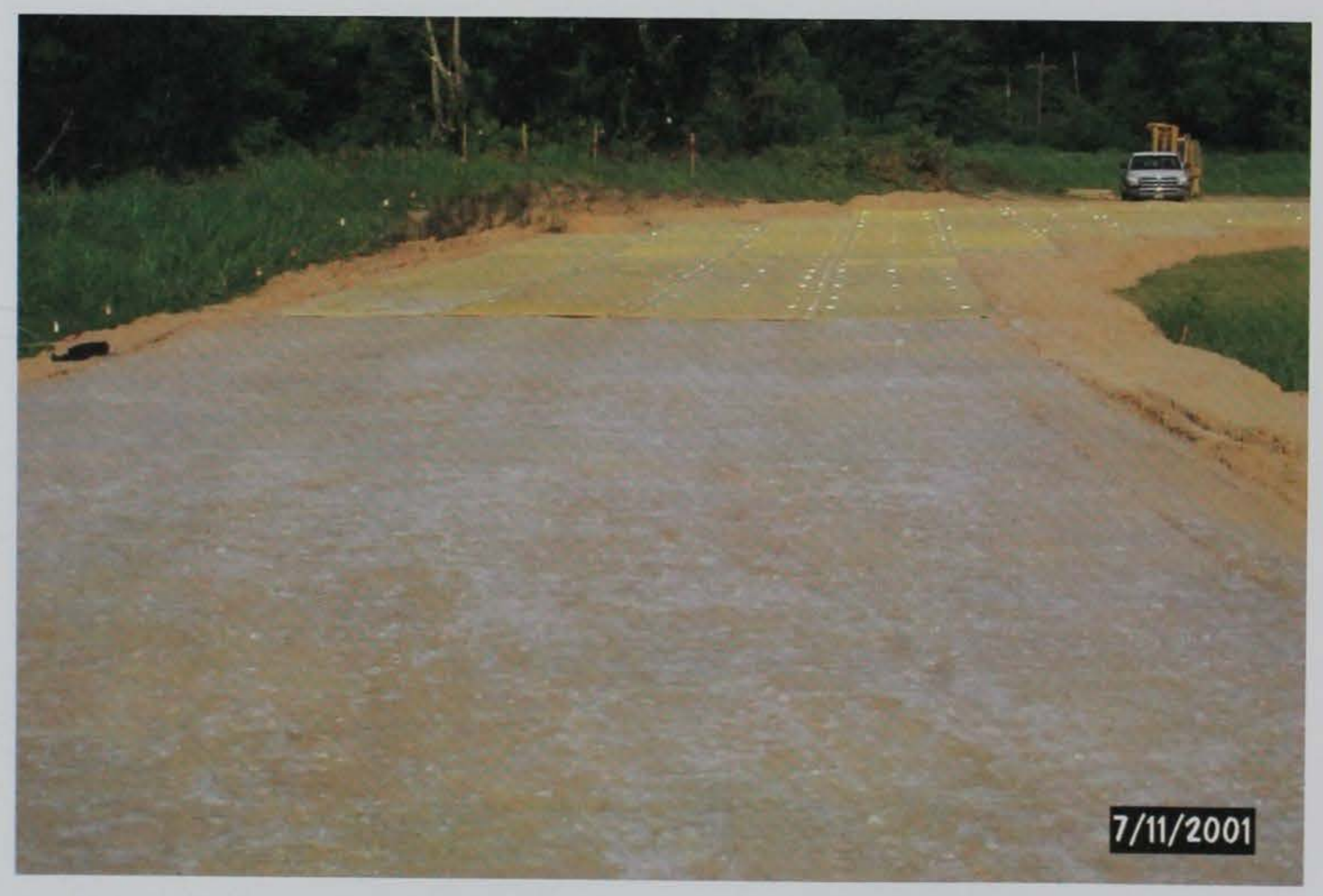

Photo 32. Item 3 straight section 


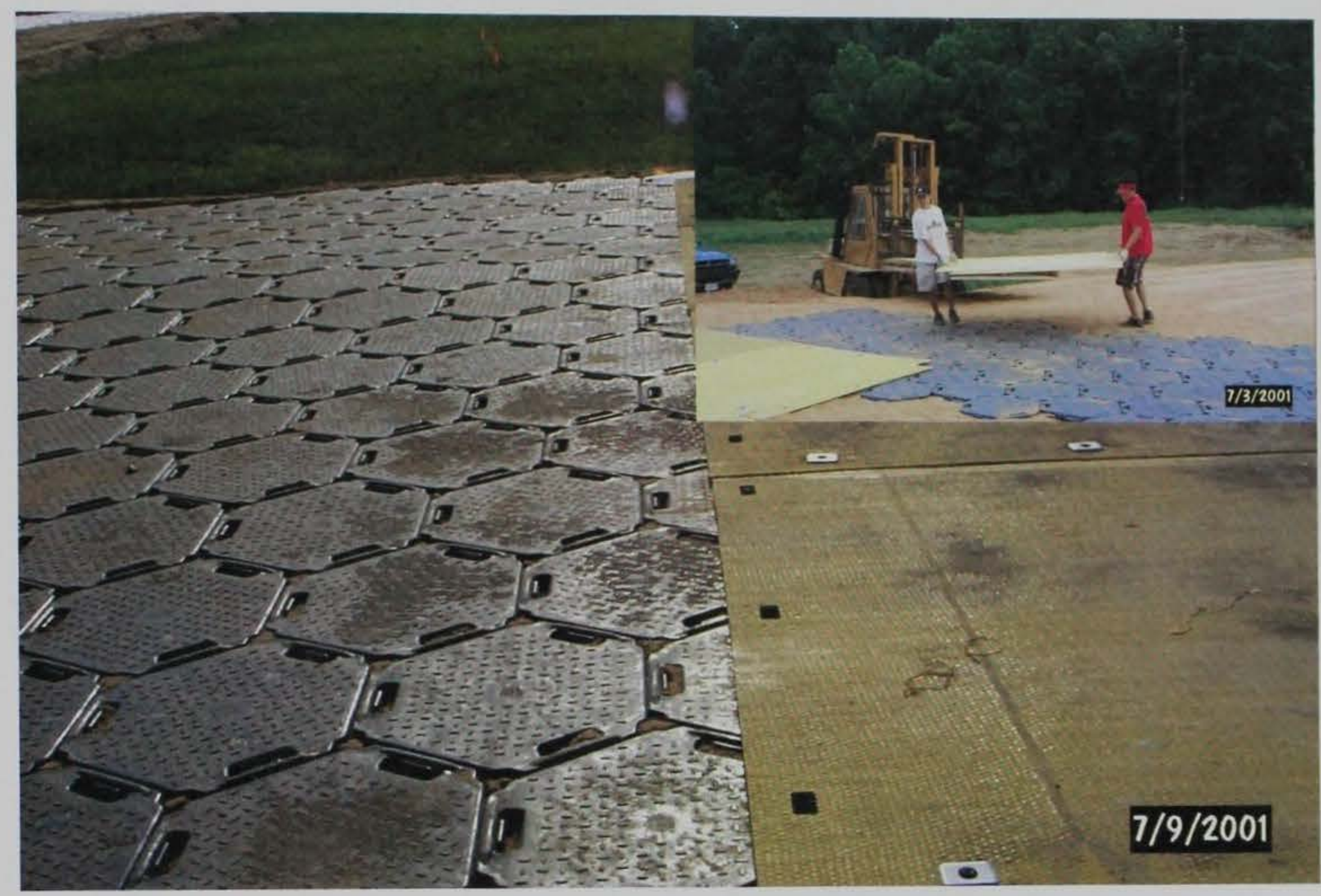

Photo 33. MP mat 50-ft radius curve section and Allround hexagonal plastic mat transition zone

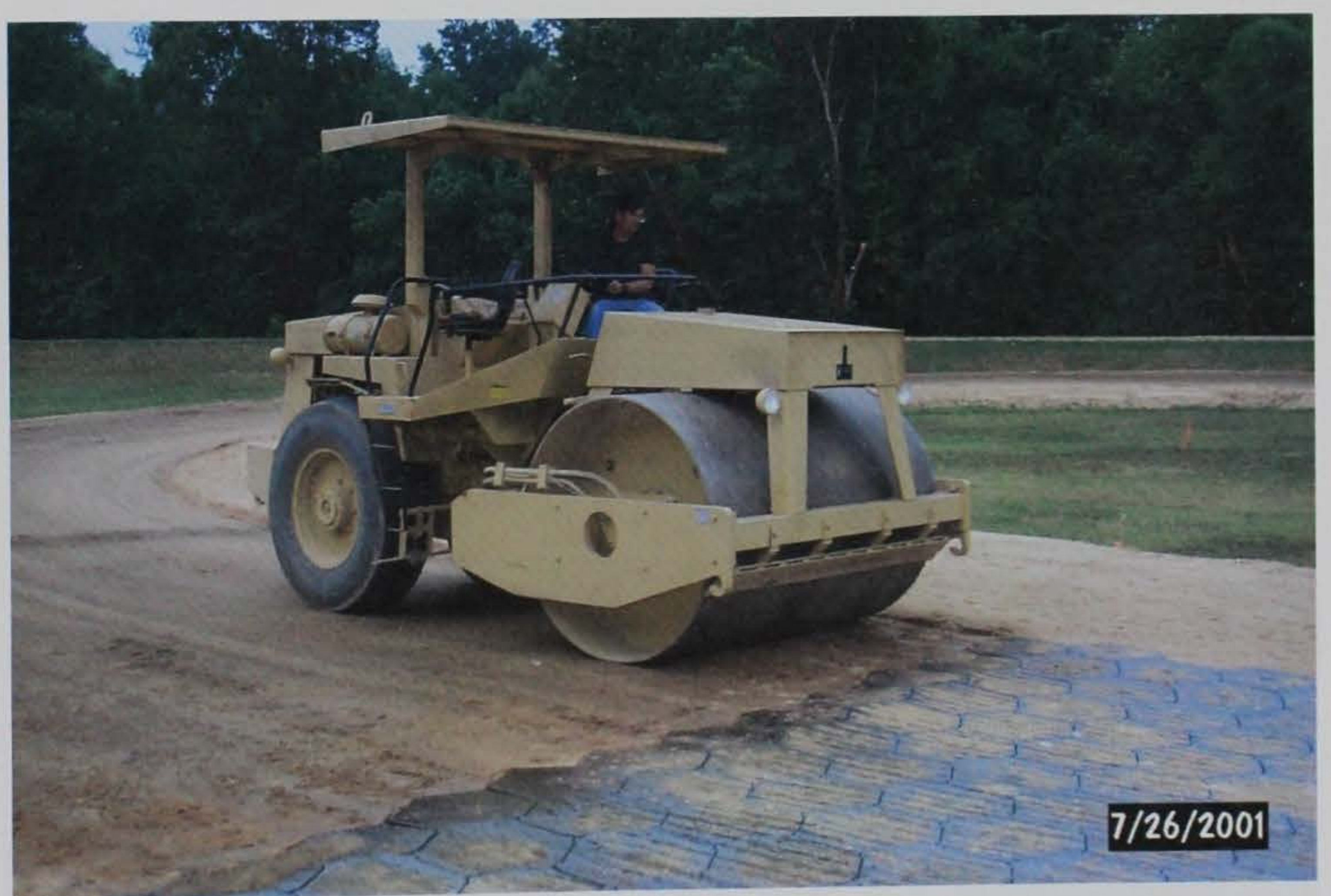

Photo 34. Special hexagonal plastic mat and 75 - $\mathrm{ft}$ radius curve sand-geofiber section transition zone 


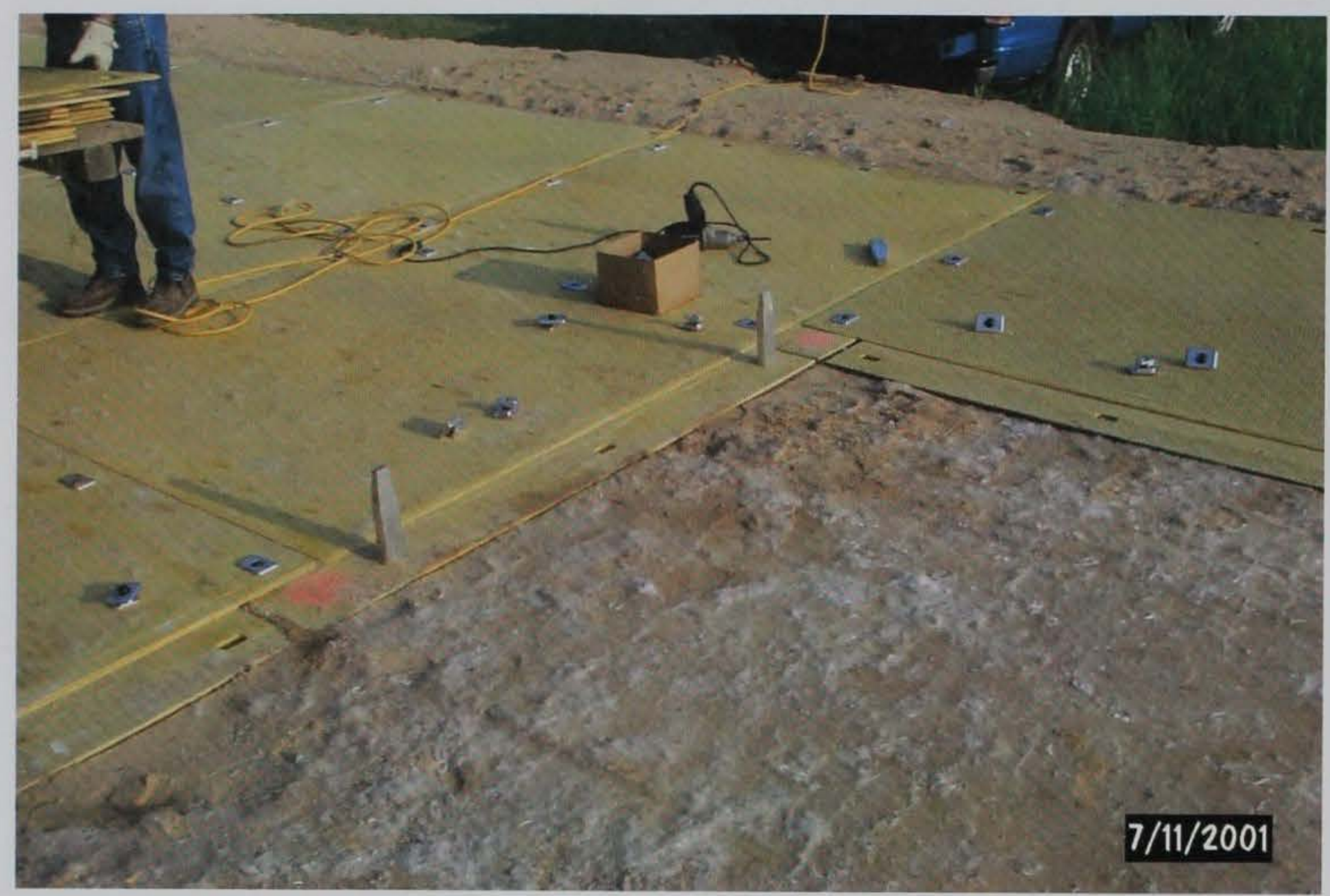

Photo 35. MP mat 50-ft radius curve section and Allround hexagonal plastic mat transition zone

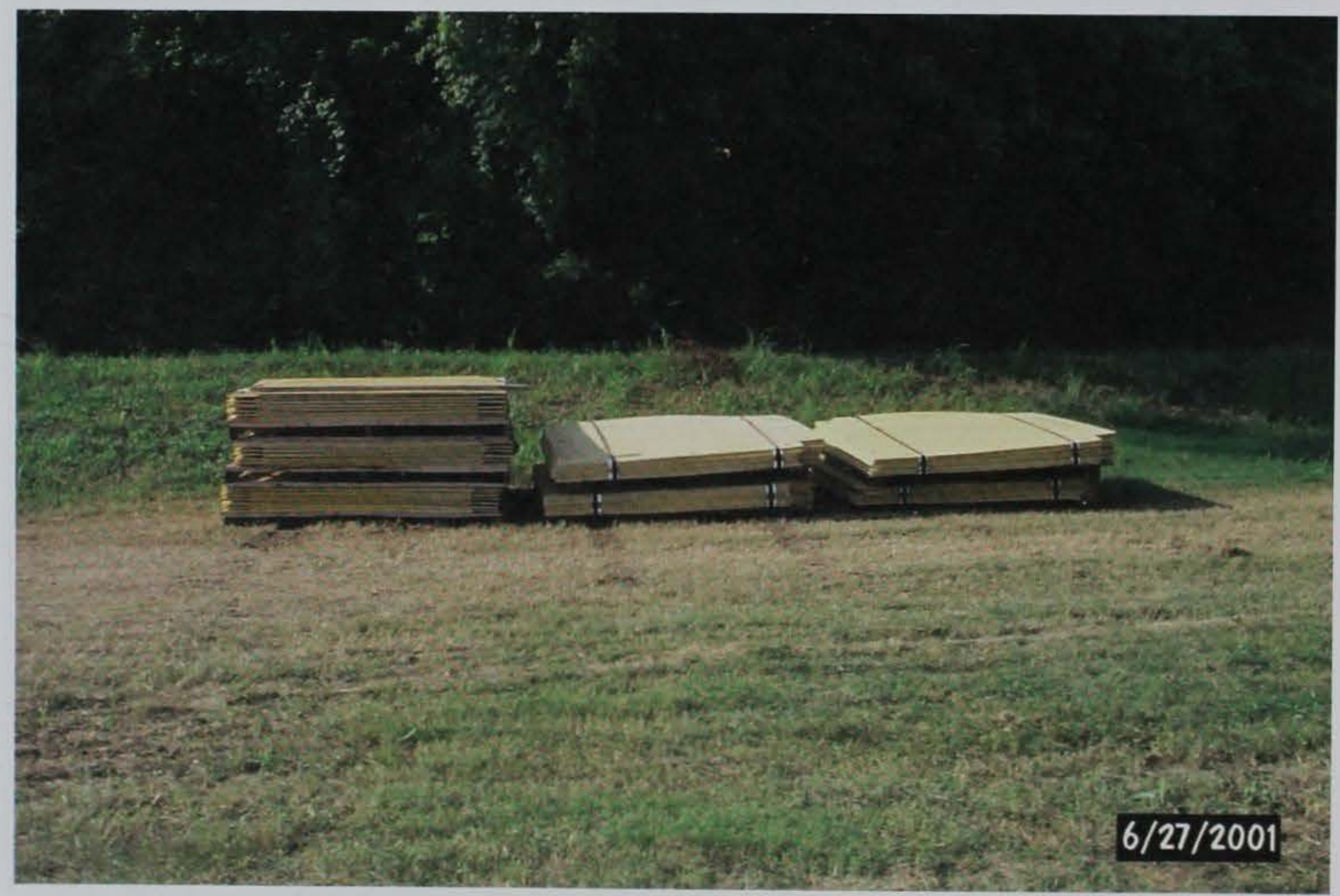

Photo 36. MP mats on shipping pallets 


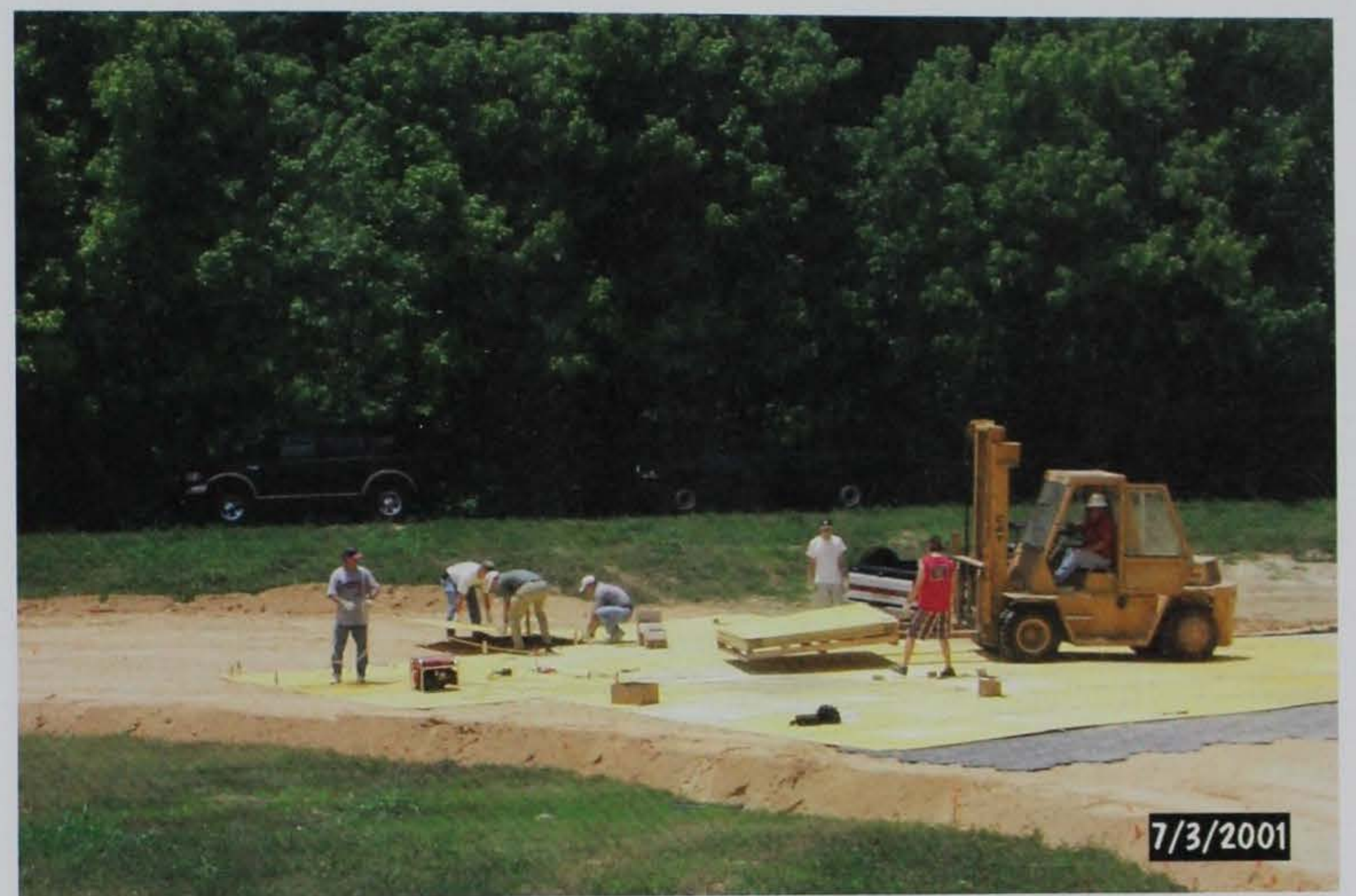

Photo 37. Forklift delivering MP mats to installation site

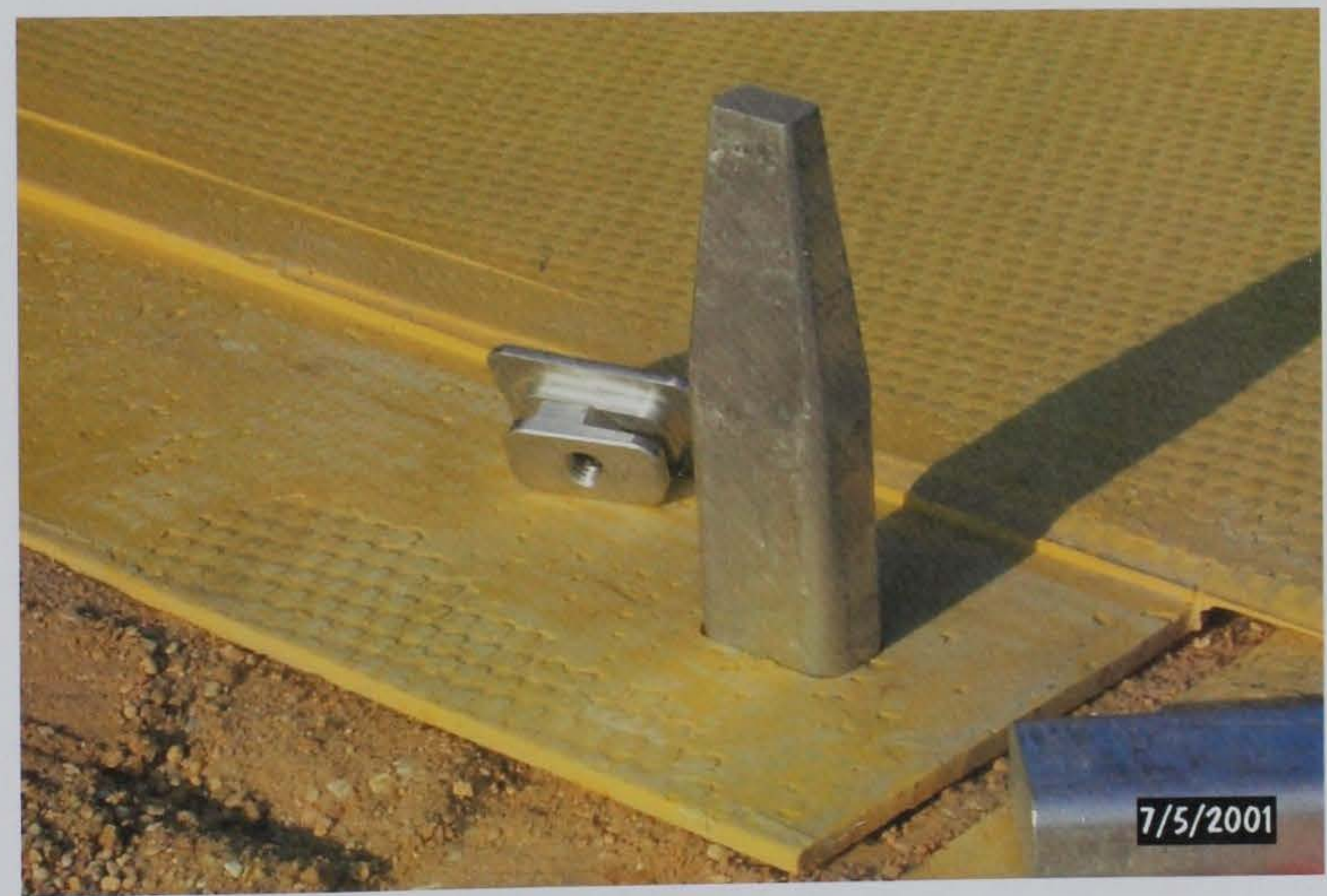

Photo 38. Close-up view of alignment tool positioned in panel ledge 


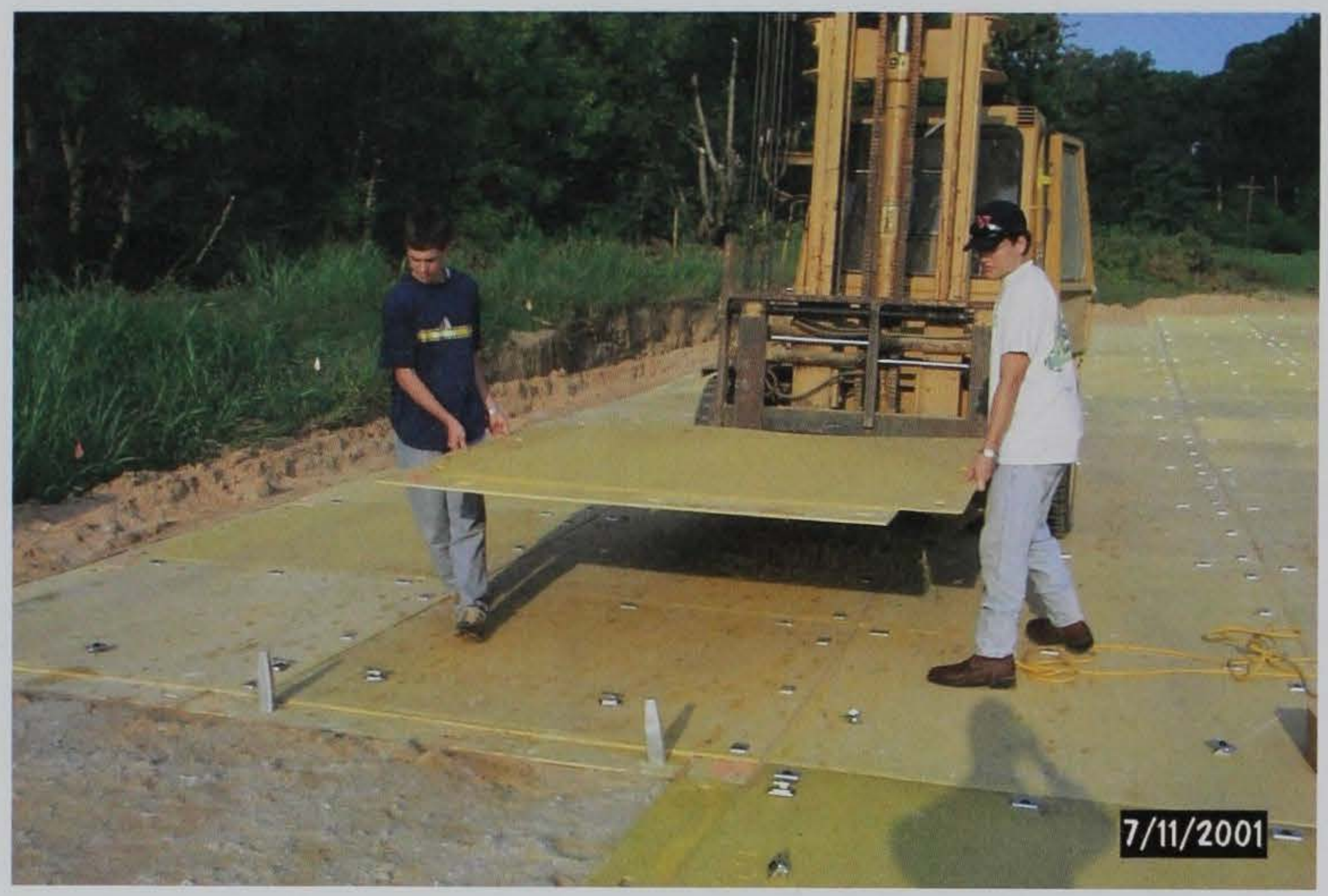

Photo 39. Two alignment tools positioned to guide new MP mat panel

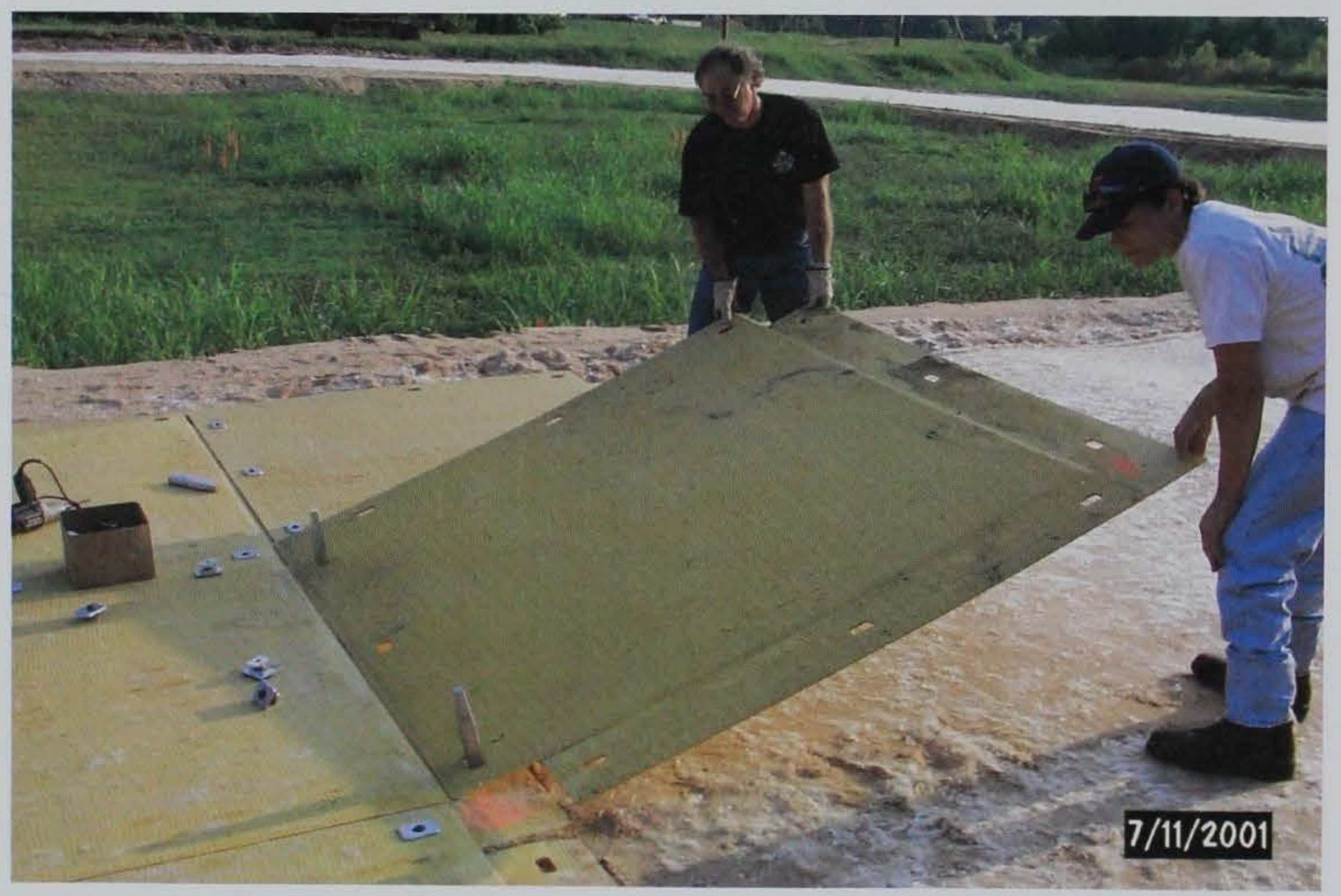

Photo 40. Using alignment tools to guide new panel into position 


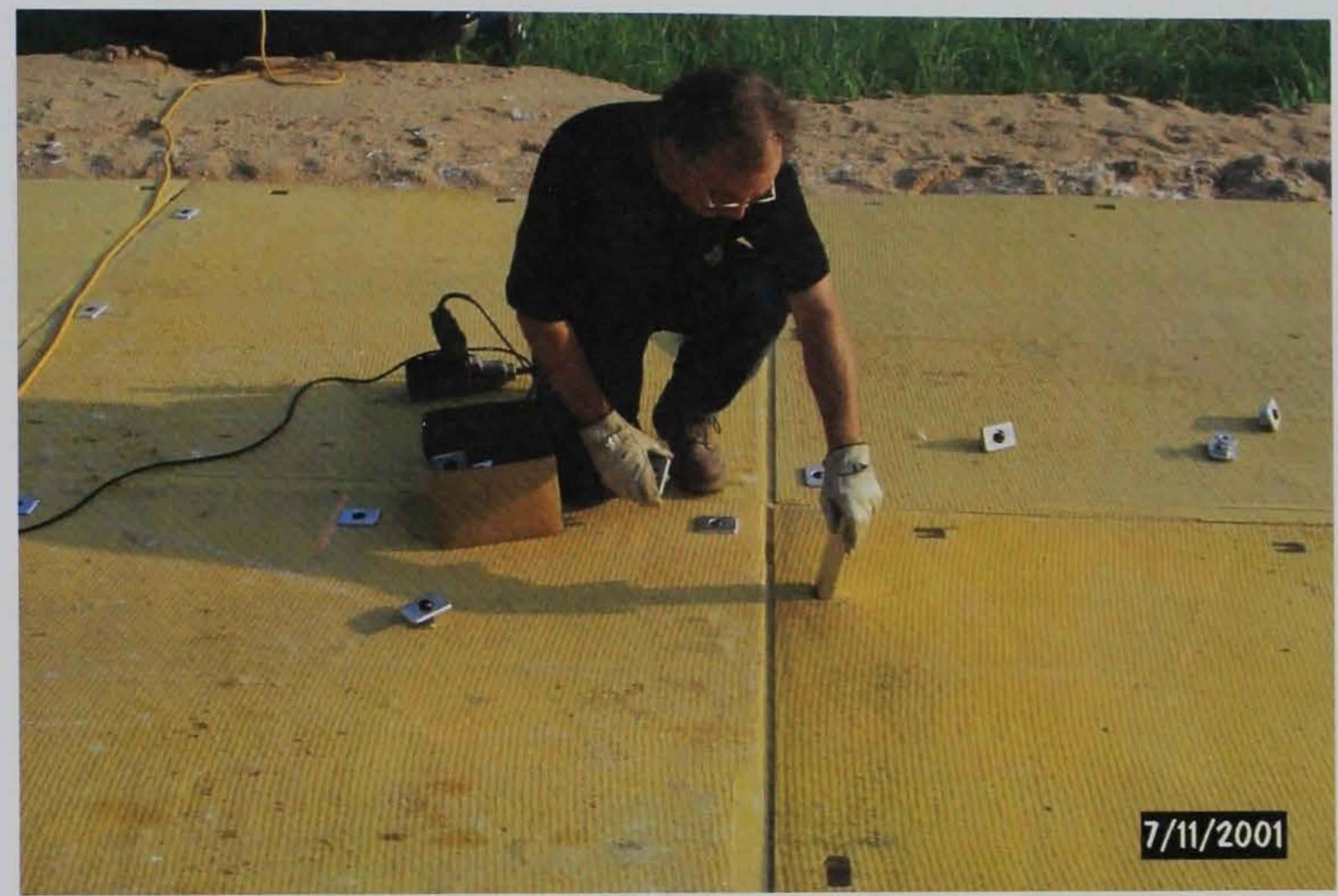

Photo 41. Aligning mat panel holes using alignment tool

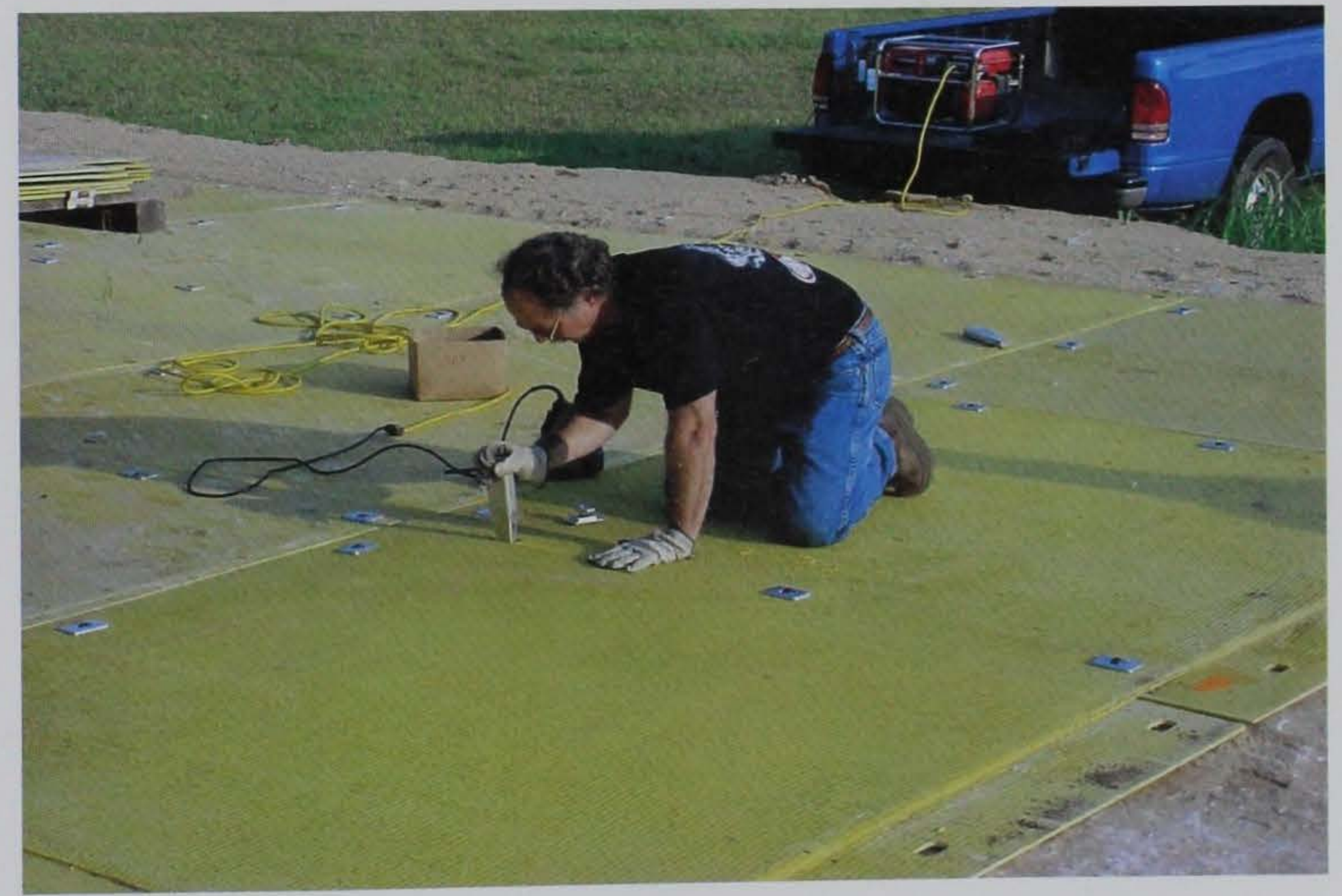

Photo 42. Aligning final set of mat holes on installed panel 


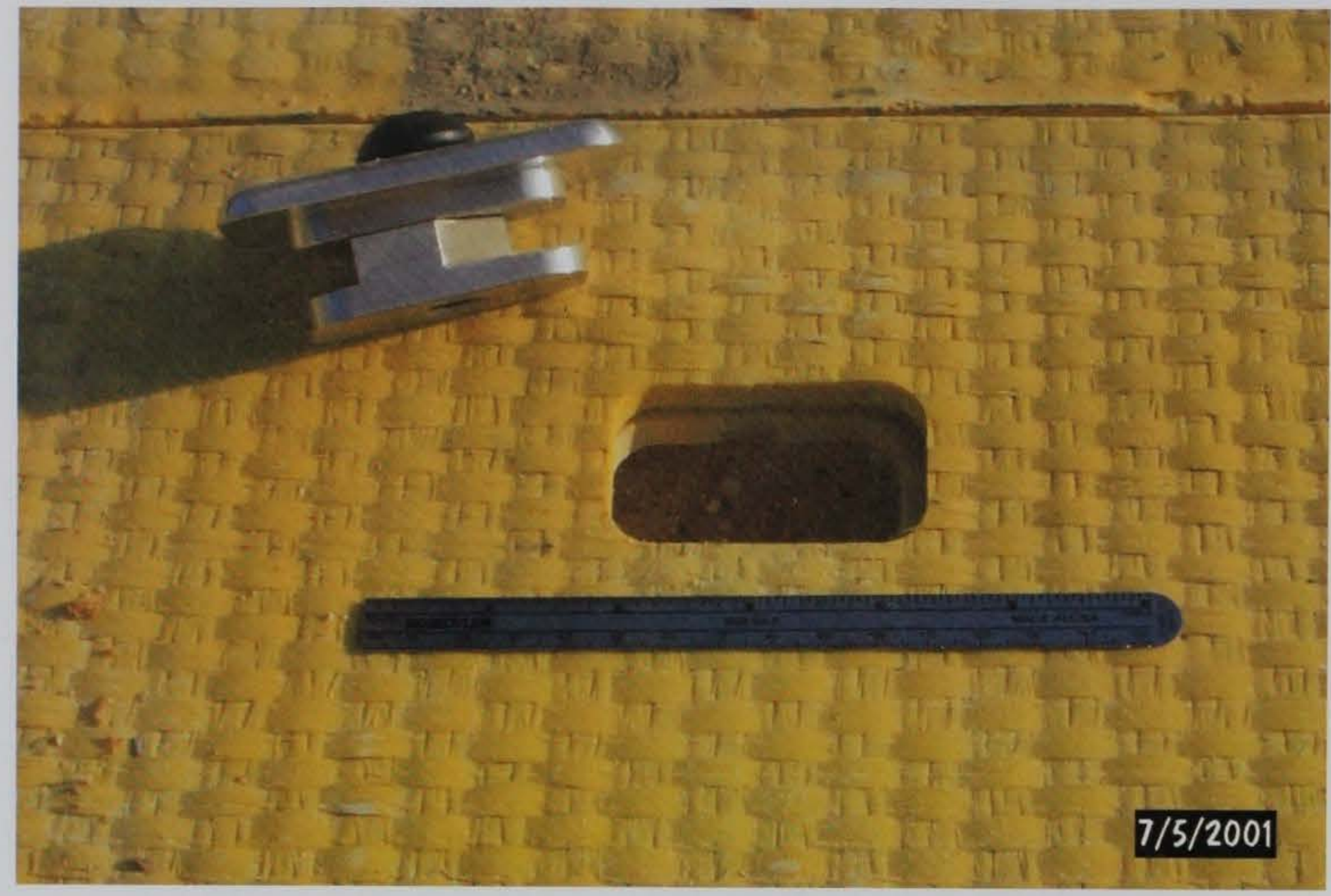

Photo 43. Close-up view of aligned holes ready for pin insertion

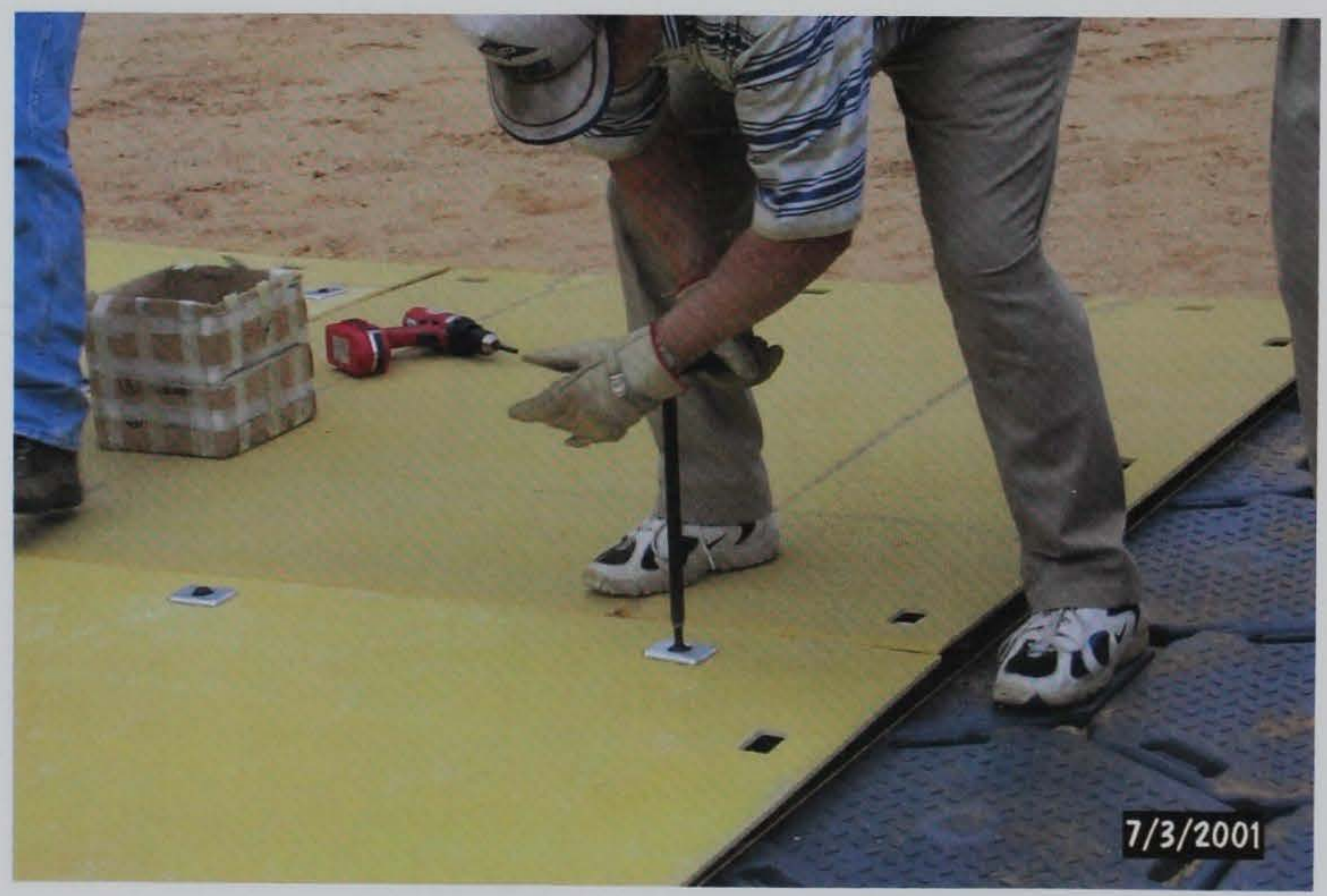

Photo 44. Connector pin pre-tightening using hand tool 


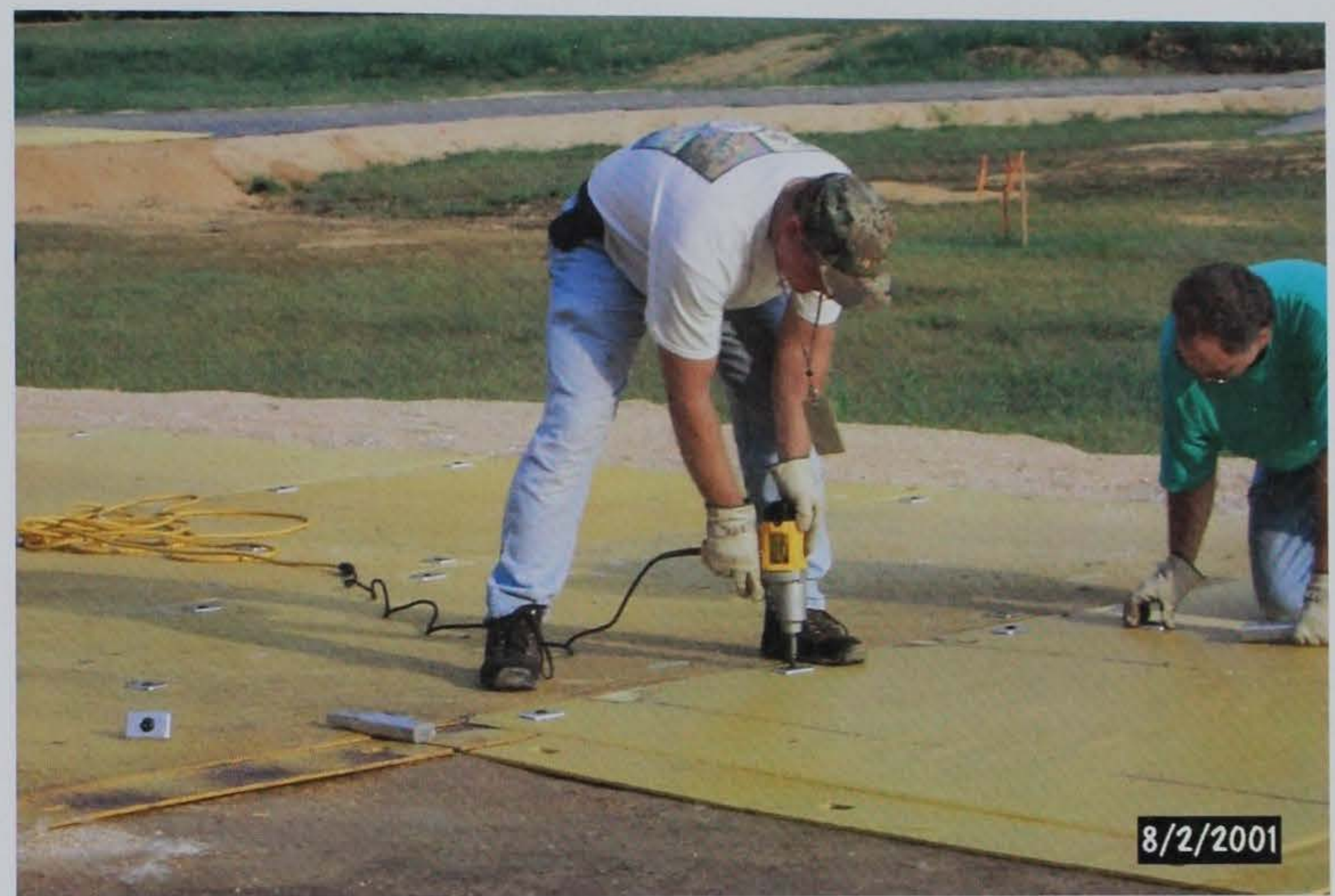

Photo 45. Final tightening of connector pins

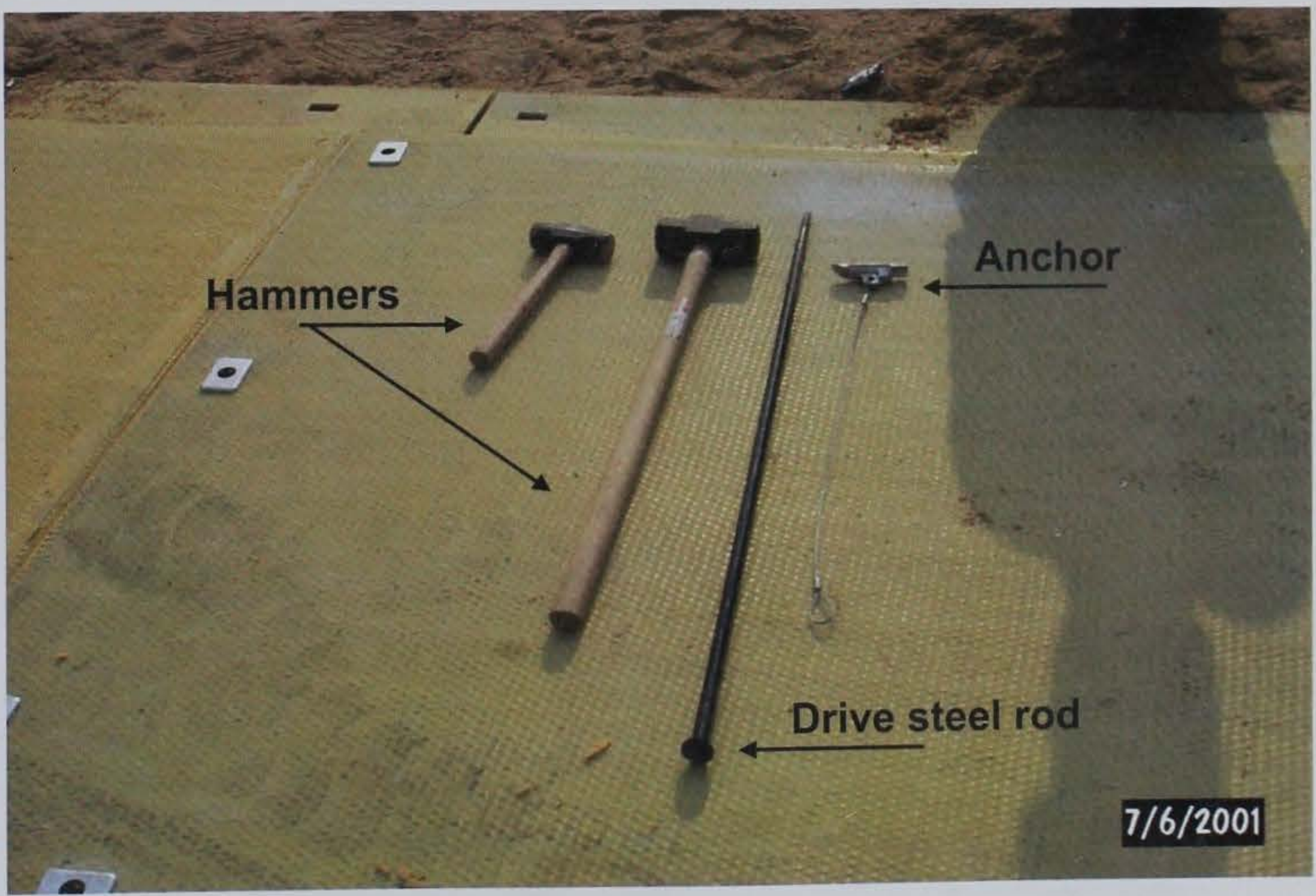

Photo 46. Duckbill anchor system 


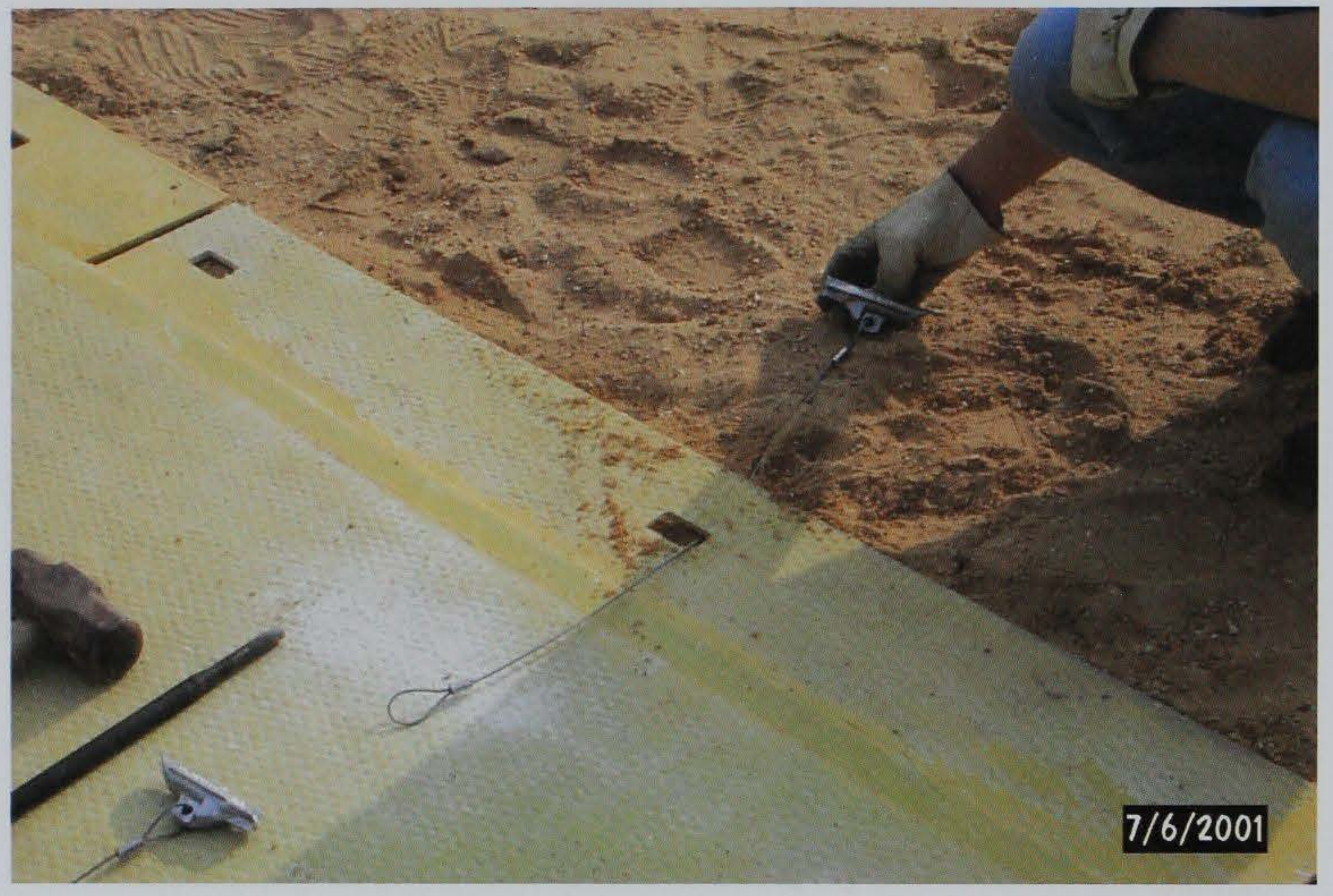

Photo 47. Anchor cable inserted throughout the mat hole

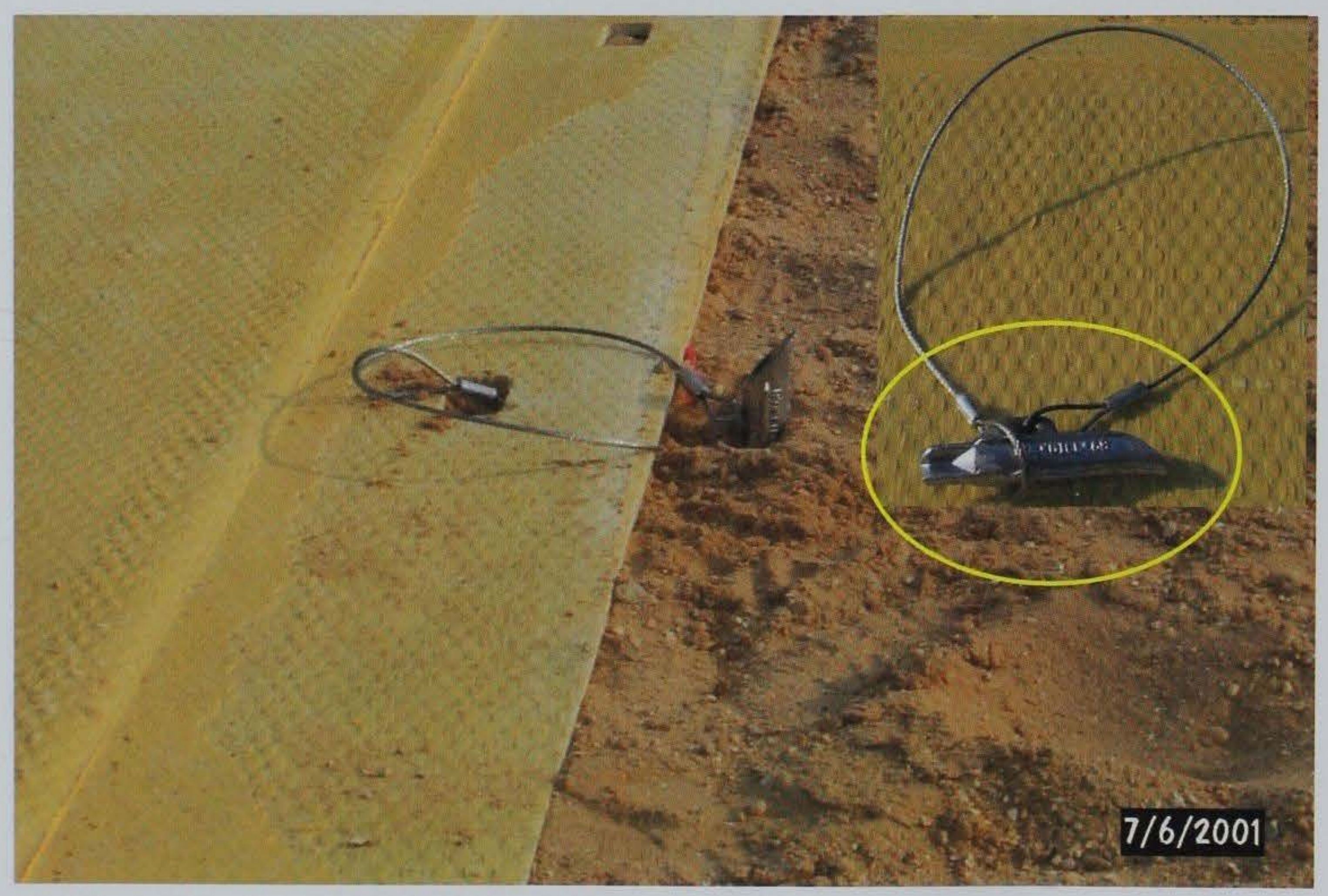

Photo 48. Anchor passed throughout the cable's eye 


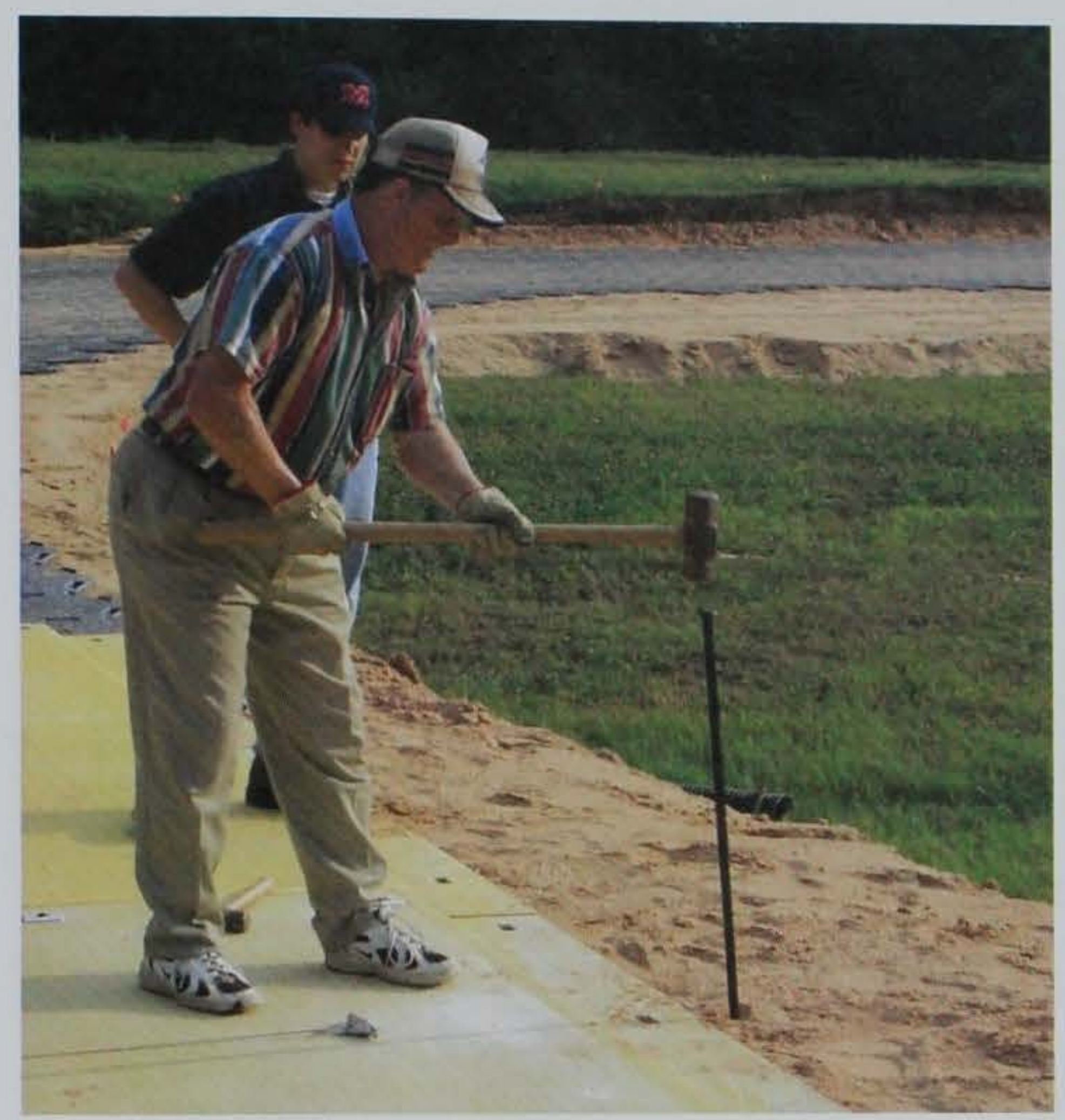

Photo 49. Driving the anchor using the steel driver rod

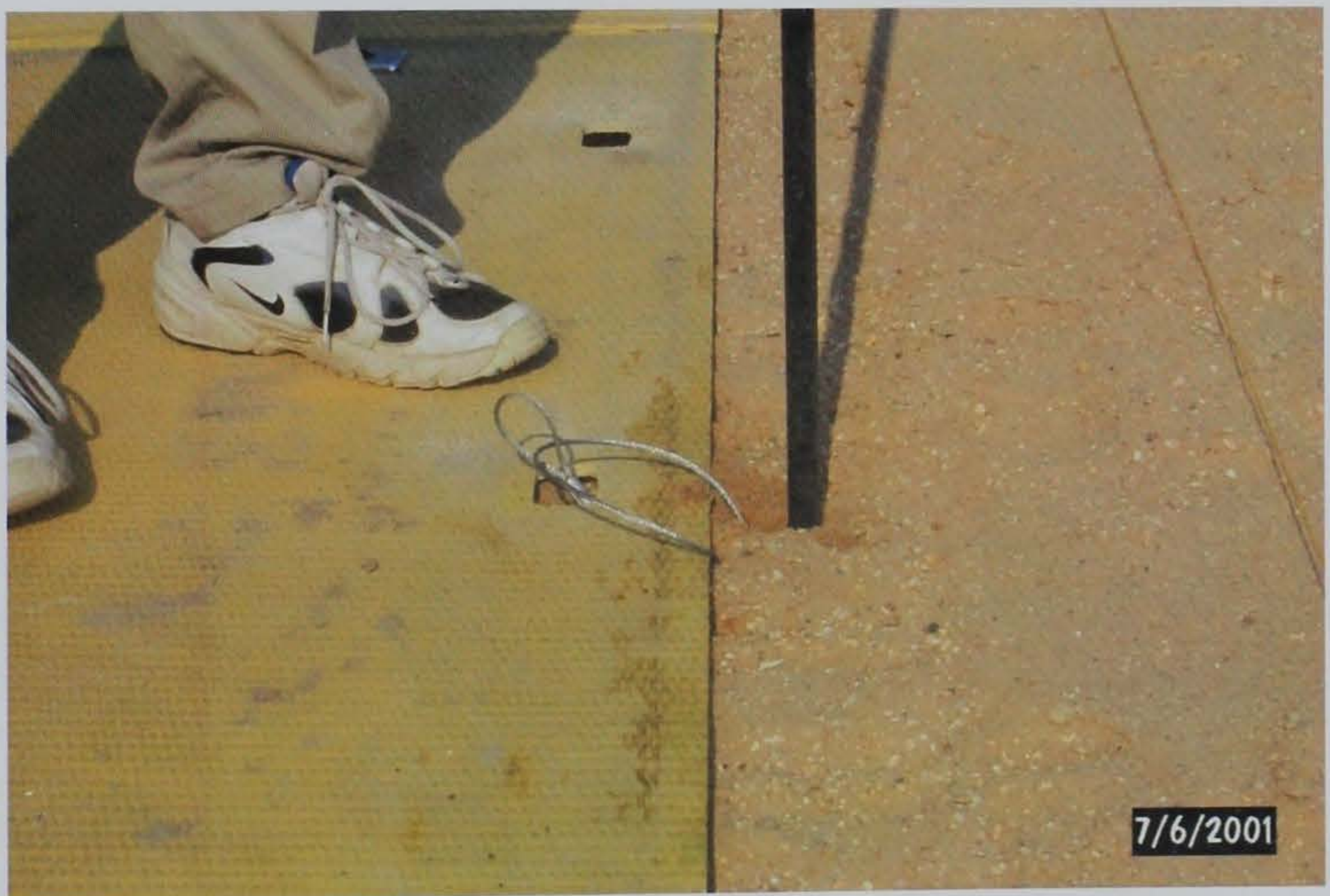

Photo 50. Close-up of the anchor driven into the ground 


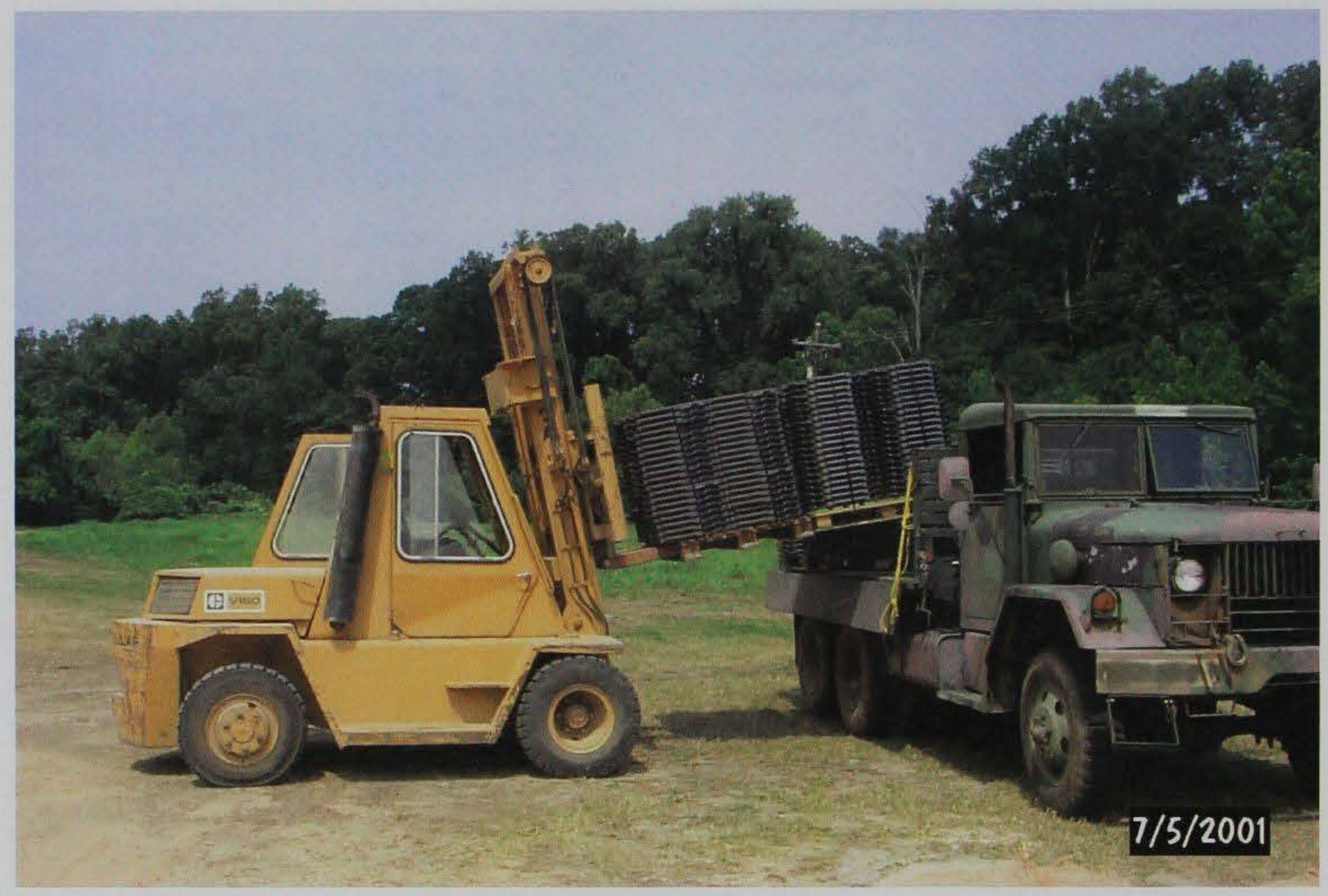

Photo 51. Hexagonal plastic mat on pallets

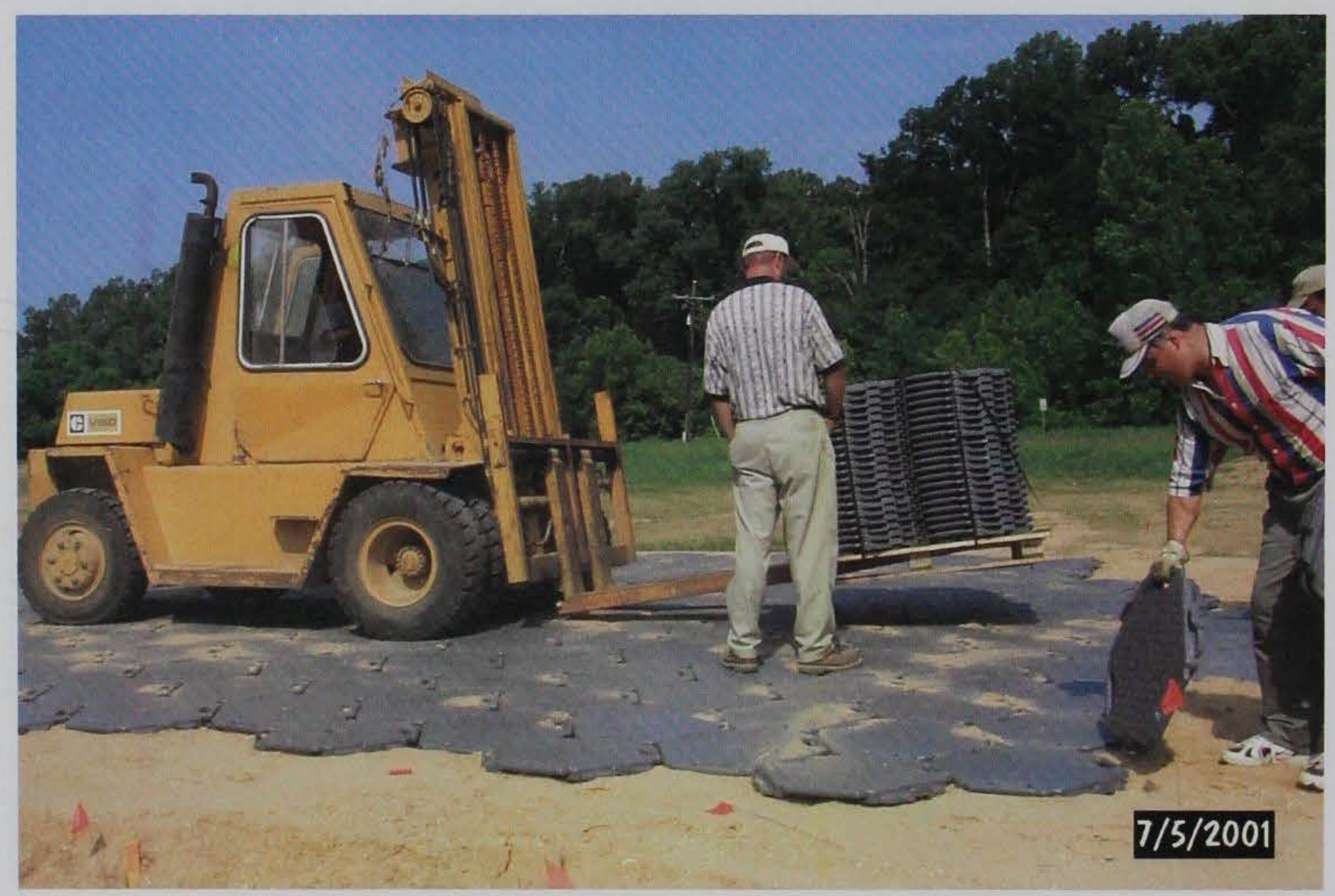

Photo 52. Forklift delivering Allround hexagonal mats to installation site 


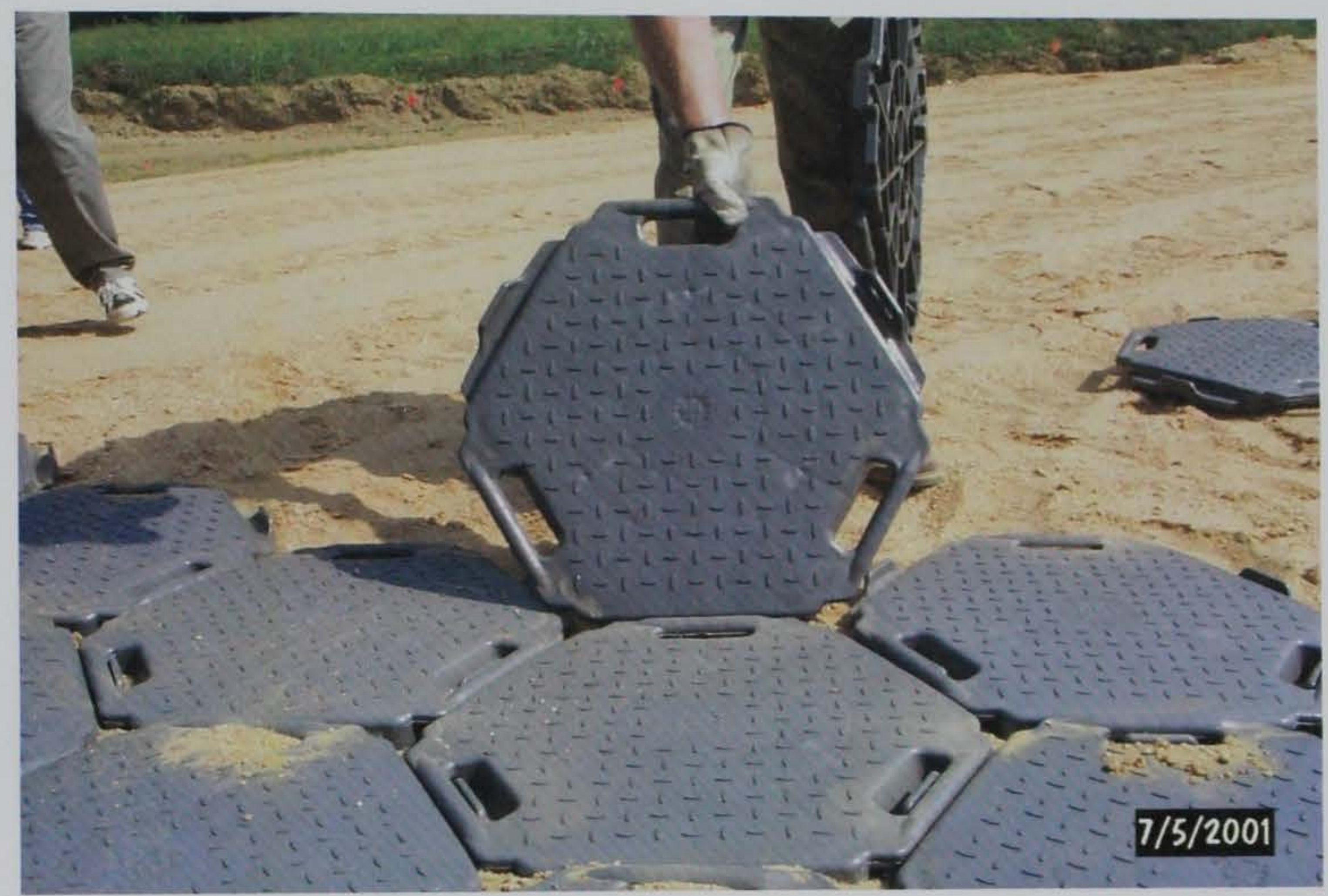

Photo 53. Allround hexagonal plastic installation - Step 1

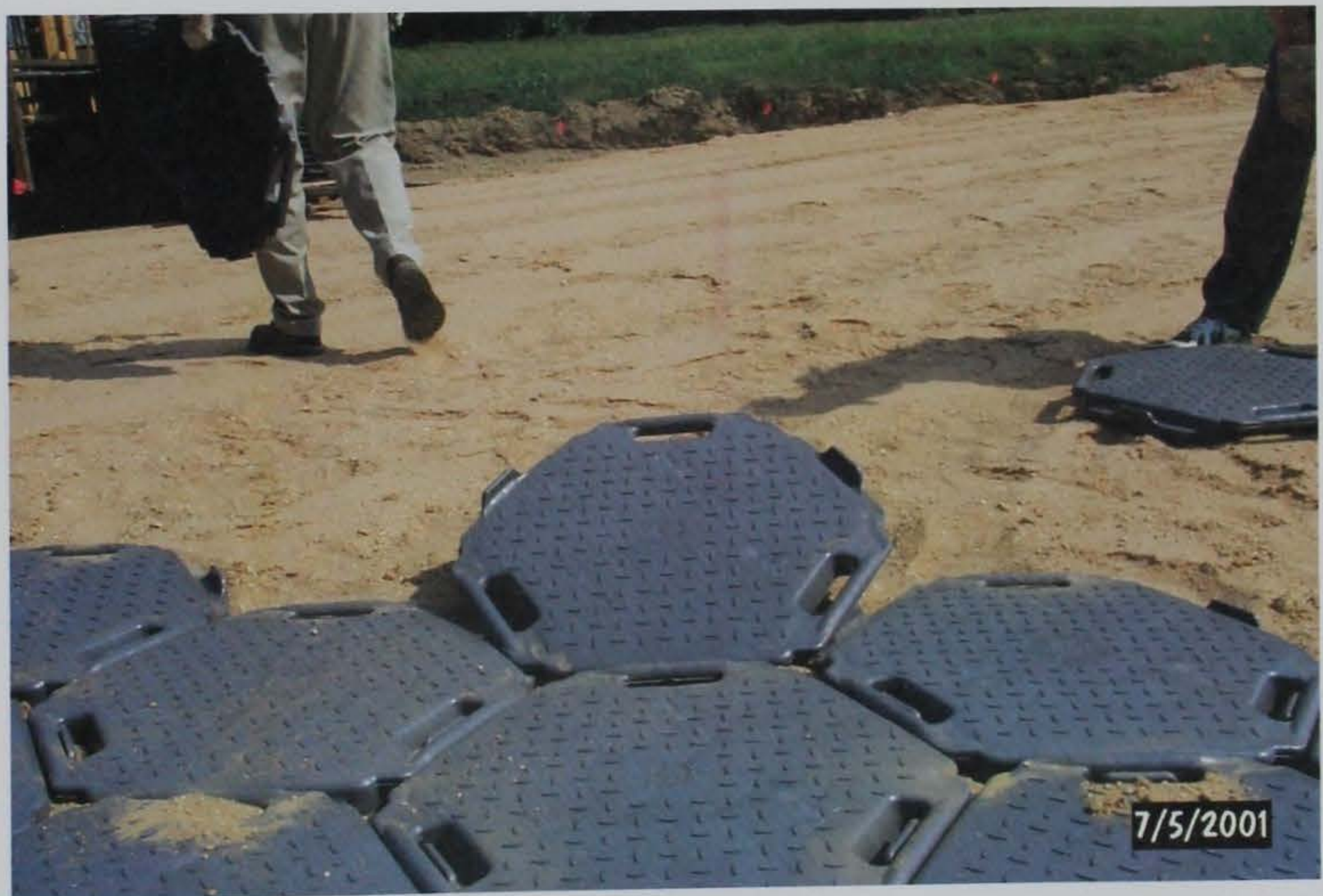

Photo 54. Allround hexagonal mats installation - Step 2 


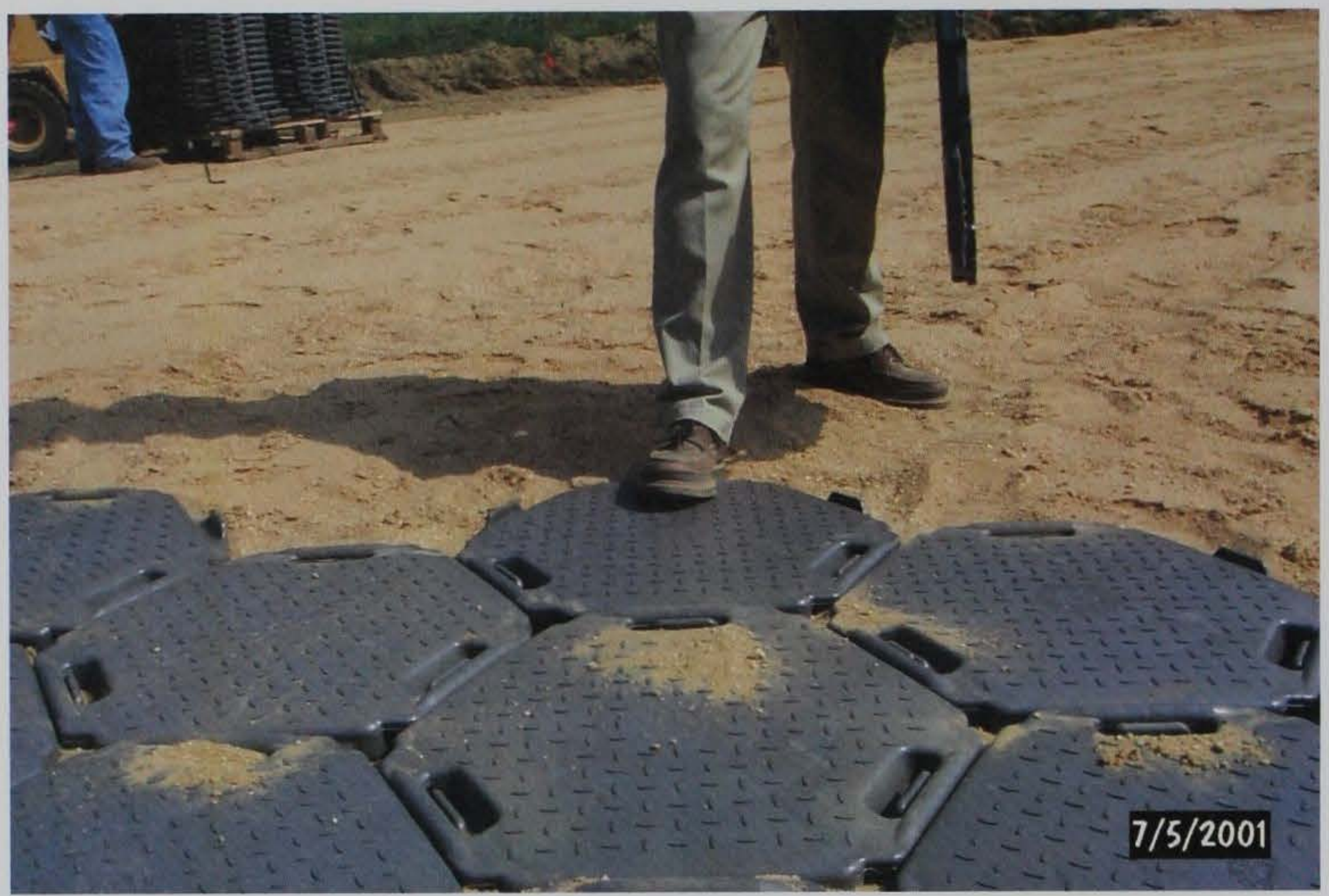

Photo 55. Allround hexagonal plastic mat installation - Step 3

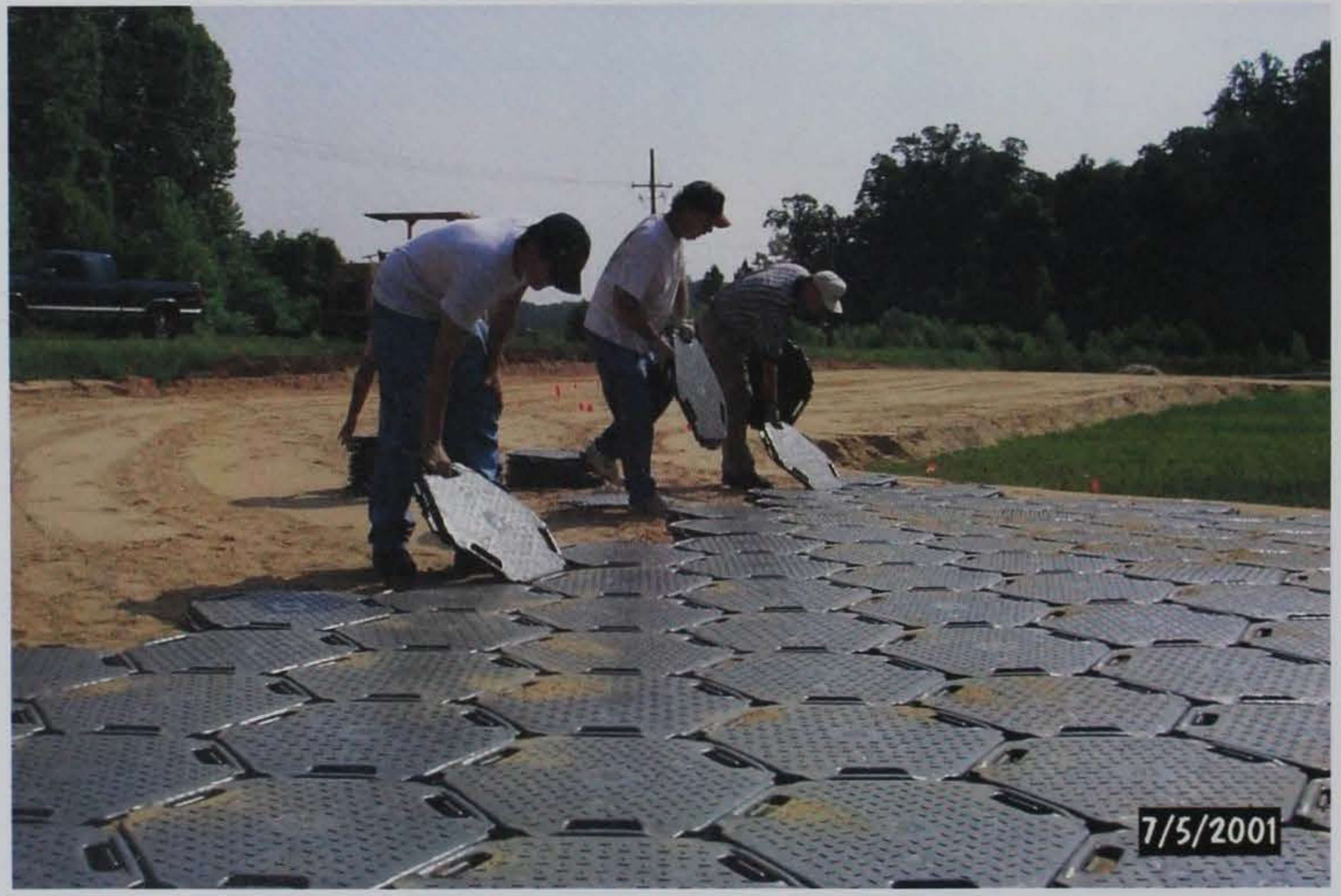

Photo 56. Allround hexagonal mats installation progress 


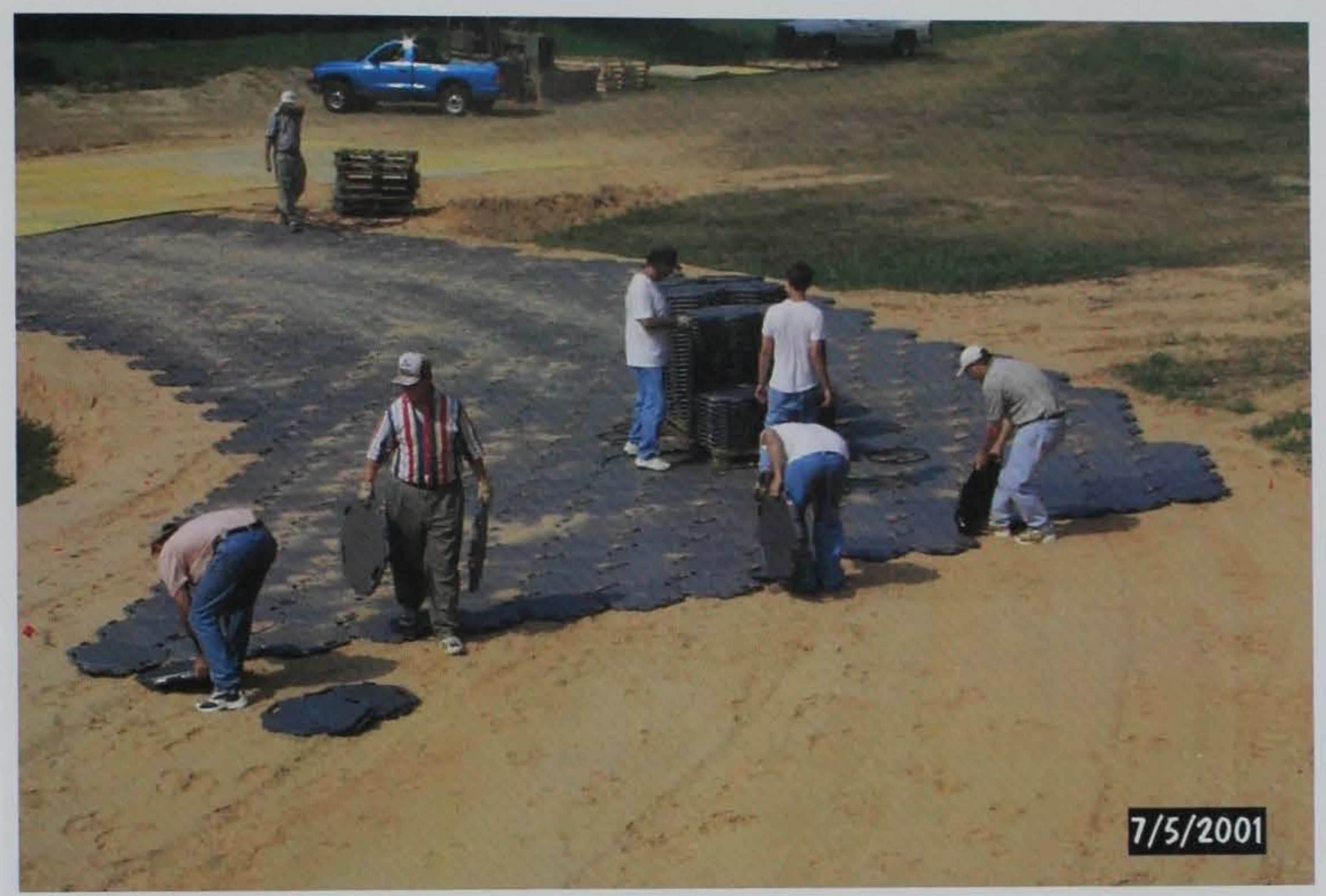

Photo 57. Overview of Allround hexagonal plastic mat section

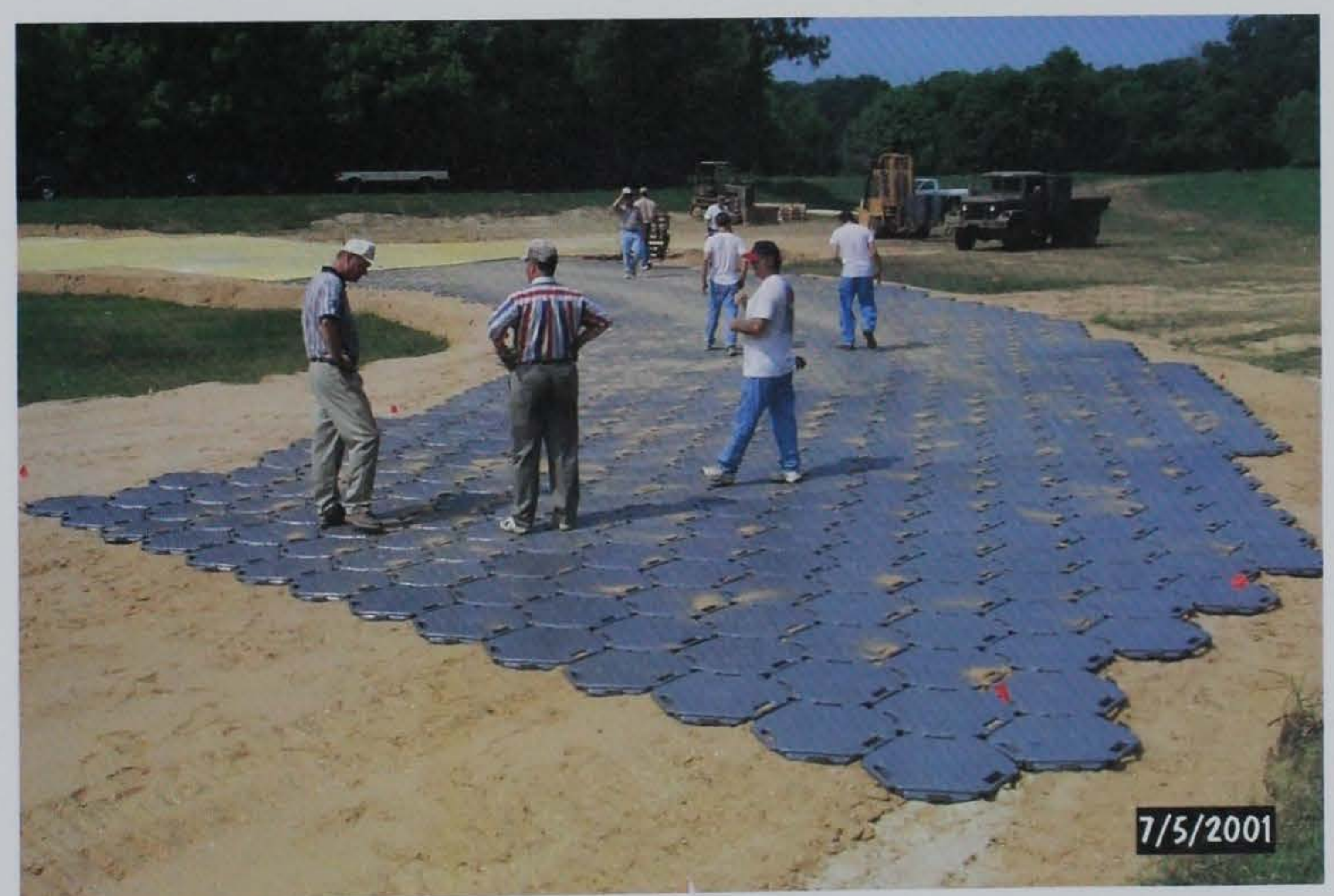

Photo 58. Completion of Allround hexagonal mat section 




Photo 59. Special hexagonal plastic mat installation - Step 1

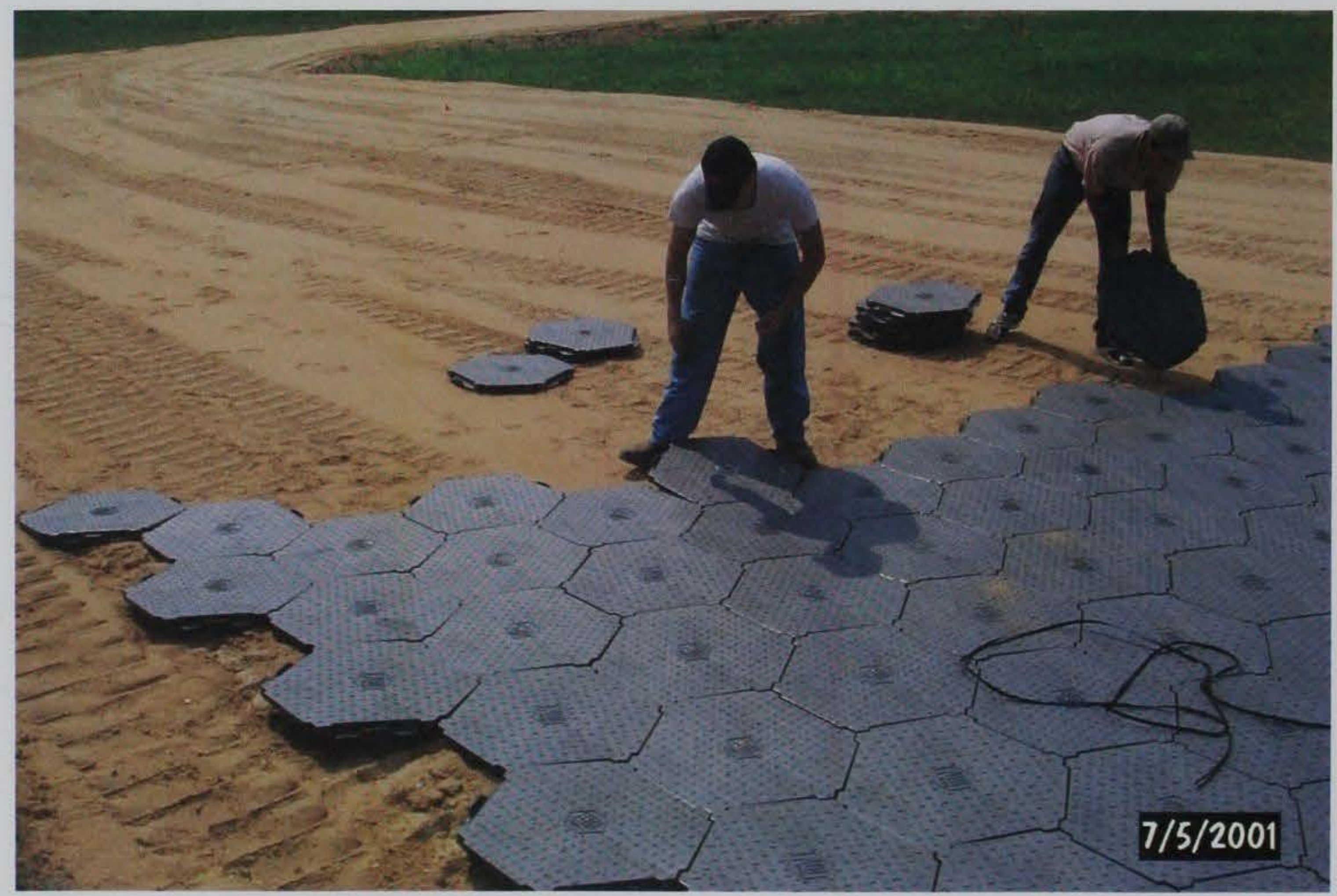

Photo 60 . Special hexagonal plastic mat - Step 2 and 3 

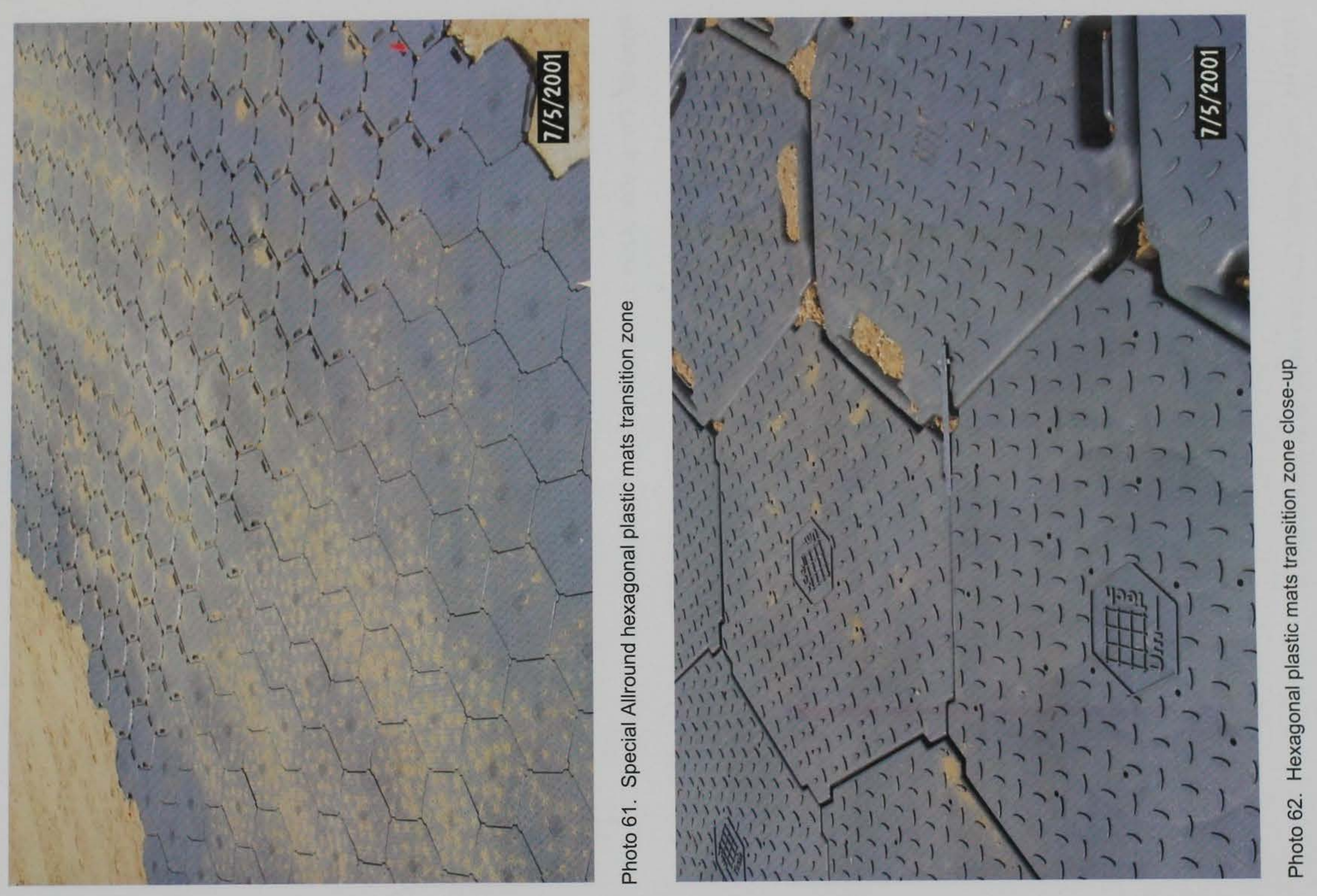


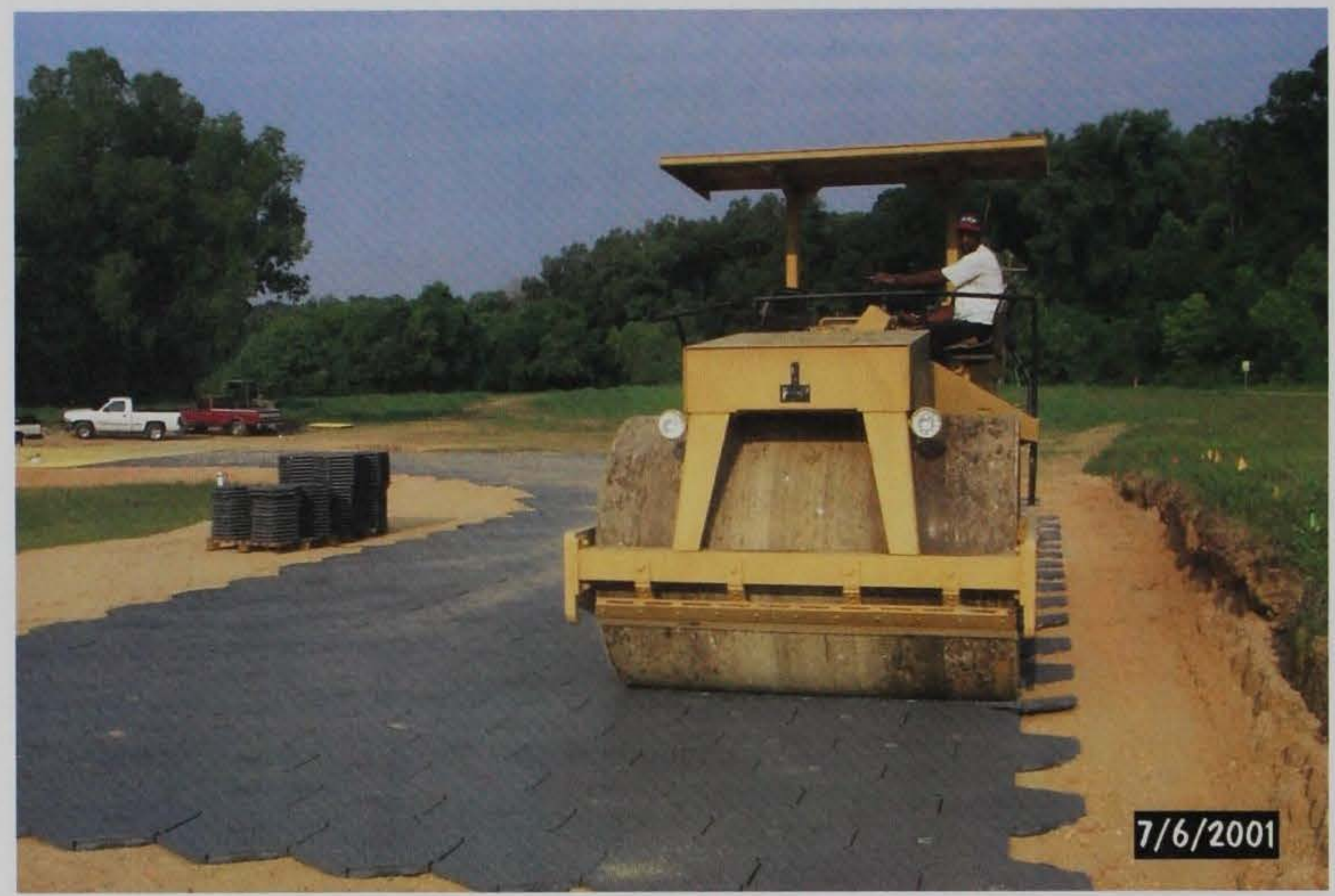

Photo 63. Compaction of Item 2 - Hexagonal plastic mat sections

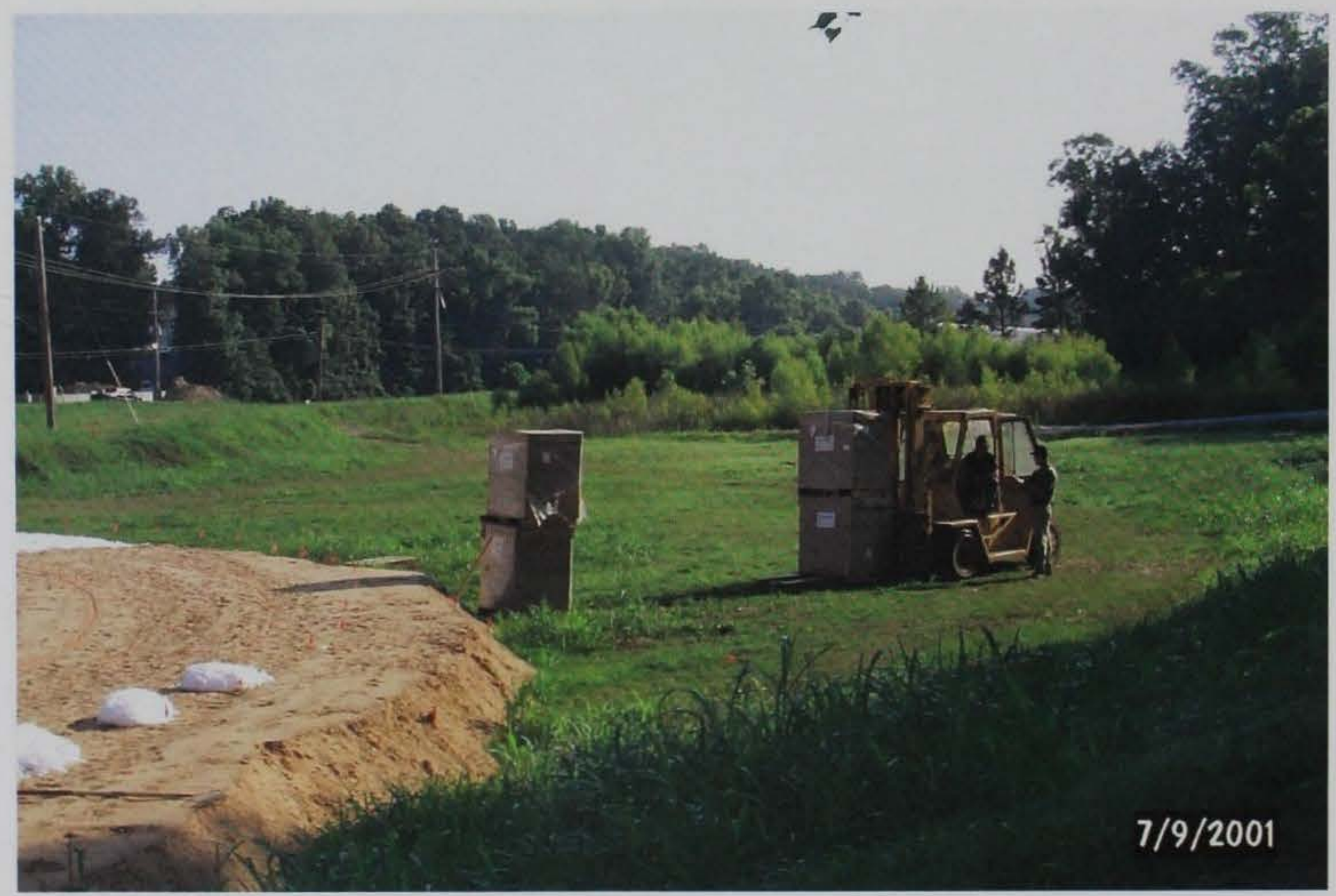

Photo 64 . 300-lb boxes of geofibers delivered to construction site 


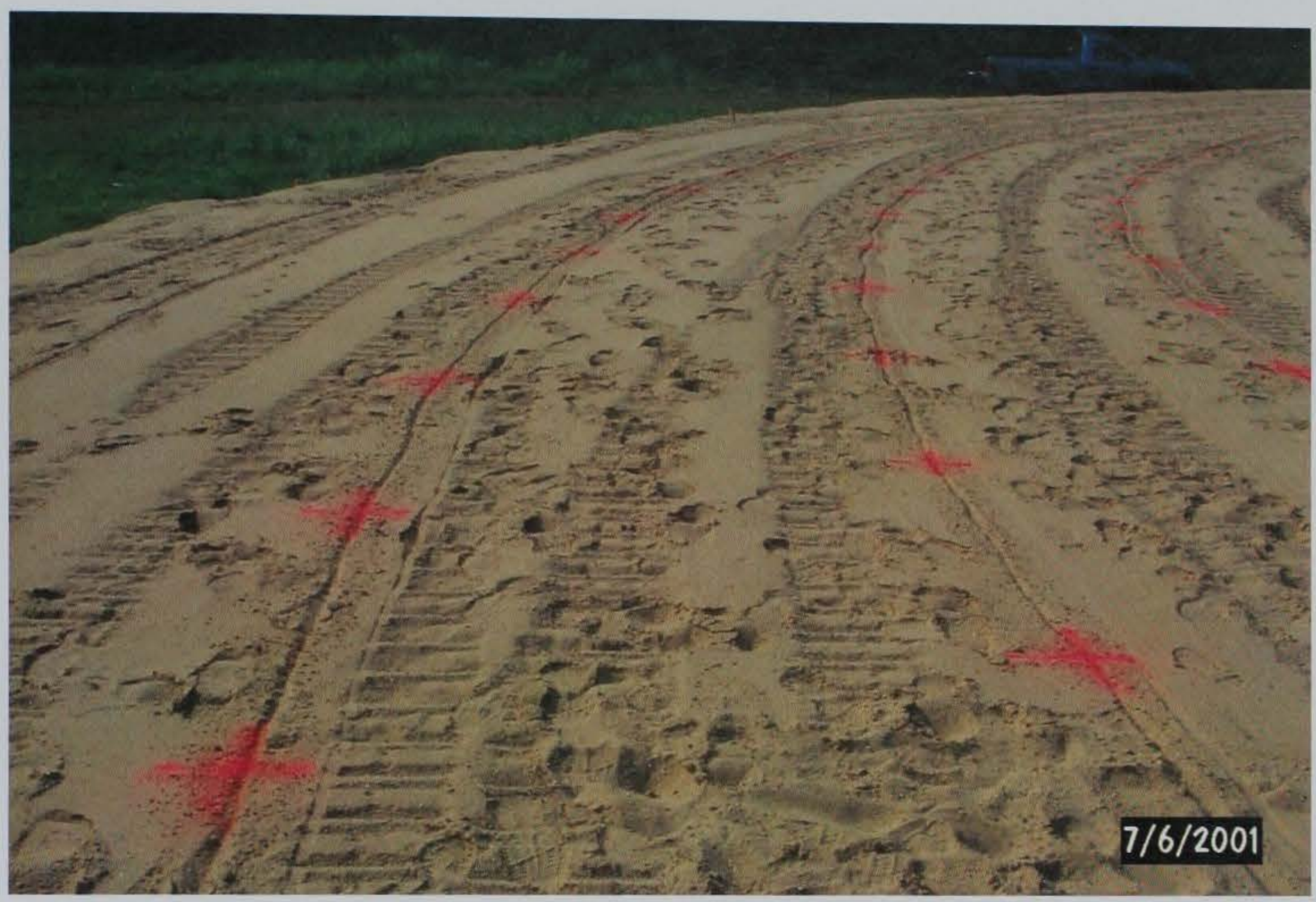

Photo 65. Longitudinal marking for geofiber bag placement

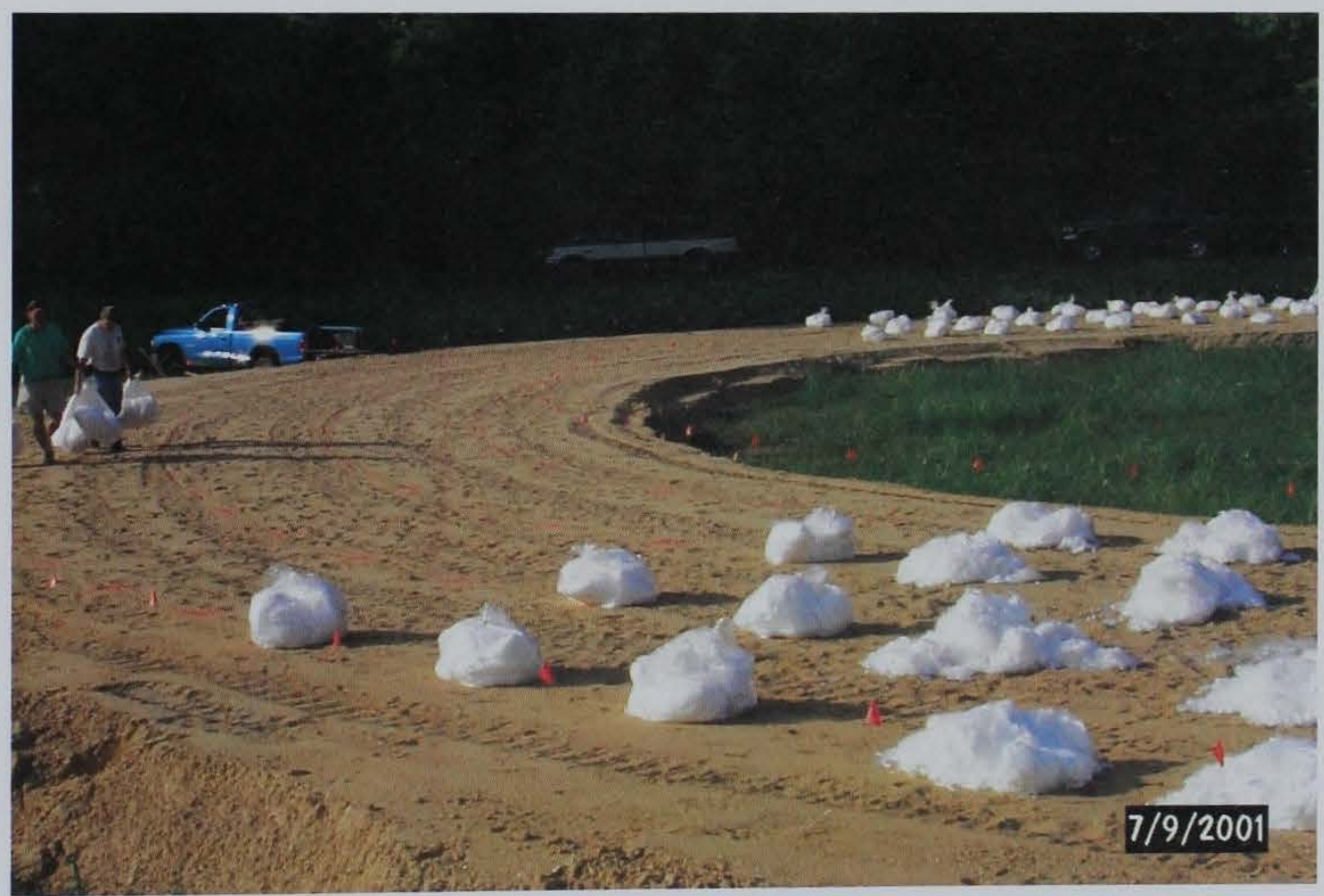

Photo 66. Geofiber bag placement 


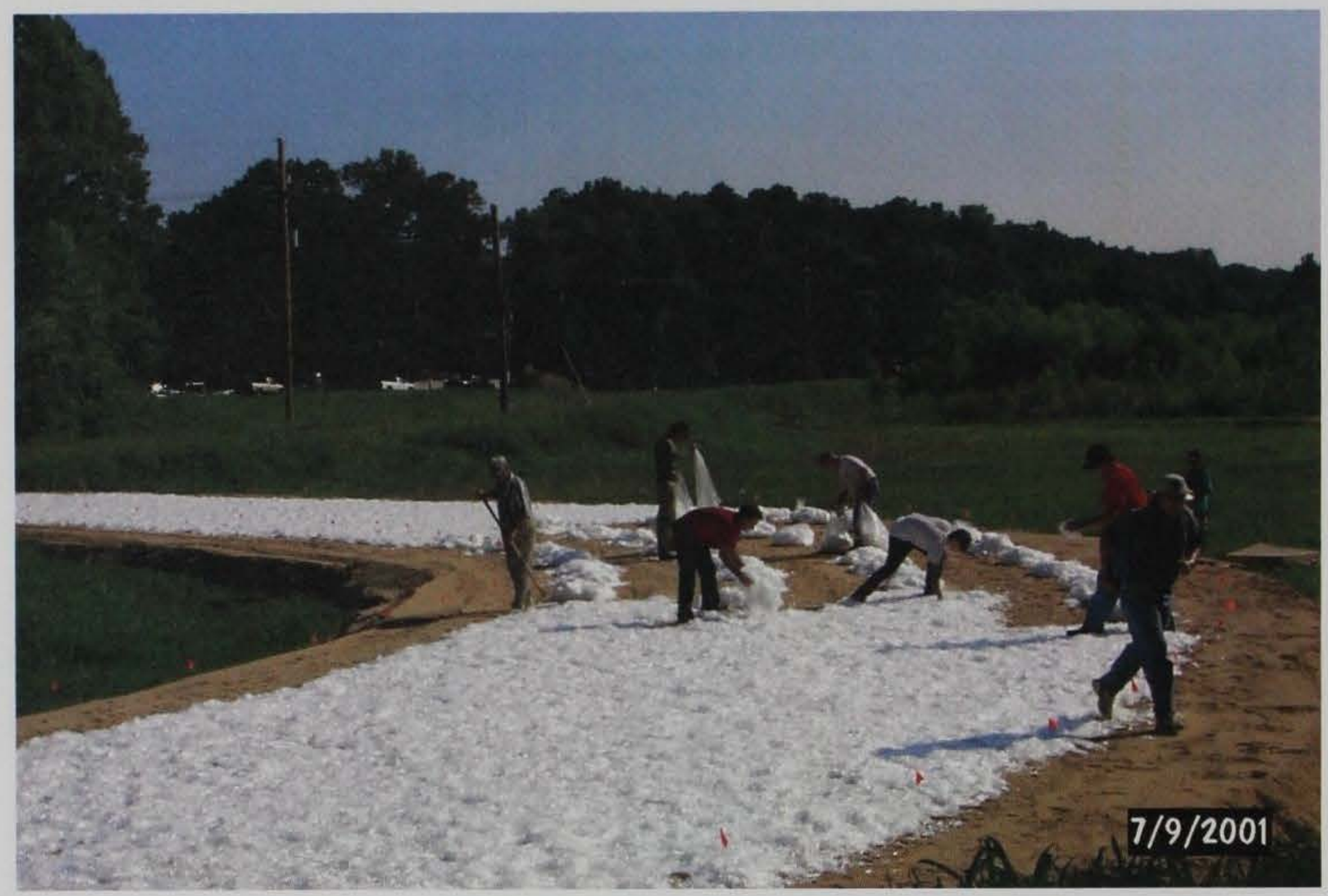

Photo 67. Spreading geofibers over the sand layer

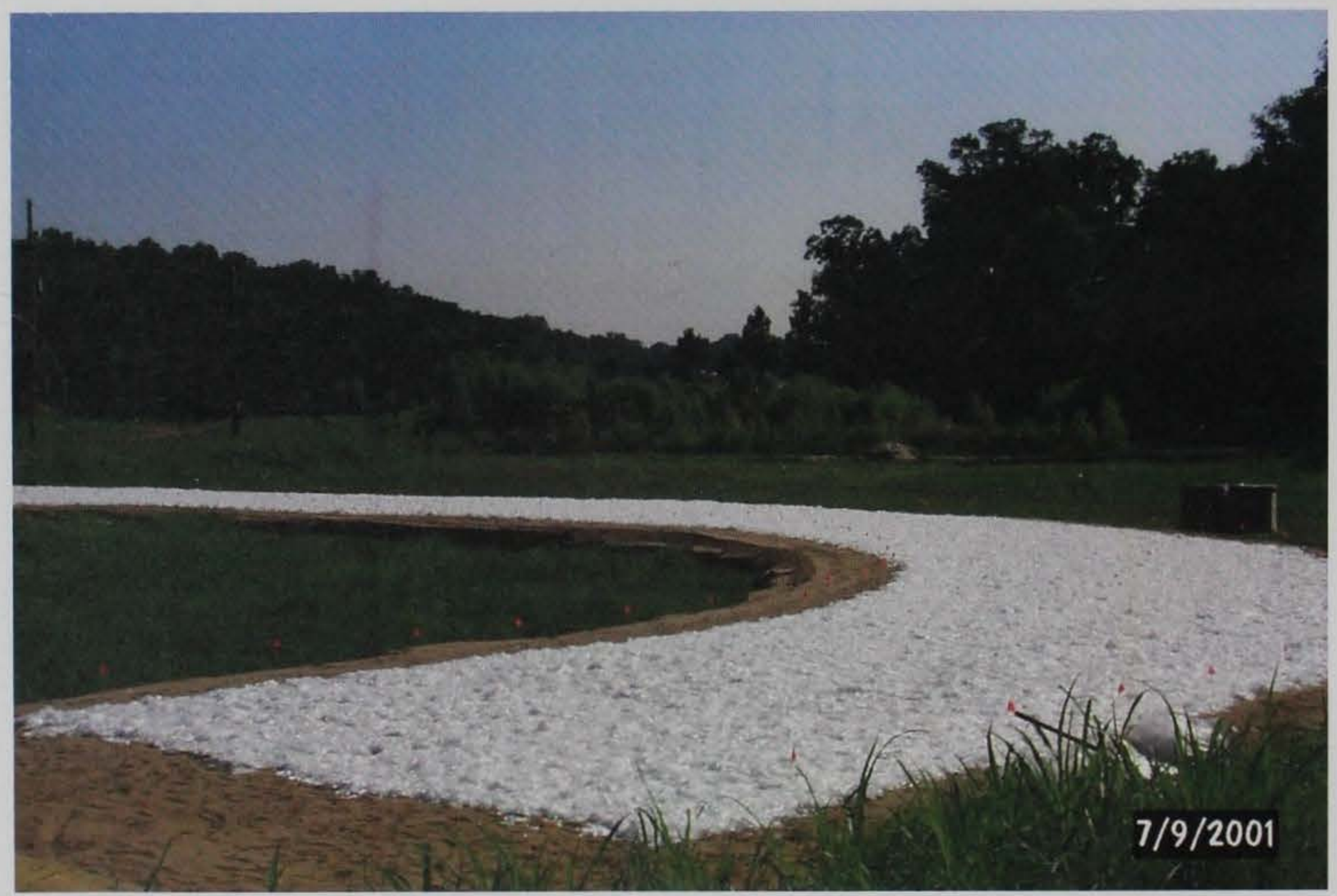

Photo 68 . Item 3 after spreading the geofiber and prior mixing 


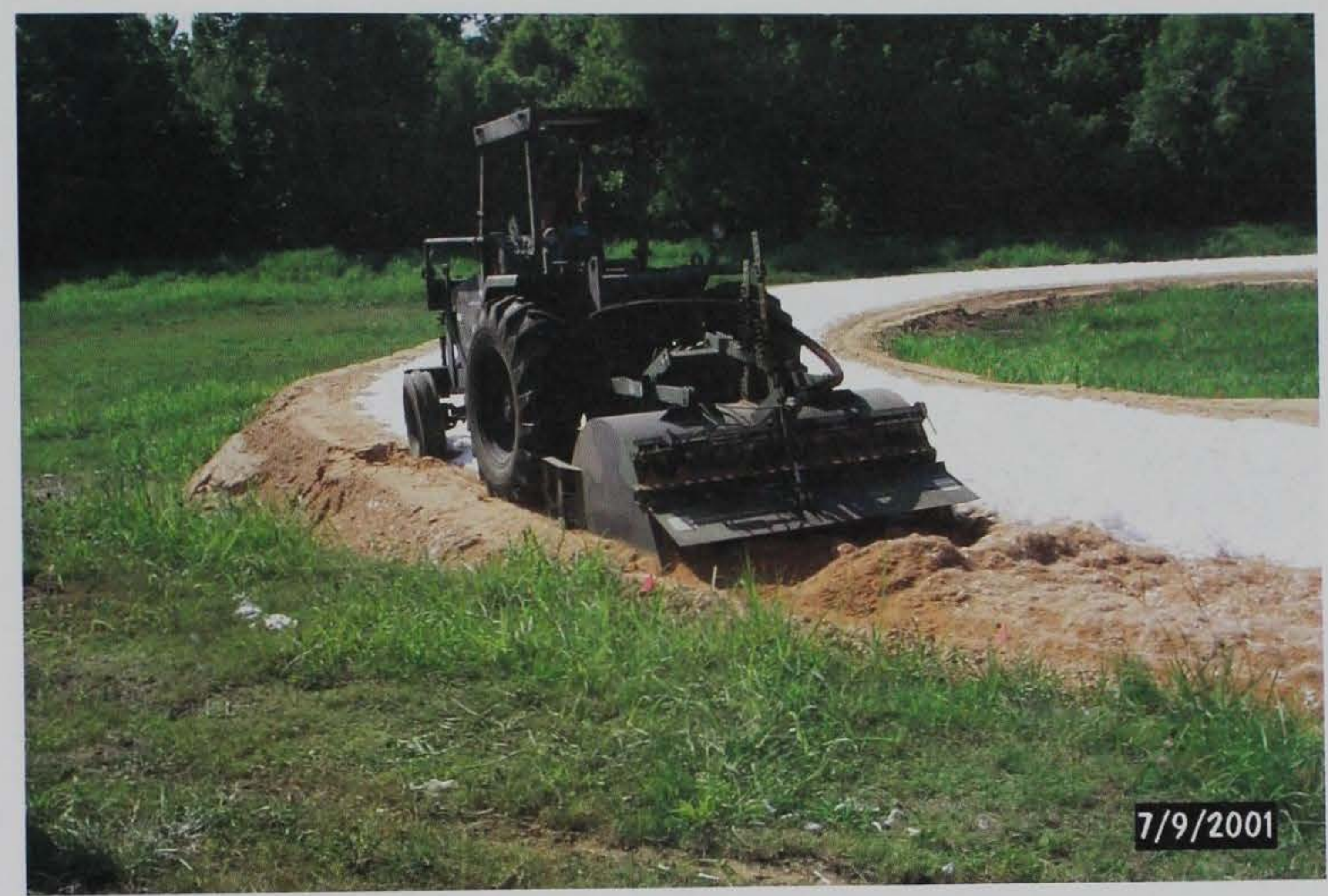

Photo 69. Mixing geofibers into the sand with self-propelled rotary mixer

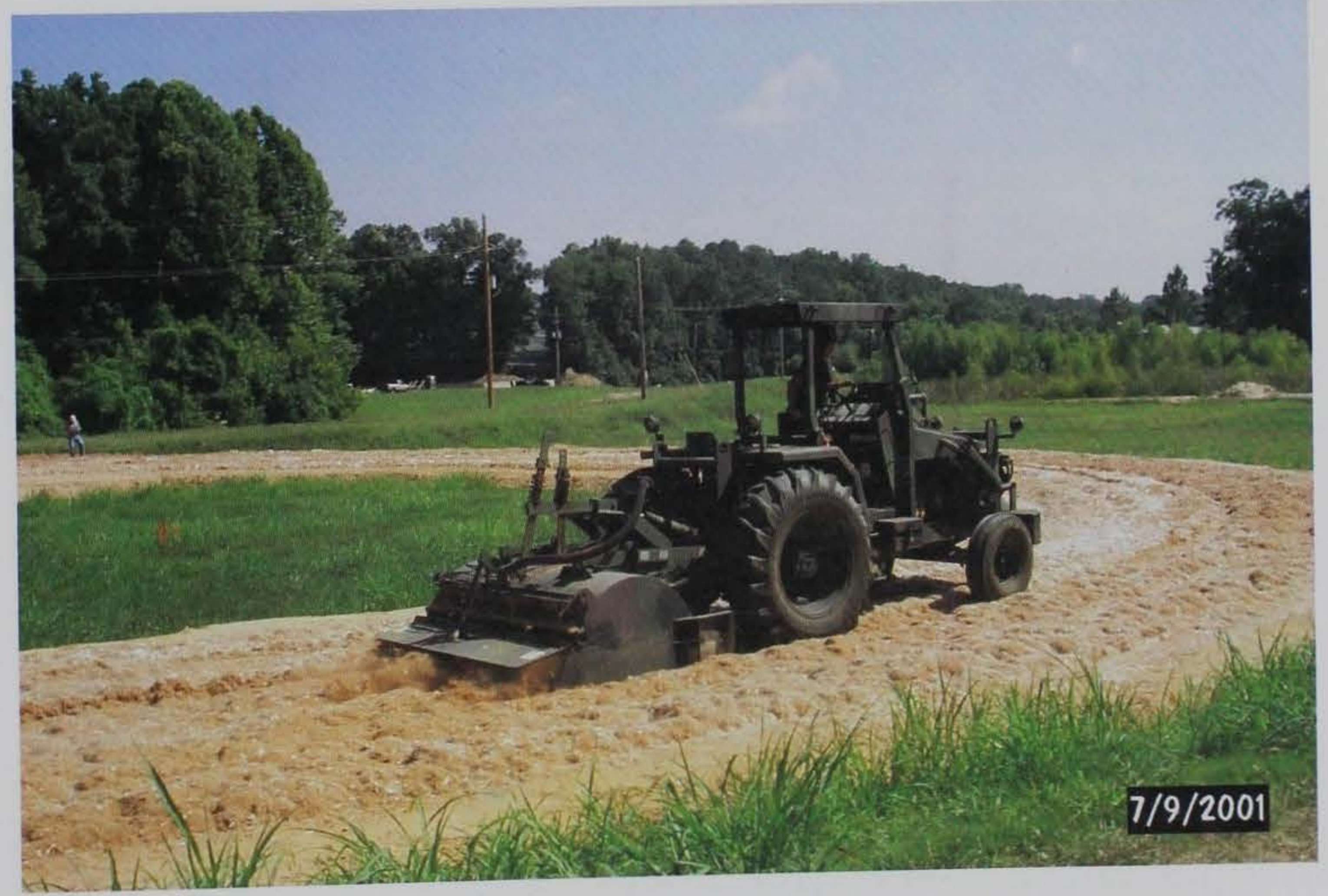

Photo 70 . Sand-geofiber item after 4 passes of the rotary mixer 


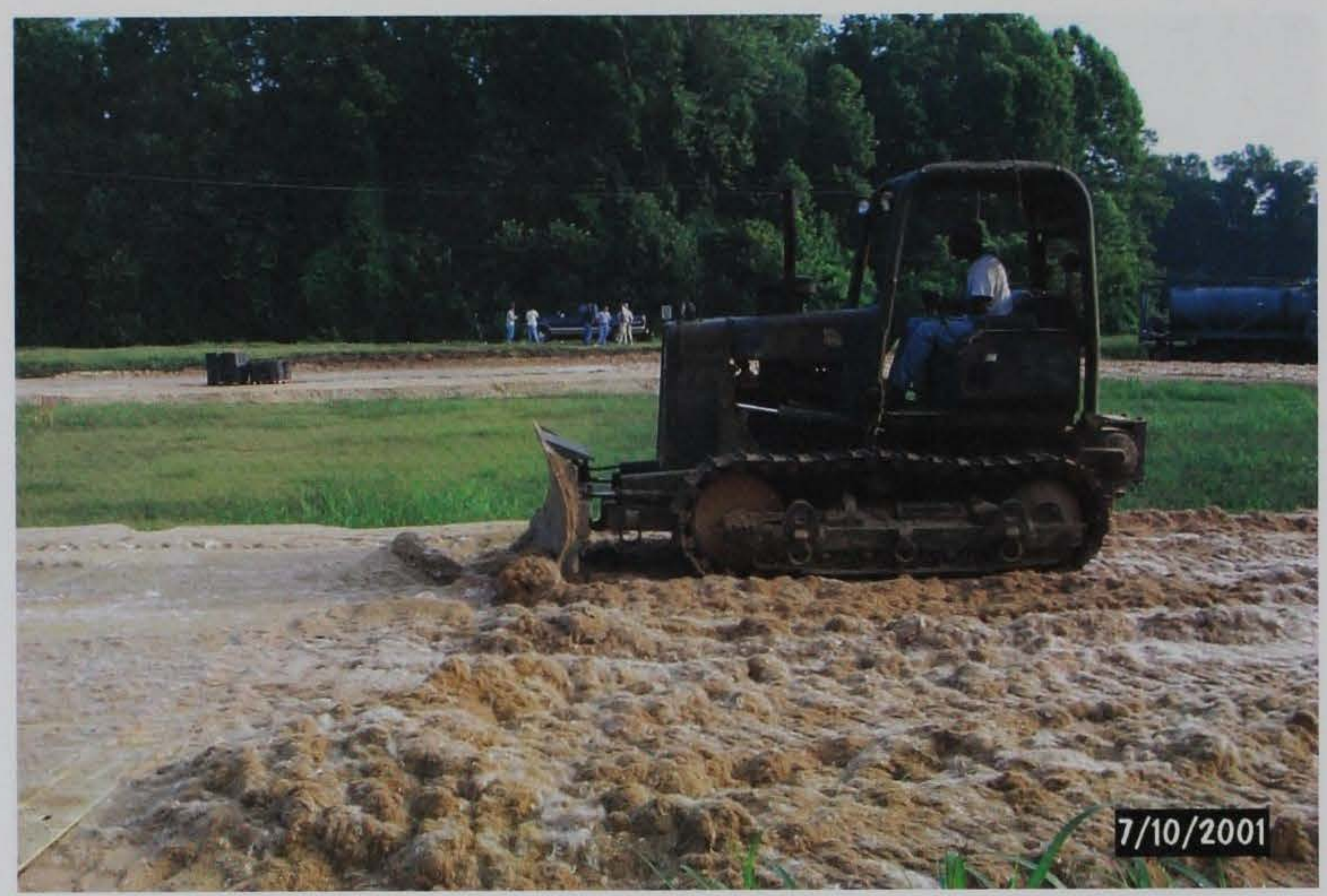

Photo 71. D4 dozer leveling/smoothing the sand-geofiber sections

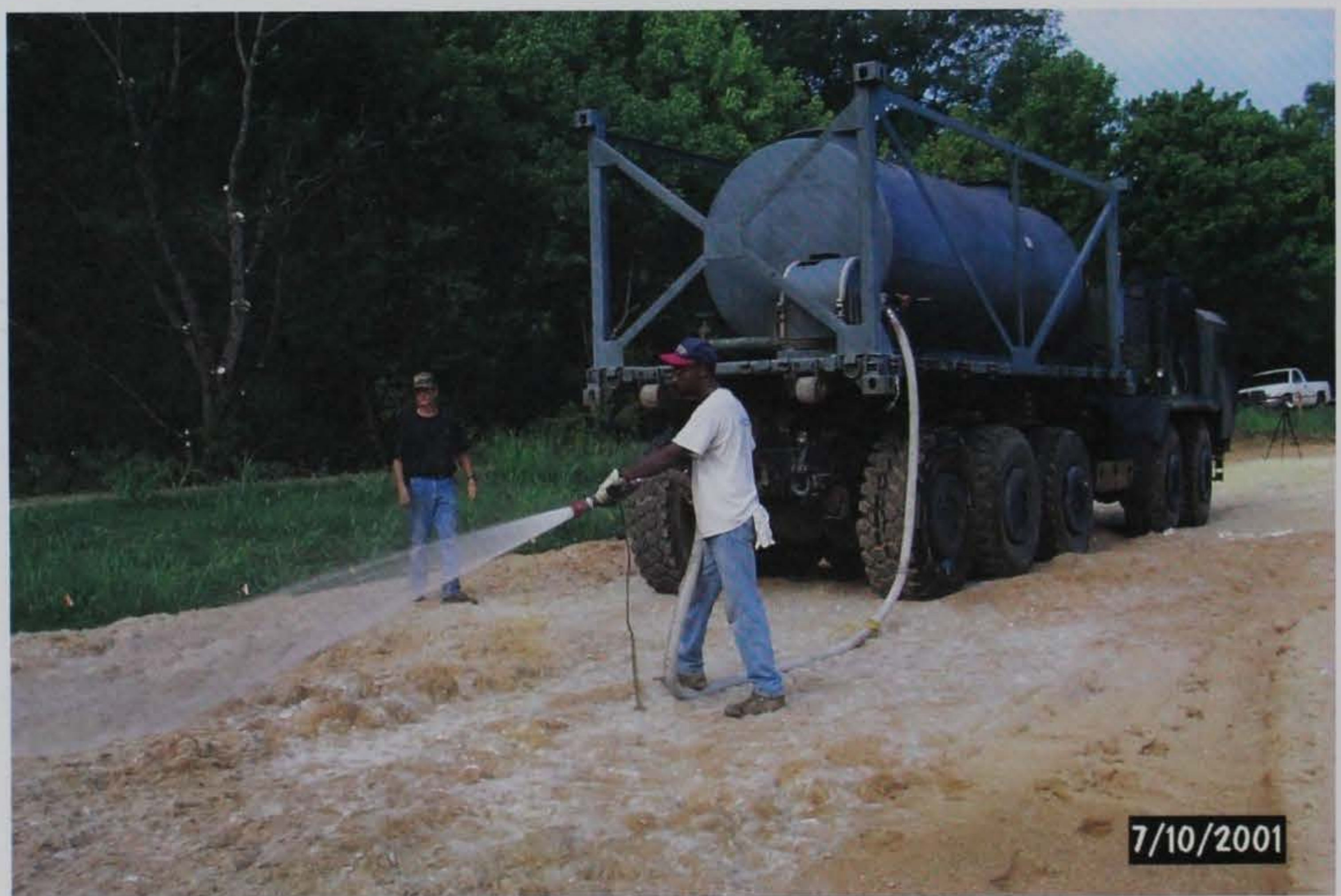

Photo 72. Watering sand-geofiber item prior compaction 


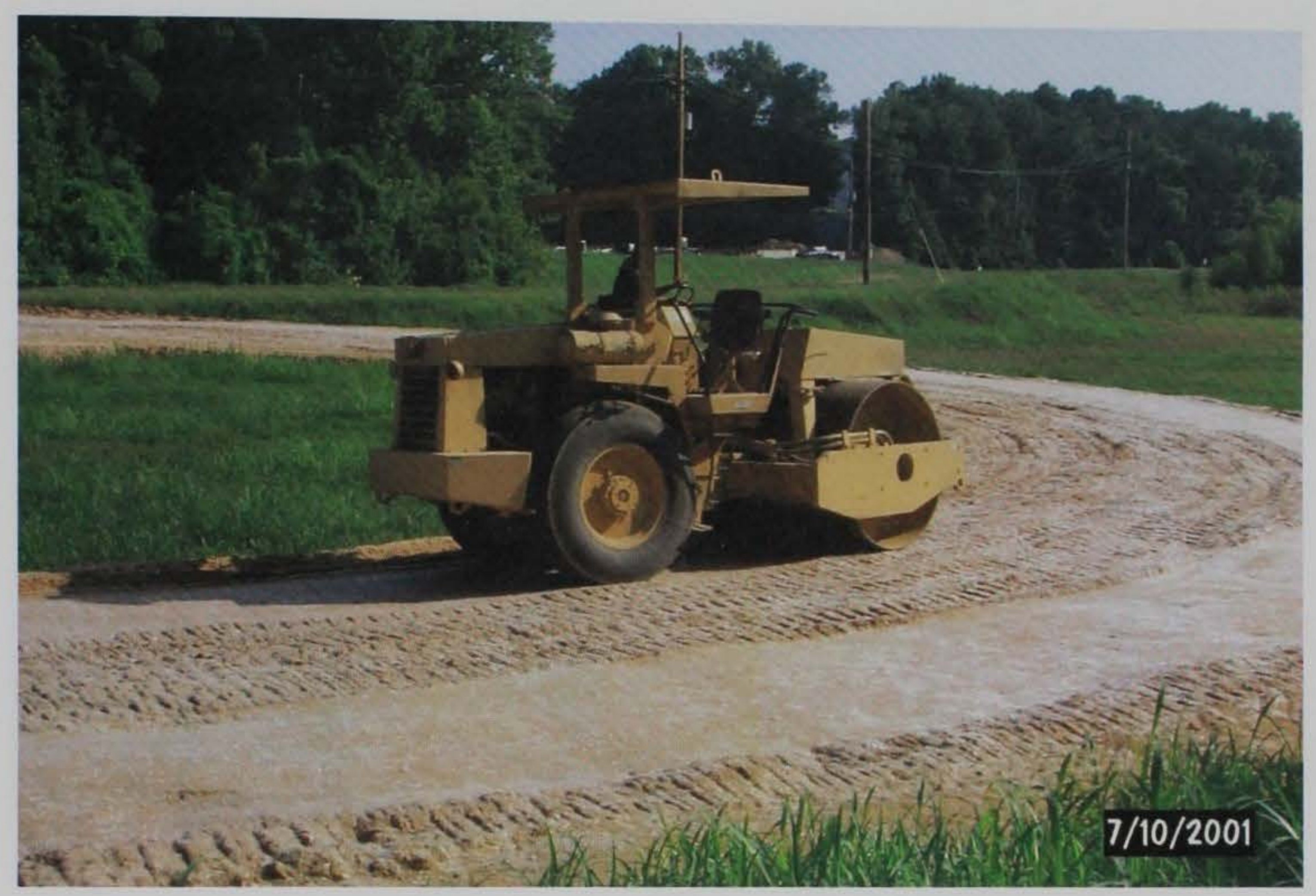

Photo 73. Compaction of the sand-geofiber item

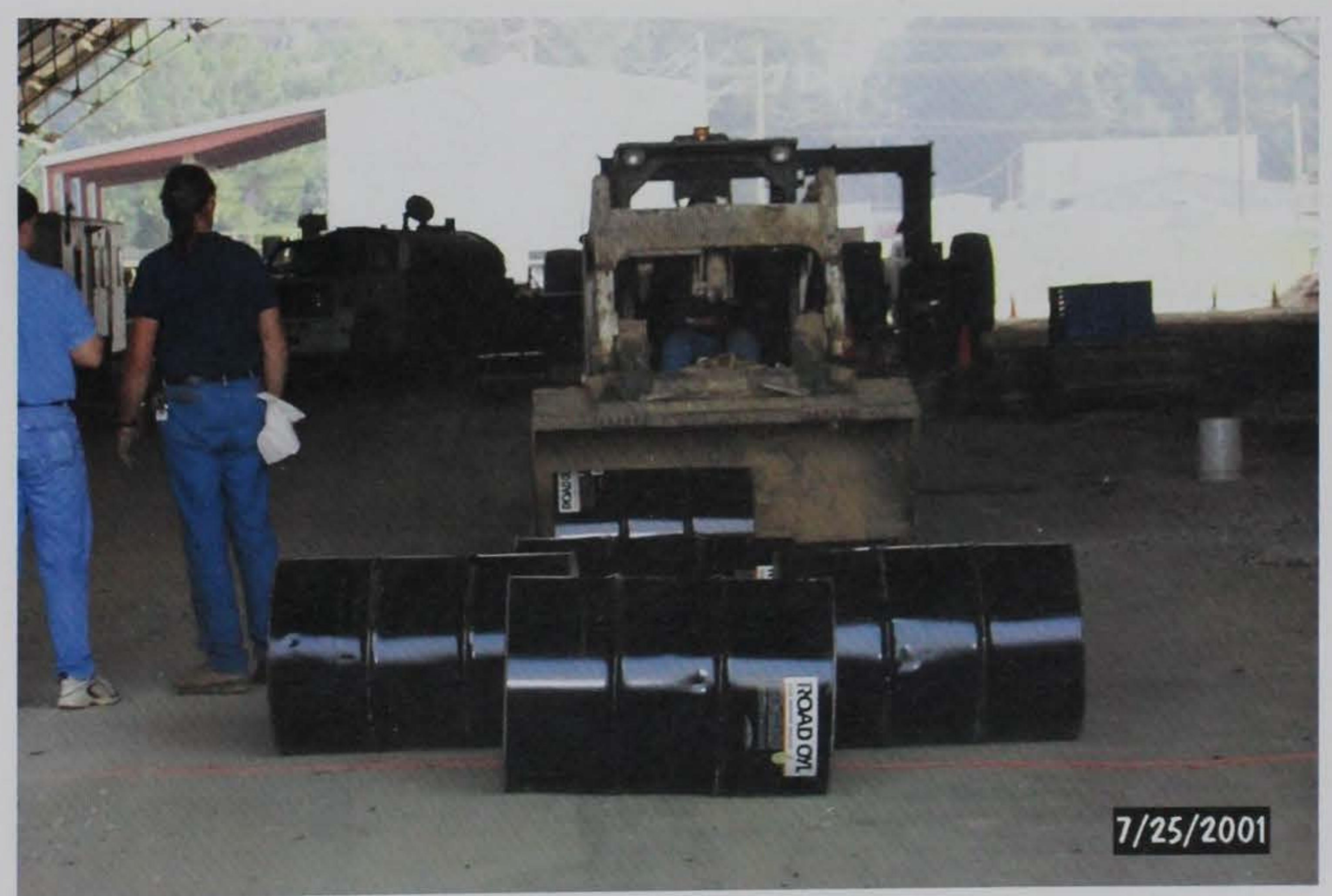

Photo 74. Shaking of Road Oyl drums 


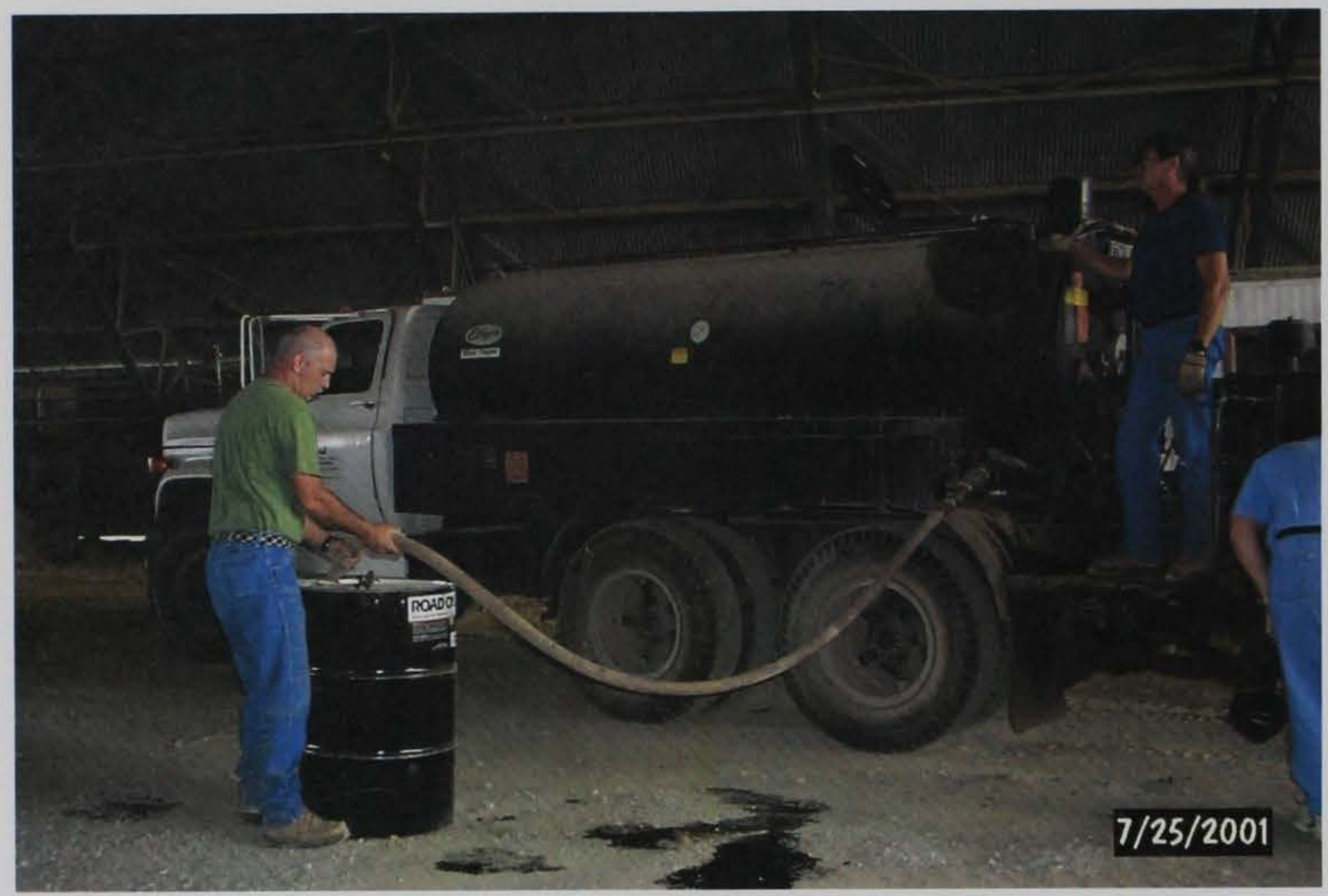

Photo 75. Pumping the Road Oyl into the asphalt distributor tank

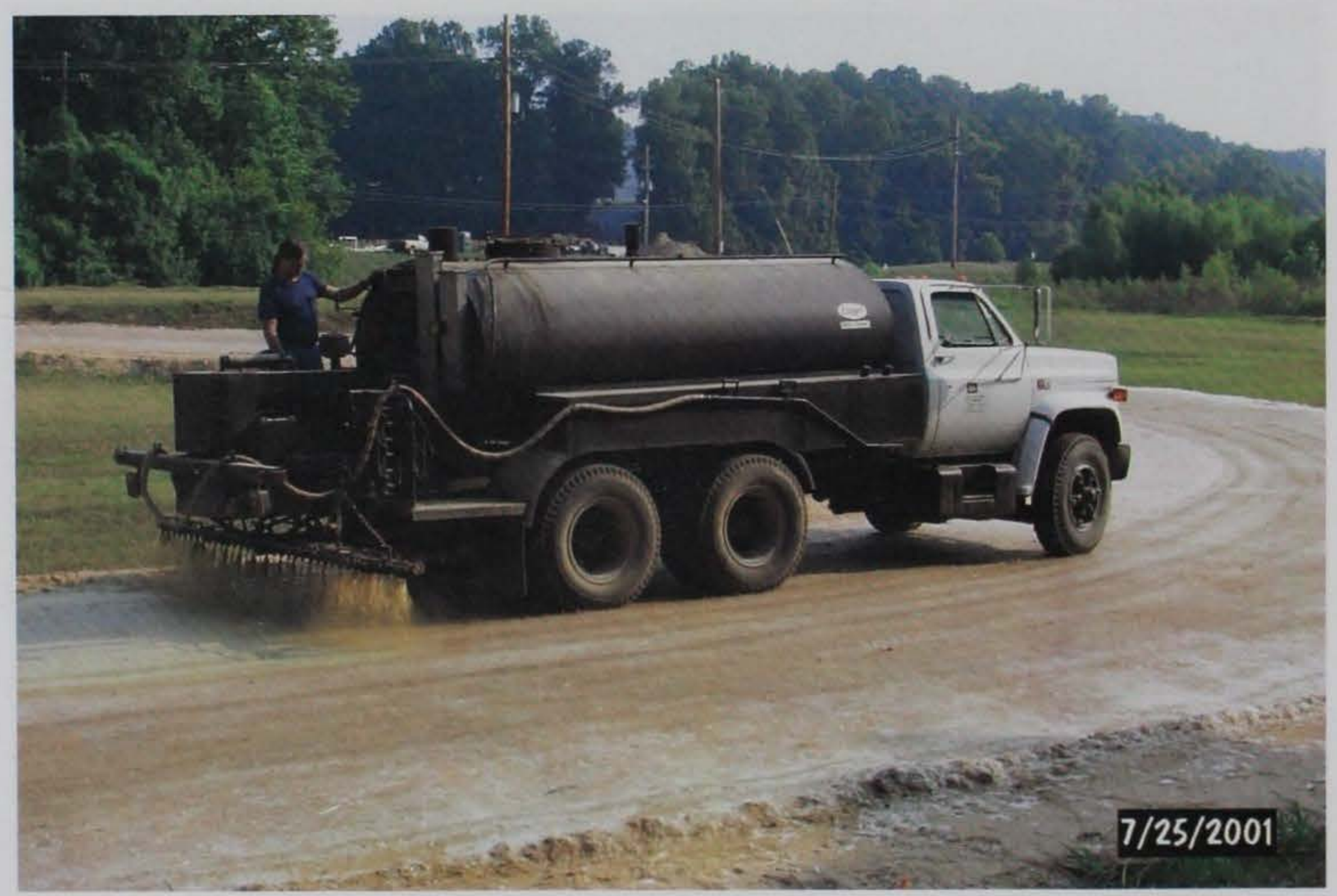

Photo 76. Spraying Road Oyl over the sand-geofiber 


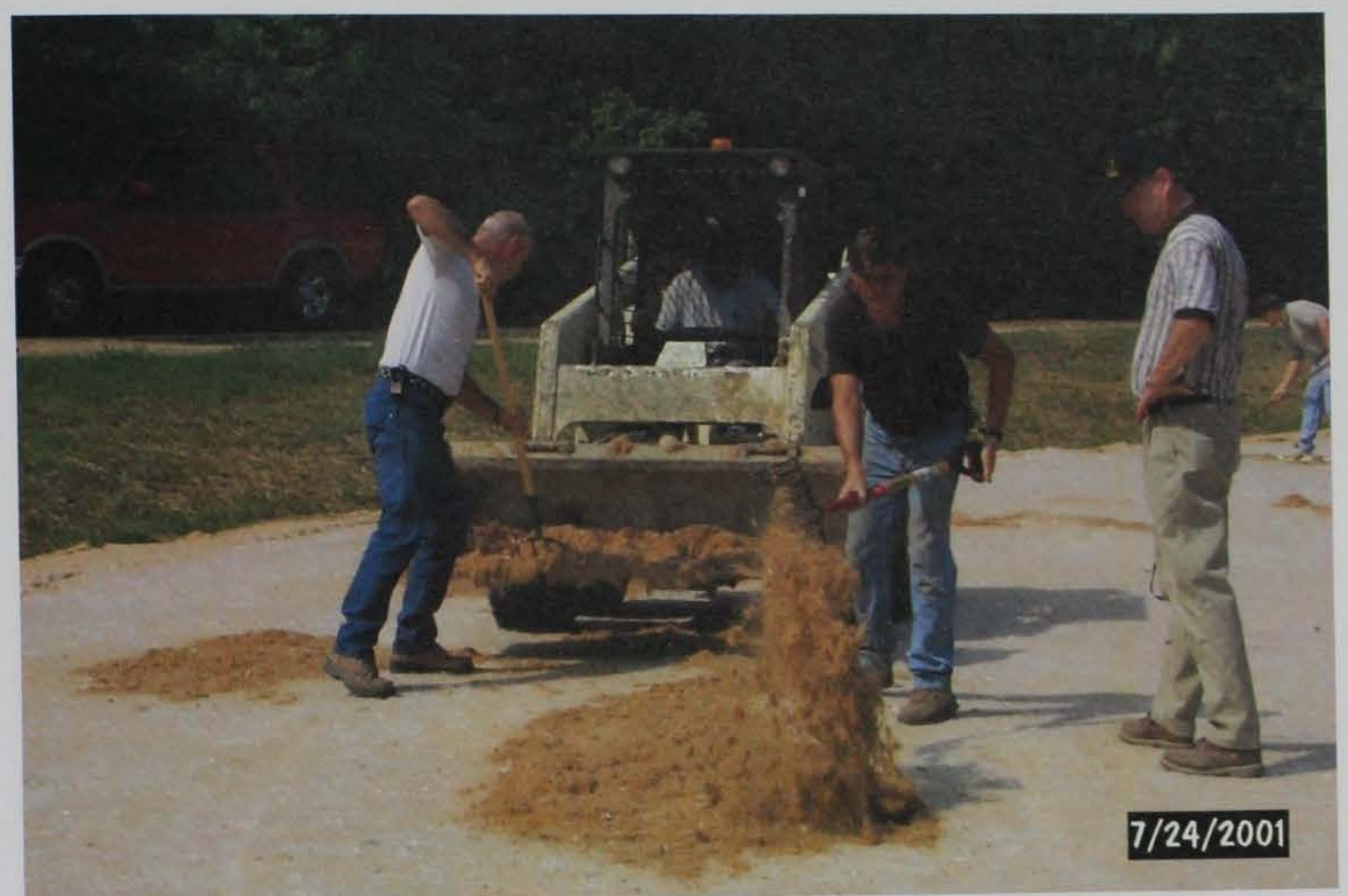

Photo 77. Patching with sand-geofibers

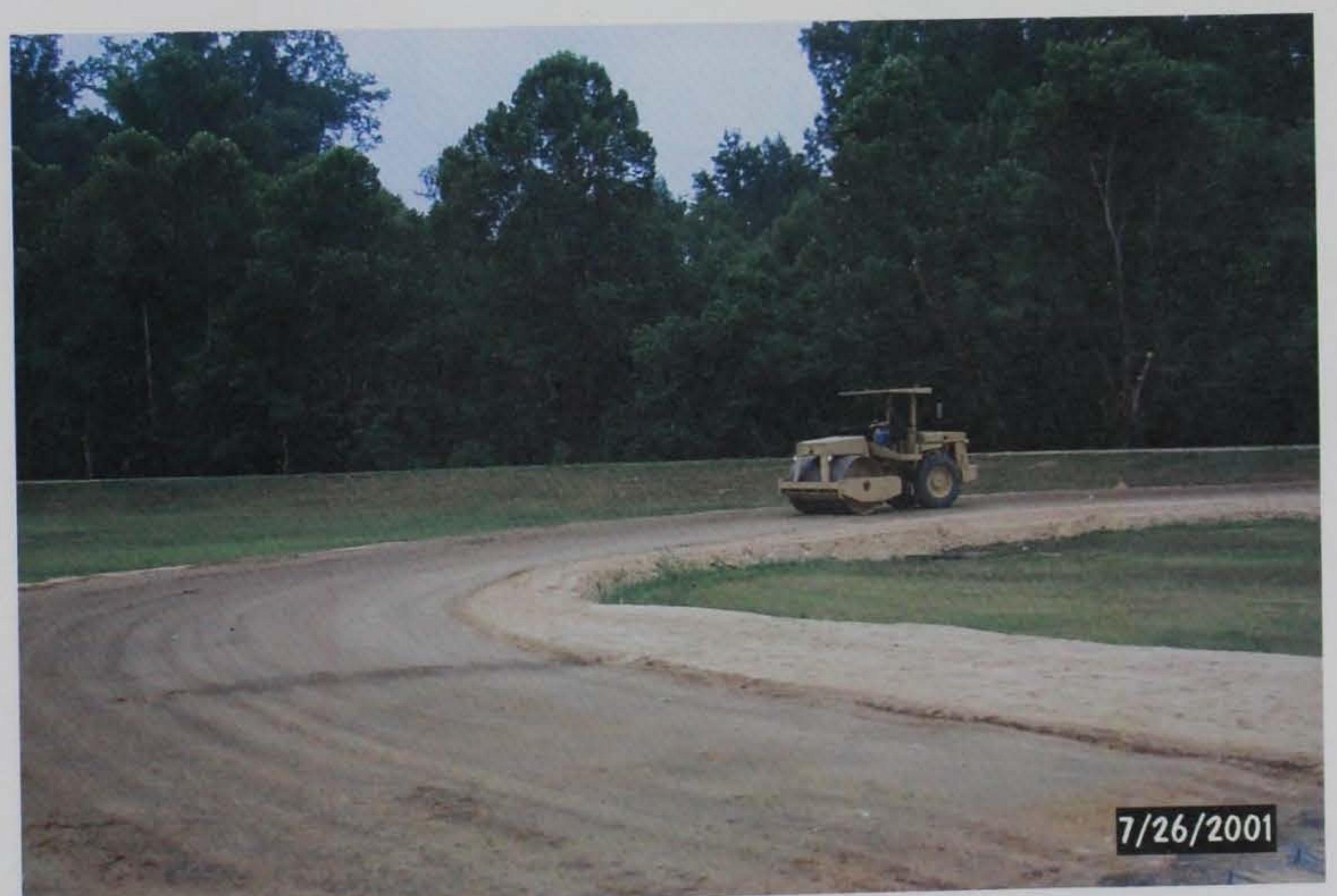

Photo 78. Compaction to seal the sand-geofiber surface 


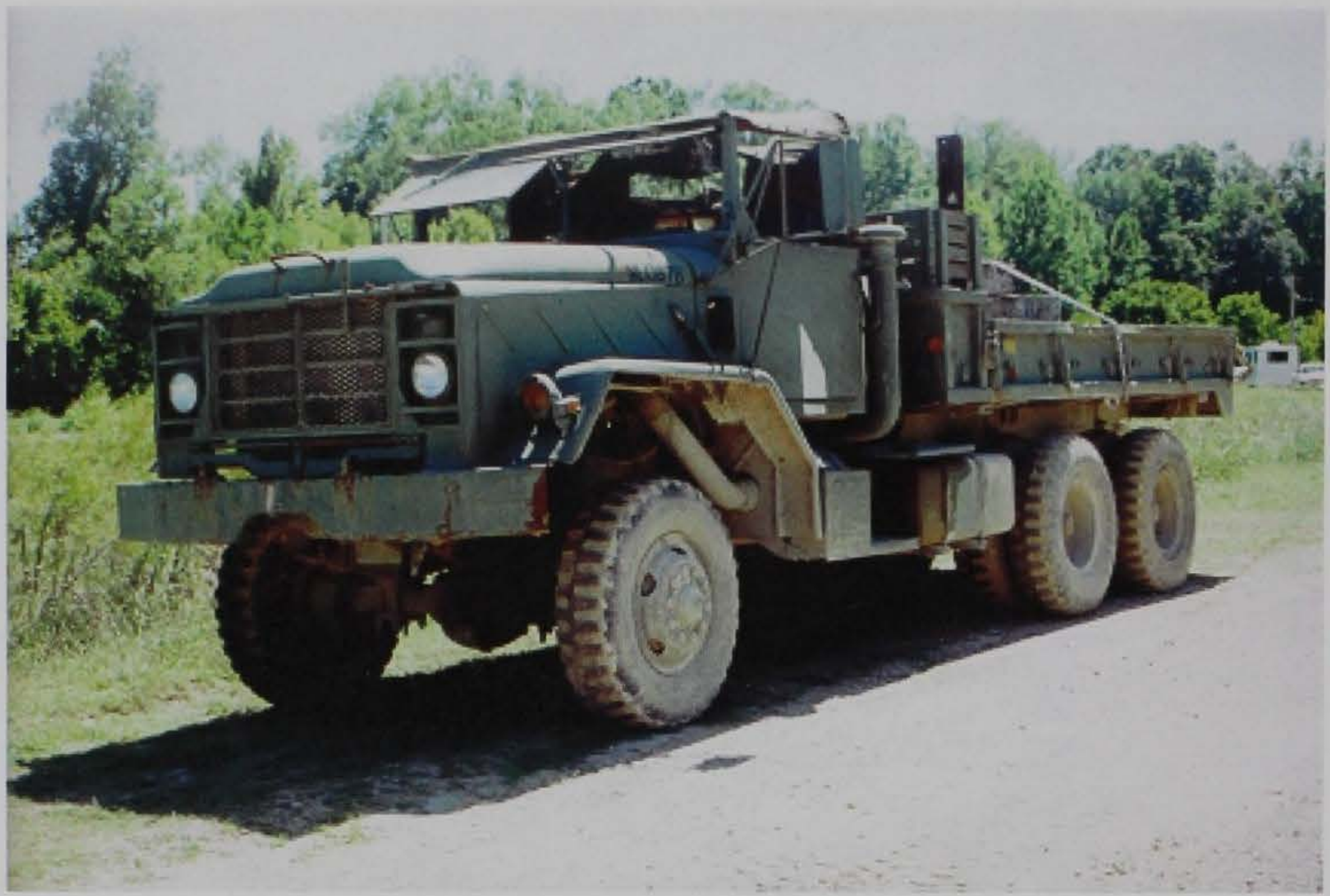

Photo 79. M923 5-ton military truck

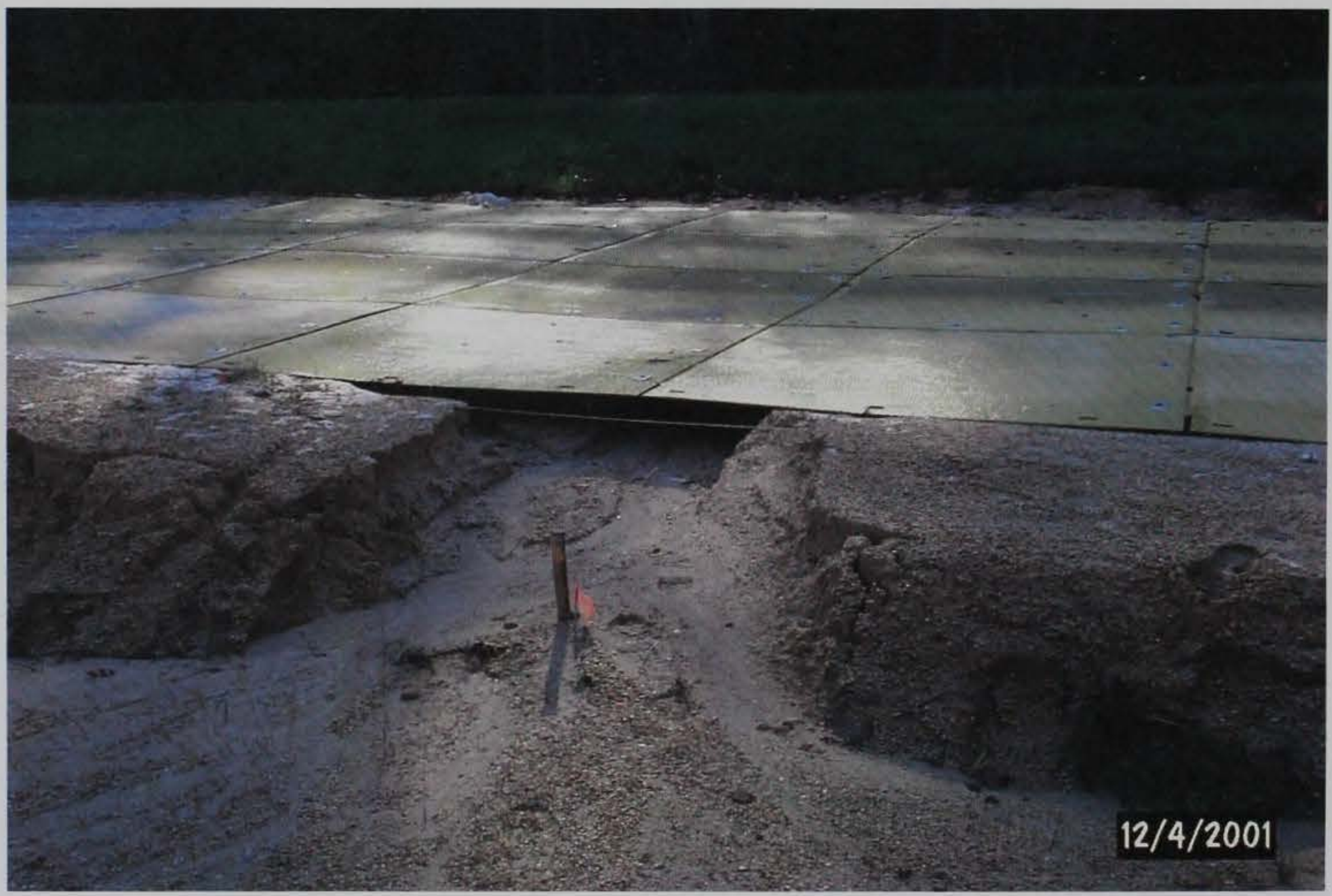

Photo 80 . Shoulder's erosion due to heavy rains 


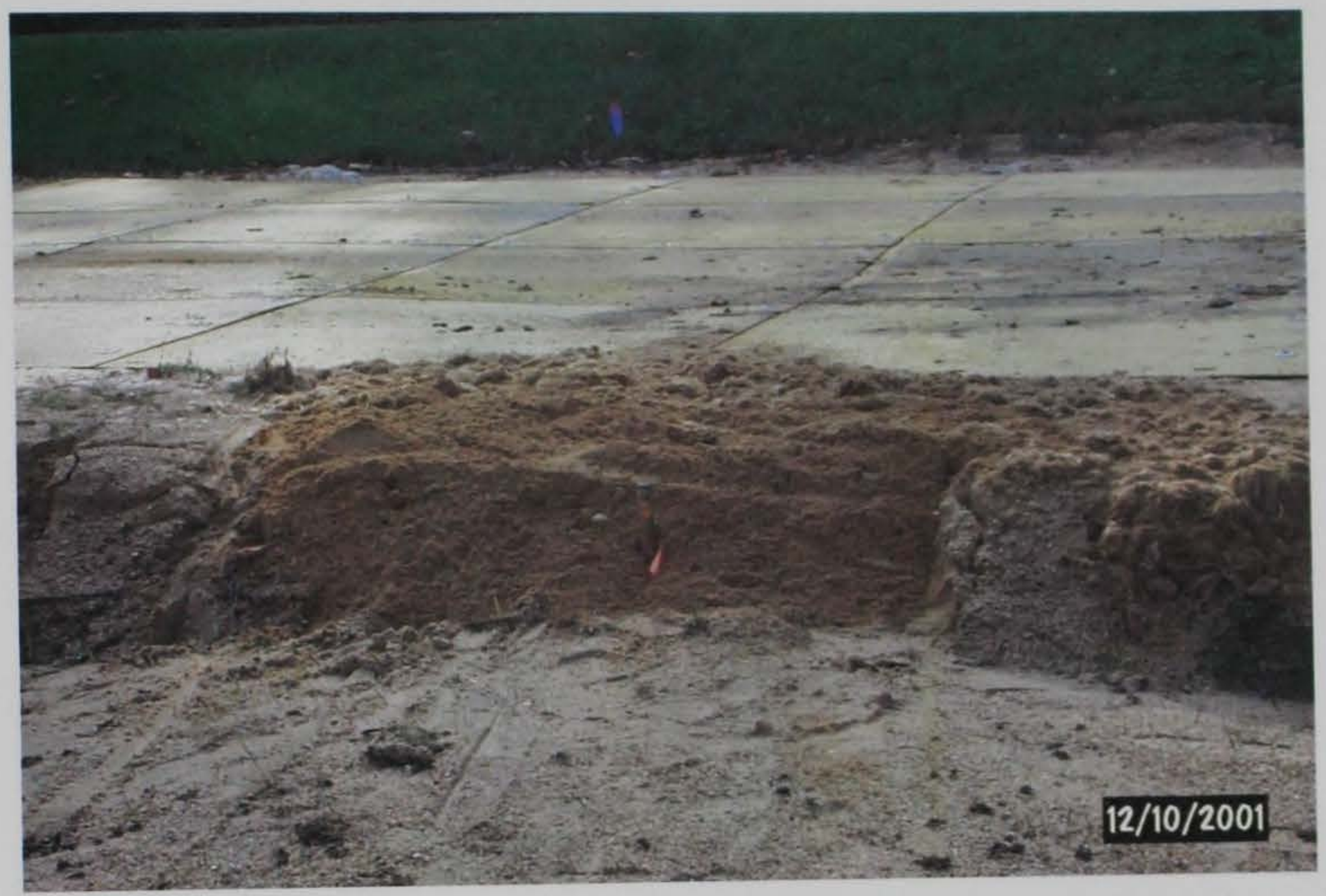

Photo 81. Repair shoulder with sand-geofiber

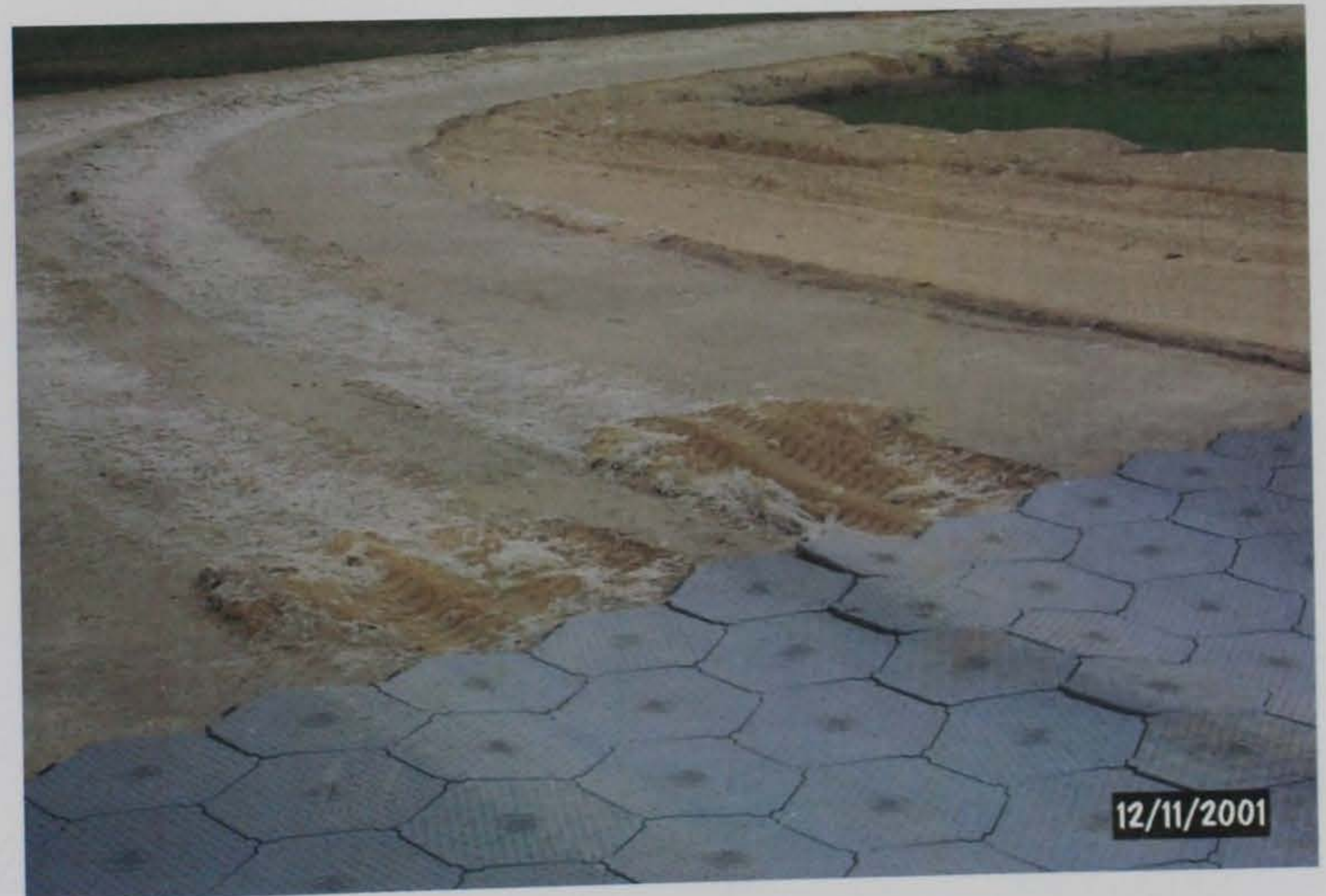

Photo 82. Deterioration in the transition zone 


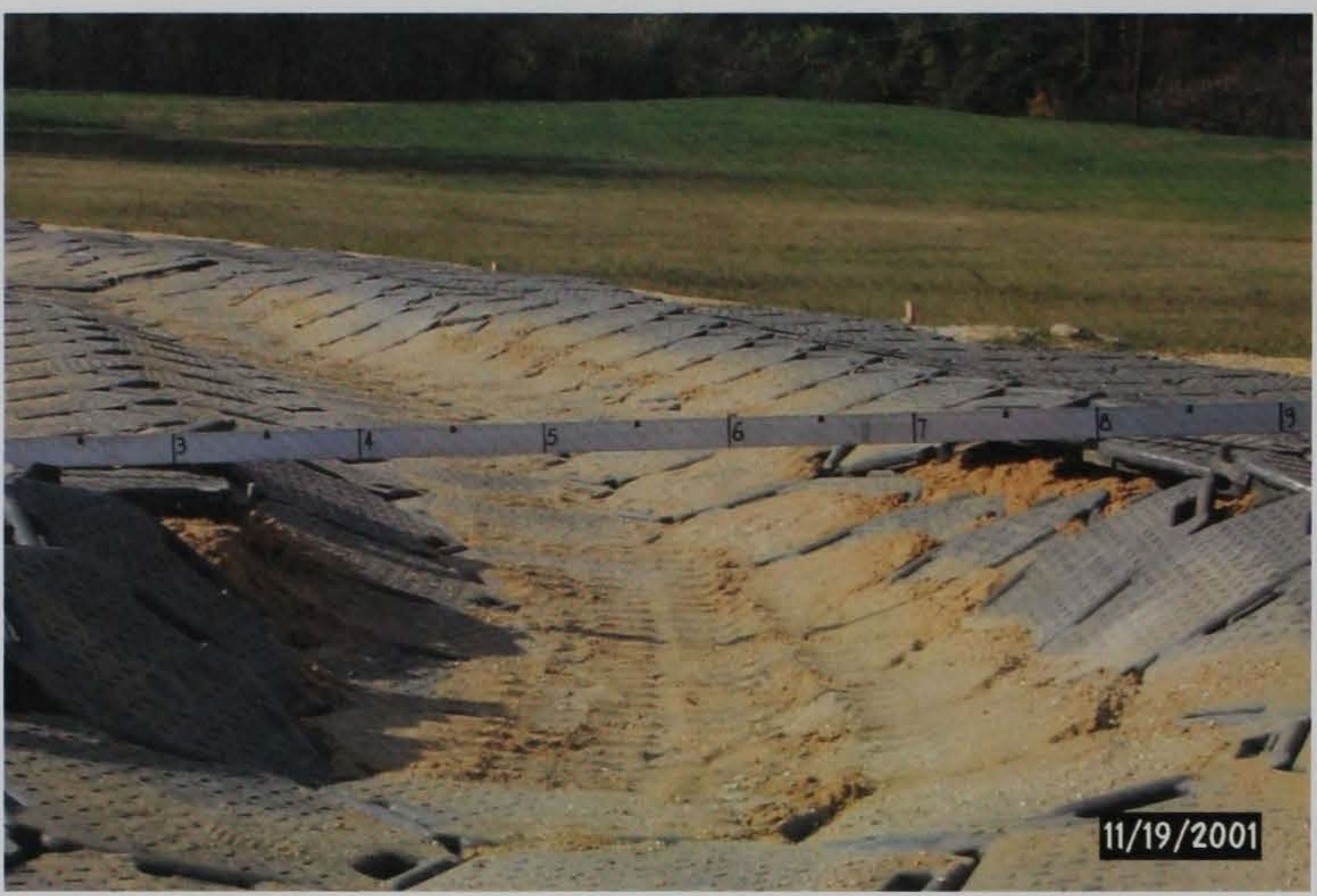

Photo 83. Rut depth measurement on Allround hexagonal mat section after 165 passes

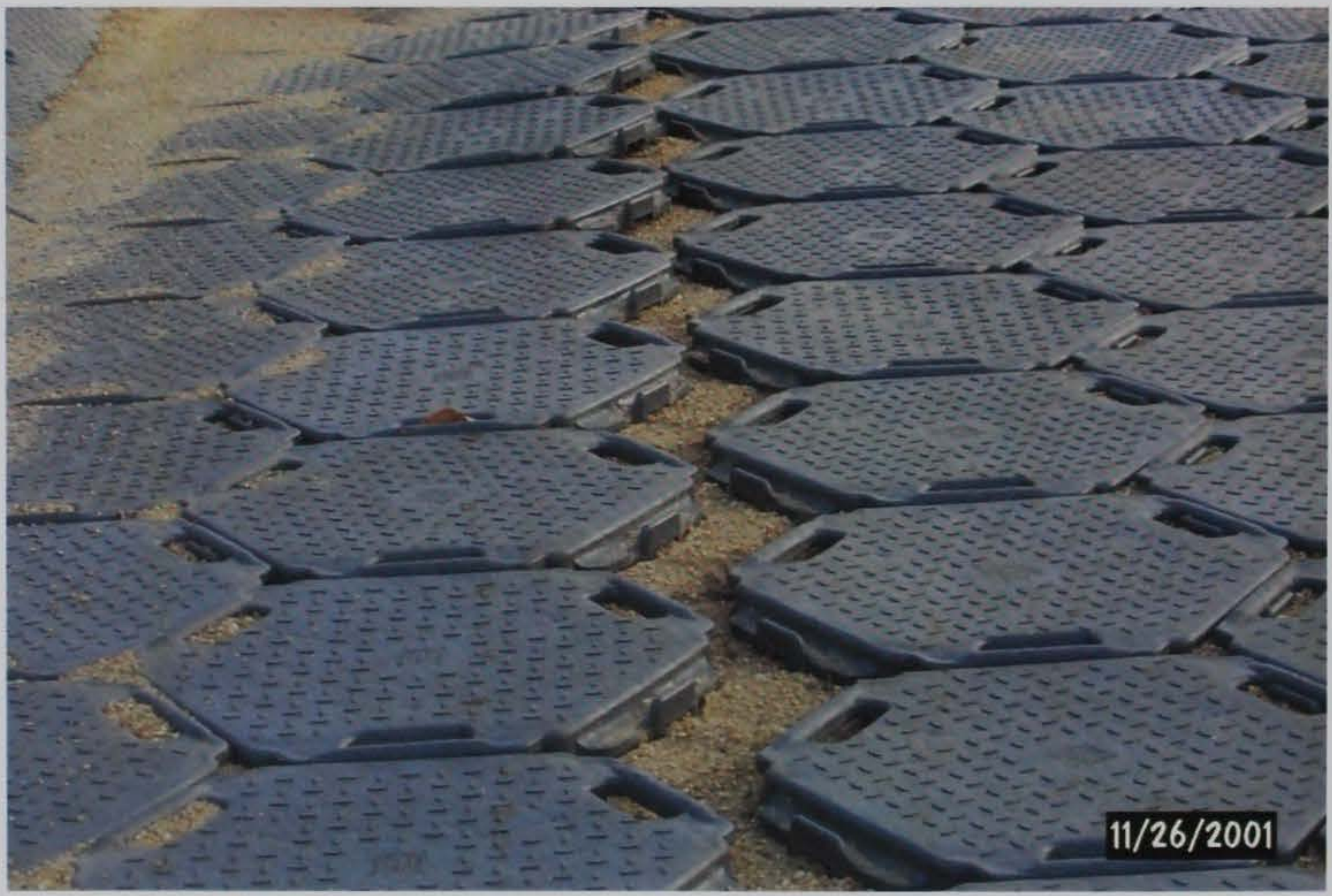

Photo 84. Allround hexagonal mat unzipped after 165 passes 


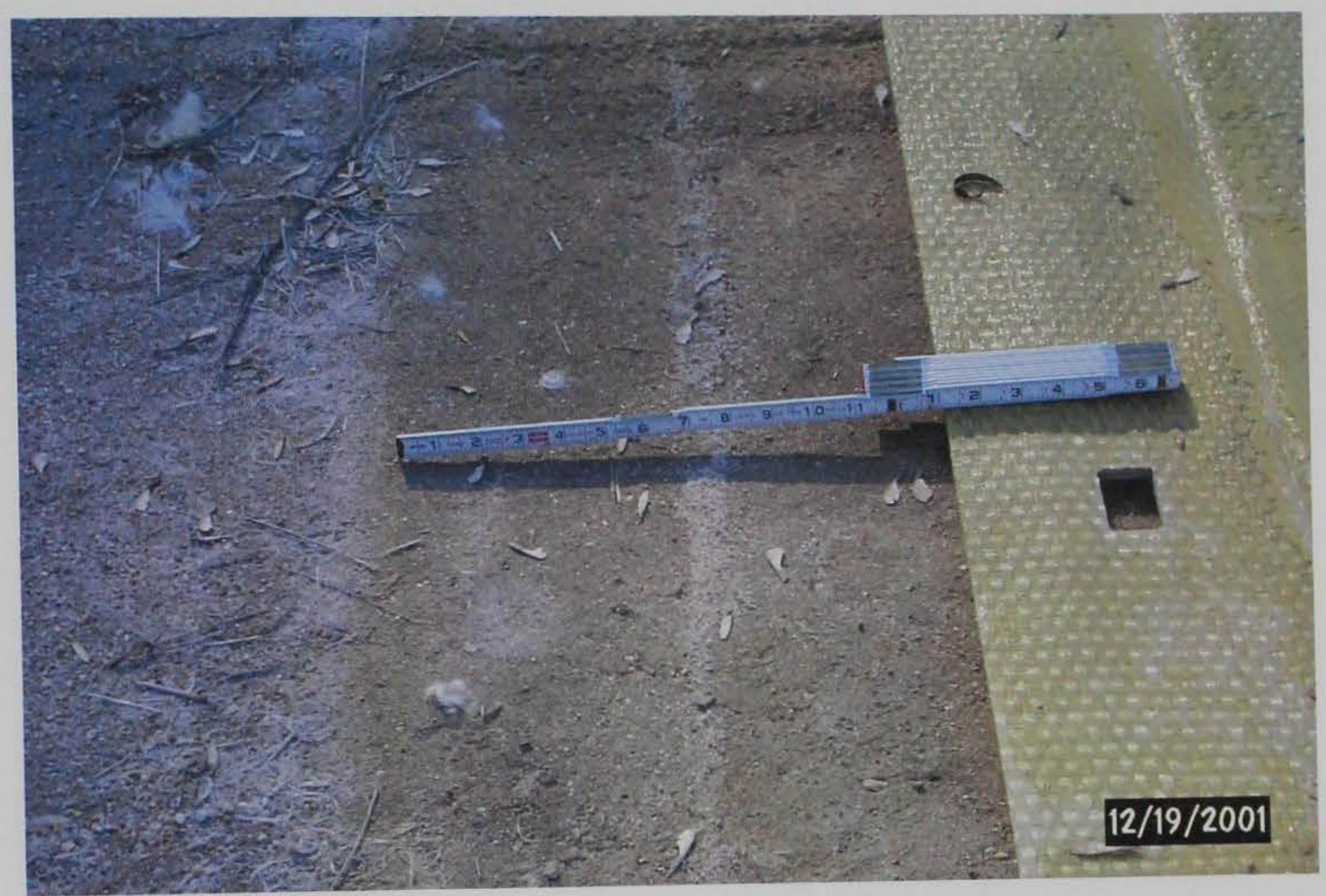

Photo 85. MP mat straight section moved $1 \mathrm{ft}$ toward traffic direction after 500 passes

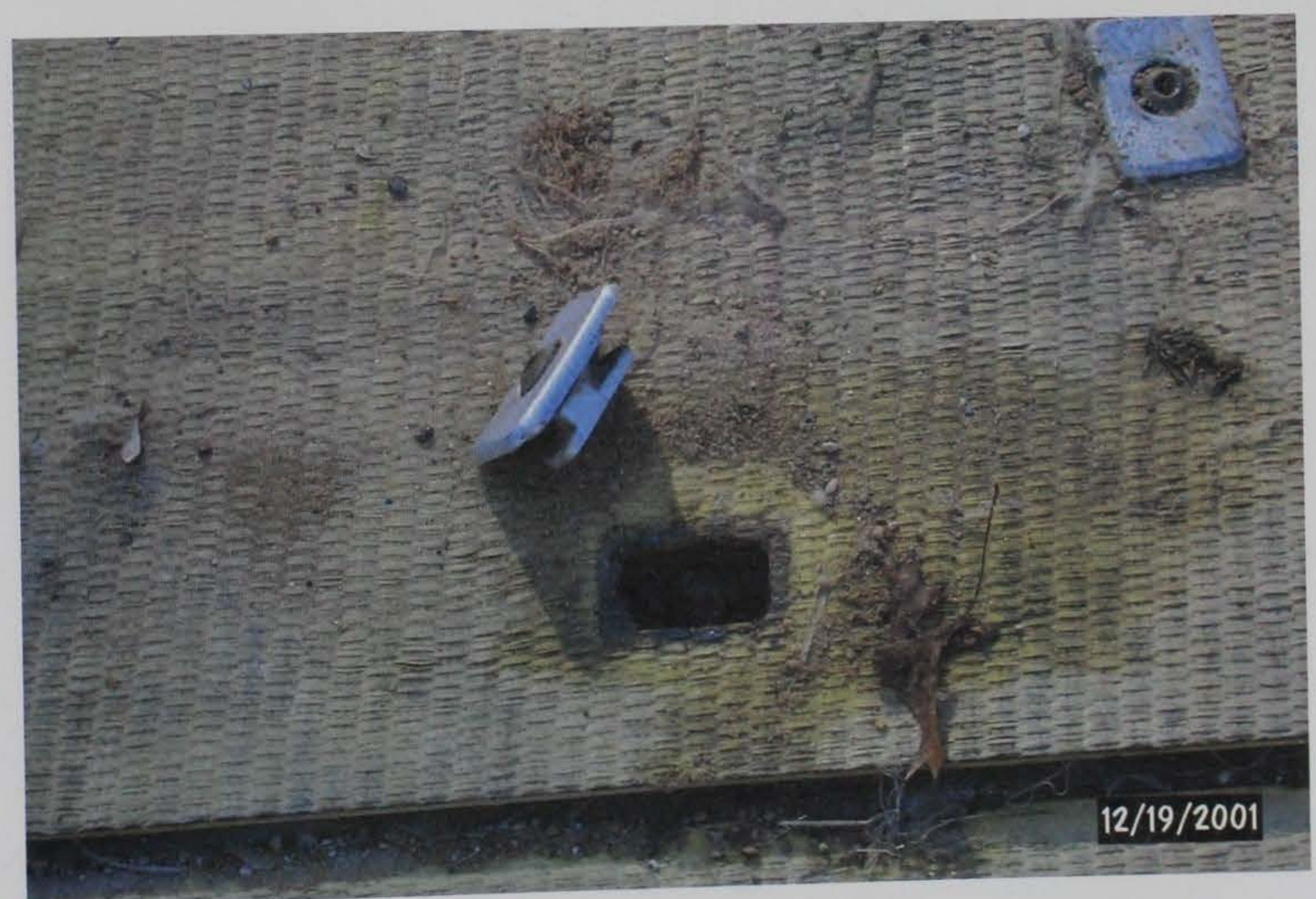

Photo 86. MP mat straight section connector pin loose after 500 passes 


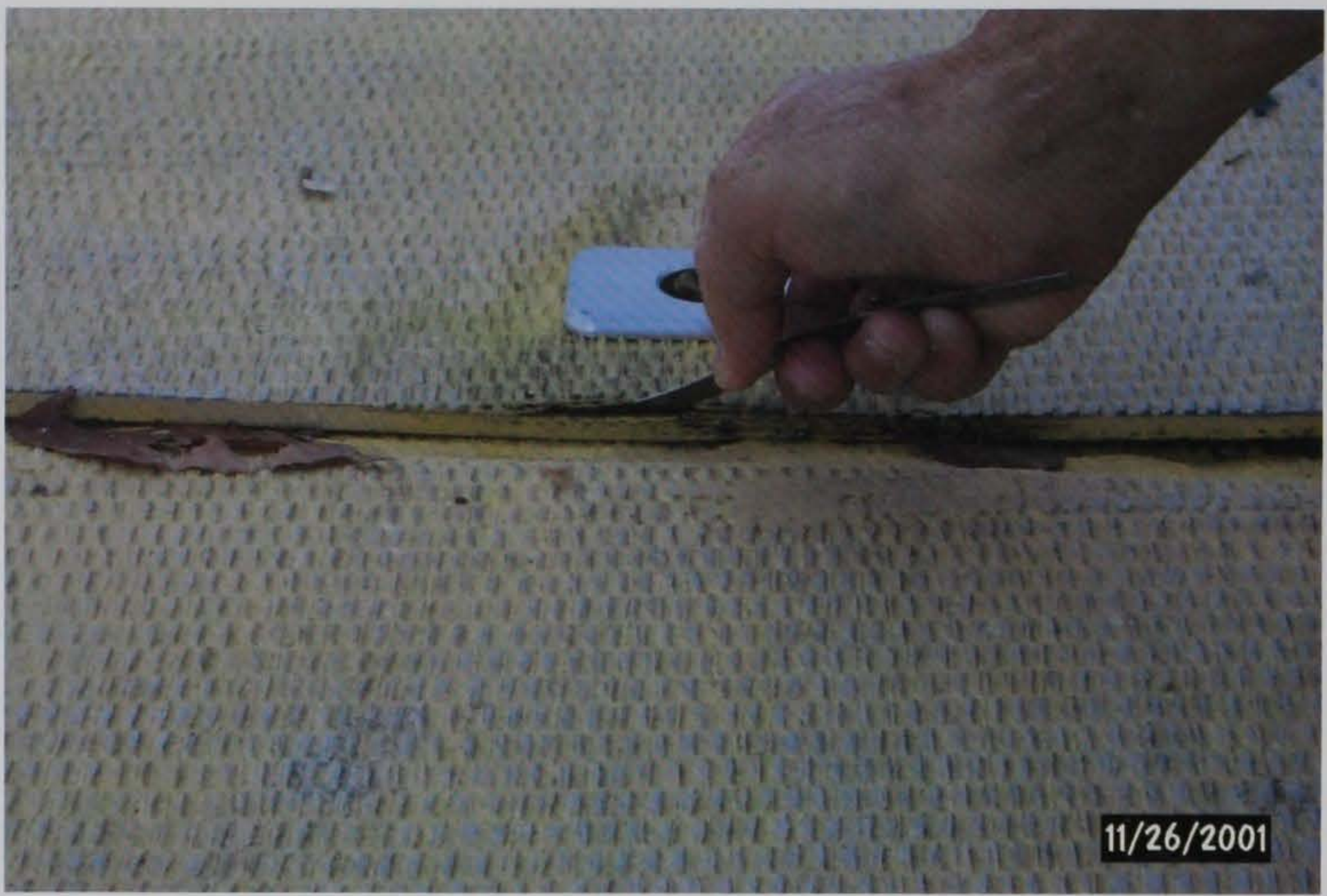

Photo 87. MP mat straight section edge delamination after 165 passes

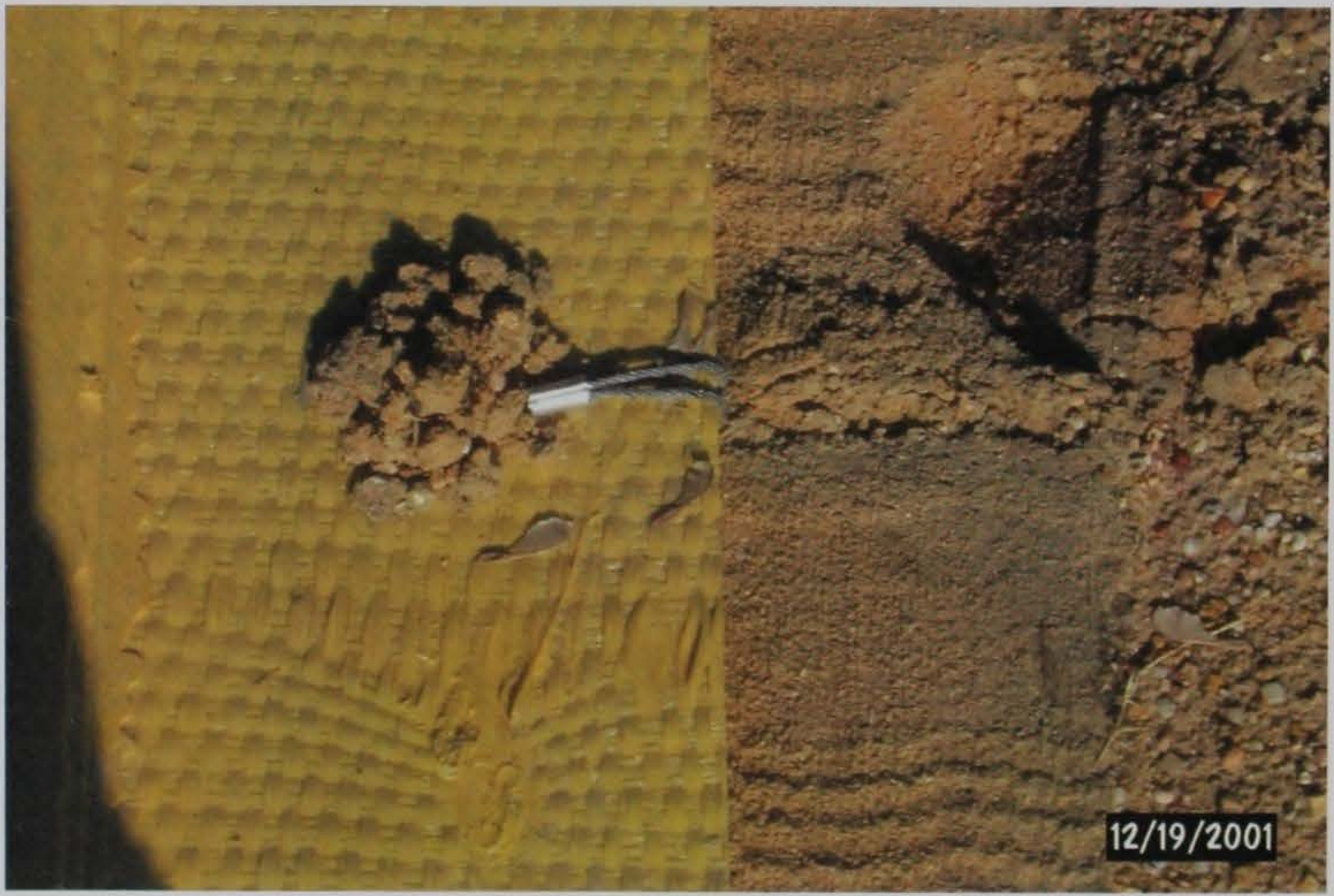

Photo 88. MP mat anchor after stretching the cable after 165 passes 


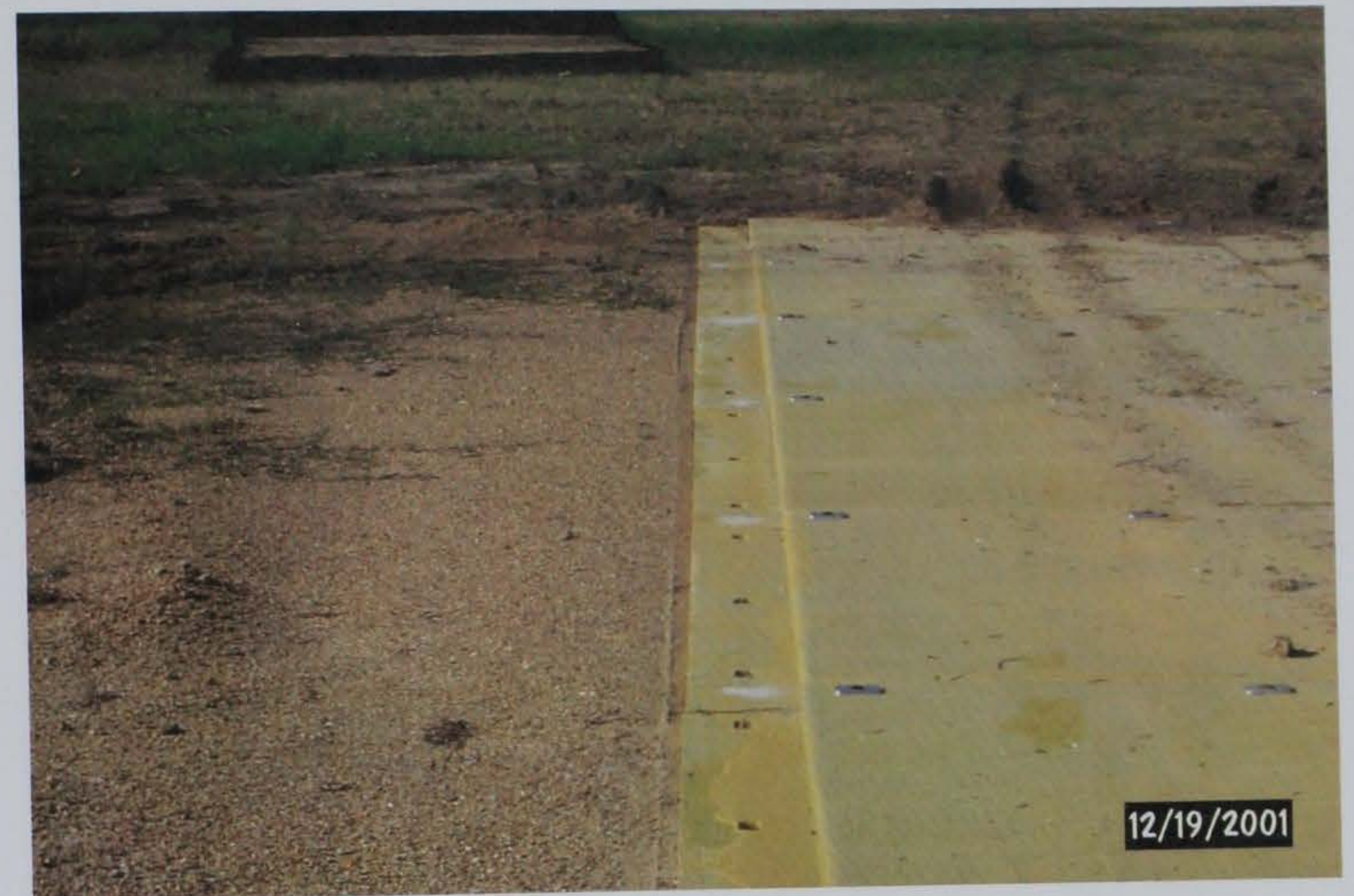

Photo 89. MP mat 50 -ft radius curve moved 2 in. toward traffic direction after 500 passes

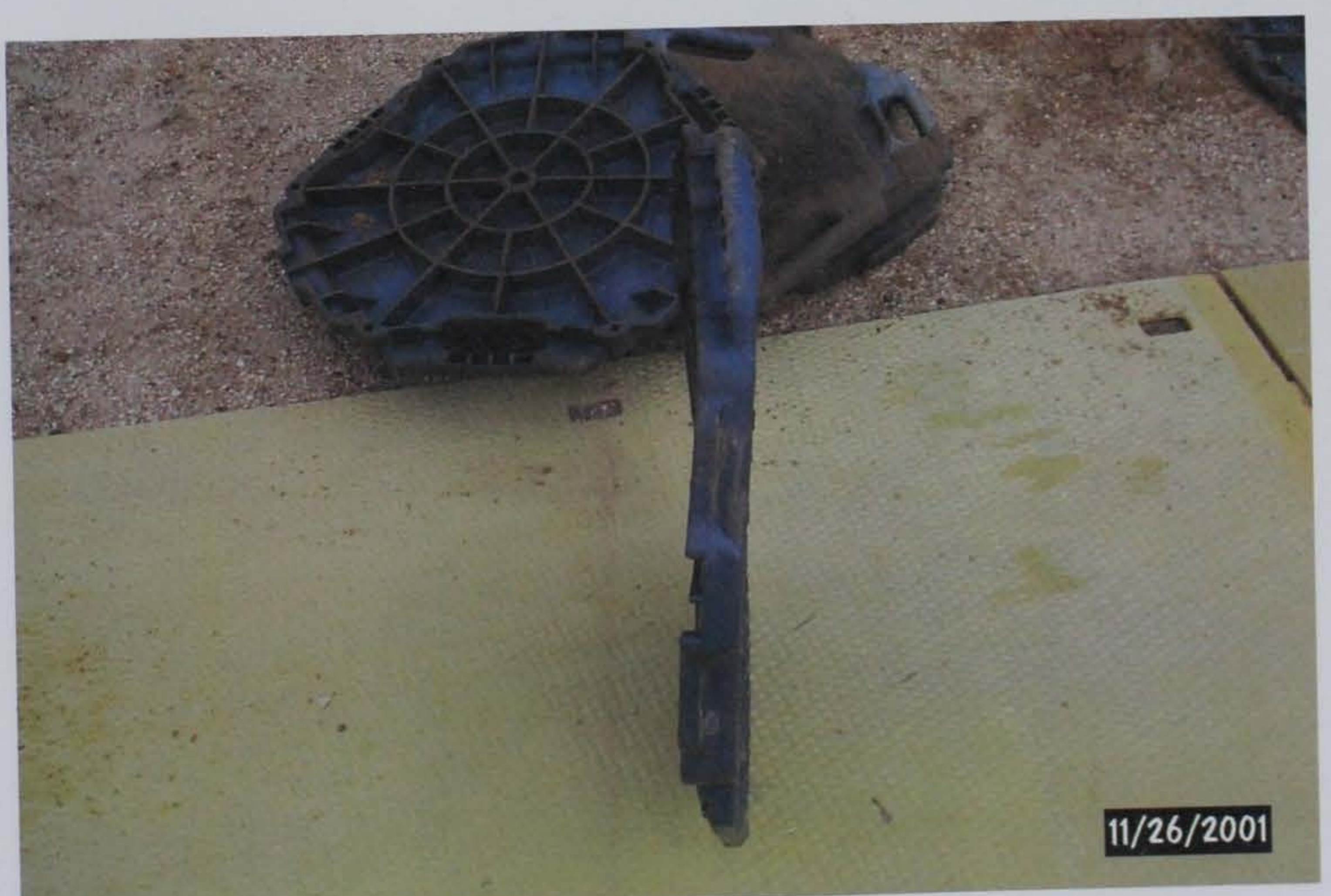

Photo 90. Allround hexagonal plastic mat bent after 165 passes 


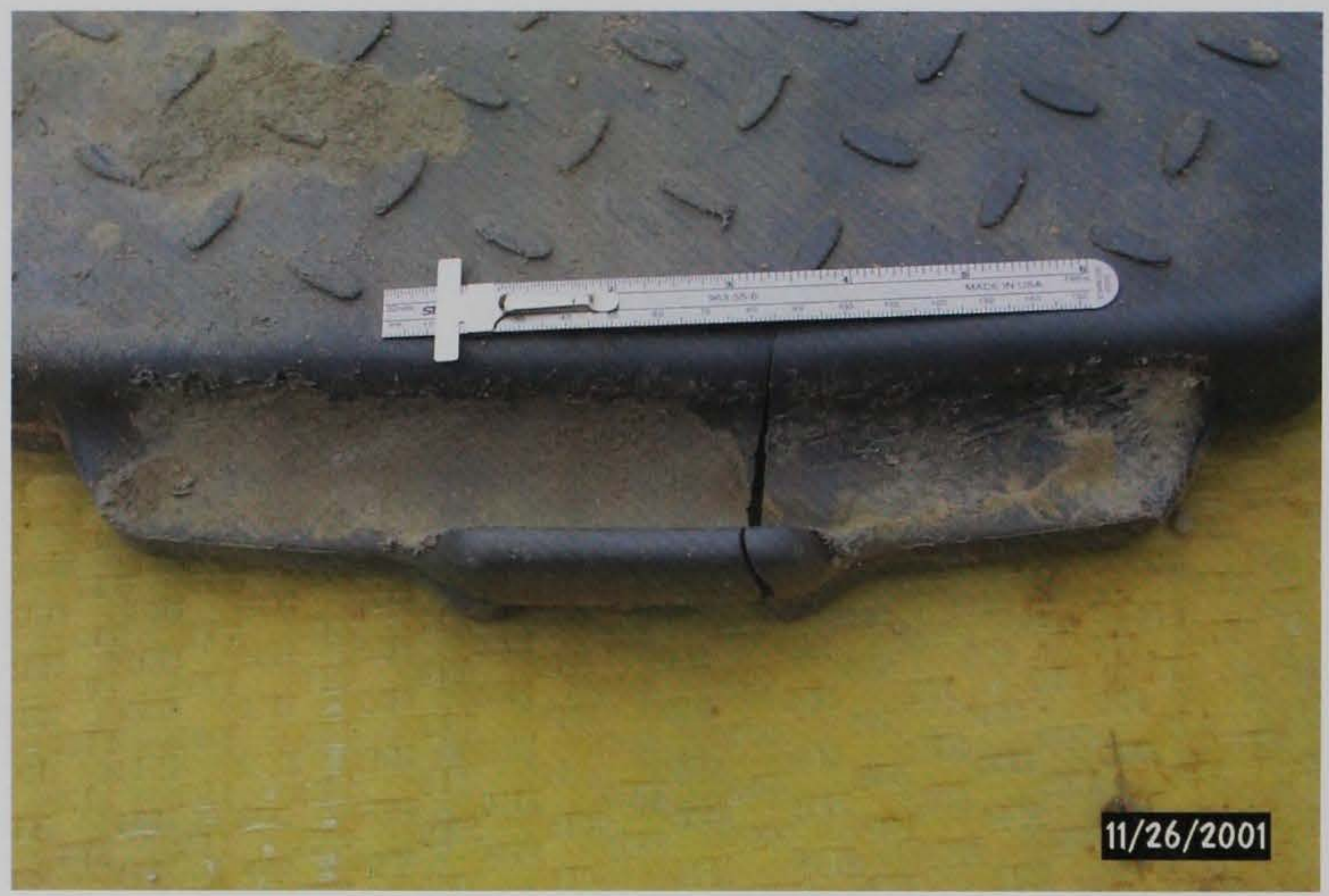

Photo 91. Allround hexagonal plastic mat broke at connector after 165 passes

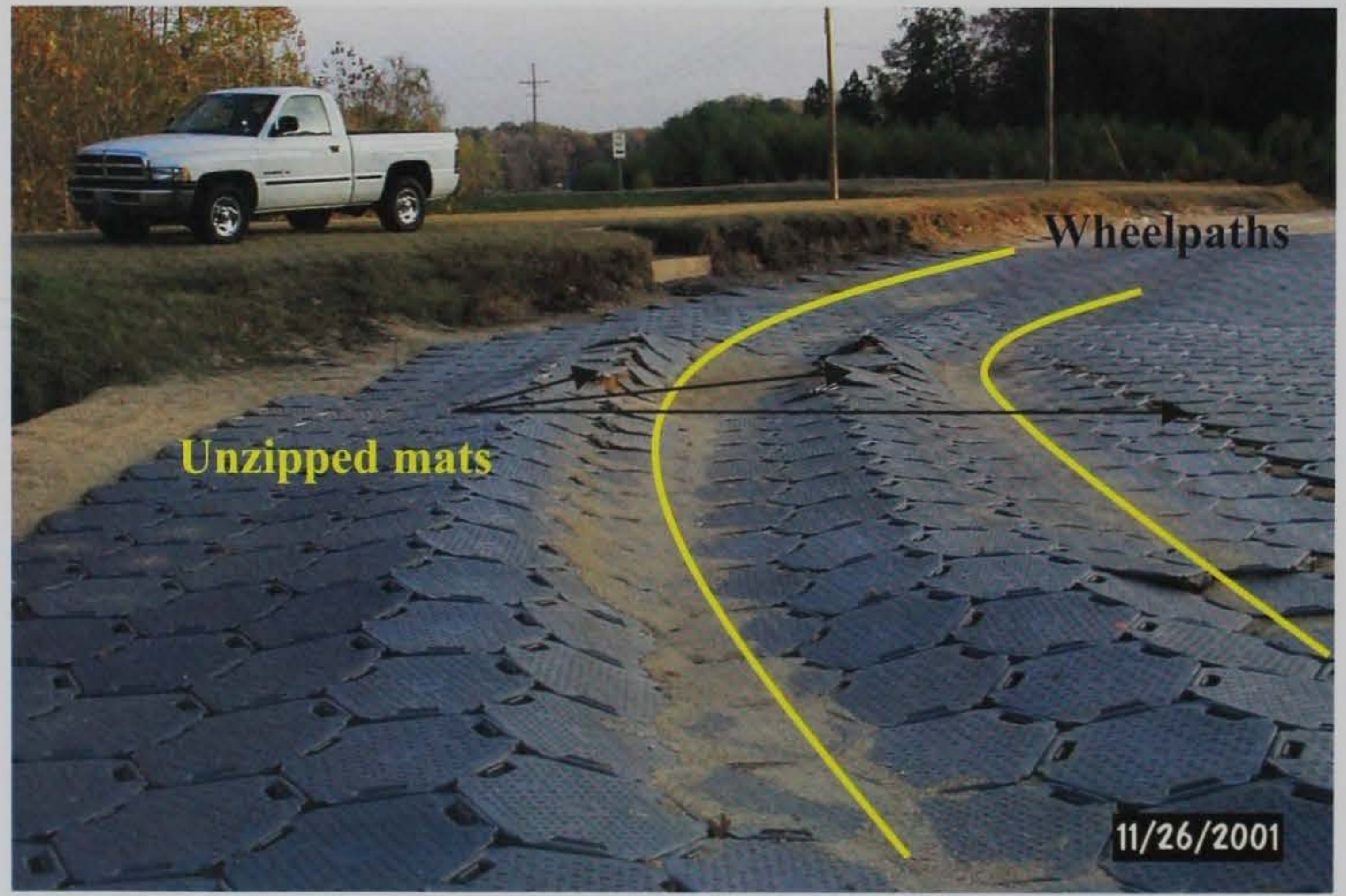

Photo 92. Allround hexagonal mat unzipped after 165 passes 


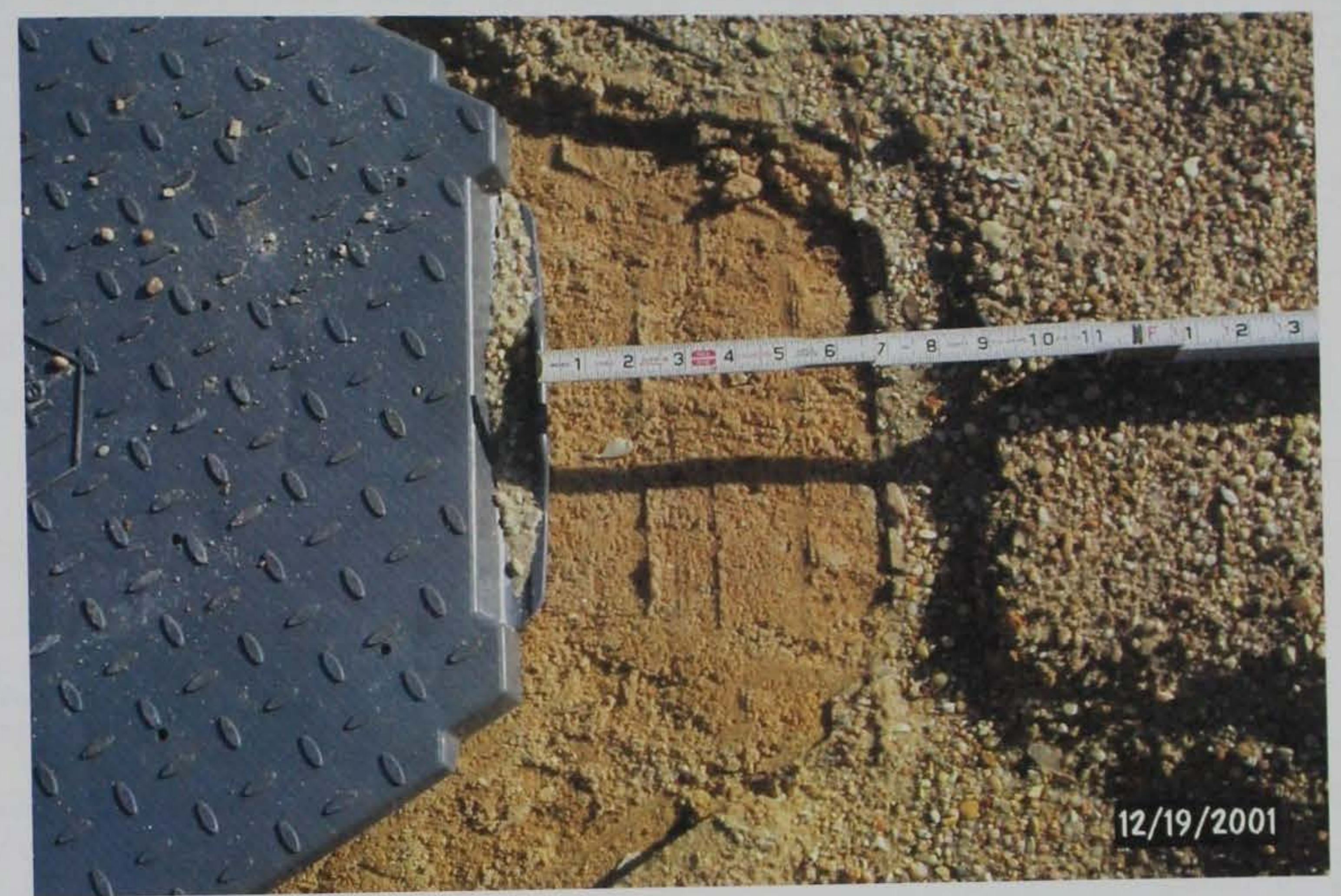

Photo 93. Special hexagonal mat moved 7 in. after 500 passes

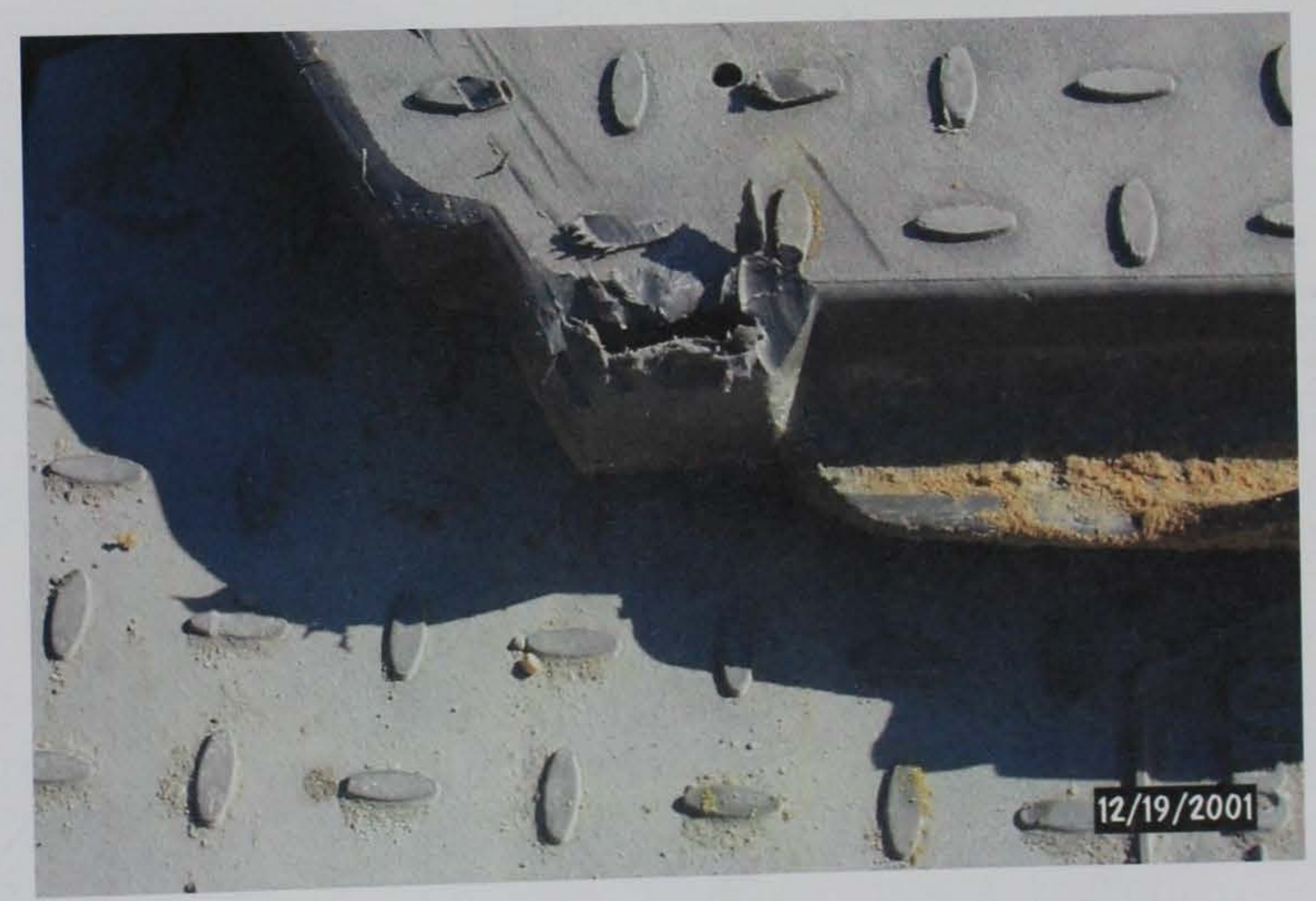

Photo 94 . Special hexagonal plastic mat broke at the corner when hit by the truck axle 


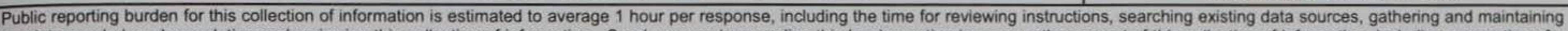

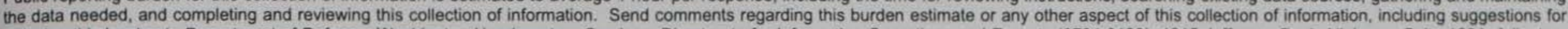

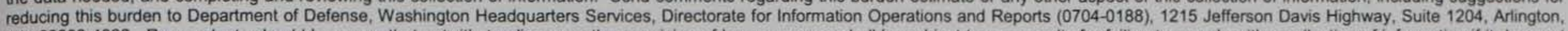

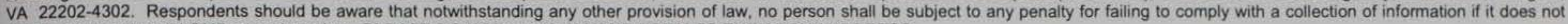
display a currently valid OMB control number. PLEASE DO NOT RETURN YOUR FORM TO THE ABOVE ADDRESS.
1. REPORT DATE (DD-MM-YYYY)
2. REPORT TYPE
3. DATES COVERED (From - To)

July 2003

Final report

4. TITLE AND SUBTITLE

Enhanced Coastal Trafficability: Road Construction Over Sandy Soils

5a. CONTRACT NUMBER

5b. GRANT NUMBER

5c. PROGRAM ELEMENT NUMBER

6. AUTHOR(S)

Rosa L. Santoni

5d. PROJECT NUMBER

5e. TASK NUMBER

5f. WORK UNIT NUMBER

8. PERFORMING ORGANIZATION REPORT NUMBER

ERDC/GSL TR-03-7

U.S. Army Engineer Research and Development Center

Geotechnical and Structures Laboratory

3909 Halls Ferry Road

Vicksburg, MS 39180-6199

9. SPONSORING / MONITORING AGENCY NAME(S) AND ADDRESS(ES)

10. SPONSOR/MONITOR'S ACRONYM(S)

U.S. Army Corps of Engineers

Washington, DC 20314-1000

11. SPONSOR/MONITOR'S REPORT NUMBER(S)

\section{DISTRIBUTION / AVAILABILITY STATEMENT}

Approved for public release; distribution is unlimited.

13. SUPPLEMENTARY NOTES

\section{ABSTRACT}

This report describes field experiments conducted using Multi-Purpose (MP) mats, hexagonal plastic mats (Allround and Special), and sand-geofiber stabilization for expedient road construction over sandy soils. Field sections were constructed and trafficked to evaluate construction procedures, design parameters, and their performance over loose sand conditions. Experiment items were trafficked with 500 passes of a $41,600-1 \mathrm{~b}, 5$-ton military truck. Field experiment results indicated that MP mats and sand-geofiber stabilization are capable of providing structural support to military traffic over sandy soil conditions on straight and curved sections. The Allround and Special hexagonal plastic mats are capable of withstanding limited traffic, but they are unsuitable for supporting substantial amounts of military traffic on curved sections over the very loose sand conditions used in this experiment.

\section{SUBJECT TERMS}

Contingency pavements

Expedient roads

16. SECURITY CLASSIFICATION OF:

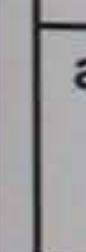

\section{a.}

Expedient surfacings

Hexagonal plastic mats

Logistics-over-the-shore

\begin{tabular}{l|l|l}
\hline a. REPORT & b. ABSTRACT & c. THIS PAGE \\
UNCLASSIFIED & UNCLASSIFIED & UNCLASSIFIED
\end{tabular}

17. LIMITATION OF ABSTRACT
Multi-purpose mats

Road construction
18. NUMBER OF PAGES

111 19a. NAME OF RESPONSIBLE PERSON

19b. TELEPHONE NUMBER (include area code) 